Jacek Pyżalski, Aldona Zdrodowska, Łukasz Tomczyk, Katarzyna Abramczuk

\title{
Polskie badanie
}
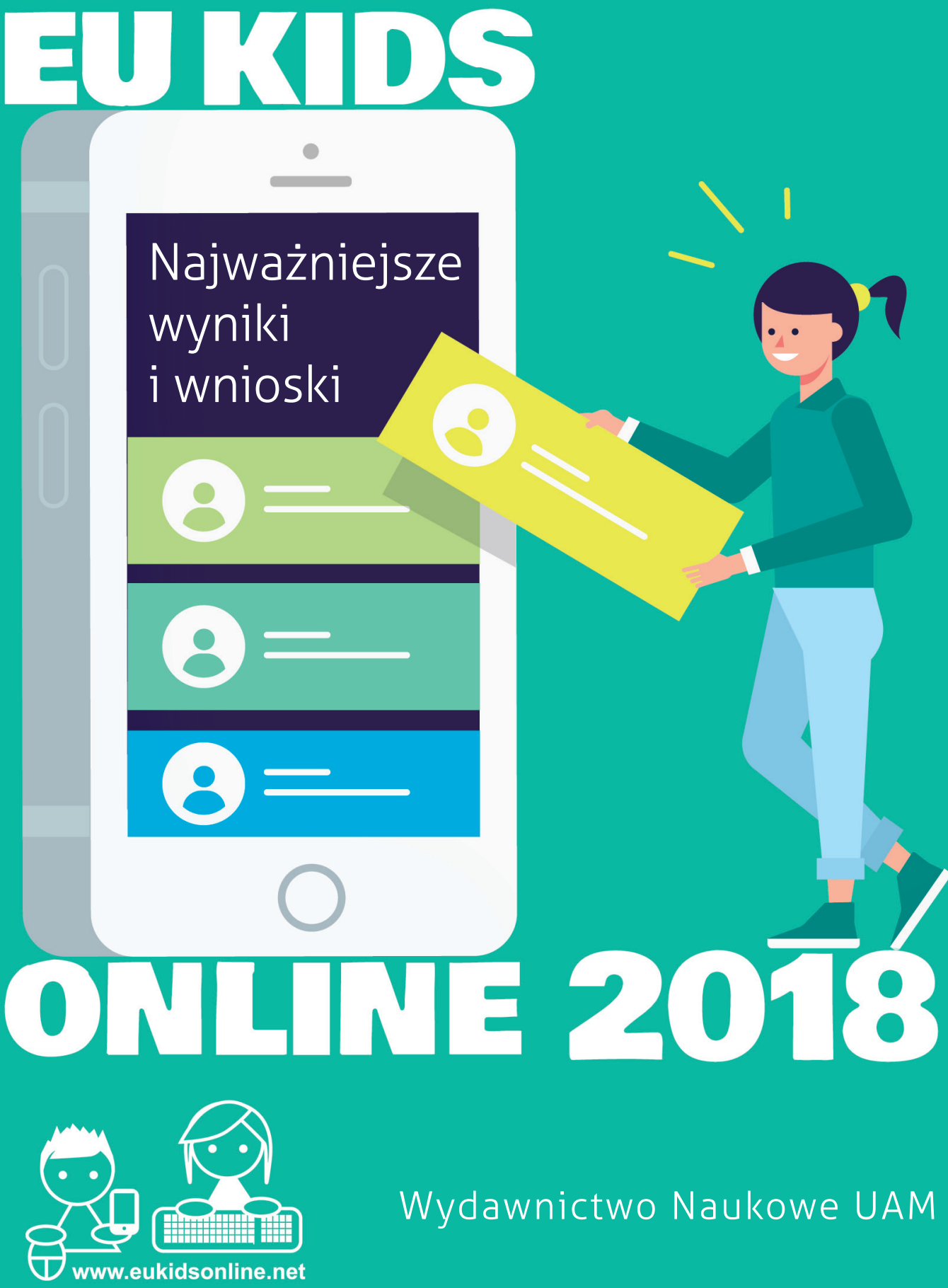

Wydawnictwo Naukowe UAM 
Polskie badanie EU Kids Online 2018 

UNIWERSYTET IM. ADAMA MICKIEWICZA W POZNANIU

Jacek Pyżalski

Aldona Zdrodowska

Łukasz Tomczyk

Katarzyna Abramczuk

\section{Polskie badanie EU Kids Online 2018}

Najważniejsze wyniki i wnioski

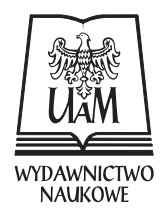

POZNAŃ 2019 
Recenzent: dr hab. Piotr Plichta

dr hab. Natalia Walter

Badanie i wydanie publikacji zrealizowano w partnerstwie z Fundacją Orange

(C) Jacek Pyżalski, Aldona Zdrodowska, Łukasz Tomczyk, Katarzyna Abramczuk 2019

This edition (c) Uniwersytet im. Adama Mickiewicza w Poznaniu,

Wydawnictwo Naukowe UAM, 2019

\section{@creative}

Partnerzy
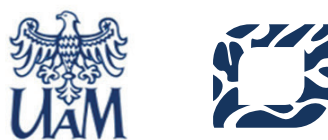

OŚRODEK

PRZETWARZANIA

INFORMACJI

Fundacja

orange

Grafika na okładce: www.freepik.com

Projekt okładki: Helena Oszmiańska

Redaktor: Marzenna Ledzion-Markowska

Redaktor techniczny: Dorota Borowiak

DTP: Monika Tyma

ISBN 978-83-232-3409-8

Cytowanie: Pyżalski, J., Zdrodowska, A., Tomczyk, Ł., Abramczuk, K. (2019). Polskie badanie EU Kids Online 2018. Najważniejsze wyniki i wnioski. Poznań: Wydawnictwo Naukowe UAM

WYDAWNICTWO NAUKOWE UNIWERSYTETU IM. ADAMA MICKIEWICZA W POZNANIU 61-701 POZNAŃ, UL. FREDRY 10

www.press.amu.edu.pl

Sekretariat: tel. 6182946 46, faks 6182946 47, e-mail: wydnauk@amu.edu.pl

Dział Promocji i Sprzedaży: tel. 6182946 40, e-mail: press@amu.edu.pl 


\section{Spis treści}

1. Nota metodologiczna (Jacek Pyżalski, Aldona Zdrodowska) / 7

2. Dzieci i młodzież jako użytkownicy internetu - podstawowe informacje (Jacek Pyżalski) / 17

3. Aktywności młodych ludzi w internecie (Łukasz Tomczyk) / 31

4. Internet w szkole (Jacek Pyżalski) / 41

5. Internet w domu (Aldona Zdrodowska) / 53

6. Środowisko rówieśnicze a internet (Łukasz Tomczyk) / 73

7. Doświadczane ryzyko i poczucie bezpieczeństwa w internecie (Katarzyna Abramczuk) / 79

8. Problematyczne Użytkowanie Internetu (PUI) (Łukasz Tomczyk) / 95

9. Elektroniczna przemoc rówieśnicza (cyberprzemoc) (Jacek Pyżalski) / 101

10. Mowa nienawiści w internecie (Łukasz Tomczyk) / 119

11. Materiały dotyczące seksu i zjawisko sekstingu (Łukasz Tomczyk) / 137

12. Podsumowanie i wnioski (Jacek Pyżalski, Aldona Zdrodowska, Łukasz Tomczyk, Katarzyna Abramczuk) / 155

Bibliografia / 163

Noty o autorach / 175 



\section{Nota metodologiczna}

Jacek Pyżalski (Uniwersytet im. Adama Mickiewicza w Poznaniu)

Aldona Zdrodowska (Ośrodek Przetwarzania Informacji - Państwowy Instytut Badawczy)

Pogłębione badania dotyczące tego, co młodzi ludzie robią w internecie i jak wiąże się to z ich indywidualnym i społecznym rozwojem mają stosunkowo krótką historię. Właściwie moment, od którego możemy mówić o bardziej rozbudowanych programach badawczych i rozpoczęciu zbierania szerzej zakrojonego i pogłębionego materiału z tego obszaru, to przełom XX i XXI wieku (por. Livingstone, 2003). Oczywiście taka aktywność badaczy ma wyraźny związek z rozwojem technologii i masowym upowszechnieniem i dostępnością internetu w wielu krajach, ze szczególnym uwzględnieniem krajów wysoko rozwiniętych. Skoro internet stał się ważnym obszarem funkcjonowania większości młodych ludzi, istotne stało się również empiryczne rozpoznanie ich aktywności online. Warto zwrócić uwagę, że na samym początku najczęściej podejmowane były kwestie zachowań dysfunkcjonalnych czy ryzykownych online oraz ich konsekwencji. Znacznie mniej było projektów badawczych uwzględniających jasną stronę wykorzystania sieci - czyli takich działań młodych ludzi z wykorzystaniem internetu, które przynoszą im indywidualne korzyści, a w wielu sytuacjach są także wartościowe w szerszym społecznym kontekście (Livingstone, Mascheroni, Staksrud, 2018). Takie podejście miało swoje konsekwencje w postaci zniekształconego obrazu funkcjonowania młodych ludzi online. Ten, podszyty paniką moralną, obraz sku- 
piony był głównie na negatywnych działaniach młodych ludzi online i ryzykach, których mogą doświadczyć w sieci. Był on dodatkowo często wzmacniany przez nakierowane na wywołanie skandalu przekazy medialne, bazujące na ekstremalnych przypadkach negatywnego wykorzystania sieci przez młodych ludzi. Co więcej, margines dysfunkcjonalnych zachowań był niejednokrotnie opisywany i interpretowany tak, jakby dotyczył całej populacji. Dodatkowo działania w internecie były w zawężony sposób interpretowane jako wynik wpływu środowiska online, przy jednoczesnym braku doceniania innych czynników. W szczególności środowisko online było uważane za wirtualne i zasadniczo odrębne od środowiska offline, traktowanego jako realne. Takie podejście nie pozostawało bez wpływu na działania praktyczne w obszarze edukacji i wychowania młodych ludzi. Były one wtedy nastawione zasadniczo na profilaktykę zagrożeń, a w znacznie mniejszym stopniu na wspieranie młodych ludzi, tak by potrafili oni wykorzystywać internet w pozytywny i twórczy sposób (Pyżalski, 2016; 2017). Sytuacja ta, w ciągu ostatnich piętnastu lat, uległa zmianie. Wciąż jednak w badaniach problematyki użytkowania internetu przez młodych ludzi możemy zobaczyć wpływ nakreślonego wyżej podejścia, w postaci zachwianej proporcji na rzecz badania zagrożeń oraz koncentracji na podejściu ochronnym w działaniach praktycznych (Pyżalski, 2016; 2017).

Ujęcie badawcze, które zaproponowali w 2006 roku badacze tworzący sieć EU Kids Online, było ambitną próbą integracji teoretycznej problematyki oraz propozycją nowego podejścia badawczego, które pozwoli eksplorować empirycznie zaangażowanie młodych ludzi online w szerszym kontekście oraz dokonywać porównań pomiędzy krajami europejskimi. Model ten integrował uzyskane wcześniej wyniki nielicznych badań europejskich (w 2003 roku było to tylko około 150 publikacji) oraz wyznaczał założenia teoretyczne dla przyszłych projektów badawczych.

Charakteryzowało go kilka kluczowych elementów (Livingstone, Mascheroni, Staksrud, 2018):

1. W modelu w sposób zrównoważony uwzględniono zarówno szanse, jak i ryzyka związane z wykorzystaniem internetu przez młodych ludzi. Przełomem było znaczące uwzględnienie potencjałów i jasnej strony wykorzystania sieci przez młodych ludzi, a także przyjęcie założenia, iż kontakt z ryzykiem (w tym wypadku w sieci) może prowadzić do uodpornienia dziecka poprzez proces uruchamiania strategii zaradczych i budowania rezyliencji (odporności). 
2. Model uwzględniał znaczącą rolę środowiska rodzinnego (w tym mediacyjnej roli rodziców) i szkolnego w moderowaniu zarówno samego zaangażowania dzieci i młodzieży w wykorzystanie internetu, jak i jego jakości i konsekwencji.

3. Model uwzględniał także ważne obszary funkcjonowania offline. Pozwoliło to na analizę powiązania funkcjonowania młodych ludzi online i offline (np. tego, czy ktoś, kto jest ofiarą lub sprawcą cyberprzemocy, pełni także te role offline, np. w szkole). Ważną zmianą, w porównaniu z trendami dominującymi wcześniej, było holistyczne traktowanie funkcjonowania w tych dwóch kontekstach oraz traktowanie internetu bardziej jako przestrzeni funkcjonowania młodych ludzi, a nie czynnika, który wywołuje wpływ na ich zachowanie.

4. Model ten podkreślał nowe role użytkowników internetu (w porównaniu z tzw. mediami tradycyjnymi, gdzie młody człowiek pełnił wyłącznie rolę odbiorcy treści). W przypadku internetu młody człowiek oczywiście dalej może pełnić rolę odbiorcy, ale jest także uczestnikiem relacji rówieśniczych lub relacji z dorosłymi online, oraz aktorem, który inicjuje tworzenie treści lub kontakty z innymi w sieci (Staksrud, Livingstone, 2009).

5. Model zakładał wyodrębnienie części problematyki związanej z wykorzystaniem internetu, która jest uniwersalna i może być podstawą do stworzenia narzędzi pozwalających prowadzić badania w różnych krajach i porównań wskaźników.

Zarysowany wyżej model badawczy stanowił podstawę do przeprowadzenia w latach 2009/2010 szeroko zakrojonych badań kwestionariuszowych (ok. 25.000 respondentów w wieku 9-16 lat oraz ich rodziców/opiekunów z 25 krajów Unii Europejskiej). Efektem badania był rozbudowany, szeroko upowszechniony raport oraz szereg innych publikacji pogłębiających poszczególne badane aspekty (Livingstone, Haddon, Görzig, Ólafsson, 2011). W projekcie tym brała udział także Polska, gdzie zrealizowano badania na próbie 1034 dzieci i młodzieży w wieku 9-16 lat i ich rodziców (Kirwil, 2011).

W następnych latach zrealizowano jeszcze węziej zakrojone badania skoncentrowane na wykorzystaniu przez młodych ludzi technologii mobilnych. W tym projekcie jednak badania w Polsce nie były prowadzone (Mascheroni, Ólafsson, 2014). 
Sieć EU Kids Online zdecydowała się na przygotowanie w latach 2017-2018 drugiej fali badań. Z jednej strony postanowiono pozostawić zasadnicze elementy modelu badawczego w celu umożliwienia porównań z wynikami z roku 2010, z drugiej zaś strony zmiany technologiczne oraz nowe zjawiska społeczne związane z wykorzystaniem internetu przez młodych ludzi wywołały konieczność zmian. Polegały one na uzupełnieniu czy przeformułowaniu niektórych pytań (np. tych dotyczących urządzeń, za pomocą których respondenci łączą się z internetem). Zmiany te dotyczyły dodania bloków pytań odnoszących się do zjawisk, które wcześniej nie tylko w badaniach EU Kids Online były podejmowane w ograniczonym zakresie. Moduły te obejmowały np. problem tzw. mowy nienawiści w internecie, poszukiwania informacji dotyczących zdrowia czy działań młodych ludzi w sytuacji, kiedy są świadkami cyberprzemocy. Włączenie tych modułów wiązało się z niezależną decyzją zespołów naukowców z każdego kraju. W Polsce uznaliśmy, że należy włączyć moduły dotyczące mowy nienawiści, jako zidentyfikowanego w innych badaniach problemu społecznego w naszym kraju (zarówno w kontekście działania online, jak i szerszym). Warto jednak zauważyć, że z reguły badania były prowadzone na próbach osób dorosłych i starszej młodzieży (por. Bilewicz i in., 2014). Do tego zdecydowano się włączyć moduł dotyczący zachowań i emocji świadków cyberprzemocy. To bardzo istotny obszar badawczy ze względu na to, że aktywne działanie świadków może stanowić bardzo ważny czynnik wpływający na zatrzymanie aktów przemocy rówieśniczej (zarówno tej tradycyjnej, jak i w internecie (Macháčková i in., 2013; Pyżalski, 2012).

Generalnie w badaniu zastosowano model badawczy zgodny z przedstawionym wcześniej założeniami pierwszej fali badań EU Kids Online (rys. 1). Warto tu zwrócić uwage na fakt poszerzenia wiekowo grupy do 17. roku życia (w 2009/2010 było to 16 lat). Model uwzględnia więc zarówno szanse (potencjały), jak i zagrożenia (ryzyka) wynikające z używania internetu oraz dwa kluczowe środowiska - rodzinne i szkolne, które są źródłem czynników ryzyka wpływających na zaangażowanie w zachowania ryzykowne online, oraz czynników chroniących przed takim zaangażowaniem, a jednocześnie wspomagających konstruktywne wykorzystanie sieci (prospołeczne i prorozwojowe). Dodatkowo model uwzględniał wybrane aspekty funkcjonowania offline oraz rozbudowaną listę czynników społeczno-demograficznych.

Obecna fala badań realizowana jest w krajach Unii Europejskiej oraz krajach spoza Unii, między innymi w Rosji. 
W Polsce badania zrealizował zespół kierowany przez prof. UAM dra hab. Jacka Pyżalskiego z Wydziału Studiów Edukacyjnych Uniwersytetu im. Adama Mickiewicza w Poznaniu. W skład zespołu wchodzą mgr Aldona Zdrodowska i dr Katarzyna Abramczuk z Ośrodka Przetwarzania Informacji - Państwowego Instytutu Badawczego oraz dr inż. Łukasz Tomczyk z Uniwersytetu Pedagogicznego im. Komisji Edukacji Narodowej w Krakowie.

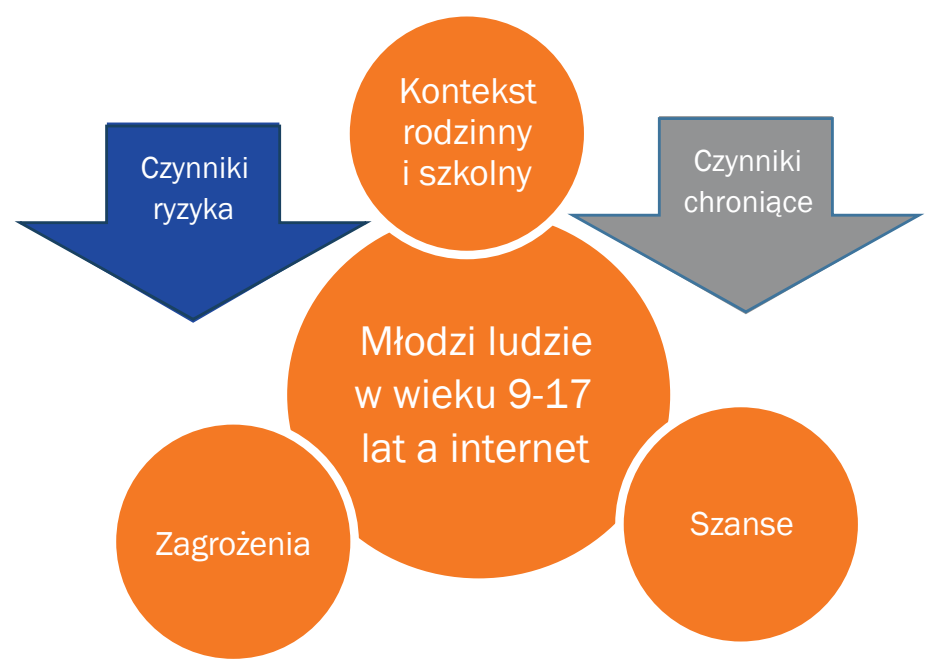

Rys. 1.1. Model badawczy zastosowany w badaniu EU Kids Online 2018

\section{Dobór próby i przebieg badania}

Obecna edycja badania EU Kids Online została zrealizowana w Polsce w terminie od maja do czerwca 2018 roku w 90 szkołach. Zastosowany schemat doboru został skonstruowany w taki sposób, aby otrzymać reprezentatywną próbę uczniów szkół podstawowych, gimnazjalnych i ponadgimnazjalnych, odpowiadającą strukturze populacji uczniów w wieku 9-17 lat w Polsce. W tym celu zastosowany został schemat losowania wielostopniowego. W pierwszym etapie doboru wylosowane zostały szkoły. Dobór odbywał się przy pomocy proporcjonalnego schematu doboru w warstwach (wg typów szkół i klas). Operatem losowania był aktualny wykaz szkół z Systemu Informacji Oświatowej, zawierający dane o liczbie uczniów w określonej placówce edukacyjnej. Na podstawie tych informacji została oszacowana liczba uczniów dla badanych typów klas. Losowanie 
szkół zostało zrealizowane przy wykorzystaniu schematu doboru systematycznego w warstwach z prawdopodobieństwem proporcjonalnym do oszacowanej wielkości populacji (liczby uczniów) w danej szkole. Oprócz próby podstawowej wylosowana została próba rezerwowa wg tego samego schematu doboru. W kolejnym kroku, w każdej z placówek wylosowano jedną klasę. Rozkład szkół według poziomu edukacji w poszczególnych województwach przedstawia poniższa tabela.

Tabela 1.1. Szkoły uwzględnione w badaniu wg województwa oraz poziomu edukacji

\begin{tabular}{|c|c|c|c|c|}
\hline Województwo & $\begin{array}{c}\text { Szkoła } \\
\text { podstawowa }\end{array}$ & Gimnazjum & $\begin{array}{c}\text { Szkoła } \\
\text { ponad- } \\
\text { gimnazjalna }\end{array}$ & Łącznie \\
\hline dolnośląskie & 4 & 0 & 0 & 4 \\
\hline kujawsko-pomorskie & 5 & 0 & 1 & 6 \\
\hline lubelskie & 2 & 0 & 0 & 2 \\
\hline lubuskie & 3 & 0 & 2 & 5 \\
\hline łódzkie & 5 & 0 & 1 & 6 \\
\hline małopolskie & 7 & 0 & 1 & 8 \\
\hline mazowieckie & 12 & 0 & 4 & 16 \\
\hline opolskie & 2 & 1 & 0 & 3 \\
\hline podkarpackie & 5 & 2 & 2 & 9 \\
\hline podlaskie & 2 & 0 & 0 & 2 \\
\hline pomorskie & 4 & 1 & 0 & 5 \\
\hline śląskie & 3 & 0 & 3 & 6 \\
\hline świętokrzyskie & 1 & 0 & 0 & 1 \\
\hline warmińsko-mazurskie & 4 & 1 & 2 & 7 \\
\hline wielkopolskie & 7 & 0 & 0 & 7 \\
\hline zachodniopomorskie & 3 & 0 & 0 & 3 \\
\hline Łącznie & 69 & 5 & 16 & 90 \\
\hline
\end{tabular}

Liczba uczestniczących w badaniu szkół z poszczególnych województw w podziale na poziom szkoły

W każdej z wylosowanych klas do udziału w badaniu zaproszono zarówno dzieci i młodzież (obecne w dniu badania), jak i po jednym z ich rodziców/ opiekunów (którzy wypełniali w domu przyniesiony przez dziecko ze szkoły kwe- 
stionariusz ${ }^{1}$ ). Realizację badania prowadzili przeszkoleni ankieterzy. Za zgodą dyrektorów szkół, po ich uprzednim pisemnym powiadomieniu, wchodzili oni do zespołów klasowych na jedną godzinę lekcyjną i towarzyszyli respondentom w wypełnianiu ankiety online (na sprzęcie szkolnym). Ankieter był obecny w klasie przez cały czas badania, tj. do momentu wypełnienia ankiety przez wszystkich uczestników. Zgodnie z przyjętymi założeniami metodologicznymi, po zakończeniu każdego badania w wylosowanej szkole, ankieter wypełniał Arkusz Realizacji Badania, w którym odnotowywał wszystkie istotne dla przebiegu badania informacje: datę i godzinę badania, adres szkoły, badane klasy, liczbę uczniów uczestniczących w badaniu oraz własne uwagi z przebiegu badania. Każdorazowo ww. arkusz był także potwierdzony przez dyrektora lub wicedyrektora szkoły imienną pieczątką oraz pieczęcią szkoły. Dodatkowo, aby zapewnić najwyższy poziom rzetelności badań, realizator wykonał telefony do 15 szkół, w których odbywały się badania, potwierdzając i weryfikując informacje zawarte w Arkuszach Realizacji Badania. Wszystkie rozmowy kontrolujące przebieg procedury badawczej potwierdziły prawdziwość i rzetelność danych zawartych w dokumentacji badań przekazanej przez poszczególnych ankieterów.

\section{Kwestionariusz}

Na potrzeby obecnej fali badania EU Kids Online opracowano nowe, zaktualizowane i rozszerzone kwestionariusze dla dzieci i opiekunów przygotowane przez naukowców zarządzających siecią EU Kids Online². Pytania z wersji oryginalnej (angielskiej) były następnie tłumaczone na języki europejskie przez krajowe zespoły badawcze i/lub agencje realizujące badania terenowe.

Pełen kwestionariusz dla dzieci i nastolatków obejmuje pięć kategorii pytań - obowiązkowe, rozszerzone, opcjonalne, opcjonalne dla dzieci młodszych oraz tzw. nowe moduły. Zadanie uczestnikom wszystkich opracowanych w ramach projektu pytań jest w praktyce niemożliwe ze względu na wymagania czasowe i zmęczenie osób badanych, szczególnie w przypadku młodszych dzieci. Dlatego każdy kraj mógł skonstruować własny kwestionariusz zawie-

\footnotetext{
1 Jak wskazano wcześniej, wyniki badania rodziców zostaną przedstawione w osobnej publikacji.

2 Informacje o projekcie EU Kids Online, metodologii i składzie Zespołu Zarządzającego oraz Zespołach Badawczych w poszczególnych krajach można znaleźć na stronie: http://www.lse. ac.uk/media-and-communications/research/research-projects/eu-kids-online.
} 
rający pytania obowiązkowe oraz wybrany zestaw pytań z kategorii rozszerzonych, opcjonalnych i/lub nowych modułów. Pytania obowiązkowe (core questions) to blok składający się z najważniejszych pytań z roku 2010 (zaktualizowanych tak, aby uwspółcześnić treść tam, gdzie było to konieczne, zachowując możliwość porównań między latami 2010 i 2018) oraz pytania obejmujące nowe zjawiska związane z korzystaniem z technologii sieciowych. Zgodnie z założeniami projektu pytania z trzonu należało zadać we wszystkich krajach biorących udział w drugiej fali badania. Bloki pytań rozszerzonych (extended core questions) i opcjonalnych (optional questions) zawierają dodatkowe pytania zarówno z roku 2010, jak i nowe, przy czym zalecane jest wykorzystanie w pierwszej kolejności pytań z części rozszerzonej. Część pytań z trzech wymienionych wyżej kategorii została oznakowana dodatkowo jako pytania opcjonalne, niezalecane dla dzieci młodszych (9-10 lat) ze względu na poziom trudności i/lub kwestie etyczne. Na ostatnią kategorię - tzw. nowe moduły składają się zestawy pytań dotyczące kilku kategorii zjawisk nieporuszanych w badaniach w roku 2010, m.in. jak wspomniano już wcześniej, wybrane do polskiego kwestionariusza pytania o sytuację bycia świadkiem cyberprzemocy (cyber bystanders module) czy doświadczanie mowy nienawiści i dyskryminacji w sieci (cyberhate/discrimination module). W większości przypadków, w poszczególnych tabelach prezentujących wyniki badań, zadane pytania przedstawiamy w oryginalnym brzmieniu.

Kwestionariusz dla rodziców również składa się z bloków obowiązkowego i opcjonalnego, przy czym polska wersja zawiera pytania dodatkowe. Niniejsza publikacja przedstawia jedynie wyniki badania młodych ludzi.

\section{Próba badawcza}

Ankiety online wypełniło łącznie 1433 uczniów. Do dalszych analiz zakwalifikowano wyłącznie odpowiedzi uczniów, którzy w miesiącu badania mieli nie mniej niż dziewięć lat (ukończone) i nie ukończyli 17 lat. Z analiz wyłączono również ankiety z brakami w zakresie danych dotyczących wieku i płci. Ostatecznie do analiz na poziomie krajowym przyjęto próbę $N=1249$ uczniów w wieku od 9 do 17 lat $(M=12,8 ; S D=2,5)$, z których 47,3\% stanowili chłopcy. Szczegółowy rozkład, wg płci i dwóch rodzajów kategorii wiekowych przyjętych w modelu badawczym projektu EU Kids Online, zawiera tabela 1.2. 
Tabela 1.2. Charakterystyka badanej próby ze względu na płeć i grupy wiekowe

\begin{tabular}{|c|c|c|c|c|c|c|}
\hline \multicolumn{1}{|c|}{ Wiek } & \multicolumn{2}{|c|}{ Chłopcy } & \multicolumn{2}{c|}{ Dziewczynki } & \multicolumn{2}{|c|}{ Łącznie } \\
\hline 9 - 10 lat & Liczebność & $\%$ z N & Liczebność & $\%$ z N & Liczebność & $\%$ z N \\
\hline 11 - 17 lat & 129 & 10,3 & 135 & 10,8 & 264 & 21,1 \\
\hline & 462 & 37,0 & 523 & 41,9 & 985 & 78,9 \\
\hline 9 - 10 lat & 129 & 10,3 & 135 & 10,8 & 264 & 21,1 \\
\hline 13 - 12 lat & 166 & 13,3 & 177 & 14,2 & 343 & 27,5 \\
\hline 15 - 17 lat & 146 & 11,7 & 177 & 14,2 & 323 & 25,9 \\
\hline
\end{tabular}

$\mathrm{N}=1249$

\section{Sposób opracowania wyników}

Analizy opisowe przedstawione w kolejnych rozdziałach niniejszego raportu sa oparte o wyniki surowe, zebrane w badaniu na próbie 1249 uczniów w wieku od 9 do 17 lat, uczęszczających w drugim semestrze roku szkolnego 2017/2018 do publicznych szkół podstawowych, gimnazjalnych i ponadpodstawowych w Polsce. Ze względu na braki danych - systematyczne oraz niesystematyczne $^{3}$ - w odpowiedziach na poszczególne pytania kwestionariusza, tabele z wynikami procentowymi każdorazowo zawierają informację o liczebności podstawy, do której się odwołują. Analizy w raporcie zawierają w niektórych przypadkach, oprócz odpowiedzi diagnostycznych dla poszczególnych pytań, także kategorie „Nie wiem / Wolę nie odpowiadać”, ze względu na ich wartość informacyjną. W prezentacji wyników, zgodnie z wytycznymi EU Kids Online

3 Jak opisano wcześniej, we fragmencie dotyczącym kwestionariusza badania EU Kids Online, część pytań badawczych została zadana - ze względów etycznych i/lub technicznych - wyłącznie starszym uczniom ( $w$ wieku 11-17 lat). Ponadto schemat badania został pomyślany w taki sposób, aby część pytań pogłębionych (np. dotyczących reakcji emocjonalnej w odpowiedzi na zagrożenia doświadczane w sieci) została zadana tylko tym dzieciom, których faktycznie dotyczą (np. tym, które w pytaniu przesiewowym zadeklarowały, że doświadczyły danego rodzaju zagrożenia). Błędy niesystematyczne wynikały przede wszystkim z pozostawienia przez badanych pojedynczych pytań bez odpowiedzi. Więcej szczegółowych informacji metodologicznych zawiera raport techniczny z badania EU Kids Online 2018 (w przygotowaniu). 
oraz Global Kids Online, przyjęto dwa rodzaje podziału na kategorie wiekowe: a) podział na dzieci młodsze (9-10 lat) i starsze (11-17 lat) oraz b) cztery grupy wiekowe: 9-10, 11-12, 13-14 i 15-17 lat.

\section{Kwestie etyczne}

Międzynarodowe konsorcjum badawcze EU Kids Online podjęło decyzję, że niektóre pytania związane z kwestiami drażliwymi obyczajowo (np. sekstingiem) nie muszą być zadawane młodszym respondentom. Polski zespół badawczy zdecydował się wyłączyć te pytania z narzędzia dla grupy wiekowej 9-10 lat.

Założenia badawcze, procedura oraz narzędzia kwestionariuszowe uzyskały pozytywną decyzję Komisji Etycznej Wydziału Studiów Edukacyjnych UAM w Poznaniu, która zarekomendowała dodatkowe wytyczne ponad te, które zostały ustalone na poziomie konsorcjum, dotyczące m.in. informacji dla dyrektorów placówek, gdzie prowadzone były badania. Wytyczne te zostały uwzględnione w zastosowanej procedurze badawczej. Dyrektorzy szkół decydowali o wstępnej zgodzie wylosowanej placówki na udział w badaniu.

Badanie opierało się na zasadach zgody rodziców, którzy mogli wcześniej zapoznać się z narzędziem badawczym, oraz zgody dziecka, co do udziału w badaniach (możliwość nieprzystąpienia do badania, rezygnacji z odpowiedzi na niektóre pytania oraz wycofania się na każdym etapie procesu badawczego). Informacje na ten temat były umieszczone zarówno w pisemnych, jak i ustnych komunikatach kierowanych do respondentów i ich rodziców.

Kody do porównań odpowiedzi dzieci i ich rodziców ${ }^{4}$ skonstruowano w sposób uniemożliwiający badaczom identyfikację konkretnych respondentów, tak aby zapewnić pełną anonimowość uzyskanych danych.

${ }^{4}$ Wyniki badań rodziców i zestawienie odpowiedzi rodziców i dzieci zostaną przedstawione w kolejnych publikacjach. 


\section{Dzieci i młodzież}

\section{jako użytkownicy internetu - podstawowe informacje}

Jacek Pyżalski (Uniwersytet im. Adama Mickiewicza w Poznaniu)

Większość badań dotyczących użytkowania internetu przez młodych ludzi obejmuje w jakimś stopniu problematykę urządzeń dostępowych oraz czasu korzystania. Podobnie jest w przypadku badania EU Kids Online.

Realizowane wcześniej w naszym kraju badania ilościowe także dotyczyły tych kwestii. Z pierwszej edycji badań EU Kids Online (Kirwil, 2010), opublikowanych prawie dekadę temu, wynika, że młodzi ludzie (w wieku 9-16 lat) łączyli się z internetem głównie przez dzielony z innymi (57\%) lub własny komputer stacjonarny. Jedynie 13\% używało laptopa własnego i 13\% laptopa wspólnego z innymi użytkownikami. Telefon komórkowy do łączenia z internetem używany był przez 37\% młodych ludzi. Wyraźnie więc widać dominację stacjonarnego korzystania z internetu, z częściowym jedynie uzupełnianiem takiego dostępu poprzez stosowanie urządzeń mobilnych. W tych samych badaniach wykazano, że 96\% polskich dzieci logowało się do sieci codziennie, a 24\% 1-2 razy w tygodniu (Kirwil, 2010).

Postęp technologiczny oraz spadek cen zarówno sprzętu, jak i opłat za połączenie z internetem znacząco zmienił ten obraz. Dekadę później wygląda on zupełnie inaczej. 
Nowsze dane wskazują na zdecydowanie rosnącą powszechność wykorzystania internetu przez młodych ludzi. W badaniu Nastolatki 3.0 (Tanaś i in., 2017) stwierdzono, iż jedynie 0,7\% respondentów nie korzysta nigdy z internetu w domu, a aż $80 \%$ robi to wiele razy dziennie bądź niemal przez cały czas. Ten ostatni wskaźnik najczęstszego wykorzystania internetu przyjmuje niższe wartości w przypadku łączenia się z internetem w szkole (ok. 39\%) czy u znajomych (ok. 42\%). W badaniu tym stwierdzono także dodatnią korelację wieku i częstotliwości korzystania z internetu.

Omawiane badanie wyraźnie wskazuje na szczególne znaczenie internetu mobilnego w funkcjonowaniu nastolatków, który jeszcze dekadę temu był dużo słabiej rozpowszechniony w całej populacji użytkowników (por. Batorski, 2015). Autorzy badania Nastolatki 3.0, porównując wyniki wcześniejszych analiz empirycznych (Lange, Osiecki, 2014), mocno podkreślają tendencję wzrostową w zakresie mobilnego łączenia się z siecią wśród młodych ludzi. Kluczowymi narzędziami do łączenia się z internetem (gdzie wskaźnikiem jest dobowy czas wykorzystania) okazały się telefon komórkowy i smartfon oraz laptop. Rzadko wykorzystywano komputer stacjonarny, a jeszcze rzadziej tablet i konsolę do gier. Badania te wykazały także, iż stacjonarne formy łączenia z internetem (poprzez laptop lub komputer stacjonarny) były częściej wykorzystywane przez chłopców.

W obecnej edycji badania EU Kids Online pytaliśmy o częstotliwość korzystania z poszczególnych urządzeń, a także czas przebywania online w dni robocze oraz weekendowe.

Problematyka wykorzystania internetu została poszerzona o kwestię posiadania konta w profilu społecznościowym jako specyficznej i istotnej z punktu widzenia potencjalnych szans oraz zagrożeń aktywności online (Valkenburg, Peter, Schouten, 2006). Jak pokazują badania, funkcjonowanie w portalach społecznościowych ma dla młodych ludzi podobne cele, jak inne rodzaje tradycyjnej komunikacji, tj. „utrzymywanie kontaktów z przyjaciółmi, planowanie, lepsze poznawanie innych ludzi oraz autoprezentację" (Spies Shapiro, Margolis, 2014, s. 1).

Do rozdziału wstępnego włączyliśmy także analizy wyników dotyczących samooceny badanych w zakresie wybranych umiejętności internetowych oraz ich zgeneralizowanych postaw związanych z własnym funkcjonowaniem online. 


\section{Jak młodzi ludzie łączą się z internetem?}

Badani określali, jak często korzystają ze wskazanych urządzeń dostępowych, by łączyć się z internetem.

Wykres 2.1. Jak często jesteś online albo korzystasz z internetu za pomocą wymienionych urządzeń?

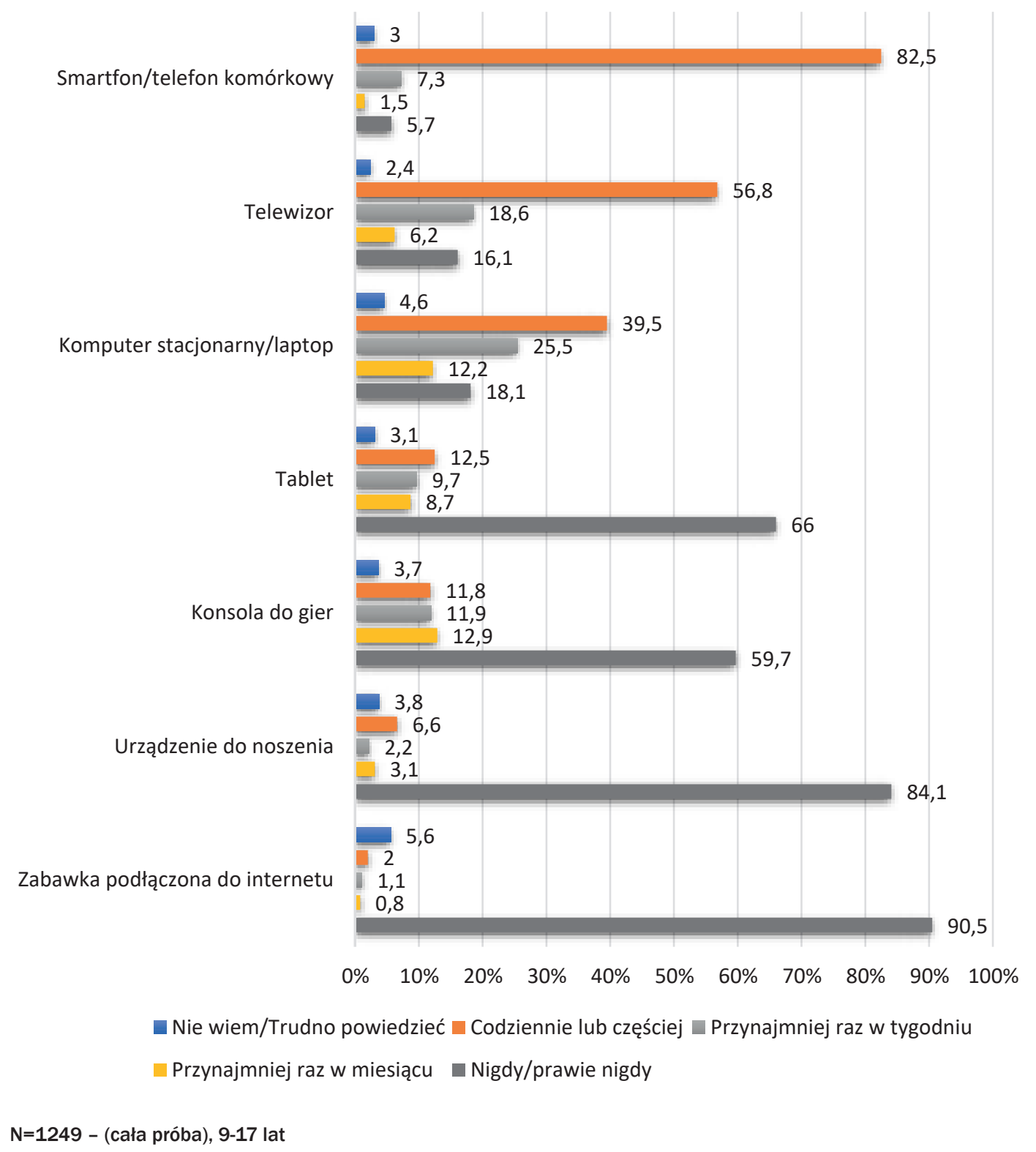


Zdecydowanie na pierwszym miejscu wśród urządzeń służących do łączenia się z internetem znajduje się telefon komórkowy/smartfon. Korzystało z niego codziennie lub częściej 82,5\% badanych. Odsetek badanych korzystających do łączenia się z internetem za pomocą telewizora wynosił prawie 57\%, a za pomocą laptopa i komputera stacjonarnego prawie 40\%. Dużo rzadziej wykorzystywane były takie urządzenia, jak tablet (12,5\%) czy konsola do gier (11,8\%). Jedynie nieliczni wykorzystywali urządzenia do noszenia, np. zegarki $(6,6 \%)$ i zabawki podłączone do internetu (2\%).

Należy zaznaczyć, że chłopcy częściej niż dziewczęta korzystali ze stacjonarnych możliwości połączenia się z internetem.

\section{Ważny fakt}

Chłopcy częściej niż dziewczęta korzystali z internetu stacjonarnie.

$51,5 \%$ chłopców codziennie lub prawie codziennie łączyło się z internetem za pomocą komputera stacjonarnego lub laptopa. Robiło to jedynie $28,7 \%$ dziewcząt $(p<0,001)$

Natomiast młodsze dzieci, by połączyć się z internetem, rzadziej niż młodzież korzystały ze smartfonów, komputerów stacjonarnych/laptopów.

\section{Ważny fakt}

Młodsi nieco rzadziej używają smartfonów, komputerów stacjonarnych/laptopów, żeby być online.

13,6\% 9-10-latków nigdy lub prawie nigdy nie łączyło się z internetem za pomocą smartfona. Wśród młodzieży w wieku 11-17 lat jest tylko 3,5\% takich osób (chi²=100,6 p<0,0001). Ponad 1/3 młodych ludzi w wieku 9-10 lat nie łączyło się z internetem za pomocą komputera stacjonarnego/laptopa. Natomiast w grupie 11-17-latków takich osób jest mniej niż 15\% ( $p<0,0001)$. 


\section{Jak wielu młodych ludzi posiada profile w portalach społecznościowych?}

Posiadanie profilu w portalu społecznościowym jest bardzo rozpowszechnionym sposobem korzystania z internetu, który może nieść ze sobą szereg korzyści (np. pomagać budować relacje społeczne, wymieniać informacje), jak i sporo zagrożeń (np. narażać na cyberprzemoc, naruszać prywatność) (Spies Shapiro, Margolin, 2014). Poniżej przedstawiono podstawowe informacje na temat posiadania konta w portalu społecznościowym (lub innym podobnym serwisie), które zebrano w naszych badaniach. Warto zauważyć, że w badaniach tych, w jednej kategorii zaangażowania online, połączono nieco różniące się aktywności - badani potwierdzając posiadanie profilu, mogą odnosić je do głównych popularnych serwisów o tym charakterze - np. Facebook, Instagram, Snapchat, YouTube, ale też do serwisów o węższym gronie użytkowników, np. związanych z jakąś grą komputerową lub w ogóle niewielkich, niszowych portali. Należy o tym pamiętać, interpretując wyniki, gdyż typowe zaangażowanie użytkownika jest różne w zależności od tego, gdzie posiada konto. I tak, typowy profil w portalu społecznościowym służy publikowaniu treści kierowanych do różnych publiczności online, podczas gdy konto gracza będzie często instrumentalnym narzędziem służącym do korzystania z określonej gry, gdzie publikowane informacje będą miały bardziej ograniczony charakter.

Tabela 2.1. Czy masz swój własny profil w serwisie społecznościowym, w mediach społecznościowych albo na stronie $z$ grami internetowymi, w które grasz?

\begin{tabular}{|c|c|c|c|c|c|c|c|c|c|}
\hline Płeć & Wszyscy & Chłopcy & Dziewczęta & Wszyscy & Chłopcy & Dziewczęta & Wszyscy & Chłopcy & Dziewczęta \\
\hline Wiek & $9-17$ lat & 9-17 lat & $9-17$ lat & $9-10$ lat & $9-10$ & $9-10$ & $11-17$ lat & $11-17$ lat & $11-17$ lat \\
\hline$\%$ & 72,6 & 73,1 & 72,2 & 47,7 & 53,5 & 42,2 & 79,3 & 78,6 & 79,9 \\
\hline
\end{tabular}

W całej próbie profil posiadało $72,6 \%$ i brak było w tym zakresie istotnych różnic pomiędzy chłopcami i dziewczętami. Wyraźnie rzadziej posiadały profil dzieci młodsze (mniej niż połowa) w porównaniu z młodzieżą (prawie 80\%). Istotną różnicę statystyczną $(p<0,001)$ zaobserwowano w grupie młodszej - chłopcy częściej posiadali profil w porównaniu z dziewczętami, a różnica wynosiła w tym przypadku prawie 10 punktów procentowych. 


\section{Ile czasu młodzi ludzie spędzają w sieci?}

Czas spędzany online jest jednym z najczęściej badanych i dyskutowanych wskaźników wykorzystania internetu przez młodych ludzi. Z wielu względów, do których wrócimy w dyskusji, koncentrowanie się głównie na tym aspekcie bardzo zawęża sposób myślenia o tym, jak młodzi ludzie funkcjonują online.

Wykres 2.2. Jak dużo czasu spędzasz w internecie (dzień weekendowy i dzień roboczy)?

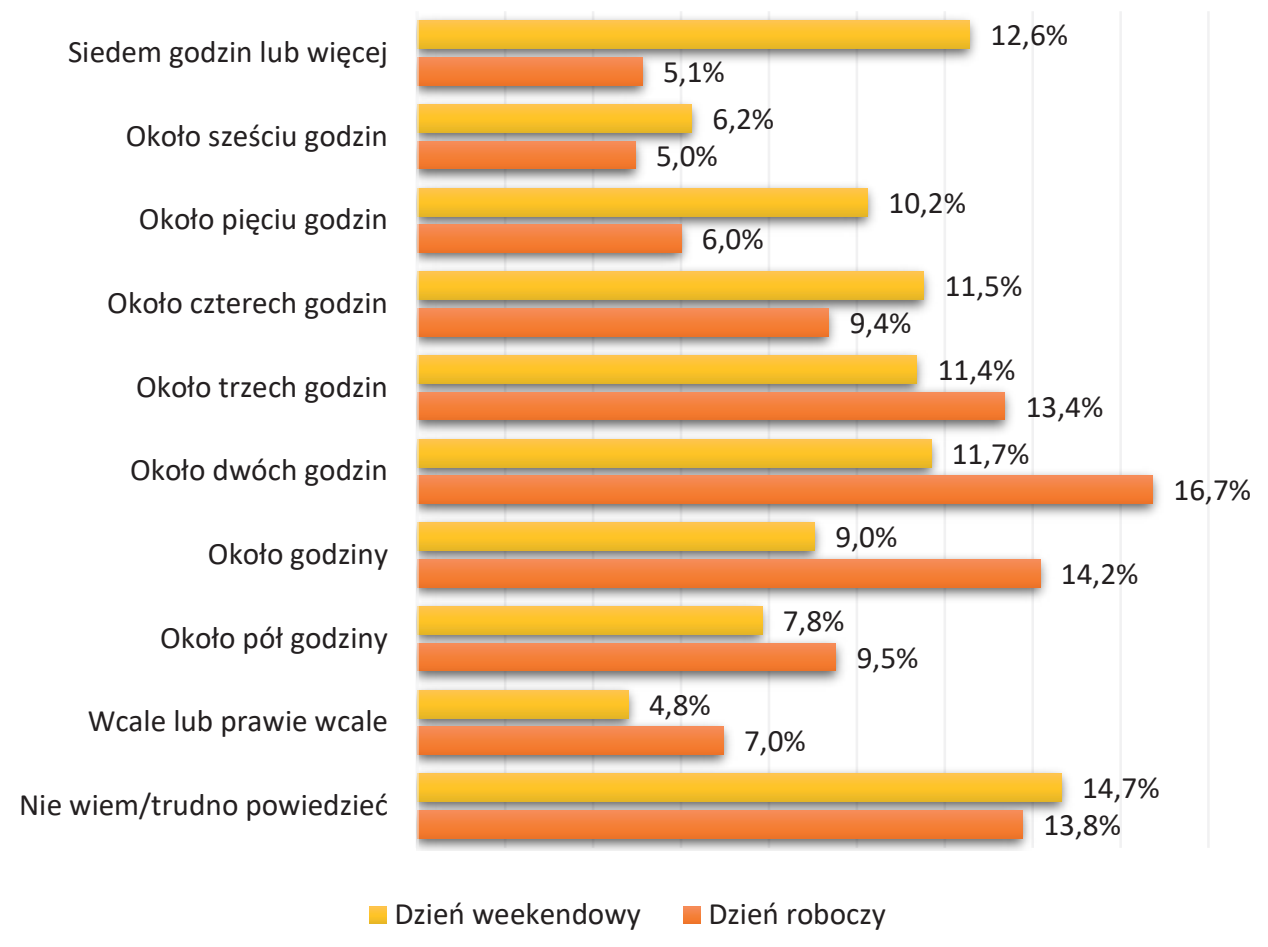

Generalnie prawie połowa młodych ludzi z internetu korzysta do 2 godzin w dni robocze oraz do 3 godzin w dni weekendowe. Osób, które nie korzystają wcale lub prawie wcale, jest odpowiednio $7 \%$ w dni robocze i prawie $5 \%$ w weekendowe. Blisko 19\% młodych ludzi w dzień weekendowy korzysta z internetu 6 godzin i więcej. Tylko co dziesiąty tak długo korzysta w dzień roboczy.

Warto przyjrzeć się rozkładom czasu korzystania z internetu w dni robocze i weekendowe w grupach młodszych (9-10 lat) i starszych (11-17 lat) uczniów. 
W obydwu przypadkach mamy do czynienia z różnicami istotnymi statystycznie. Po pierwsze, warto zauważyć generalną tendencję, że młodzież korzystała z internetu dłużej niż dzieci zarówno w dni robocze, jak i weekendowe. Różnice są tutaj znaczące. Jeśli zsumujemy odsetki, to do godziny korzystało w dni robocze prawie 56\% młodszych respondentów oraz jedynie 24\% respondentów starszych. Podobna tendencja widoczna była w dni weekendowe (odpowiednio ok. $45 \%$ i ok. $26 \%)$.

Tabela 2.2. Jak dużo czasu spędzasz w internecie (dzień roboczy)?

\begin{tabular}{|c|c|c|c|c|c|c|c|c|c|c|}
\hline Wiek & $\begin{array}{c}\text { Nie chcę } \\
\text { powiedzieć/ } \\
\text { trudno } \\
\text { powiedzieć } \\
\%\end{array}$ & $\begin{array}{l}\text { Wcale } \\
\text { lub } \\
\text { prawie } \\
\text { wcale } \\
\%\end{array}$ & $\begin{array}{c}\text { Około } \\
\text { pół } \\
\text { godziny } \\
\text { \% }\end{array}$ & $\begin{array}{c}\text { Około } \\
\text { jednej } \\
\text { godziny } \\
\%\end{array}$ & $\begin{array}{l}\text { Około } \\
\text { dwóch } \\
\text { godzin } \\
\%\end{array}$ & $\begin{array}{l}\text { Około } \\
\text { trzech } \\
\text { godzin } \\
\%\end{array}$ & $\begin{array}{c}\text { Około } \\
\text { czterech } \\
\text { godzin } \\
\%\end{array}$ & $\begin{array}{c}\text { Około } \\
\text { pięciu } \\
\text { godzin } \\
\%\end{array}$ & $\begin{array}{c}\text { Około } \\
\text { sześciu } \\
\text { godzin } \\
\%\end{array}$ & $\begin{array}{c}\text { Siedem } \\
\text { godzin } \\
\text { i więcej } \\
\%\end{array}$ \\
\hline $\begin{array}{l}9-10 \\
\text { lat }\end{array}$ & 10,6 & 13,3 & 21,2 & 21,2 & 15,5 & 8,0 & 4,9 & 2,7 & 2,7 & 0,0 \\
\hline $\begin{array}{l}11-17 \\
\text { lat }\end{array}$ & 14,6 & 5,3 & 6,4 & 12,3 & 17,1 & 14,8 & 10,6 & 6,9 & 5,6 & 6,5 \\
\hline
\end{tabular}

$\mathrm{N}=1249-\mathrm{chi}^{2}=127,6 \mathrm{p}<, 0001$

Druga widoczna tendencja to dłuższy czas korzystania z internetu w dni weekendowe w obydwu grupach wiekowych. Warto tu zwrócić uwage szczególnie na młodzież, gdyż częściej niż co piąty przedstawiciel tej grupy korzystał z internetu w dzień weekendowy 6 godzin i więcej. Jednocześnie nawet wśród młodszych dzieci ta grupa to ponad $6 \%$.

Tabela 2.3. Jak dużo czasu spędzasz w internecie (dzień weekendowy)?

\begin{tabular}{|c|c|c|c|c|c|c|c|c|c|c|}
\hline Wiek & $\begin{array}{c}\text { Nie chcę } \\
\text { powiedzieć/ } \\
\text { trudno } \\
\text { powiedzieć } \\
\%\end{array}$ & $\begin{array}{c}\text { Wcale } \\
\text { lub } \\
\text { prawie } \\
\text { wcale } \\
\%\end{array}$ & $\begin{array}{c}\text { Około } \\
\text { pół } \\
\text { godziny } \\
\text { \% }\end{array}$ & $\begin{array}{c}\text { Około } \\
\text { godziny } \\
\%\end{array}$ & $\begin{array}{l}\text { Około } \\
\text { dwóch } \\
\text { godzin } \\
\%\end{array}$ & $\begin{array}{l}\text { Około } \\
\text { trzech } \\
\text { godzin } \\
\%\end{array}$ & $\begin{array}{c}\text { Około } \\
\text { czterech } \\
\text { godzin } \\
\%\end{array}$ & $\begin{array}{c}\text { Około } \\
\text { pięciu } \\
\text { godzin } \\
\%\end{array}$ & $\begin{array}{l}\text { Około } \\
\text { sześciu } \\
\text { godzin } \\
\%\end{array}$ & $\begin{array}{c}\text { Siedem } \\
\text { godzin } \\
\text { i więcej } \\
\%\end{array}$ \\
\hline 9-10 lat & 9,5 & 10,6 & 15,9 & 18,2 & 17,4 & 8,3 & 9,8 & 4,2 & 2,7 & 3,4 \\
\hline $\begin{array}{l}11-17 \\
\text { lat }\end{array}$ & 16,0 & 3,2 & 5,7 & 6,6 & 10,2 & 12,2 & 12,0 & 11,9 & 7,2 & 15,0 \\
\hline
\end{tabular}

$\mathrm{N}=1249-\mathrm{chi}^{2}=140,1 \mathrm{p}<, 0001$ 
Wysokie były odsetki młodych ludzi, którzy nie chcą powiedzieć lub trudno im określić, jak długo korzystają z internetu. Zwykle takich kategorii się nie omawia - w tym przypadku warto je jednak przedyskutować i zostanie to zrobione w dyskusji na końcu tego rozdziału.

\section{Jakie umiejętności związane z internetem deklarują młodzi ludzie?}

Respondenci dokonali samooceny kompetencji w zakresie umiejętności internetowych wymienionych w kwestionariuszu. Tabela 2.4 przedstawia odsetki tych, którzy w każdym przypadku ocenili własne umiejętności najwyżej (na 5 w pięciostopniowej skali). Oczywiście należy pamiętać, że w żadnym wypadku wyników w tym zakresie nie można interpretować jako wskaźników rzeczywistych umiejętności, którymi mogą wykazać się badani, a jedynie ich przekonania dotyczące tego co potrafią.

Tabela 2.4. Jak młodzi ludzie oceniają własne umiejętności internetowe (odsetki oceniających najwyżej)?

\begin{tabular}{|c|c|c|c|}
\hline Deklarowane umiejętności & $\begin{array}{c}\text { Cała próba } \\
\%\end{array}$ & $\begin{array}{c}\text { Chłopcy } \\
\%\end{array}$ & $\begin{array}{c}\text { Dziewczęta } \\
\%\end{array}$ \\
\hline $\begin{array}{l}\text { Wiem, jak instalować aplikacje na } \\
\text { urządzeniu mobilnym (np. telefonie lub } \\
\text { tablecie) }\end{array}$ & 74,8 & 72,8 & 76,5 \\
\hline $\begin{array}{l}\text { Wiem, jak usunąć osoby z mojej listy } \\
\text { kontaktów }\end{array}$ & 74,6 & 70,5 & 78 \\
\hline $\begin{array}{l}\text { Wiem, jakie informacje powinno się } \\
\text { udostępniać, a jakich nie powinno się } \\
\text { umieszczać w internecie }\end{array}$ & 66,2 & 63 & 67 \\
\hline $\begin{array}{l}\text { Wiem, jak zapisać zdjęcie znalezione } \\
\text { w internecie }\end{array}$ & 62,9 & 63 & 62,8 \\
\hline $\begin{array}{l}\text { Wiem, jak zmienić moje ustawienia } \\
\text { prywatności (np. na portalu społeczno- } \\
\text { ściowym) }\end{array}$ & 59,9 & 56,5 & $62,8 * *$ \\
\hline $\begin{array}{l}\text { Wiem, jak robić zakupy przez aplikacje } \\
\text { mobilne }\end{array}$ & 50,7 & 52,2 & 49,5 \\
\hline $\begin{array}{l}\text { Wiem, jak sprawdzać koszty korzysta- } \\
\text { nia z aplikacji mobilnych }\end{array}$ & 49,2 & 54,4 & $44,5 * * *$ \\
\hline
\end{tabular}




\begin{abstract}
Wiem, jak tworzyć i publikować w internecie filmy albo muzykę

39

45,4

$33,4 * * *$

Łatwo mi wybrać najlepsze słowa kluczowe, żeby wyszukać coś w internecie

37,6

40,8

34,8

Łatwo mi sprawdzić, czy informacja, którą znalazłem/am w internecie jest prawdziwa

37,2

$27,4 * *$

Wiem, jak edytować lub zmieniać treści w internecie, które inni stworzyli i za24 29,7 $19 * * *$ mieścili online

$\mathrm{N}=985$ - starsza młodzież 11-17 lat, różnice istotne statystycznie pomiędzy chłopcami i dziewczętami ** $p<0,05$ $* * * p<0,01$

Istotne jest to, że młodzi ludzie nie oceniają powszechnie większości swoich kompetencji cyfrowych wysoko (choć cały czas należy pamiętać, że w tabeli przedstawiono jedynie oceny najwyższe). Ze wszystkich uwzględnionych w badaniu umiejętności respondenci najwyżej oceniali umiejętność instalacji aplikacji na urządzeniach mobilnych oraz usuwania osób z listy znajomych (ok. 3/4 badanej grupy).

Chłopcy w zakresie samooceny nie różnili się istotnie od dziewcząt. Kwestie umiejętności zmiany ustawień w portalu społecznościowym były wyżej oceniane przez dziewczęta, natomiast umiejętności sprawdzania kosztów aplikacji mobilnych, publikowania w internecie filmów lub muzyki, sprawdzania prawdziwości informacji online oraz zmieniania i edytowania treści zamienionych przez innych zostały oceniane wyżej przez chłopców.
\end{abstract}

\title{
Ważny fakt
}

Niewielu młodych ludzi ocenia wysoko kompetencje związane z poszukiwaniem i oceną wiarygodności informacji.

Należy zwrócić uwagę, że w zestawieniu z oceną innych kompetencji respondenci rzadko oceniają wysoko własne umiejętności w zakresie doboru odpowiednich słów kluczowych przy wyszukiwaniu w internecie oraz sprawdzenia, która znaleziona informacja jest prawdziwa. To ważny wynik, gdyż obydwie umiejętności należy zaliczyć do podstawowych kompetencji medialnych niezbędnych do krytycznego wykorzystania informacji dostępnych online. 


\section{Jakie postawy wobec bycia online przejawiają młodzi ludzie?}

W badaniu młodzi ludzie pytani byli o swoje przekonania dotyczące bycia online - tego jak się czują i jak komunikują się z innymi. Takie subiektywne przekonania są istotnym wskaźnikiem roli internetu w życiu młodych osób, gdyż pokazują, jak młodzi użytkownicy widzą rolę tego medium w kontekście swojego funkcjonowania offline.

Tabela 2.5. Postawy młodych ludzi wobec własnego bycia online

\begin{tabular}{|c|c|c|c|c|c|}
\hline Postawy & $\begin{array}{l}\text { Nigdy } \\
\%\end{array}$ & $\begin{array}{c}\text { Czasem } \\
\%\end{array}$ & $\begin{array}{c}\text { Często } \\
\%\end{array}$ & $\begin{array}{c}\text { Zawsze } \\
\%\end{array}$ & $\begin{array}{c}\text { Nie wiem/ Trudno } \\
\text { powiedzieć } \\
\%\end{array}$ \\
\hline $\begin{array}{l}\text { Łatwiej mi być sobą w internecie niż } \\
\text { wtedy, gdy spotykam się z ludźmi } \\
\text { twarzą w twarz }\end{array}$ & 42,3 & 27,8 & 8,8 & 7 & 14,2 \\
\hline $\begin{array}{l}\text { W internecie rozmawiam o innych } \\
\text { rzeczach, niż wtedy, gdy spotykam } \\
\text { się z ludźmi twarzą w twarz }\end{array}$ & 39,1 & 29,1 & 11,7 & 5 & 15,1 \\
\hline $\begin{array}{l}\text { W internecie rozmawiam o spra- } \\
\text { wach osobistych, których nie ujaw- } \\
\text { niam, kiedy rozmawiam z ludźmi } \\
\text { twarzą w twarz }\end{array}$ & 65,3 & 13,9 & 4,7 & 2,3 & 13,8 \\
\hline
\end{tabular}

Generalnie młodzi respondenci, którzy często lub zawsze odczuwali odrębność i specyfikę internetu (na korzyść w porównaniu z byciem offline) są w mniejszości. Mniej niż 16\% czuło (często lub zawsze), że w internecie jest im łatwiej być sobą. Nieco mniej niż 17\% rozmawiało w intenecie o innych rzeczach, niż spotykając się w „realu” twarzą w twarz, a 7\% o sprawach osobistych, których nie poruszali offline. Bardzo wysokie są odsetki młodych ludzi odpowiadających w zakresie każdej z tych kwestii „nigdy”. Wynoszą one odpowiednio ok. 42\%, 39\% i $65 \%$.

\section{Podsumowanie i wnioski}

Nasze badania potwierdziły zaznaczoną już wcześniej tendencję do coraz częstszego wykorzystywania internetu mobilnego. Smartfon i telefon komórkowy są 
najczęstszymi urządzeniami oferującymi mobilny dostęp. Jednocześnie, co trzeba zaznaczyć, mały jest odsetek młodych ludzi, którzy korzystają z internetu stacjonarnie (np. nigdy lub prawie nigdy nie korzysta z komputera stacjonarnego i laptopa ponad 18\% badanych).

To bardzo istotny wynik, szczególnie w kontekście tego, jak rozumiemy bycie online. W czasach, gdy łączenie $z$ internetem powszechnie było stacjonarne, bycie online oznaczało przebywanie w pomieszczeniu, w którym było łącze, a bycie online w znacznym stopniu wyłączało użytkownika z aktywności poza internetem. Internet mobilny radykalnie zmienił sytuację. Bycie online nabrało dzięki niemu wielu innych wymiarów. Po pierwsze, nie jest przyporządkowane do pomieszczenia, gdzie występuje łącze. Zatem być online można właściwie wszędzie. Po drugie, bycie online przeplotło się z innymi podejmowanymi przez użytkownika czynnościami. Ktoś może np. biec w lesie, mając włączoną aplikację zapisującą jego trasę. Jest więc niewątpliwie online - jednak takie bycie nie wyłącza go z innych czynności poza internetem. W niektórych sytuacjach bycie online jest nawet w tle - tak jak w sytuacji, gdy siedząc na spotkaniu z wyciszonym telefonem, jednak wiemy, że możemy otrzymywać wiadomości z komunikatora. Ponadto różne bezpośrednie działania online, bardzo krótkie aktywności, np. sprawdzenie jakiejś informacji, pokazanie komuś zdjęcia, zapłacenie za coś - także istotnie wpływają na percepcję tego, co to znaczy być online zarówno dla samego użytkownika, jak i obserwujących go osób. Jest to z pewnością ważne dla metodyki konstruowania narzędzi do następnych badań, które powinny uwzględniać te zróżnicowane sposoby korzystania z internetu, a nie traktować wykorzystanie jako oczywistą jednolitą grupę czynności, których czas można w prosty sposób sumować.

Zatem interpretując wyniki dotyczące czasu spędzanego online, musimy pamiętać, że czas korzystania, oznacza w rzeczywistości bardzo różne formy obecności, nie tylko działania ekranowe, traktowane standardowo jako korzystanie z internetu.

To przeplatanie się wykorzystania internetu z innymi czynnościami może być też przyczyną wskazanych wyżej stosunkowo wysokich odsetków młodych ludzi, którzy nie chcieli/nie potrafili odpowiedzieć na pytania dotyczące czasu wykorzystania internetu w dni robocze i weekendowe. Respondenci, dla których korzystanie z internetu rzadko jest obecnie wydzieloną czynnością z innych aktywności, mają spore trudności, aby określić taki czas. Zresztą pośrednio taką interpretację potwierdzają zdecydowanie niższe odsetki respondentów, odpo- 
wiadających nie chcę/nie potrafię powiedzieć w innych pytaniach, np. pytaniu dotyczącym urządzeń, za pomocą których respondenci łączą się z internetem. Poważną kwestią jest też to, na ile oszacowania badanych odpowiadają rzeczywistemu czasowi spędzanemu online.

Sama analiza rozkładu korzystania z internetu jest bardzo interesująca. Wbrew obiegowym opiniom sporo młodych ludzi korzysta z internetu stosunkowo krótko - prawie połowa do 2 godzin w dni robocze. Rzeczywiście dłuższe wykorzystanie dotyczy weekendów - tutaj prawie 1/5 starszej młodzieży korzysta 6 godzin lub więcej. Musimy jednak pamiętać, że nie analizujemy tych wyników w zestawieniu z danymi jakościowymi dotyczącymi wykorzystania - są więc one bardzo trudne do interpretacji. Obecne badanie nie pozwala stwierdzić, co w określonym czasie i w jakich proporcjach oznaczało bycie online respondentów. Nie wiemy bowiem, jakie konkretne aktywności zajmowały badanym określony czas.

Potwierdzona została, zaznaczona także w wynikach innych badań, wyraźniejsza tendencja do stacjonarnego łączenia się z internetem przez chłopców (Tanaś i in., 2017). Ma to prawdopodobnie związek z częstszym graniem w gry i gry online przez chłopców, oraz z faktu, że wiele tych gier wymaga prawidłowego działania lepszych/innych parametrów sprzętowych, niż posiada przeciętny smartfon.

Posiadanie konta w portalu społecznościowym okazało się być bardzo częste $(72,6 \%)$, jednak pomimo szerokiego wskaźnika zastosowanego w badaniu (obejmującego np. profile w grach) nie dotyczy ono prawie wszystkich młodych ludzi. Przeczy to stereotypowemu myśleniu, że posiadanie konta w portalu społecznościowym stanowi oczywiste zaangażowanie młodych ludzi i jest społeczną koniecznością (np. wymaganą przez grupę rówieśniczą).

Jednocześnie warto zwrócić uwagę, ze profile takie posiada prawie połowa najmłodszych badanych (9-10 lat). Niewątpliwie zatem ta forma aktywności młodych ludzi powinna być uwzględniona w kontekście działań edukacji medialnej zarówno tych nastawionych na budowanie pozytywnych kompetencji, jak i ochronę przed zagrożeniami (szczególnie w grupie młodszej). W tym ostatnim kontekście warto pamiętać, że znaczny odsetek młodych ludzi nie przestrzega ograniczeń wiekowych i posiada konta w różnych portalach, mimo że są młodsi niż przewidują to regulaminy portali.

Analizując wyniki dotyczące portali społecznościowych, nie należy pomijać zmian w zakresie wykorzystania poszczególnych platform. Badania światowe 
wyraźnie pokazują dynamiczne zmiany w tej kwestii. Najnowsze badania dotyczące amerykańskich nastolatków w wieku 13-17 lat (Pew Research Center, 2018) wskazują, że Facebook jest na czwartym miejscu, jeśli idzie o wykorzystywane przez tę grupę platformy internetowe. Wyprzedzają go YouTube (85\%), Instagram (72\%) i Snapchat (69\%). Młodzi ludzie przenoszą się z jeszcze niedawno „królującego” Facebooka do innych platform, mimo że w całej populacji światowych internautów ten ostatni jest wciąż na pierwszym miejscu (Statista, 2018).

Warto podkreślić, iż odsetki młodych ludzi bardzo wysoko oceniających własne wybrane kompetencje cyfrowe, nie są tak wysokie, jak się często uważa. Szczególnie niska samoocena dotyczy kompetencji związanych z poszukiwaniem i selekcja/weryfikacją informacji zamieszczonych online. Nie należy zatem przeceniać umiejętności młodych ludzi w wykorzystaniu internetu. Powszechnie uważa się, że obecne pokolenie młodych ludzi to użytkownicy internetu, którzy posiadają wiele kompetencji w sposób naturalny. To, że tak nie jest, pokazuje wyraźnie analiza wyników dotyczących samooceny kompetencji. Jest ona z pewnością bardziej optymistyczna w porównaniu z potencjalnym badaniem, gdzie respondenci musieliby wykazać się rzeczywistymi umiejętnościami. Sami młodzi ludzie nie oceniają powszechnie swoich kompetencji bardzo wysoko. Tego typu diagnozy dostarczają przesłanek do analizy zawartości programów edukacji medialnej kierowanych do różnych grup młodych ludzi.

Wreszcie, warto spojrzeć na rozkład przekonań dotyczących bycia online, który przedstawiliśmy w tym rozdziale. Okazuje się, że odsetki młodych ludzi, którzy wskazują na specyfikę swojego samopoczucia online i komunikacji online są niższe niż tych, którzy nie dostrzegają u siebie zmiany zachowania w relacjach z innymi użytkownikami internetu. I tak, jedynie około 16\% młodych ludzi uważa, że często lub zawsze jest im łatwiej być sobą online. Podobny odsetek twierdzi, że w internecie rozmawiają o innych sprawach niż twarzą w twarz. Wreszcie jedynie około 6\% jest zdania, iż rozmawiając online porusza sprawy osobiste, których nie porusza poza internetem. Wyniki te stoją w sprzeczności z poglądem, że życie młodych ludzi masowo przenosi się do sieci, gdzie czują się oni i komunikują lepiej niż poza internetem. Powinniśmy zatem pozbyć się funkcjonującej wciąż dychotomii w myśleniu o funkcjonowaniu młodych ludzi online i offline. 



\section{Aktywność młodych ludzi w internecie}

Łukasz Tomczyk (Uniwersytet Pedagogiczny im. Komisji Edukacji Narodowej w Krakowie)

Obecnie coraz częściej badacze zajmujący się tematyką socjalizacji zapośredniczonej przez nowe media zwracają uwagę na szanse i możliwości, jakie daje konstruktywne użytkowanie internetu. Paradygmat ryzyka uzupełniany jest przez paradygmat szans, a więc podkreślenie pozytywnych możliwości, wynikających ze specyfiki internetu (Livingstone i in., 2017; Pyżalski, 2016; Potyrała, 2017). Jacek Pyżalski (2017), analizując zagadnienie pozytywnego wykorzystania nowych mediów, zwraca szczególną uwagę na fakt konstruktywnego użytkowania mediów cyfrowych, który staje się czynnikiem chroniącym przed zachowaniami ryzykownymi. Pozytywne wykorzystanie internetu sprzyja budowaniu kontaktów z innymi osobami o podobnych zainteresowaniach, umożliwia wymianę informacji ważnych w perspektywie rozwoju osobistego, jest szansą na wyrażanie siebie i autokreację, a także tworzenie nowych relacji. Dlatego szczególnie istotne jest kształtowanie kompetencji cyfrowych odnoszących się nie tylko do sfery rozrywkowej i komunikacyjnej, lecz również konstruktywnego użytkowania mediów cyfrowych. W tabeli nr 3.1 zaprezentowano listę aktywności, ukazującą obszary wykorzystania mediów cyfrowych w grupie młodych użytkowników. Wskazania odnoszą się do kwestii: pozyskiwania informacji i uczenia się w trybie online, uczestniczenia w debatach i ważnych działaniach prospołecznych, aktywności w procesie twórczym, komunikacji, rozrywki, zdrowia, rozwijania hobby, robienia zakupów online. 
Tabela 3.1. Pozytywna aktywność młodych osób w internecie w ciągu ostatniego miesiąca

\begin{tabular}{|c|c|c|c|c|c|c|c|c|c|}
\hline & Lista aktywności & $\begin{array}{c}\text { Nigdy } \\
\%\end{array}$ & $\begin{array}{l}\text { Prawie } \\
\text { nigdy } \\
\%\end{array}$ & $\begin{array}{c}\text { Przynaj- } \\
\text { mniej raz } \\
\text { w tygodniu } \\
\%\end{array}$ & $\begin{array}{c}\text { Codzien- } \\
\text { nie lub } \\
\text { prawie } \\
\text { codziennie } \\
\%\end{array}$ & $\begin{array}{c}\text { Kilka razy } \\
\text { dziennie } \\
\%\end{array}$ & $\begin{array}{c}\text { Prawie } \\
\text { cały czas } \\
\%\end{array}$ & $\begin{array}{c}\text { Nie wiem } \\
\text { + Wolę nie } \\
\text { odpowia- } \\
\text { dać } \\
\%\end{array}$ & Różnice \\
\hline a) & $\begin{array}{l}\text { Szukałem/am in- } \\
\text { formacji dotyczą- } \\
\text { cych możliwości } \\
\text { pracy/nauki }\end{array}$ & 11,9 & 22,2 & 35,1 & 13,6 & 4,0 & 3,5 & 9,7 & $\begin{array}{l}\text { Starsi czę- } \\
\text { ściej****}\end{array}$ \\
\hline b) & $\begin{array}{l}\text { Używałem/am } \\
\text { internetu do } \\
\text { nauki } \\
\text { w szkole }\end{array}$ & 25,2 & 20,9 & 30,4 & 11,1 & 3,6 & 2,0 & 6,7 & $\begin{array}{l}\text { Dziewczęta } \\
\text { częściej** } \\
\text { Starsi czę- } \\
\text { ściej**** }\end{array}$ \\
\hline c) & $\begin{array}{l}\text { Używałem/am } \\
\text { internetu do } \\
\text { rozmowy } \\
\text { z ludźmi z innych } \\
\text { krajów }\end{array}$ & 52,9 & 19,2 & 10,8 & 6,8 & 3,0 & 2,1 & 5,1 & $\begin{array}{c}\text { Dziewczęta } \\
\text { częściej**** } \\
\text { Starsi } \\
\text { częściej**** }\end{array}$ \\
\hline d) & $\begin{array}{l}\text { Szukałem/am } \\
\text { informacji z kraju } \\
\text { i ze świata w in- } \\
\text { ternecie }\end{array}$ & 24,7 & 26,3 & 27,1 & 9,4 & 3,4 & 1,7 & 7,4 & $\begin{array}{c}\text { Dziewczęta } \\
\text { częściej* } \\
\text { Starsi } \\
\text { częściej**** }\end{array}$ \\
\hline e) & $\begin{array}{l}\text { Włączyłem/am } \\
\text { się w kampanię/ } \\
\text { protest albo pod- } \\
\text { pisałem petycję } \\
\text { online }\end{array}$ & 79,5 & 9,8 & 3,0 & 0,9 & 0,5 & 0,3 & 5,9 & $\begin{array}{c}\text { Dziewczęta } \\
\text { częściej** } \\
\text { Starsi } \\
\text { częściej**** }\end{array}$ \\
\hline f) & $\begin{array}{l}\text { Dyskutowałem/ } \\
\text { am online w in- } \\
\text { nymi osobami na } \\
\text { tematy społeczne } \\
\text { lub polityczne }\end{array}$ & 72,4 & 11,4 & 6,5 & 2,5 & 1,5 & 0,5 & 5,3 & $\begin{array}{l}\text { Dziewczęta } \\
\text { częściej** } \\
\text { Starsi } \\
\text { częściej**** }\end{array}$ \\
\hline g) & $\begin{array}{l}\text { Przygotowałem/ } \\
\text { am własne video } \\
\text { lub muzykę } \\
\text { i udostępniłem/ } \\
\text { am online }\end{array}$ & 68,3 & 16,3 & 6,2 & 2,2 & 1,1 & 0,6 & 5,3 & $\begin{array}{c}\text { Chłopcy } \\
\text { częściej**** }\end{array}$ \\
\hline h) & $\begin{array}{l}\text { Odwiedzałem/ } \\
\text { am portal spo- } \\
\text { łecznościowy }\end{array}$ & 25,3 & 7,8 & 12,2 & 21,6 & 17,5 & 10,2 & 5,4 & Brak różnic \\
\hline
\end{tabular}




\begin{tabular}{|c|c|c|c|c|c|c|c|c|}
\hline $\begin{array}{l}\text { i) Komunikowałem/ } \\
\text { am się z rodziną } \\
\text { lub przyjaciółmi }\end{array}$ & 8,3 & 8,7 & 16,9 & 28,9 & 18,5 & 13,0 & 5,7 & $\begin{array}{c}\text { Starsi } \\
\text { częściej**** }\end{array}$ \\
\hline $\begin{array}{l}\text { j) Grałem/am w gry } \\
\text { online (sam/a) }\end{array}$ & 18,2 & 18,7 & 24,7 & 18,3 & 9,6 & 5,1 & 5,4 & $\begin{array}{c}\text { Starsi } \\
\text { częściej**** }\end{array}$ \\
\hline $\begin{array}{l}\text { k)nOglądałem/am } \\
\text { filmiki }\end{array}$ & 4,0 & 6,3 & 18,6 & 33,9 & 21,6 & 9,9 & 5,7 & Brak różnic \\
\hline $\begin{array}{l}\text { I) Słuchałem/am } \\
\text { muzyki online }\end{array}$ & 8,1 & 8,8 & 15,9 & 27,9 & 19,1 & 14,5 & 5,8 & Brak różnic \\
\hline $\begin{array}{l}\text { m) Uczestniczyłem/ } \\
\text { am w grupie on- } \\
\text { line, gdzie ludzie } \\
\text { dzielą się swoimi } \\
\text { zainteresowania- } \\
\text { mi/hobby }\end{array}$ & 48,7 & 16,3 & 12,2 & 9,8 & 4,5 & 3,2 & 5,4 & $\begin{array}{c}\text { Dziewczęta } \\
\text { częściej**** } \\
\text { Starsi } \\
\text { częściej**** }\end{array}$ \\
\hline $\begin{array}{l}\text { n) Szukałem/am in- } \\
\text { formacji na temat } \\
\text { zdrowia potrzeb- } \\
\text { nych mi lub komuś } \\
\text { kogo znam }\end{array}$ & 45,3 & 26,5 & 13,1 & 4,6 & 1,9 & 1,1 & 7,4 & Brak różnic \\
\hline $\begin{array}{l}\text { o) Szukałem/am } \\
\text { czegoś do kupie- } \\
\text { nia lub informacji, } \\
\text { ile coś kosztuje }\end{array}$ & 15,3 & 21,9 & 33,4 & 13,5 & 5,2 & 4,0 & 6,8 & $\begin{array}{c}\text { Starsi } \\
\text { częściej**** }\end{array}$ \\
\hline
\end{tabular}

Najczęściej internet wykorzystywany jest przez młodzież do celów rozrywkowych (np. oglądanie filmów, użytkowanie portali społecznościowych). Dominacja ludyczności w użytkowaniu przez młode osoby została dostrzeżona nie tylko w ramach EU KIDS Online, lecz także innych opracowaniach, ukazujących style użytkowania internetu wśród młodych osób (Tanaś i in., 2017). Równie często media cyfrowe użytkowane są w celu wyszukiwania informacji (ponad 40\% nastolatków wyszukuje informacje ze świata minimum raz w tygodniu lub częściej). Również co trzeci nastolatek porównuje informacje dotyczące cen minimum raz $w$ tygodniu. Ponad połowa ankietowanych czerpie wiedzę na temat zdrowia z sieci. Zdecydowanie najczęściej usługi internetowe wykorzystywane są do komunikacji z bliskimi oraz rodziną, jedynie nieco ponad 8\% nie używa mediów cyfro- 
wych w tym celu. W aspekcie komunikacyjnym najrzadziej internet stosowany jest do wyrażania sprzeciwu - np. podpisywania petycji online, czy też dyskusji na tematy społeczne i polityczne. Niemalże połowa młodych osób komunikowała się z internautami z innych krajów w ciągu ostatniego miesiąca. Systematycznie, co dziesiąty nastolatek dzieli się utworami muzycznymi lub filmami. Na podstawie zgromadzonych danych należy podkreślić, że badana młodzież wykorzystuje internet przede wszystkim do zaspokajania potrzeb komunikacyjnych, informacyjnych oraz rozrywkowych. Dziewczęta nieco częściej wykorzystują systematycznie internet w celach związanych ze szkołą i rozmowami online, z kolei chłopcy chętniej zajmują się udostępnianiem własnej muzyki lub filmów online. Wraz z wiekiem wzrasta intensywność wykorzystywania możliwości mediów cyfrowych. Należy zatem wyraźnie zaznaczyć, że większość popularnych usług internetowych jest o wiele częściej wykorzystywana w starszych grupach wiekowych niż w młodszych. Związane jest to z kilkoma czynnikami, m.in.: poziomem kompetencji cyfrowych, wiedzą na temat możliwości mediów cyfrowych, częstotliwością użytkowania mediów cyfrowych oraz potrzebami użytkowników.

\section{Ważny fakt}

Najczęściej - codziennie lub prawie codziennie, młode osoby wykorzystują internet do użytkowania portali społecznościowych, komunikacji, gier, słuchania muzyki i oglądania filmów. Najrzadziej ankietowani wykorzystują internet w celu protestowania, dzielenia się własną twórczością, prowadzenia dyskusji na ważne tematy społeczne lub polityczne, czy też uczestniczenia w społecznościach internetowych rozwijających hobby. W badanych grupach dominuje zatem wykorzystanie rozrywkowo-komunikacyjne. Istnieją również różnice pomiędzy chłopcami i dziewczętami w wybranych obszarach użytkowania mediów cyfrowych. Wraz z wiekiem wzrasta intensywność wykorzystywania usług i stron internetowych.

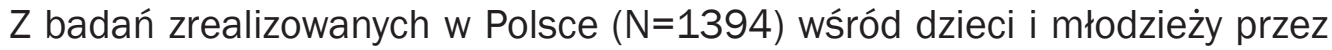
zespół NASK można zauważyć, że nowe technologie w tej grupie wiekowej najczęściej wykorzystywane są (codziennie lub kilka razy w tygodniu - wartości 
przekraczające $60 \%$ punktów procentowych deklaracji w próbie) do: odrabiania lekcji, poszerzania wiedzy potrzebnej do szkoły, przygotowania do sprawdzianów, wzmacniania zainteresowań, korzystania z portali społecznościowych, wyszukiwania informacji, rozwijania kontaktów ze znajomymi, celów rozrywkowych (Tanaś i in., 2017). Internet dla młodych osób to przede wszystkim kolejny kanał informacyjny, posiadający paletę różnorodnych aplikacji i stron internetowych, służących szybkiej wymianie informacji, ale również źródło wspomagające procesy związane z uczeniem się i rozrywką. Badania EU KIDS Online i NASK są w tym obszarze spójne.

Badania prowadzone w ostatnich latach w Europie potwierdzają, że dzieci i młodzież używają technologii cyfrowych głównie do zabawy, nauki i komunikowania się z innymi. Większość z nich ma pozytywne doświadczenia online (Wespieser, 2015). Internet, podobnie jak i inne narzędzia technologiczne, cechuje się dualnym charakterem (Ziemba, 2013). Negatywne sposoby wykorzystania technologii wzbudzają niepokój osób znaczących w procesie wychowania (głównie rodziców i nauczycieli), przysłaniając jednocześnie pozytywne następstwa wynikające z aktywności online. Internet analogicznie jak i inne przestrzenie, w których funkcjonują młode osoby, może przyczyniać się do aktywnej partycypacji przynoszącej pozytywne skutki (Stosic, Stosic, 2015). W sieci, podobnie jak w przestrzeni offline, młodzież poszukuje informacji o okolicy, w której mieszka, pomaga innym (Davis, 2011), aktywnie komunikuje się (Moawad, Ebrahem, 2016), uczy obsługi nowych technologii osoby starsze (Tomczyk, 2015), wyraża zdanie na temat innych osób lub sytuacji (Middaugh, Schofield, Clark, Ballard, 2017), dzieli się informacjami, tworzy, sprzedaje i kupuje. Korzystanie $z$ internetu bywa często $w$ tej grupie postrzegane jako biernie spędzany czas wolny, podczas gdy w badaniach EU KIDS Online skoncentrowano się na konstruktywnym wykorzystaniu mediów cyfrowych nie tylko dla realizacji własnych zadań, lecz również w celu pomocy innym osobom. W tabeli numer 3.2 zaprezentowano procentowy rozkład odpowiedzi związanych aktywnym wykorzystaniem ICT. 
Tabela 3.2. Pozytywne wykorzystanie mediów cyfrowych młodych osób w internecie w ciągu ostatniego miesiąca

\begin{tabular}{|c|c|c|c|c|c|c|c|c|}
\hline Lista aktywności & $\begin{array}{c}\text { Nigdy } \\
\%\end{array}$ & $\begin{array}{c}\text { Prawie } \\
\text { nigdy } \\
\%\end{array}$ & $\begin{array}{c}\text { Przynaj- } \\
\text { mniej raz } \\
\text { w tygodniu } \\
\%\end{array}$ & $\begin{array}{c}\text { Codziennie } \\
\text { lub prawie } \\
\text { codziennie } \\
\%\end{array}$ & $\begin{array}{c}\text { Kilka razy } \\
\text { dziennie } \\
\%\end{array}$ & $\begin{array}{c}\text { Prawie cały } \\
\text { czas } \\
\%\end{array}$ & $\begin{array}{l}\text { Nie wiem } \\
\text { + Wolę nie } \\
\text { odpowia- } \\
\text { dać } \\
\%\end{array}$ & Różnice \\
\hline
\end{tabular}

a) Szukałem/am informacji na temat tego, co się dzieje \begin{tabular}{l|l|l}
42,3 & 29,6 & 16,8
\end{tabular}

3,3

1,1

0,5

6,4

Starsi w okolicy, w której mieszkam

b) Skorzystałem/am z internetu, aby komuś pomóc

33,1

25,1
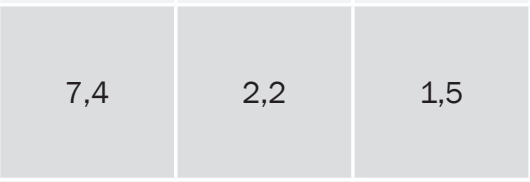

8,5

c) Wysyłałem/am i odbierałem/am wiadomości

19,2 13,0

16,2

19,8

15,6

9,6

6,7

Dziewczęta
częściej**
Starsi
częściej****

d) Pomogłem/am komuś, kto potrzebował albo chciał skorzystać z internetu
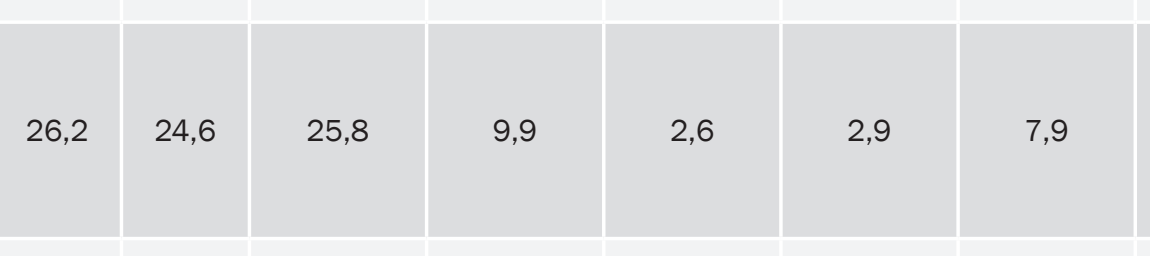

Dziewczęta

e) Skomentowałem/ am coś, co moi znajomi albo rodzina 39,5 18,2

19,5

9,3

3,6

3,3

6,6

częściej**** opublikowali w internecie

f) Pokazałem/am komuś ze znajomych albo z rodziny coś, co widziałem/am w internecie
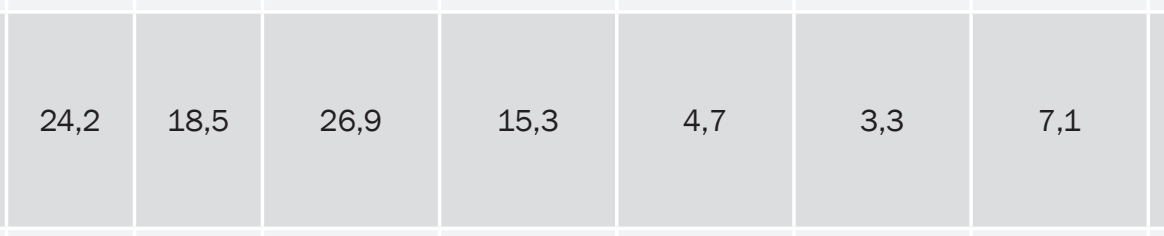

Starsi częściej****

g) Grałem/am w gry online sam/a 38,0

21,6

16,9

9,9

3,9

3,0

\section{6,7}
Dziewczęta częściej* Starsi częściej****

h) Grałem/am w gry online $z$ innymi osobami

\begin{tabular}{l|l|l|}
\hline 37,9 & 19,7 & 16,9 \\
\hline
\end{tabular}

11,7

4,6

3,3

\section{Dziewczęta częściej** \\ Starsi częściej****}

\section{Dziewczęta częściej* * Starsi częściej****}

Chłopcy częściej****

Chłopcy
częściej****




\begin{tabular}{|c|c|c|c|c|c|c|c|c|}
\hline $\begin{array}{l}\text { i)nOglądałem w interne- } \\
\text { cie programy telewi- } \\
\text { zyjne, filmy albo bajki }\end{array}$ & 32,8 & 17,5 & 17,8 & 14,9 & 6,6 & 3,7 & 6,7 & $\begin{array}{l}\text { Dziewczęta } \\
\text { częściej** } \\
\text { Starsi } \\
\text { częściej**** }\end{array}$ \\
\hline $\begin{array}{l}\text { j) Korzystałem/am } \\
\text { z aplikacji mobilnych } \\
\text { (na telefonie lub } \\
\text { tablecie) }\end{array}$ & 20,8 & 13,4 & 18,7 & 22,0 & 9,7 & 7,7 & 7,7 & $\begin{array}{c}\text { Starsi } \\
\text { częściej**** }\end{array}$ \\
\hline $\begin{array}{l}\text { k) Umieszczałem/am } \\
\text { w internecie filmy } \\
\text { (filmiki) albo muzy- } \\
\text { kę, której autorem } \\
\text { był ktoś inny niż ja }\end{array}$ & 75,5 & 8,1 & 4,6 & 2,9 & 1,4 & 1,2 & 6,2 & Brak różnic \\
\hline $\begin{array}{l}\text { I) Stworzyłem/am coś } \\
\text { przy pomocy aplikacji } \\
\text { mobilnej (np. naryso- } \\
\text { wałem/am obrazek } \\
\text { na telefonie/tablecie) }\end{array}$ & 57,4 & 19,2 & 9,5 & 4,3 & 1,7 & 1,2 & 6,6 & Brak różnic \\
\hline $\begin{array}{l}\text { m) Zrobiłem/am zdję- } \\
\text { cie albo obrazek, } \\
\text { które umieściłem/ } \\
\text { am w internecie, } \\
\text { aby podzielić się } \\
\text { z innymi }\end{array}$ & 50,3 & 17,9 & 14,9 & 5,2 & 2,2 & 2,4 & 7,1 & $\begin{array}{l}\text { Dziewczęta } \\
\text { częściej*** } \\
\text { Starsi } \\
\text { częściej**** }\end{array}$ \\
\hline $\begin{array}{l}\text { n) Próbowałem/am coś } \\
\text { sprzedać w internecie }\end{array}$ & 71,7 & 13,9 & 4,1 & 2,1 & 1,0 & 1,0 & 6,2 & Brak różnic \\
\hline $\begin{array}{l}\text { o) Kupiłem/am coś } \\
\text { w internecie }\end{array}$ & 46,6 & 23,0 & 14,0 & 3,9 & 1,1 & 1,8 & 9,6 & $\begin{array}{c}\text { Starsi } \\
\text { częściej**** }\end{array}$ \\
\hline
\end{tabular}

$\mathrm{N}=996$ - młodzi ludzie w wielu 11-17 lat, * $\mathrm{p}<0,05 ;{ }^{*} \mathrm{*}<<0,01 ; * *^{*} \mathrm{p}<0,001,{ }^{*} * *{ }^{*} \mathrm{p}<0,0001$

Intensywne użytkowanie nowych mediów, a więc wykonywanie pewnych czynności minimum raz w tygodniu lub częściej, dotyczy zazwyczaj: korzystania z aplikacji mobilnych, wysyłania i odbierania informacji (ok. 60\%), współdzielenia się informacjami znalezionymi w sieci z najbliższymi osobami (ponad połowa ankietowanych). Przeszło 16\% nastolatków komentuje codziennie materiały umieszczone w sieci przez osoby bliskie; co czwarty gra systematycznie minimum raz w tygodniu lub częściej w gry sieciowe; również co czwarty pomaga innym osobom mającym problemy z obsługą mediów cyfrowych. Trzy na dziesięć osób, minimum raz w tygodniu korzysta z internetu, aby pomóc drugiej osobie (sprawy problematyczne nie muszą dotyczyć mediów cyfrowych). 
Młode osoby najrzadziej wykorzystują sieć do umieszczania filmów i materiałów audio innych osób (ponad 2/3 młodych osób nie podjęło takiej czynności), sprzedaży produktów (ponad 71\% nie miało tego typu doświadczeń). Ponad połowa badanych nie stworzyła niczego przy pomocy aplikacji mobilnej oraz nie dzieliła się zdjęciami lub grafiką własnego autorstwa w ciągu ostatniego miesiąca. Niemalże co drugi młody internauta nigdy nie dokonał zakupu w sieci oraz nie poszukiwał informacji na temat własnej okolicy, nie grał też online. Chłopcy na przestrzeni ostatniego miesiąca o wiele częściej grali samodzielnie oraz z innymi osobami niż dziewczęta. Z kolei dziewczęta nieco częściej niż chłopcy wykorzystywały internet do wysyłania i odbierania wiadomości, pomagania innym, komentowania postów znajomych lub rodziny oraz umieszczania własnych zdjęć w sieci. W większości przypadków wraz z wiekiem wzrasta częstotliwość wykorzystywania mediów cyfrowych. Zależność pomiędzy wiekiem a intensywnością korzystania nie jest prawdziwa dla użytkowania gier komputerowych, procesu twórczego oraz prób sprzedaży internetowej. Fenomen braku zależności pomiędzy wiekiem a publikowaniem w internecie własnej twórczości można tłumaczyć m.in. popularnością youtuberów, którzy stają się wzorem do naśladowania dla młodego pokolenia. Ponadto umieszczanie własnych zdjęć, filmów, muzyki jest czynnością niewymagającą specjalistycznej wiedzy informatycznej, ponieważ serwisy hostingowe lub strumieniowego przesyłania danych są intuicyjne w obsłudze dla młodego pokolenia. Wymienione udogodnienia są czynnikami sprzyjającymi podejmowaniu aktywności online, chociaż niewarunkującymi w pełni konstruktywnego wykorzystania internetu.

\section{Ważny fakt}

Najczęściej młodzież, użytkując internet, korzysta z aplikacji mobilnych, wysyła i odbiera wiadomości oraz dzieli się informacjami znalezionymi w sieci z najbliższymi osobami. Najrzadziej ICT wykorzystywane są w sposób twórczy - np. w celu stworzenia czegoś przy pomocy aplikacji mobilnej. Około połowa młodych osób nie dokonała zakupu przez internet w ciągu ostatniego miesiąca oraz nie poszukiwała informacji na temat najbliższego otoczenia. Istnieją różnice ze względu na płeć w stylach użytkowania internetu (chłopcy o wiele częściej grają, natomiast dziewczęta pomagają, komunikują się, komentują posty i umieszczają własne zdjęcia). Wraz z wiekiem wzrasta częstotliwość wykorzystywania mediów cyfrowych. 
Młodzi użytkownicy internetu posiadają świadomość pozytywnych możliwości tkwiących w nowych mediach (Zilka, 2017). Jak wynika z krakowskich badań $(\mathrm{N}=706$, młodzież gimnazjalna i ponadgimnazjalna), użytkując nowe technologie adolescenci najczęściej wybierają bierne formy użytkowania mediów sieciowych. Współwystępowanie to zostało również potwierdzone przez analizę danych zgromadzonych w ramach EU Kids Online. Z kolei najbardziej intensywne użytkowanie internetu dotyczy najczęściej: obsługi portali społecznościowych, użytkowania komunikatorów, oglądania filmów i teledysków, słuchania muzyki, poszukiwania informacji (Solecki, 2017). Odbiór treści i komunikatów jest o wiele częstszą postawą niż aktywna partycypacja w przestrzeni medialnej. Czynnikiem, który warunkuje aktywne wykorzystanie możliwości internetu jest przede wszystkim wiek. Starsi adolescenci częściej wykorzystują w sposób kreatywny nowe technologie niż młodsi użytkownicy. Założenie to potwierdziły również wyniki badań zgromadzone na próbie 10,930 adolescentów w przedziale wiekowym 14-17 lat w sześciu europejskich krajach (Grecji, Hiszpanii, Rumunii, Holandii, Polsce oraz Islandii) (Tsitsika i in., 2014). Analogiczną tendencję zaobserwowano w ramach obecnych wyników EU Kids Online PL. 



\title{
4. Internet w szkole
}

\author{
Jacek Pyżalski (Uniwersytet im. Adama Mickiewicza w Poznaniu)
}

Często jako pewnik przyjmuje się, że wprowadzenie do szkoły internetu, czy szerzej urządzeń cyfrowych, uczyni ją nowoczesną i generalnie lepszą. W rzeczywistości jednak, wynikające z tego korzyści nie są wcale takie oczywiste, a ich obecność zależy także od innych kwestii, niż wyposażenie szkół w sprzęt i łącze internetowe (por. Dylak, 2012; Hojnacki i in., 2011; Klus-Stańska, 2013; Koehler, Mishra, 2009, Polskie Bractwo Kawalerów Gutenberga, 2013). Zagadnienia te zostaną omówione dokładniej w dalszej części rozdziału.

Analizując kwestie cyfryzacji szkoły, mamy na myśli nie tylko sam internet. Technologie informacyjno-komunikacyjne to zbiór znacznie większy, dlatego w tym rozdziale przywołujemy literaturę obejmującą szerszy zakres technologii cyfrowych. Jednocześnie warto podkreślić tendencję do konstruowania technologii edukacyjnych w taki sposób, że wykorzystują one możliwości komunikacji przez internet oraz zasoby cyfrowe dostępne online.

Sonia Livingstone (2012) wskazuje, że politycy, przedsiębiorcy produkujący sprzęt i oprogramowanie oraz rodzice wychodzą z założenia, iż cyfrowe rozwiązania edukacyjne na różnych poziomach są tak ważne dla nauczania/uczenia się, jak w XIX wieku książka.

To zgeneralizowane założenie przekłada się często na pozbawione głębszego namysłu wprowadzanie ich do instytucji edukacyjnych. 
Okazuje się jednak, że empiryczna weryfikacja tego pozornie oczywistego założenia, dotyczącego korzyści wynikających z wprowadzania takich technologii, przynosi ciekawe i czasami bardzo zaskakujące rezultaty.

Wystarczy przeanalizować wyniki, które zostały przedstawione w 2015 roku w raporcie OECD: Students, Computers and Learning. Making the connection, bazującym na badaniach PISA (Programme for International Student Assessment). Jego wyniki potwierdziły, że prawie 3/4 uczniów w badanych krajach korzystało z komputera stacjonarnego/laptopa/tabletu w szkole w ramach zajęć.

Okazało się jednak, że ci, którzy używają komputerów w szkołach uzyskiwali jedynie nieco lepsze wyniki niż osoby używające ich rzadko. Jednocześnie uczniowie bardzo często korzystający z komputerów w szkole, mieli w większości wskaźników niższe wyniki edukacyjne (OECD, 2015). Takie niejednoznaczne rezultaty dotyczące związków wykorzystania technologii informacyjno-komunikacyjnych pojawiają się w wielu projektach badawczych (por. Livingstone, 2012). Warto zastanowić się, z czego wynika ten brak przełożenia wprowadzenia technologii i jakości edukacji.

Z perspektywy pedagogicznej możemy przyjąć przynajmniej kilka interpretacji. Po pierwsze, wskazuje się, iż ważniejsze niż wykorzystanie technologii informacyjno-komunikacyjnych, głównie internetu, jest to, jak pod względem edukacyjnym jest ona wykorzystywana. Liczy się jakość jej zastosowania, powiązana bezpośrednio z kompetencjami nauczycieli, którzy muszą umieć z takich narzędzi korzystać w swojej codziennej aktywności zawodowej. Chodzi tu oczywiście nie tylko o techniczną obsługę urządzeń czy oprogramowania, ale znacznie szerszą wiedzę profesjonalną, która jest niezbędna do tego, aby wybór technologii i sposób ich zastosowania był korzystny pedagogicznie. Niestety, bardzo często myślenie osób cyfryzujących systemowo edukację tych kwestii nie uwzględnia lub czyni to w zbyt małym stopniu. Osoby wprowadzające takie rozwiązania kładą główny nacisk na to, jaką infrastrukturę (np. szybki internet) czy jaki sprzęt (np. tablice multimedialne, tablety, roboty edukacyjne) zakupić dla szkół. Cała sfera społecznego wymiaru wprowadzania technologii (związanego, np. z zakresem komunikacji zapośredniczonej w szkole) oraz postaw i kompetencji uczestników tego procesu jest ignorowana - a to właśnie ona decyduje o tym, czy cyfryzacja szkół będzie mieć rzeczywiste pozytywne przełożenie na jakość ich działania.

Co więcej, niektóre konkretne rozwiązania edukacyjne, np. uczenie programowania, wprowadzane są mało krytycznie, mimo braków pogłębionych dowodów empirycznych na sensowność ich wprowadzania. Z drugiej strony, należy tu wspomnieć, że rzadko finansuje się i publikuje badania, w których w sposób pogłębiony przyglądamy 
się procesom implementacji technologii w szkołach i efektów ich wprowadzania. Zignorowane i zaniedbane pozostają tutaj takie ważne kwestie, jak rozumienie celów wychowania i nauczania, profesjonalne kompetencje cyfrowe nauczycieli i ich przygotowanie do wykorzystania technologii, indywidualizowanie i dostosowanie rozwiązań dla określonych grup uczniów, np. uczniów ze specjalnymi potrzebami edukacyjnymi, czy uczniów w różnym wieku (por. Plichta, 2017; Pyżalski, 2017a). Wreszcie, istotne jest refleksyjne łączenie tradycyjnych rozwiązań dydaktycznych z cyfrowymi. Niestety, coraz częściej jego miejsce zajmuje nieuzasadnione przekonanie o tym, że wykorzystanie narzędzi cyfrowych jest zawsze korzystniejsze, bez względu na jakość jego wprowadzania (por. Dylak, 2012).

Sami autorzy cytowanego wcześniej raportu OECD (2015) definiują następujące przyczyny niewielkiego związku inwestowania w technologie cyfrowe w szkołach z wynikami w nauce:

- Przecenia się kompetencje cyfrowe głównych aktorów procesu: uczniów i nauczycieli. Na wyrost uważa się, że będą oni umieli kompetentnie wykorzystać technologie w środowisku edukacyjnym.

- Technologie mogą zakłócać relacje międzyludzkie, wraz z kluczową relacją nauczyciel-uczeń. To z kolei może być przeszkodą dla budowania głębokiego, koncepcyjnego rozumienia treści edukacyjnych.

- Brak powszechnej akceptacji prawidłowości, że technologie cyfrowe przyniosą korzyść tylko wtedy, kiedy będą realizowane w oparciu o dobrze skonstruowane koncepcje pedagogiczne.

- Niewiele jest rozwiązań pedagogicznych, które czynią z technologii skuteczne narzędzia edukacyjne.

- Jakość cyfrowych materiałów edukacyjnych jest niewystarczająca.

Znaczący badacze problematyki wykorzystania technologii cyfrowych w edukacji wskazują na konieczność przeniesienia ciężaru zainteresowania z technicznych aspektów wykorzystania technologii informacyjno-komunikacyjnych w szkole na społeczne praktyki ich zastosowania, zarówno przez uczniów, jak i nauczycieli (Bigum, Bulfin, Johnson, 2015; Selwyn, 2010). Mamy tu na myśli takie analizy, które wyraźnie pokazują, jakie obszary praktyki edukacyjnej technologia rzeczywiście zmieniła, a jakich nie zmieniła wcale lub zmieniła je tylko powierzchownie. W przeciwnym razie możemy znaleźć się w sytuacji, gdzie kontynuujemy zadawanie „banalnych pytań, które służą porównaniu tradycyjnych tablic z tablicami interaktywnymi lub iPadów z książkami, albo analizują korzyści płynące z używania określonego programu" (Bigum, Bulfin, Johnson, 2015, s. 6). Jakie pytania są zatem kluczowe dla wykorzystania nowych mediów (głównie in- 
ternetu) w edukacji szkolnej? Wydaje się, że są to te pytania, które dotyczą potencjału nowych mediów w szkole w kontekście ich związku z relacjami rówieśniczymi i relacjami nauczyciel-uczeń (głównie ze względu na wykorzystanie tzw. komunikacji zapośredniczonej). Interesować nas powinna także kwestia (nie)wykorzystania potencjału nowych mediów przez ucznia, który jest uczącym się podmiotem i może (potencjalnie) dzięki nowym mediom zyskać sporo autonomii w procesie uczenia się. Wreszcie są to pytania o rolę nauczycieli w kontekście wykorzystania internetu przez młodych ludzi. W jakim stopniu mają oni zajmować się ochroną dzieci i młodzieży przed zagrożeniami cyfrowego świata, a w jakim mają pracować z nimi nad wykorzystaniem wychowawczego i dydaktycznego potencjału nowych mediów.

Z tej perspektywy ważne jest rozpoznanie doświadczeń aktorów wykorzystania technologii w szkole, którymi w przypadku obecnych badań są uczniowie. To z ich relacji w naszym badaniu EU Kids Online poznajemy pośrednio praktyki szkół w obszarze wykorzystania technologii informacyjno-komunikacyjnych, głównie internetu. Oczywiście, ze względu na liczbę zagadnień podjętych w badaniu, zakres musiał zostać ograniczony. I tak jednak dysponujemy istotnym materiałem do analizy kwestii cyfryzacji polskich szkół.

Wcześniejsze diagnozy ukazywały dosyć pesymistyczny obraz polskiej szkoły w zakresie wykorzystania nowych technologii (Plebańska, 2017). Wyniki badań nauczycieli wskazywały, że w połowie polskich szkół nie były stosowane żadne technologie cyfrowe. Natomiast tam, gdzie je stosowano, w znacznym stopniu bazowały one na aktywności nauczyciela, który wykorzystuje prezentacje multimedialne lub tablice interaktywne. Tylko połowa polskich szkół korzystała z cyfrowych zasobów edukacyjnych. Wyjątkowo rzadko natomiast wykorzystywane były aplikacje mobilne i e-booki. Z drugiej strony, blisko ośmiu na dziesięciu polskich nauczycieli wskazywało, iż zastosowanie technologii cyfrowych podczas zajęć zwiększa zaangażowanie uczniów. Podobnie zresztą uważała znacząca większość uczniów i rodziców, którzy także byli respondentami w tym projekcie. Wyniki badań nauczycieli nie są tu spójne z wynikami uczniów, którzy w 100\% zadeklarowali korzystanie z technologii cyfrowych w szkole (20\% codziennie, $40 \%$ kilka razy w tygodniu, 40\% raz w tygodniu). Uczniowie potwierdzili natomiast dominującą rolę nauczania frontalnego $z$ wykorzystaniem technologii (gdzie nauczyciel prezentuje multimedialne treści). Warto tu zwrócić uwagę, iż co piaty uczeń przynosił na lekcje własny sprzęt i wykorzystywał go do zajęć zgodnie z koncepcją BOYD (bring your own device) przynieś własne urządzenie. Uczniowie korzystają generalnie z gotowych zasobów cyfrowych, rzadko tworząc swoje własne. Najwyższy wynik w tym zakresie dotyczył tworzenia prezentacji multimedialnych i obejmował jedynie $7 \%$ badanych. Większość 
respondentów nie potrafiła opisać ciekawej lekcji z wykorzystaniem technologii informacyjno-komunikacyjnych, w której brali udział.

Podsumowując, wprowadzanie technologii do szkół ma szanse powodzenia jedynie wówczas, gdy bazuje na wiedzy dotyczącej potrzeb uczniów oraz jasno zdefiniowanej i ugruntowanej empirycznie koncepcji pedagogicznej. Brak takich fundamentów może sprawić, że cyfryzacja środowisk edukacyjnych nie tylko nie przyniesie korzyści, ale wręcz zakłóci ich funkcjonowanie. Jest tak, jak wskazują Bigum, Bulfin, Johnson (2015), że popełniamy spory błąd, używając w stosunku do określonych urządzeń czy oprogramowania takich określeń, jak „technologie edukacyjne”, „uczenie się sieciowe” czy „technologie przyjazne uczeniu się”. Charakterystyki takie nie odnoszą się bowiem do technologii per se, lecz ich zastosowania w określonym kontekście. I to jakość tego zastosowania, a nie sama technologia, powinna wyjść na pierwszy plan.

\section{Do czego uczniowie używają internetu w szkole?}

Respondenci byli pytani o to, jak często używają internetu do określonych czynności w czasie pobytu w szkole. W tabeli 4.1 pokazano odsetki tych, którzy danej czynności nie wykonują w szkole wcale oraz tych, którzy robią określone rzeczy za pomocą internetu przynajmniej raz w tygodniu lub codziennie i częściej. Dodatkowo w tabeli 4.1 przywołano informacje dotyczące porównań dotyczące młodszych (9 i 10 lat) oraz starszych (12-17 lat) uczniów. Tabela przedstawia ranking, na którego początku znajdują się najczęściej podejmowane czynności (najniższy odsetek odpowiedzi „nigdy i prawie nigdy”).

Tabela 4.1. Jak często, kiedy jesteś w szkole, korzystasz z internetu albo wykonujesz wymienione poniżej czynności?

\begin{tabular}{|c|c|c|c|c|}
\hline Podejmowane czynności & $\begin{array}{l}\text { Nigdy } \\
\text { i prawie nigdy } \\
\%\end{array}$ & $\begin{array}{c}\text { Przynajmniej } \\
\text { raz w tygodniu } \\
\%\end{array}$ & $\begin{array}{l}\text { Codziennie } \\
\text { i częściej } \\
\%\end{array}$ & $\begin{array}{c}\text { Porównanie } \\
\text { 9-10 lat } \\
\text { i 12-17 lat } \\
\%\end{array}$ \\
\hline 1. Pisanie czegoś & 39,2 & 29,4 & 13,6 & Starsi częściej* \\
\hline $\begin{array}{l}\text { 2. Ćwiczenie czegoś, czego } \\
\text { się uczę (np. matematyki, } \\
\text { języka obcego albo muzyki) }\end{array}$ & 49,5 & 27,7 & 12,6 & $\begin{array}{c}\text { Brak istotnych } \\
\text { różnic }\end{array}$ \\
\hline $\begin{array}{l}\text { 3. Robienie prac grupowych } \\
\text { z innymi uczniami/uczen- } \\
\text { nicami }\end{array}$ & 58,5 & 23,3 & 6,6 & $\begin{array}{c}\text { Brak istotnych } \\
\text { różnic }\end{array}$ \\
\hline
\end{tabular}




\begin{tabular}{l}
$\begin{array}{l}\text { 4. Komunikowanie się z kimś } \\
\text { przez internet w czasie } \\
\text { pobytu w szkole }\end{array}$ \\
$\begin{array}{l}\text { 5. Przygotowywanie prezen- } \\
\text { tacji }\end{array}$ \\
$\begin{array}{l}\text { 6. Szukanie informacji na } \\
\text { stronie szkoły albo na } \\
\text { szkolnej platformie e-lear- } \\
\text { ningowej }\end{array}$ \\
\hline $\begin{array}{l}\text { 7. Tworzenie rysunków albo } \\
\text { grafiki }\end{array}$
\end{tabular}

Warto zauważyć, że na czele rankingu znajdują się stosunkowo proste aktywności, jak pisanie czegoś lub ćwiczenie określonych umiejętności, z wykorzystaniem instrumentów online. Obydwie te czynności mogą być z powodzeniem podejmowane także przy użyciu technologii informacyjno-komunikacyjnych, które nie wymagają łączenia z siecią.

Inaczej wygląda sytuacja związana z tworzeniem prac grupowych z innymi uczniami/uczennicami. Tutaj sieć wykorzystywana jest do poszukiwania treści dostępnych online, które mogą mieć bardzo różny charakter od profesjonalnych materiałów edukacyjnych począwszy od materiałów dziennikarskich, do treści umieszczanych przez indywidualnych użytkowników. Należy podkreślić, że choć działanie to jest na trzecim miejscu w rankingu, to nie realizuje go w szkole aż sześciu na dziesięciu uczniów. Inne aktywności są jeszcze rzadsze, np. proste czynności związane z komunikacją zapośredniczoną w procesie nauczania-uczenia się w szkole dotyczą bardzo niewielkiego odsetka uczniów. Jedynie dwanaście procent raz w tygodniu lub częściej kontaktuje się z nauczycielami nawet $w$ takich prostych sprawach, jak przesłanie zadania domowe- 
go. Tworzenie lub umieszczanie treści na szkolnym blogu lub forum jest podejmowane często przez mniej niż 8\% uczniów. Oczywiście w wielu przypadkach brak takich aktywności może wynikać nie tylko z braku takiej woli, ale z braku oferowania określonych narzędzi przez szkoły.

\section{Ważny fakt}

Młodsi uczniowie tworzą w szkole częściej rysunki lub grafiki $(p<0,05)$. Codziennie lub prawie codziennie robił to co dziesiąty uczeń w wieku 9-10 lat i tylko co dwudziesty w wieku 11-17 lat.

W pozostałych przypadkach, gdzie zaobserwowano istotne statystycznie różnice, starsi uczniowie wskazywali na częstsze angażowanie się w określone działania w porównaniu z młodszymi.

Prawie co trzeci starszy uczeń często (raz w tygodniu lub częściej) szukał informacji na stronie szkoły albo na szkolnej platformie e-learningowej (w porównaniu z ok. 15\% młodszych uczniów) ( $p<0,001$ ).

Bardzo duże różnice między tymi grupami dotyczą komunikacji online podczas pobytu w szkole. Często korzysta z niej co trzeci starszy uczeń i jedynie co dwudziesty młodszy uczeń. W przypadku komunikacji z nauczycielami odpowiednie odsetki wynoszą ok. $14 \%$ i ok. $6 \%$.

\section{Aktywności nauczycieli związane z edukacją medialną uczniów}

Respondenci byli pytani o to, czy i jak często ich nauczyciele podejmowali określone aktywności z zakresu szeroko rozumianej edukacji medialnej. Warto zauważyć, że uczniowie brali pod uwage jakiegokolwiek nauczyciela ze szkoły bez ograniczenia czasu na odpowiedź. Uzyskane wskaźniki stanowią odsetek uczniów, którzy w ogóle doświadczyli określonych działań z obszaru edukacji medialnej podejmowanych przez nauczycieli. 
Wykres 4.1. Edukacja medialna podejmowana przez nauczycieli (Czy któryś z nauczycieli z Twojej szkoły wykonywał działania wymienione poniżej?)

Ogólnie rozmawiał z Tobą o tym, co byś zrobił/a, gdyby kiedykolwiek coś w internecie Cię zaniepokoiło

Pomógł Ci w przeszłości, kiedy coś w internecie Cię zaniepokoiło

Podpowiadał, jak zachowywać się w stosunku do innych osób w internecie

Wyjaśniał, dlaczego niektóre treści internetowe są dobre a inne złe

Rozmawiał z Tobą o tym, co robisz w internecie

Pomagał Ci, kiedy w internecie coś było trudno zrobić albo znaleźć

Określił zasady mówiące, co możesz robić w internecie w szkole

Zachęcał do korzystania i uczenia się rzeczy

$z$ internetu

Podpowiadał, jak bezpiecznie korzystać z internetu

Często lub bardzo często

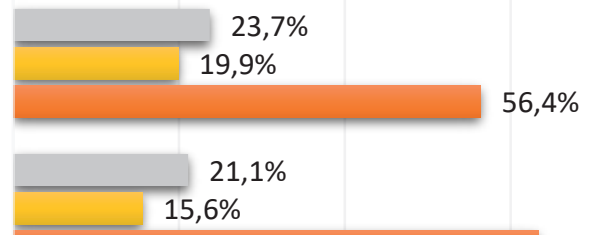

$63,3 \%$

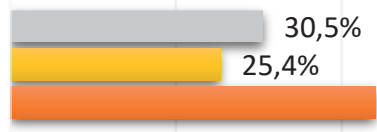

$44,1 \%$

$27,1 \%$

$27,4 \%$

$45,5 \%$

$19,5 \%$

$16 \%$

$28,6 \%$

$24 \%$

$47,4 \%$

$64,5 \%$

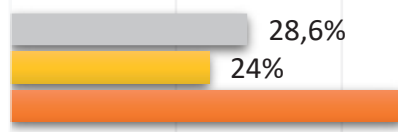

$38,9 \%$

$21,1 \%$

$40 \%$

$31,9 \%$

$23,6 \%$

$44,5 \%$

$41 \%$

$26,3 \%$

$32,7 \%$

Czasami Nigdy lub prawie nigdy

Cała próba z wyłączeniem odpowiadających „nie wiem”, „trudno powiedzieć” lub „wolę nie odpowiadać” (od 23 do $29 \%$ całej próby w poszczególnych kategoriach)

Obraz edukacji medialnej w szkole rzeczywiście jest pesymistyczny, kiedy analizujemy odsetek odpowiedzi „Nigdy lub prawie nigdy”. Okazuje się, że nawet w przypadku bardzo prostych aktywności z zakresu edukacji medialnej wielu uczniów wskazuje, że 
nigdy ich nie doświadczyli. Przykładowo prawie 60\% uczniów twierdzi, że nauczyciel nie rozmawiał z nimi, co robią w internecie.

Podobny odsetek uczniów nie uczestniczył w sytuacji, kiedy nauczyciel rozmawiał z nimi o tym, co ich w internecie zaniepokoiło. Ponad 55\% z nich nie pamięta, by rozmawiało z nauczycielem o tym, co powinni zrobić, gdyby w przyszłości coś zaniepokoiło ich w internecie.

Spoglądając na tę kwestię z drugiej strony, czyli odnosząc się do regularnego realizowania określonych aktywności, sytuacja wygląda podobnie.

Inne wyszczególnione działania realizowane są nieco częściej, ale i tak przeciętnie czterech na dziesięciu badanych wskazuje, że żaden z nauczycieli ich nie podejmował. Najczęstszym regularnie realizowanym działaniem nauczycielskim jest podpowiadanie, jak bezpiecznie korzystać z internetu, ale i tak dotyczy ono tylko ok. 40\% uczniów.

Niektóre działania realizowane w sposób regularny dotyczą tylko co czwartego ucznia (np. zachęcanie do korzystania i uczenia się z internetu) lub co piątego ucznia (np. rozmawianie o tym, co uczniowie robią w internecie).

\section{Zasady i kontrola w zakresie wykorzystania telefonów komórkowych (smartfonów) w szkole}

Istotnym zagadnieniem z punktu widzenia edukacji medialnej jest to, jak szkoły regulują i kontrolują wykorzystanie własnych urządzeń uczniów - telefonów komórkowych i smartfonów, które są, jak wiemy, najczęstszymi urządzeniami dostępowymi, za pomocą których młodzi ludzie łączą się z internetem. Mówimy tu pośrednio o kontrolowaniu wykorzystania internetu w szkole przez własne urządzenia dostępowe uczniów.

Do wprowadzania takich uregulowań upoważnia szkoły prawo oświatowe. Szkoły powinny określać w statucie różne aspekty „przestrzegania warunków wnoszenia i korzystania z telefonów komórkowych i innych urządzeń elektronicznych na terenie szkoły" (Ustawa Prawo Oświatowe, 2017, art. 99, pkt. 4).

Rozwiązania w tym zakresie mogą być różne - od najbardziej radykalnych, czyli całkowitego zakazu przynoszenia i używania takich urządzeń, po ograniczone do minimum liberalne zasady.

Dość zaskakującym wydaje się fakt, że tylko niewiele ponad połowa uczniów wskazuje, iż nauczyciele wyznaczyli zasady dotyczące używania telefonów w szkole. Interpretując ten wynik musimy pamiętać, że to odbiór uczniów. Być może jest tak, że 
w większości szkół, takie zasady są ustalone, ale nie są komunikowane uczniom i egzekwowane. $27 \%$ badanych twierdzi, że nauczyciele sprawdzają, czy telefony komórkowe są wyłączone. Dane te należy rozumieć jako wskaźnik egzekwowania reguł. Wreszcie 1/4 uczniów twierdzi, że nauczyciele zabierają im telefony, gdy łamane są reguły ich użytkowania w szkole, a 6\% stwierdza, że nauczyciele sprawdzają dane w ich telefonach, żeby wiedzieć, co uczniowie robią i z kim się kontaktują.

\section{Sposoby kontroli}

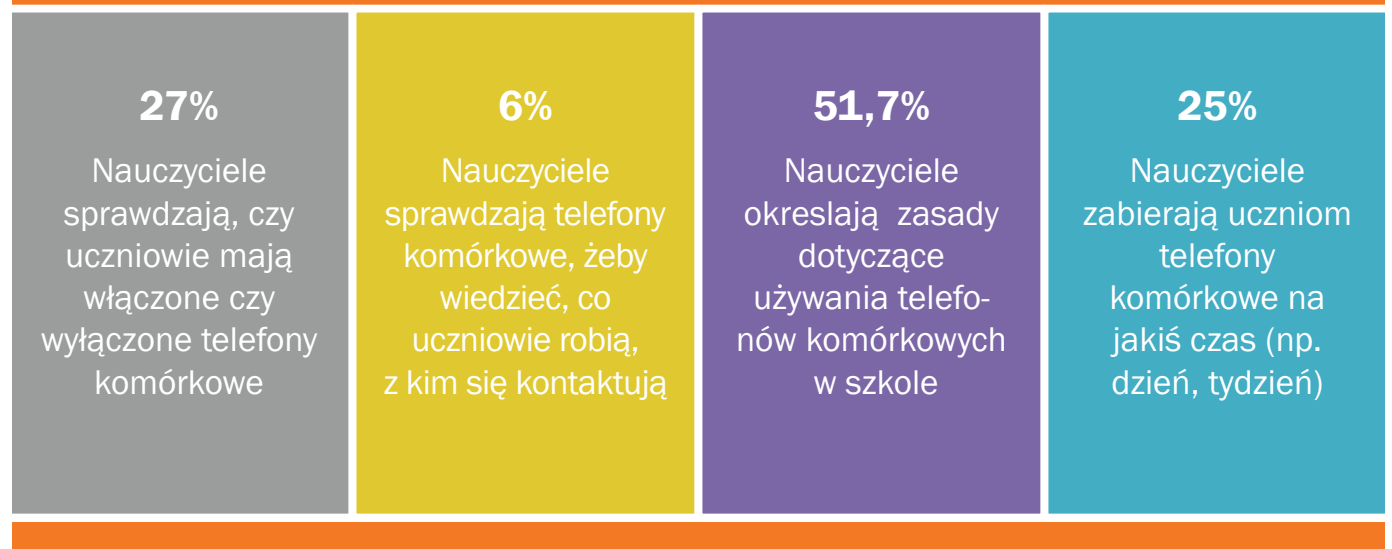

Rys. 4.1. Kontrolowanie wykorzystania telefonów komórkowych/smartfonów w szkołach

\section{Podsumowanie i wnioski}

Uzyskane wyniki potwierdzają wcześniejsze diagnozy dotyczące polskiej szkoły. W ujęciu masowym nie wykorzystuje ona potencjału internetu w procesach dydaktycznych i wychowawczych. Przeważają proste działania, które nie wnoszą żadnej nowej jakości, a stanowią raczej „odświeżenie” tradycyjnych, niekoniecznie najbardziej wartościowych aktywności, np. takich, gdzie uczniowie są biernymi odbiorcami informacji (por. Plebańska, 2017). Rozwiązania wymagające kreowania treści, komunikacji, poszukiwania i oceny wiarygodności informacji są o wiele rzadziej stosowane.

Zaskakująco wielu uczniów wskazało, że żaden nauczyciel nie podejmował z nimi różnych aktywności z zakresu edukacji medialnej. Poważnym problemem jest brak 
działań nawet w bardzo prostych, podstawowych sprawach, jak rozmowa z uczniami o tym, co robią w internecie, czy też rozmowa o sposobach reagowania w przypadku zagrożeń. Wynik ten wyraźnie pokazuje, że inicjatyw z zakresu edukacji medialnej jest ciągle zbyt mało - przynajmniej w obszarze edukacji formalnej. Częściowo lukę tę wypełniają działania, zewnętrznych wobec szkół, organizacji pozarządowych. Wciąż jest jednak wiele do zrobienia w celu przygotowania i motywowania nauczycieli, aby włączali do swoich działań dydaktycznych i wychowawczych treści związane z używaniem internetu przez młodych ludzi. Obecna diagnoza wskazuje, ze w czterech przypadkach na dziesięć kwestia obecności młodego pokolenia w sieci nie znajduje się lub znajduje się w niewielkim zakresie w obszarze zainteresowania szkoły.

Warto zwrócić uwagę, że rzadko realizowane są zarówno te aktywności, które nastawione są na ochronę przed ryzykami, jak i te, które wspierają pozytywne wykorzystanie sieci. Zatem niewystarczająco wspieramy młodych ludzi, aby nie czynili za pomocą internetu zła, ale także za mało uczymy ich budowania dobra.

Osobną ważną kwestią jest regulacja wykorzystania urządzeń cyfrowych w szkole. Należy zauważyć, że o ile racjonalna kontrola w tym zakresie wydaje się konieczna, o tyle całkowity zakaz, z pedagogicznego punktu widzenia, przynosi wiele problemów. Jak bowiem nauczyć młodych ludzi odpowiedzialnego i pozytywnego wykorzystania internetu, jeśli odbierzemy sobie możliwość wspólnego działania w tym obszarze? Poza tym wiele problemów związanych z użytkowaniem internetu poza szkołą i tak przeniesie się na jej grunt, ponieważ dotyczą tej samej populacji (por. Pyżalski, 2012).

Na osobną uwagę zasługuje 1/4 uczniów, którzy wskazują, że nauczyciele odbierają im czasowo telefony, i 6\%, którym nauczyciele sprawdzają ich zawartość. Obydwa te rozwiązania bazują na arbitralnej władzy nauczyciela oraz mogą wiązać się ze sporami prawnymi z rodzicami lub opiekunami dzieci (w momencie zakwestionowania tych rozwiązań). Oczywiście w sytuacjach wyjątkowych działania takie mogą okazać się niezbędne, jednak dalszych badań (szczególnie jakościowych) wymaga sprawdzenie, z jakich sposobów korzystają nauczyciele, by egzekwować rozwiązania w zakresie ograniczania wykorzystania urządzeń cyfrowych w szkołach i uczyć ich przestrzegania.

Wreszcie na koniec warto podkreślić, że obecność i egzekwowanie ograniczeń nie stoi w sprzeczności z wartościowym wykorzystaniem urządzeń własnych ucznia w procesach dydaktycznych i wychowawczych, zgodnych z założeniami podejścia BOYD (bring your own device - przynieś własne urządzenie). Docelowo chodzi przecież o to, aby uczniowie w sposób odpowiedzialny potrafili korzystać z internetu, z którym w większości łączą się wszędzie za pomocą własnych urządzeń. 



\section{Internet w domu}

Aldona Zdrodowska (Ośrodek Przetwarzania Informacji - Państwowy Instytut Badawczy)

Regulowanie dostępu do technologii i nowych mediów, kształtowanie zachowań i postaw wobec nich oraz pośredniczenie między przekazami medialnymi a dzieckiem jest ważną częścią procesu socjalizacji we współczesnej, zdominowanej przez technologię rzeczywistości. Dynamiczny rozwój internetu i upowszechnienie urządzeń mobilnych zmieniło świat społeczny dzieci i nastolatków, w którym często nie potrafią odnaleźć się ich opiekunowie. Tymczasem to na rodziców i opiekunów przede wszystkim spada ciężar odpowiedzialności za przygotowanie dzieci do radzenia sobie w cyfrowym świecie (por. Clark, 2011; Livingstone i Byrne, 2018; Pyżalski, 2013). Przestrzeń wirtualna oferuje młodym i najmłodszym nowe możliwości zdobywania wiedzy, nawiązywania i podtrzymywania relacji społecznych, rozwijania zdolności twórczych, czy po prostu atrakcyjnego spędzania wolnego czasu. Jednak funkcjonowanie w tej dynamicznie zmieniającej się przestrzeni usieciowionych relacji niesie ze sobą ryzyko doświadczania sytuacji zagrażających bezpieczeństwu, samopoczuciu i rozwojowi młodych i najmłodszych internautów.

Działania stosowane przez rodziców w celu zwiększania korzyści i minimalizowania ryzyka dla dziecka korzystającego z internetu (czy ogólniej - mediów oraz technologii informacyjnych i komunikacyjnych) są nazywane w piśmien- 
nictwie anglojęzycznym rodzicielską mediacją korzystania z internetu ${ }^{1}$ (parental mediation of the internet), a po polsku najczęściej ochroną rodzicielską lub praktykami wychowawczymi w zakresie korzystania z internetu. Ochrona rodzicielska może przyjąć różne formy: od informowania o zagrożeniach i sposobach radzenia sobie z nimi, przez stosowanie restrykcji i ograniczeń dotyczących korzystania z sieci, aż po wspólne spędzanie czasu w sieci, rozmawianie o pozytywnych i negatywnych aspektach technologii i wzajemne uczenie się funkcjonowania w nowej, cyfrowej rzeczywistości (Kirwil, 2011; Kirwil, Garmendia, Garitaonandia i Fernandez, 2009; Livingstone i Helsper, 2008; Valkenburg, Piotrowski, Hermanns i de Leeuw, 2013).

Wśród praktyk wychowawczych, stosowanych przez rodziców w celu zapewnienia dziecku bezpieczeństwa w sieci, najczęściej wyróżnia się dwie strategie wspierającą oraz restrykcyjną (por. Livingstone, Ólafsson, Helsper, Lupiáñez, Veltri, i Folkvord, 2017). Pierwsza z nich, tradycyjnie nazywana strategią aktywną, polega na czynnym osobistym wsparciu, udzielanym przez rodzica dziecku korzystającemu z internetu. Do metod wspierających zalicza się np. rozmowę z dzieckiem na temat tego, co robi ono w sieci; informowanie o potencjalnych zagrożeniach i sposobach zapobiegania im oraz radzenia sobie z nimi, a także wspólne korzystanie z technologii. Do tej kategorii należy też tzw. bierne wsparcie, tj. przebywanie w pobliżu dziecka, kiedy korzysta ono z technologii.

Na ochronę przez restrykcje składają się natomiast różnego rodzaju zakazy, nakazy i ograniczenia, m.in. dotyczące czasu korzystania z internetu czy zakresu aktywności, które dziecku wolno podejmować online. Czasem do restrykcyjnych metod ochrony zalicza się także monitorowanie (jawne lub nie) aktywności dziecka w internecie. Rodzice mogą ten rodzaj wsparcia realizować zarówno poprzez rozmowę, jak i z wykorzystaniem narzędzi technologicznych (oprogramowania). Jednak ze względu na specyfikę komunikacji sieciowej (czy to za pomocą komputera czy technologii mobilnych) badacze często proponują wydzielenie, jako osobnej kategorii oddziaływań wychowawczych, działań polegających na stosowaniu przez rodziców rozwiązań technologicznych, służących zwiększaniu bezpieczeństwa dziecka korzystającego z treści internetowych, np. oprogramowania antywirusowego, programów ochrony rodzicielskiej, aplikacji

${ }^{1}$ Bardziej ogólne - dotyczące nie tylko internetu - pojęcie mediacji rodzicielskiej wywodzi się z tradycji badania wpływu mediów masowych na odbiorców, szczególnie najmłodszych. Opisuje ono ochronną rolę rodziców pełniących rolę buforu osłabiającego negatywne oddziaływanie mediów (głównie telewizji) na poznawczy, emocjonalny i społeczny rozwój dzieci i młodzieży. 
ograniczających czas korzystania z dostępu do internetu (por. np. Kirwil i in., 2009; Livingstone i Helsper, 2008; Livingstone i in., 2017).

W tym rozdziale prezentujemy wyniki dotyczące praktyk wychowawczych stosowanych przez rodziców w celu minimalizowania zagrożeń i maksymalizowania korzyści płynących z korzystania z internetu. Omówimy również zebrane w badaniu dane na temat postaw dzieci i nastolatków wobec rodzicielskiego wsparcia i ochrony. Dodatkowo przedstawimy wyniki dotyczące tzw. zjawiska „sharentingu" (od ang. share - dzielić się, rozpowszechniać oraz parenting - rodzicielstwo), czyli takich działań rodziców, których konsekwencją może być narażenie dziecka na dodatkowe ryzyko w sieci. Prezentowane analizy opierają się na odpowiedziach udzielonych przez młodych respondentów. Wyniki badania ich rodziców, którym zadaliśmy analogiczne pytania o stosowane metody ochrony i wsparcia, opublikujemy w osobnym raporcie (w przygotowaniu).

\section{Jakie strategie wychowawcze dotyczące korzystania z internetu stosują rodzice?}

W drugiej fali badania EU Kids Online w Polsce zapytaliśmy o trzy główne strategie wychowawcze stosowane przez rodziców w celu zwiększania korzyści i minimalizowania ryzyka dla dziecka korzystającego z technologii sieciowych, tj. wsparcie aktywne, stosowanie restrykcji oraz korzystanie z rozwiązań technologicznych. Rozkład odpowiedzi udzielonych przez dzieci i młodzież ${ }^{2}$ oraz wyniki, z uwzględnieniem różnic wiekowych i związanych z płcią (dziecka), prezentujemy poniżej.

\section{Aktywne wsparcie}

Skala tzw. strategii aktywnych zawiera 11 pozycji opisujących praktyki wychowawcze, mające na celu wspieranie dziecka korzystającego z internetu poprzez rozwijanie jego kompetencji cyfrowych oraz umiejętności radzenia sobie z zagrożeniami w sieci.

2 Zestawienie odpowiedzi udzielonych przez rodziców i dzieci na analogiczne pytania z zakresu stosowania różnych strategii wychowawczych przez rodziców publikujemy w osobnym raporcie (w przygotowaniu). 
Tabela 5.1. Aktywne wsparcie (Kiedy korzystasz z internetu, jak często któreś z Twoich rodziców albo opiekunów robi którekolwiek z wymienionych rzeczy?)

\begin{tabular}{|c|c|c|c|c|c|c|}
\hline Działania wychowawcze rodzica/opiekuna & $\begin{array}{l}\text { Nie wiem / Trud- } \\
\text { no powiedzieć } \\
\%\end{array}$ & $\begin{array}{l}\text { Nigdy } \\
\%\end{array}$ & $\begin{array}{l}\text { Prawie } \\
\text { nigdy } \\
\%\end{array}$ & $\begin{array}{l}\text { Czasem } \\
\%\end{array}$ & $\begin{array}{c}\text { Często } \\
\%\end{array}$ & $\begin{array}{l}\text { Bardzo } \\
\text { często } \\
\%\end{array}$ \\
\hline Radzi, jak bezpiecznie korzystać z internetu & 10,2 & 21,3 & 20,1 & 22,4 & 9,3 & 16,7 \\
\hline $\begin{array}{l}\text { Pomaga mi, kiedy w internecie coś jest trudno } \\
\text { zrobić albo znaleźć }\end{array}$ & 10,5 & 26,7 & 16,0 & 21,6 & 8,7 & 16,5 \\
\hline $\begin{array}{l}\text { Pomaga mi, kiedy coś mnie zaniepokoi albo } \\
\text { zdenerwuje w internecie }\end{array}$ & 10,9 & 26,3 & 17,9 & 20,6 & 7,8 & 16,3 \\
\hline $\begin{array}{l}\text { Rozmawia ze mną o tym, że niektóre rzeczy, } \\
\text { które napotykam albo robię w internecie, są } \\
\text { płatne (np. kiedy ktoś próbuje mi coś sprzedać) }\end{array}$ & 11,6 & 31,7 & 15,4 & 17,6 & 8,2 & 15,5 \\
\hline Rozmawia ze mną o tym, co robię w internecie & 9,4 & 26,0 & 23,8 & 21,9 & 9,1 & 9,8 \\
\hline $\begin{array}{l}\text { Wyjaśnia, dlaczego niektóre strony } \\
\text { internetowe są dobre albo złe }\end{array}$ & 11,0 & 30,3 & 19,0 & 17,5 & 9,2 & 13,0 \\
\hline $\begin{array}{l}\text { Zachęca mnie do samodzielnego poszukiwania } \\
\text { i uczenia się różnych rzeczy w internecie }\end{array}$ & 10,3 & 28,6 & 21,5 & 22,3 & 8,8 & 8,6 \\
\hline $\begin{array}{l}\text { Rozmawia ze mną o tym, co mogę zrobić, gdyby } \\
\text { coś w internecie kiedykolwiek mnie zaniepoko- } \\
\text { iło albo zdenerwowało }\end{array}$ & 10,8 & 32,2 & 22,1 & 18,1 & 6,5 & 10,3 \\
\hline Robi coś razem ze mną w internecie & 9,0 & 32,8 & 26,9 & 19,3 & 6,6 & 5,4 \\
\hline Jest w pobliżu, kiedy korzystam z internetu & 9,5 & 33,9 & 26,4 & 17,4 & 6,2 & 6,5 \\
\hline Siedzi przy mnie, kiedy korzystam z internetu & 8,0 & 48,6 & 26,9 & 7,8 & 5,4 & 3,3 \\
\hline
\end{tabular}

Cała próba ${ }^{3}$ z wyłączeniem braków i odpowiedzi „Wolę nie odpowiadać” (od 13\% do 14,3\%)

Do najczęściej stosowanych metod aktywnego wsparcia, po które rodzice badanych sięgają przynajmniej czasem, należą porady dotyczące bezpiecznego korzystania z internetu. Dostaje je prawie połowa (48,3\%) ankietowanych uczniów. Podobnie często rodzice pomagają dzieciom, kiedy tym trudno jest coś zrobić czy znaleźć $(46,8 \%)$ lub też kiedy coś je zaniepokoi albo zdenerwuje

${ }^{3}$ Cała próba obejmuje dzieci i młodzież w wieku od 9 do 17 lat, $N=1249$ z zastrzeżeniem, że dokładna liczebność bazowa dla konkretnych pytań różni się od wyjściowej ze względu na braki odpowiedzi. W opisach każdorazowo podano przedziały procentowe braków dla danego zestawu pytań, z uwzględnieniem odpowiedzi niediagnostycznych, np. „Wolę nie odpowiadać”. 
$(44,8 \%)$ w internecie. Co ciekawe, najrzadziej - według dzieci - rodzice stosują tzw. metody bierne, czyli pozostawanie obok lub w pobliżu dziecka, gdy korzysta ono z internetu. Ten rodzaj aktywności był najczęściej stosowany przez rodziców w Polsce w roku 2010 (Kirwil, 2011). Wydaje się, że spadek popularności tej metody ochrony wiąże się przede wszystkim ze zmianą sposobu, w jaki dzieci i młodzież korzystają obecnie z internetu. Jak wynika z naszych badań (patrz rozdział 2), młodzi logują się do sieci głównie poprzez urządzenia mobilne w wielu przypadkach poza domem i poza zasięgiem wzroku rodziców.

\section{Ważny fakt}

Upowszechnienie mobilnego dostępu do internetu sprawiło, iż najbardziej niegdyś popularna metoda wychowawcza stosowana przez polskich rodziców - ochrona bierna, tj. przebywanie w pobliżu dziecka, gdy korzysta ono z internetu (ok. 94\% wskazań w 2010) - spadła na jedno z ostatnich miejsc w rankingu najczęściej $(30,1 \%)$ wskazywanych przez dziecko taktyk wsparcia.

\section{Stosowanie zakazów i ograniczeń}

Skala strategii restrykcyjnych opisuje 10 różnego rodzaju ograniczeń i zakazów stosowanych przez rodziców i opiekunów w celu zapewnienia bezpieczeństwa dziecku korzystającemu z internetu.

Tabela 5.2. Ochrona restrykcyjna (Które z wymienionych rzeczy rodzice lub opiekunowie pozwalają Ci robić w internecie? Odpowiedz, czy musisz pytać o zgodę, żeby robić rzeczy wymienione poniżej?)

\begin{tabular}{|c|c|c|c|c|}
\hline $\begin{array}{c}\text { Aktywności dzieci online } \\
\text { regulowane przez rodziców/ } \\
\text { opiekunów }\end{array}$ & $\begin{array}{c}\text { Nie wiem, czy } \\
\text { wolno mi to robić, } \\
\text { czy nie wolno } \\
\%\end{array}$ & $\begin{array}{c}\text { Mogę to robić } \\
\text { zawsze } \\
\text { kiedy chce } \\
\%\end{array}$ & $\begin{array}{c}\text { Mogę to robić, tyl- } \\
\text { ko kiedy dostanę } \\
\text { zgodę albo } \\
\text { pod opieką } \\
\%\end{array}$ & $\begin{array}{c}\text { Nie wolno mi } \\
\text { tego robić } \\
\%\end{array}$ \\
\hline $\begin{array}{l}\text { Wymienianie się z innymi } \\
\text { w internecie zdjęciami, filmami } \\
\text { lub muzyką }\end{array}$ & 6,4 & 58,6 & 19,6 & 15,4 \\
\hline
\end{tabular}




\begin{tabular}{|c|c|c|c|c|}
\hline $\begin{array}{l}\text { Używanie kamery interneto- } \\
\text { wej albo w telefonie komór- } \\
\text { kowym (np. kiedy rozmawiam } \\
\text { przez Skype'a) }\end{array}$ & 8,5 & 61,0 & 19,0 & 11,4 \\
\hline $\begin{array}{l}\text { Spędzanie czasu } \\
\text { w wirtualnym świecie } \\
\text { (np. grać w Minecraft) }\end{array}$ & 4,7 & 67,1 & 19,4 & 8,8 \\
\hline Pobieranie muzyki albo filmy & 4,8 & 68,3 & 19,0 & 8,0 \\
\hline $\begin{array}{l}\text { Granie w gry internetowe } \\
\text { z innymi }\end{array}$ & 3,2 & 71,7 & 18,7 & 6,4 \\
\hline $\begin{array}{l}\text { Korzystanie z portalu spo- } \\
\text { łecznościowego albo aplikacji } \\
\text { (np. z Facebooka, Snapchatu, } \\
\text { Instagramu) }\end{array}$ & 3,9 & 71,3 & 16,0 & 8,9 \\
\hline $\begin{array}{l}\text { Korzystać z internetu, żeby od- } \\
\text { rabiać lekcje albo w sprawach } \\
\text { związanych ze szkołą }\end{array}$ & 2,9 & 75,4 & 14,5 & 7,1 \\
\hline $\begin{array}{l}\text { Czytanie albo oglądanie wia- } \\
\text { domości w internecie }\end{array}$ & 2,7 & 76,7 & 15,3 & 5,2 \\
\hline $\begin{array}{l}\text { Oglądanie filmików video } \\
\text { (np. na YouTubie) }\end{array}$ & 1,2 & 82,2 & 13,9 & 2,7 \\
\hline
\end{tabular}

Jeśli chodzi o ochronę przez restrykcje, dzieci najczęściej wskazują ograniczenia dotyczące wymiany plików online $(35,0 \%)$ oraz korzystania z urządzeń rejestrujących, takich jak kamera sieciowa lub w telefonie komórkowym $(30,4 \%)$. Do katalogu metod restrykcyjnych należy również ustalanie zasad określających, kiedy i jak długo dziecko czy nastolatek może korzystać z internetu (patrz tabela $\left.5.3^{4}\right)$. Jest to druga najczęściej wskazywana $(32,9 \%)$ metoda ochrony przez ograniczanie dostępu do internetu.

Jak wynika z naszych analiz aktywnością najrzadziej ograniczaną przez rodziców jest oglądanie filmików video (np. na kanałach YouTube). Jakiekolwiek ograniczenia w tym zakresie odczuwa zaledwie 16,6\% dzieci. Częściej rodzice

${ }^{4}$ Ze względu na format odpowiedzi pytanie to włączyliśmy do wykresu 5.3, ilustrującego wyniki w zakresie wykorzystania rozwiązań technologicznych do wsparcia i ochrony młodych internautów. 
regulują aktywności nawet dużo bardziej, zdawałoby się, korzystne dla dziecka, tj. używanie internetu w celu odrabiania lekcji i w sprawach związanych ze szkołą (20,6\%) albo do czytania i oglądania wiadomości (21,6\%).

\section{Korzystanie z rozwiązań technologicznych}

Ostatnia z analizowanych skal zawiera 8 pytań dotyczących stosowania przez rodziców i opiekunów różnego rodzaju urządzeń, oprogramowania oraz ustawień w aplikacjach online, służących zwiększaniu bezpieczeństwa dziecka.

Tabela 5.3. Stosowanie technologii do zapewniania bezpieczeństwa dzieciom (Czy któreś z Twoich rodziców albo opiekunów robi jakieś z następujących rzeczy?)

\begin{tabular}{|c|c|c|c|}
\hline $\begin{array}{l}\text { Wykorzystanie przez rodzica/opiekuna rozwiązań technolo- } \\
\text { gicznych zwiększających bezpieczeństwo dziecka online }\end{array}$ & $\begin{array}{c}\text { Nie wiem / } \\
\text { Trudno } \\
\text { powiedzieć } \\
\%\end{array}$ & $\begin{array}{c}\mathrm{Nie} \\
\%\end{array}$ & $\begin{array}{c}\text { Tak } \\
\%\end{array}$ \\
\hline [Ustala zasady, kiedy i jak długo mogę korzystać z internetu] ${ }^{a}$ & 19,2 & 47,9 & 32,9 \\
\hline Korzysta z programów blokujących reklamy & 19,4 & 61,4 & 19,1 \\
\hline $\begin{array}{l}\text { Korzysta z urządzeń, które pozwalają sprawdzić, gdzie je- } \\
\text { stem (np. GPS albo usługa w telefonie) }\end{array}$ & 21,2 & 66,0 & 12,8 \\
\hline $\begin{array}{l}\text { Korzysta z programu kontroli rodzicielskiej albo innego spo- } \\
\text { sobu blokowania lub filtrowania stron internetowych }\end{array}$ & 20,7 & 66,5 & 12,7 \\
\hline $\begin{array}{l}\text { Korzysta z ustawień rodzicielskich (np. w komputerze albo } \\
\text { w usłudze dostępu do internetu), które pozwalają pobierać } \\
\text { tylko niektóre aplikacje (nie wszystkie) }\end{array}$ & 21,0 & 66,5 & 12,4 \\
\hline $\begin{array}{l}\text { Korzysta z takiej usługi dostępu do internetu, w której moż- } \\
\text { na ograniczyć czas, kiedy używam internetu }\end{array}$ & 20,4 & 67,5 & 12,1 \\
\hline $\begin{array}{l}\text { Korzysta z ustawień rodzicielskich (np. w komputerze albo } \\
\text { w usłudze dostępu do internetu), które wysyłają powiadomie- } \\
\text { nie, jeśli chcę coś kupić w internecie albo w aplikacji }\end{array}$ & 22,3 & 66,2 & 11,5 \\
\hline $\begin{array}{l}\text { Korzysta z programów, które ograniczają to, z kim mogę kon- } \\
\text { taktować się przez wiadomości tekstowe albo głosowe }\end{array}$ & 21,9 & 67,2 & 10,9 \\
\hline $\begin{array}{l}\text { Korzysta z programu kontroli rodzicielskiej albo innego spo- } \\
\text { sobu śledzenia, które strony internetowe odwiedzam }\end{array}$ & 21,8 & 68,4 & 9,8 \\
\hline
\end{tabular}

Cała próba, z wyłączeniem braków i odpowiedzi „Wolę nie odpowiadać” (od 15,9\% do 17,0\%); ato pozycja dotycząca stosowania zasad odnoszących się do korzystania z internetu - należy treściowo do skali metod restrykcyjnych (tabela 5.2) i jest omawiana wraz $z$ nimi 
Podobnie jak we wcześniejszych badaniach (Kirwil, 2011), odpowiedzi dzieci wskazują na niski poziom wykorzystania przez rodziców rozwiązań technologicznych w celu ochrony przed zagrożeniami w internecie. Jest to nadal zaledwie kilkanaście procent - od 19,1\% w przypadku oprogramowania blokującego reklamy, przez około 13\% korzystających z aplikacji pozwalających zlokalizować miejsce pobytu dziecka (lub jego urządzenia mobilnego) i od 12,7\% do 9,8\% w przypadku innych programów do kontroli rodzicielskiej. Nieco wyższe wartości uzyskujemy, jeśli przeanalizujemy wyniki mówiące o tym, czy rodzice lub opiekunowie stosują przynajmniej jedną (lub więcej) taktyk wsparcia i ochrony spośród tych, o które pytaliśmy młodych respondentów (patrz wykres 5.1).

Warto jeszcze w tym miejscu wskazać na stosunkowo wysoki odsetek dzieci, które nie mają wiedzy na temat stosowania przez rodziców metod ochrony z tej kategorii. Średnio co piąte dziecko (od 19,4\% do 22,3\%) nie wie, czy jego rodzic korzysta z oprogramowania typu ochrona rodzicielska. Nie jest przy tym jasne, czy wynika to stąd, że rodzice świadomie nie ujawniają dziecku informacji o korzystaniu z programów ochronnych (np. w obawie przed wyłączeniem przez nie takich ograniczeń), czy raczej w ogóle temat ten nie jest poruszany w rozmowach, ponieważ sami rodzice nie mają wystarczającej wiedzy i/lub kompetencji, aby z oprogramowania korzystać. W świetle ogólnie niskich wyników pod względem wykorzystania przez polskich rodziców oprogramowania do ochrony dzieci korzystających z internetu to drugie wyjaśnienie wydaje się bardziej prawdopodobne.

Podsumowanie informacji na temat stosowanych przez rodziców metod wspierania i ochrony dziecka korzystającego z internetu prezentujemy na wykresie 5.1.

Łatwo zauważyć, że polscy rodzice - niezależnie od wieku i płci swoich dzieci - najchętniej sięgają po aktywne metody wsparcia. Najrzadziej rodzice wspierają się rozwiązaniami technologicznymi w celu zapewnienia bezpieczeństwa dziecku korzystającemu z internetu, aczkolwiek odsetek rodziców, sięgających po tę metodę, zwiększył się znacząco względem roku 2010 - z około 17 do prawie 44 procent. Bardzo wyraźna jest też rezygnacja rodziców z metod restrykcyjnych wraz z wiekiem dziecka. W grupie rodziców 9-10-latków z tej taktyki korzysta niemal dziewięciu na dziesięciu rodziców, natomiast w odniesieniu do nastolatków po zakazy i nakazy sięga (wg relacji samych dzieci) już tylko co czwarty rodzic. 
Wykres 5.1. Wzorce mediacji rodzicielskiej - odsetek dzieci wskazujących, że ich rodzice (opiekunowie) stosują jedną lub więcej spośród danego rodzaju metod wsparcia i ochrony (rozkład \%)
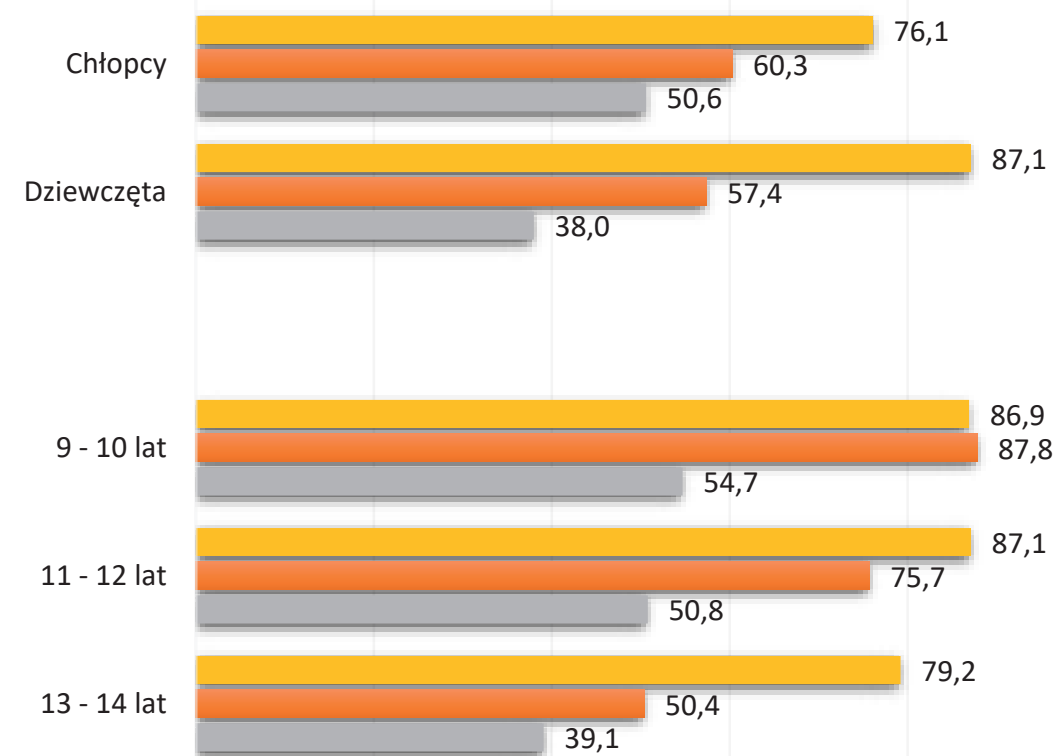

$15-17$ lat

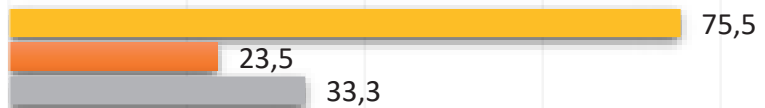

Wszyscy - 2010

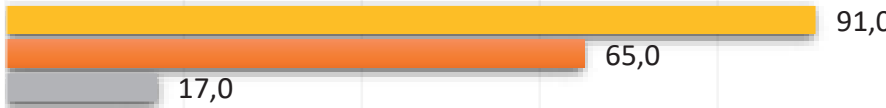

91,0

17,0

Wszyscy - 2018

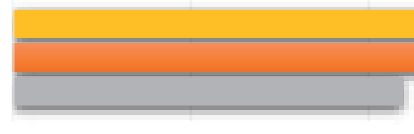

43,9

$0 \%$

$\begin{array}{llll}20 \% & 40 \% & 60 \% & 80 \% \\ \text { Aktywne } & \text { Restrykcyjne } & \text { - Techniczne }\end{array}$

82,1

$100 \%$

Cała próba, z wyłączeniem braków i odpowiedzi „Nie wiem/Trudno powiedzieć” oraz „Wolę nie odpowiadać” (od $16,8 \%$ do $25,1 \%$ )

Jeśli chodzi o różnice między chłopcami a dziewczynkami, te ostatnie rzadziej wskazują, że ich rodzice korzystają z technologicznych narzędzi ochrony (38\% vs. $50,6 \% ; p<0,001$ ), ale częściej deklarują, że rodzice wspierają je metodami aktywnymi ( $87,1 \%$ vs. $76,1 \%$; $p<0,001)$. 


\section{Jaki jest stosunek dzieci do działań rodziców?}

To, czy oddziaływania wychowawcze rodziców odniosą zamierzony skutek, zależy - przynajmniej w pewnym stopniu - od samych dzieci. Jak wiadomo, wszelkiego rodzaju zakazy, ograniczenia i kontrola stosowane przez rodziców - także te dotyczące korzystania z internetu - mogą budzić niechęć, szczególnie u dorastającej młodzieży. $Z$ drugiej strony, na co wskazują wyniki badań (Livingstone i in., 2017), może być też tak, że dzieci doświadczające lub obawiające się zagrożeń w sieci aktywnie zgłaszają się po wsparcie i ochronę do swoich rodziców czy opiekunów. Zapytaliśmy więc młodych respondentów, jakiego wsparcia ze strony rodziców poszukują (proaktywnie), a także jak oceniają wsparcie, które dostają i czy z niego rzeczywiście korzystają.

Tabela 5.4. Aktywne poszukiwanie wsparcia (Czy kiedykolwiek robiłeś/aś któreś z wymienionych rzeczy?)

\begin{tabular}{|c|c|c|c|c|c|}
\hline $\begin{array}{l}\text { Działania dzieci związane } \\
\text { z poszukiwaniem wsparcia }\end{array}$ & $\begin{array}{l}\text { Nigdy } \\
\%\end{array}$ & $\begin{array}{l}\text { Prawie } \\
\text { nigdy } \\
\%\end{array}$ & $\begin{array}{c}\text { Czasem } \\
\%\end{array}$ & $\begin{array}{c}\text { Często } \\
\%\end{array}$ & $\begin{array}{l}\text { Bardzo } \\
\text { często } \\
\%\end{array}$ \\
\hline $\begin{array}{l}\text { Powiedziałem/am rodzicom albo opieku- } \\
\text { nom o rzeczach, które mnie zaniepokoiły } \\
\text { albo zdenerwowały w internecie }\end{array}$ & 28,6 & 24,8 & 21,7 & 12,7 & 12,2 \\
\hline $\begin{array}{l}\text { Poprosiłem/am rodziców albo opiekunów } \\
\text { o pomoc w sytuacji, z którą nie mogłem/am } \\
\text { sobie poradzić w internecie }\end{array}$ & 42,1 & 22,0 & 20,0 & 5,8 & 10,0 \\
\hline $\begin{array}{l}\text { Sam/a zacząłem/am rozmowę z którymś } \\
\text { z rodziców albo opiekunów, na temat tego, } \\
\text { co robię w internecie }\end{array}$ & 37,2 & 28,9 & 18,3 & 10,0 & 5,7 \\
\hline $\begin{array}{l}\text { Pytałem/am rodziców albo opiekunów } \\
\text { o radę, jak zachować się w internecie }\end{array}$ & 44,3 & 26,0 & 15,9 & 6,4 & 7,4 \\
\hline
\end{tabular}

Cała próba, z wyłączeniem braków i odpowiedzi „Nie wiem/Trudno powiedzieć" oraz "Wolę nie odpowiadać” (od $23,0 \%$ do $24,1 \%$ )

Prawie połowa $(46,6 \%)$ młodych użytkowników internetu decyduje się opowiedzieć rodzicom o tym, co w sieci budzi ich niepokój albo zdenerwowanie. Mniej więcej co trzeci młody internauta sam inicjuje rozmowy na temat tego, co robi w sieci albo prosi rodziców o pomoc, gdy z czymś sobie nie radzi online. Niespełna jedna trzecia $(29,7 \%)$ radzi się rodziców lub opiekunów, jak należy zachować się w internecie. 
Aby przyjrzeć się dokładniej temu, na ile chętnie dzieci i nastolatki sięgają po opinię i pomoc rodziców, przeanalizowaliśmy różnice w deklaracjach badanych ze względu na ich wiek i płeć (wykres 5.2).

Wykres 5.2. Aktywne poszukiwanie wsparcia - wg płci i wieku

Chłopcy

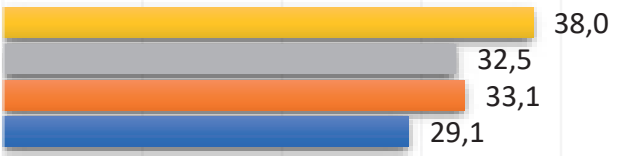

Dziewczęta

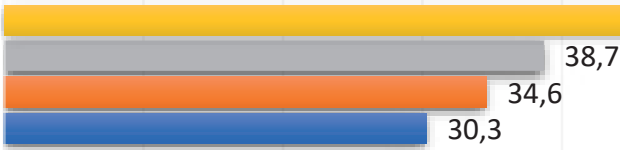

53,7

30,3

9 - 10 lat

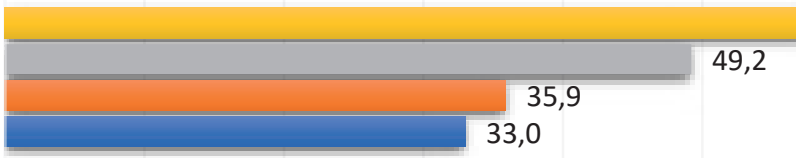

57,9

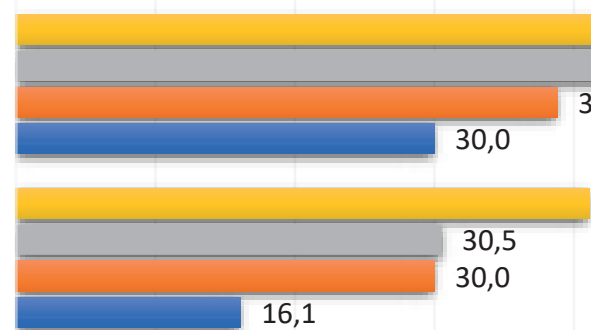

42,9

56,8

$11-12$ lat 38,8

$13-14$ lat

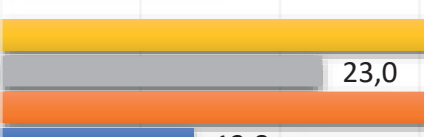

32,1

15 - 17 lat 13,8

31,2

\section{1,1}

Wszyscy

$0 \%$

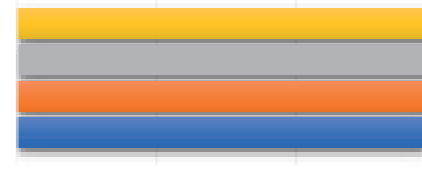

$10 \% \quad 20 \% \quad 30 \%$

\section{5,9}

33,9

29,7

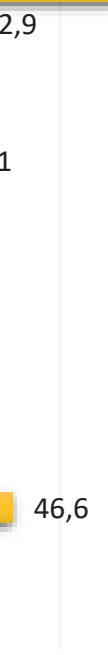

- Powiedziałem/am rodzicom albo opiekunom o rzeczach, które mnie zaniepokoiły albo zdenerwowały w internecie

Poprosiłem/am rodziców albo opiekunów o pomoc w sytuacji, z którą nie mogłem/am sobie poradzić $w$ internecie

Sam/a zacząłam/em rozmowę z którymś z rodziców albo opiekunów, na temat tego, co robię $w$ internecie

- Pytałem/am rodziców albo opiekunów o radę, jak zachować się w internecie 
Okazuje się, że dziewczęta częściej niż chłopcy zgłaszają, że coś je zaniepokoiło lub zdenerwowało w sieci $(p<0,001)$ i proszą o pomoc w sytuacjach, gdy same nie mogą poradzić sobie w internecie $(p=0,045)$. Natomiast, jak można się spodziewać, wraz z wiekiem maleje tendencja do poszukiwania u rodziców niemal każdego z wymienionych rodzajów wsparcia $(p<0,001)$, z wyjątkiem inicjowania rozmowy na temat aktywności w internecie $(p=0,13)$. Wynika to zapewne po części z faktu, iż z wiekiem dorastające dzieci coraz częściej starają się radzić sobie we własnym zakresie lub szukać wsparcia u rówieśników. Dodatkowo, z wiekiem rosną też kompetencje w zakresie korzystania z internetu choćby z racji coraz większego stażu. Warto jednak zauważyć, że niezależnie od wieku - czyli nawet wśród najstarszych nastolatków - około jedna trzecia aktywnie szuka kontaktu z rodzicami, aby porozmawiać o swoich doświadczeniach online.

\section{Ważny fakt}

Niemal co drugie badane dziecko opowiada rodzicom o tym, co je niepokoi i denerwuje w sieci. Odsetki są istotnie większe w przypadku dziewczynek $(53,7 \%)$ i młodszych dzieci (9-10 lat oraz 11-12 lat - odpowiednio: 57,9\% i 56,8\%). Najmniej chętnie młodzi radzą się w kwestii właściwego zachowania w sieci. Ogólnie, im dzieci starsze tym rzadziej zwracają się po pomoc. Mimo to, znacząca część starszych nastolatków (33,9\% w grupie 15-17 lat) nadal proaktywnie poszukuje kontaktu z rodzicami, aby porozmawiać o tym, co robią w internecie.

W następnej kolejności zapytaliśmy dzieci i młodzież, czy wsparcie i ochrona, jakie otrzymują od swoich rodziców lub opiekunów, na ogół pomagają w tym, aby korzystanie z internetu było pozytywnym doświadczeniem.

Podobnie jak w poprzedniej fali badań, spora część dzieci $(73,8 \%)$ pozytywnie ocenia starania rodziców - jako trochę lub bardzo pomocne. Szczególnie wysoko oceniają wsparcie rodziców młodsi (9-12 lat), jednak około 18\% z tej grupy nie postrzega działań rodziców jako wystarczająco skutecznych. Warto też zauważyć, że chłopcy nieco częściej niż dziewczęta oceniają wysiłki rodziców jako mało pomocne (30,4\% vs. $22,1 \%$; $p=0,03)$. 
Wykres 5.3. Rozkład procentowy odpowiedzi na pytanie: Czy rzeczy, które robią Twoi rodzice (opiekunowie) w związku z tym, jak korzystasz z internetu, pomagają w tym, żeby lepiej korzystało Ci się z internetu, czy niezbyt pomagają?

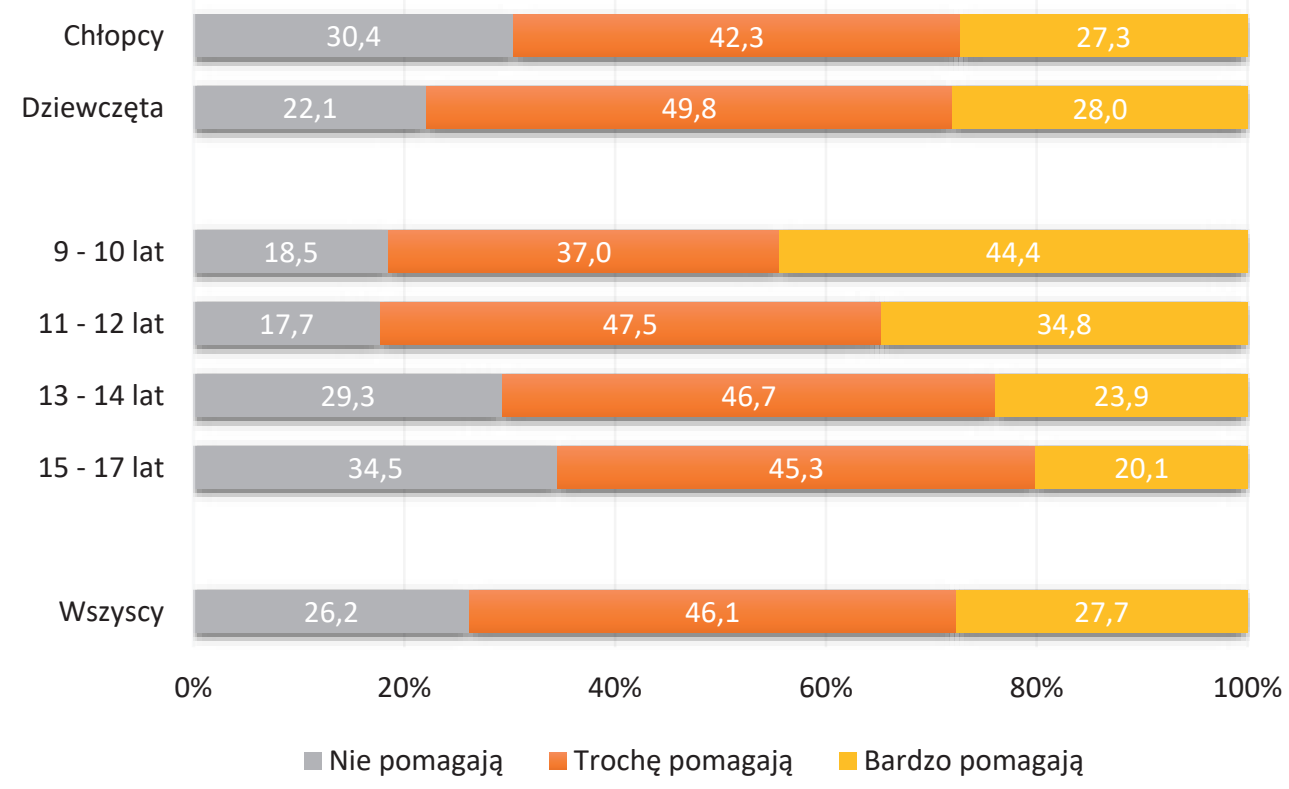

Cała próba, z wyłączeniem braków (24,7\%) i odpowiedzi „Nie wiem/Trudno powiedzieć” $(23,9 \%)$ oraz „Wolę nie odpowiadać" $(10,7 \%)$

Aby zweryfikować możliwe powody niezadowolenia dzieci ze wsparcia i ochrony rodzicielskiej, zadaliśmy pytanie o to, czy działania rodziców odbierają jako ograniczające ich aktywność w internecie.

Z rozkładu odpowiedzi wyraźnie wynika, że im młodsze dziecko, tym bardziej czuje się ograniczane w swoim korzystaniu z internetu $(p<0,001)$. Wyniki analiz nie zaskakują, biorąc pod uwage zmniejszające się z wiekiem natężenie ochrony rodzicielskiej. Z drugiej jednak strony, można też było spodziewać się odwrotnej tendencji, a mianowicie, że to nastolatki mogłyby czuć się bardziej ograniczone działaniami rodziców niż młodsze dzieci. Niezależnie od wieku, poczucie ograniczenia swobody może prowadzić do reakcji dziecka odwrotnych od oczekiwanych i prowokować je do lekceważenia rad i poleceń rodzica lub opiekuna. Zapytaliśmy respondentów, czy zdarza im się lekceważyć to, co o korzystaniu z internetu mówią im rodzice. 
Wykres 5.4. Rozkład procentowy odpowiedzi na pytanie: Czy rzeczy, które robią Twoi rodzice w związku z tym, jak korzystasz z internetu, ograniczają Cię w tym, co możesz robić w internecie czy niezbyt ograniczają?

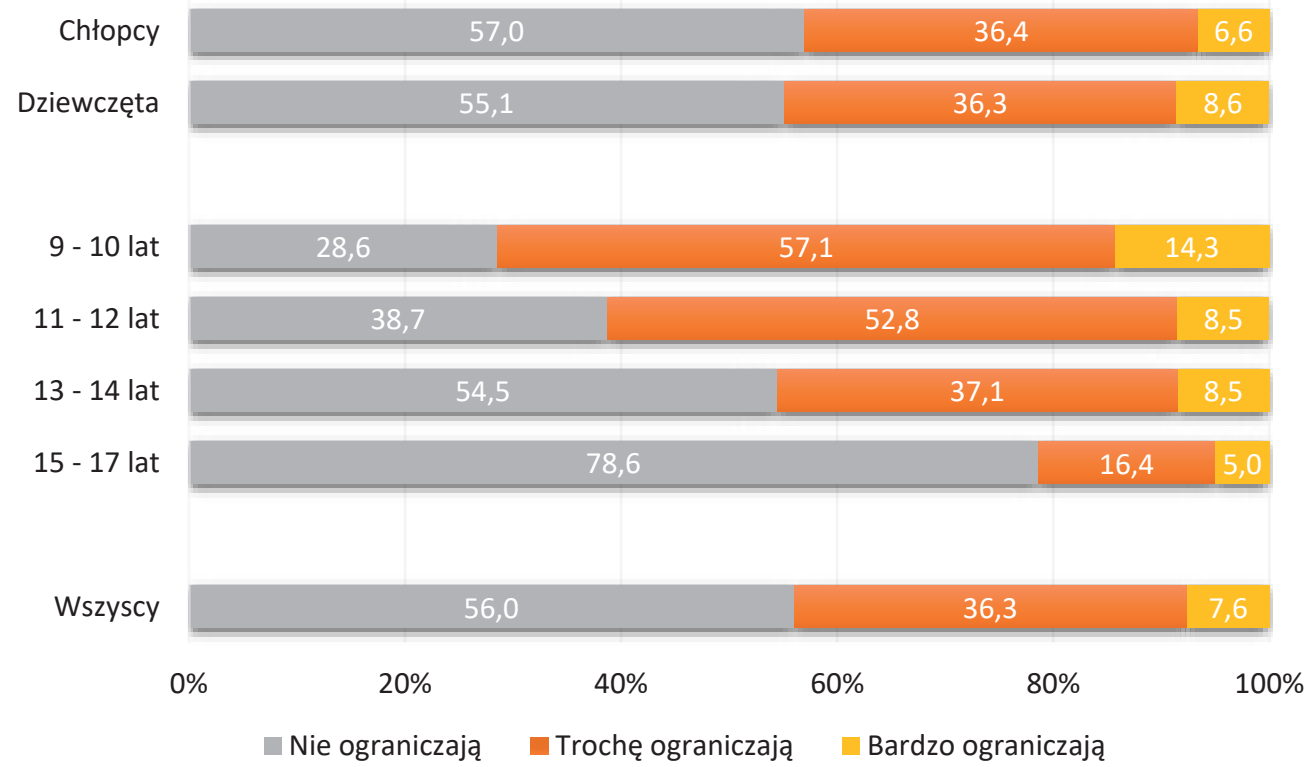

Cała próba, z wyłączeniem braków (24,7\%) i odpowiedzi „Nie wiem/Trudno powiedzieć” (15,1\%) oraz „Wolę nie odpowiadać” (10,8\%)

Wykres 5.5. Rozkład procentowy odpowiedzi na pytanie: A czy Ty kiedykolwiek lekceważysz to, co o korzystaniu z internetu mówi(ą) Ci rodzic(e)?

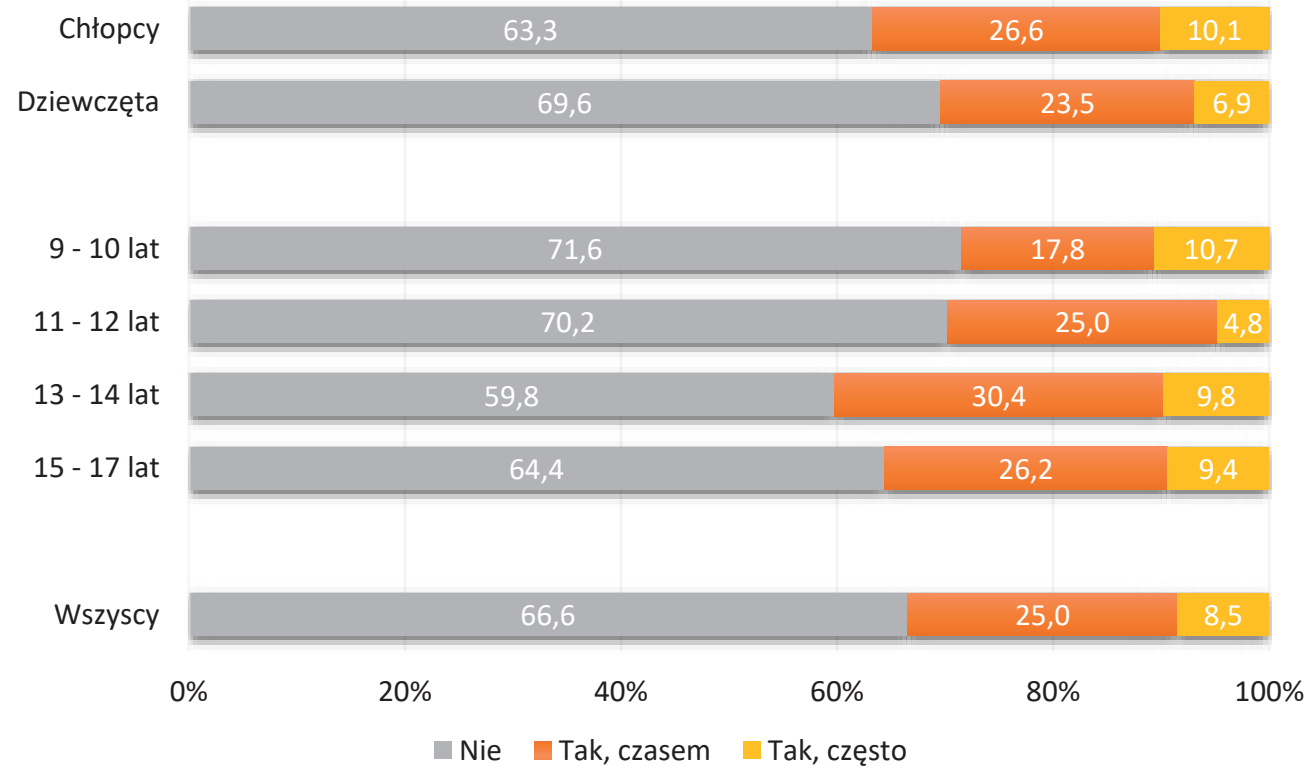

Cała próba, z wyłączeniem braków (3,3\%) i odpowiedzi „Nie wiem/Trudno powiedzieć” (16,6\%) oraz „Wolę nie odpowiadać” (11,1\%)

\section{6}


Uzyskane wyniki wskazują, że aż dwie trzecie dzieci w wieku 9-17 lat deklaruje, iż nie lekceważy rad i zaleceń rodziców. Jednak co czwarty pytany przyznaje, że czasem ignoruje wysiłki rodziców, a kolejne 8,5\% robi to często. Jak można się spodziewać, nieco częściej do lekceważenia wymagań rodziców i opiekunów przyznają się chłopcy (36,7 vs. 30,4\%; różnica istotna jedynie na poziomie tzw. tendencji statystycznej - $p=0,051)$ i dzieci starsze (29,8\% dla 9-10-latków i do 28,5\% dla 11-12-latków vs.40,2\% dla 13-14-latków i dla 35,6\% 15-17-latków; $p=0,04)$.

Na koniec zapytaliśmy, czy wielkość wsparcia oferowanego przez rodziców odpowiada oczekiwaniom dzieci.

Wykres 5.6. Rozkład procentowy odpowiedzi na pytanie: Ogólnie rzecz biorąc, czy chciałbyś/łabyś, żeby Twoi rodzice interesowali się tym, co robisz w internecie tyle samo, co teraz, czy może bardziej albo mniej?

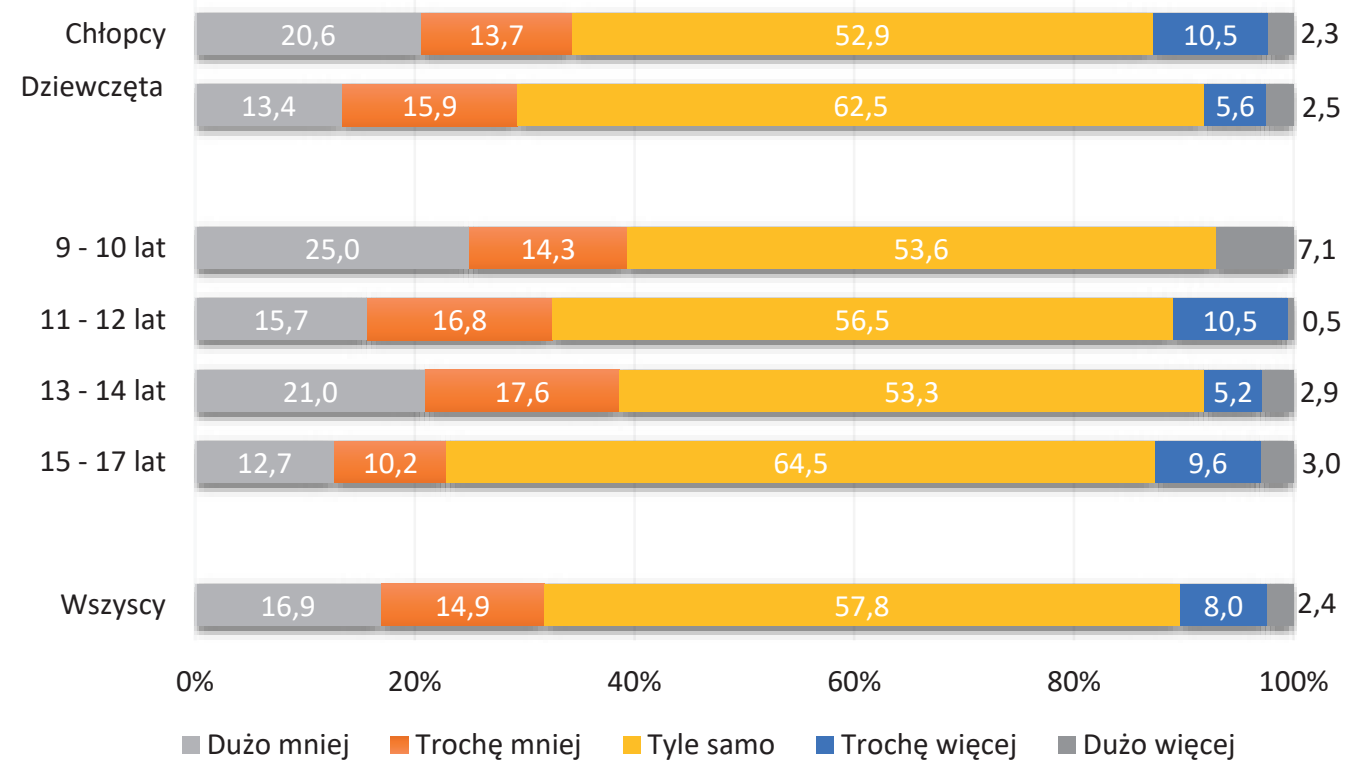

Cała próba z wyłączeniem braków (22,7\%) i odpowiedzi „Nie wiem/Trudno powiedzieć” (17,8\%) oraz „Wolę nie odpowiadać" (9,3\%)

Jak wynika z analiz, więcej niż połowa ankietowanych - szczególnie młodzież (chłopcy i dziewczęta łącznie) w wieku 15-17 lat oraz dziewczęta - uważa, że ilość wsparcia i ochrony rodzicielskiej jest odpowiednia. Co ciekawe, w porównaniu z dziewczętami więcej chłopców chciałoby, aby natężenie opieki rodziców 
uległo zmianie - albo było zdecydowanie mniejsze (20,6\% vs. 13,4\%) albo przeciwnie - trochę większe (10,5\% vs. 5,6\%; $p=0,03$ dla porównań łącznie). Pod względem różnic wiekowych ciekawy jest wynik wskazujący na to, iż w grupie najstarszej (15-17 lat) co dziesiąty młody człowiek oczekuje ze strony swoich rodziców i opiekunów większego zainteresowania jego aktywnością w internecie. Wydaje się, że jest to ten moment rozwojowy, w którym coraz więcej wspólnych tematów może łączyć korzystających z sieci nastolatków, młodych dorosłych i ich rodziców.

\section{Ważny fakt}

Wyniki drugiej fali badań EU Kids Online - podobnie jak w pierwszej fali w 2010 roku wskazują na raczej pozytywny stosunek dzieci do działań podejmowanych przez rodziców w celu zwiększenia ich bezpieczeństwa w internecie. Warto podkreślić, że także starsza młodzież (a przynajmniej pewna jej część) zarówno oczekuje od rodziców, jak i sama inicjuje z nimi kontakt, aby podzielić się wrażeniami i doświadczeniami związanymi z korzystaniem z internetu.

\section{Sharenting - kiedy to rodzice są źródłem zagrożeń}

Jak dotąd analizowaliśmy tylko takie sytuacje, w których rola rodzica polega na ochronie i wsparciu dziecka korzystającego z internetu. Tymczasem, paradoksalnie, niektórzy rodzice, w sposób nie do końca uświadamiany, mogą stać się źródłem dodatkowego ryzyka dla swoich dzieci.

Sharenting, bo o nim mowa, to dość nowe zjawisko społeczne, polegające na tym, że rodzice - często bez wiedzy i zgody dzieci - umieszczają w sieci zdjęcia, filmy i inne treści na temat swoich pociech (Blum-Ross i Livingstone, 2017; Brosch, 2017). Choć zwykle intencje są dobre, to jednak dla dziecka takie nieprzemyślane i naruszające prawo do prywatności postępowanie rodzica może mieć bardzo przykre konsekwencje. W tegorocznej edycji badania EU Kids Online po raz pierwszy w ramach projektu zapytaliśmy młodych respondentów o doświadczenia związane z publikowaniem przez ich rodziców w internecie informacji o nich - np. wiadomości, zdjęć czy filmów. Cztery pytania dotyczące zjawiska sharentingu zadaliśmy jedynie starszym dzieciom i nastolatkom (11-17 lat). 
Wykres 5.7. Odsetki odpowiedzi na pytania dotyczące publikowania przez rodziców w internecie treści dotyczących ich dzieci (Jak często w OSTATNIM ROKU zdarzały Ci się w internecie wymienione sytuacje?)

Któreś z moich rodziców (opiekunów) umieściło w internecie informacje o mnie (np. słowa, obrazki, zdjęcia czy filmy) nie pytając, czy się na to zgadzam

Ktoś wysłał mi negatywne albo obraźliwe komentarze przez coś, co umieścili w internecie moi rodzice (opiekunowie)

Prosiłem moich rodziców (opiekunów) o usunięcie z internetu czegoś, co w nim umieścili

Byłem/am zdenerwowany/a przez coś, co umieścili w internecie moi rodzice (opiekunowie)

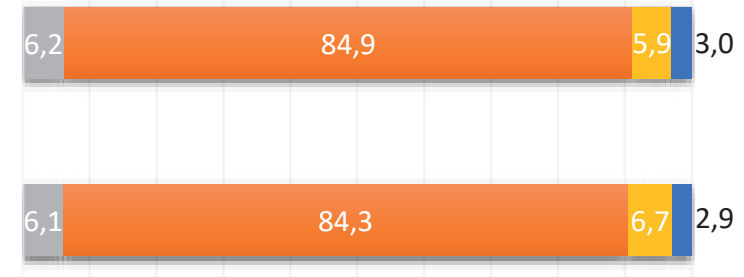

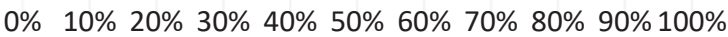

Nie wiem / Trudno powiedzieć $\quad$ Nigdy Kilka razy $\quad$ Raz w miesiącu lub częściej

Młodzież w wieku 11-17 lat, z wyłączeniem braków i odpowiedzi „Nie wiem/Trudno powiedzieć” oraz „Wolę nie odpowiadać" (od $33,1 \%$ do $33,5 \%$ )

Niemal co dziesiąty nastolatek (9,5\%) ma świadomość, że jego rodzice od czasu do czasu umieszczają w internecie jakieś treści na jego/jej temat bez pytania o zgodę. Podobny odsetek młodych respondentów deklaruje, że odczuwa zdenerwowanie w związku z tym, co na jego/jej temat publikują w sieci rodzice $(9,6 \%)$, oraz że proszą rodziców o usunięcie takich treści $(8,9 \%)$. Jakkolwiek zdecydowana większość pytanych nastolatków nie czuje się dotknięta problemem sharentingu, część młodych ludzi doświadcza związanych z tym zjawiskiem przykrości.

Aby dokładniej przyjrzeć się możliwym konsekwencjom nieodpowiedzialnego dzielenia się przez rodziców w internecie informacjami o dziecku, sprawdziliśmy jak rozkładają się odpowiedzi na pytania o doświadczanie negatywnych emocji i przykrych komentarzy wśród młodych internautów, których rodzice umieszczają (lub nie) treści na ich temat bez pytania o zgodę. 
Tabela 5.5. Odsetki nastolatków doświadczających negatywnych konsekwencji w związku z czymś, co umieścili w internecie rodzice (opiekunowie) - w zależności od tego, czy rodzic (opiekun) umieszczał w internecie informacje o swoim dziecku bez jego/jej zgody

Któreś z moich rodziców (opiekunów) umieściło w internecie informacje o mnie (np. słowa, obrazki, zdjęcia czy filmy), nie pytając, czy się na to zgadzam

\begin{tabular}{|c|c|c|c|}
\hline & & Nie \% & Tak \% \\
\hline \multirow{2}{*}{$\begin{array}{l}\text { Byłem/am zdenerwowany/a przez coś, } \\
\text { co umieścili w internecie moi rodzice } \\
\text { (opiekunowie) }^{A}\end{array}$} & $\mathrm{Nie}$ & 94,4 & 48,7 \\
\hline & Tak & 5,6 & 51,3 \\
\hline \multirow{2}{*}{$\begin{array}{l}\text { Ktoś wysłał mi negatywne albo obraźliwe } \\
\text { komentarze przez coś, co umieścili w in- } \\
\text { ternecie moi rodzice (opiekunowie) }\end{array}$} & Nie & 96,5 & 58,4 \\
\hline & Tak & 3,5 & 41,6 \\
\hline
\end{tabular}

${ }^{A} X^{2}(1, N=756)=156,26 ; p<0,001 ;{ }^{B} X^{2}(1, N=755)=145,54 ; p<0,001 ;$ młodzież $w$ wieku 11-17 lat. Pytania dotyczyły doświadczeń z okresu roku poprzedzającego badanie

Wyniki wskazują na istotne statystycznie zależności między tym, czy rodzice publikują informacje o dziecku bez jego zgody, a konsekwencjami tego działania dla samego dziecka. Pierwszy wniosek z analiz jest w istocie pozytywny. Dzieci tych rodziców, którzy nigdy nie publikują w sieci informacji o swoim dziecku bez jego zgody ${ }^{5}$, same w przeważającej większości nie mają powodów do zdenerwowania $(94,4 \%)$, ani nie dostają przykrych komentarzy (96,5\%) przez coś, co ich rodzice (opiekunowie) umieścili w internecie. Inaczej jest natomiast w przypadku tych nastolatków, których rodzice, choćby tylko od czasu do czasu, publikują w sieci informacje o swoich dzieciach, nie pytając ich o zgodę. Spośród nich co drugi $(51,3 \%)$ odczuwał zdenerwowanie, a około dwóch na pięciu $(41,6 \%)$ stało się odbiorcą nieprzyjemnych komentarzy w związku z czymś, co umieścili w internecie ich rodzice (opiekunowie). Ostatecznie można przyjąć, że najlepszym sposobem chronienia własnych dzieci przed dodatkowymi przykrościami w internecie jest niepublikowanie żadnych informacji i materiałów na ich temat bez uzgodnienia tego z dzieckiem.

${ }^{5}$ Zgodnie z wiedzą pytanego dziecka. 


\section{Ważny fakt}

Około połowa nastolatków, których rodzice umieszczają w internecie informacje na temat swoich dzieci, nie pytając ich o zgodę, doświadcza związanych z tym negatywnych emocji i nieprzyjemnych komentarzy ze strony innych użytkowników sieci.

\section{Podsumowanie i wnioski}

Nieustanny - i nieuchronny - rozwój oraz wszechobecność technologii sieciowych wpływa na kontekst społeczny, ekonomiczny i prawny, a także na codzienny sposób funkcjonowania współczesnej rodziny. Dotyczy to również przemian w zakresie rozumienia i realizowania roli wychowawczej rodziców wobec dzieci i młodych osób, których świat społeczny powiększył się o wymiar „online”, nie mniejszy - a być może nawet rozleglejszy - niż ten „offline”.

Także wyniki naszych badań wskazują na zmiany technologiczne, do których muszą przystosować się i dzieci, i ich rodzice. Przykładem może być rozwój technologii mobilnych, dający swobodę łączenia się z internetem także poza domem i szkołą. Zarówno starsze, jak i młodsze dzieci chętnie z tej możliwości korzystają. W konsekwencji rodzice nie mogą już czuwać nad bezpieczeństwem dziecka poprzez samo tylko przebywanie w pobliżu, gdy jest ono aktywne w sieci.

Jak wynika z relacji młodych respondentów, spora część rodziców w Polsce podejmuje szereg różnych działań wychowawczych, starając się minimalizować zagrożenia i maksymalizować korzyści dla dzieci i młodzieży płynące z użytkowania technologii sieciowych. Najczęściej są to rozmowy z dzieckiem na temat bezpiecznego korzystania z internetu, najrzadziej zaś rodzice korzystają ze wsparcia technologicznego w postaci programów kontroli rodzicielskiej.

Optymizmem napawa też wynik pokazujący, że wiele dzieci i nastolatków nie tylko prezentuje pozytywną postawę wobec zabiegów rodzicielskich, ale też sami proaktywnie starają się tego rodzaju wsparcie od rodziców uzyskać, szczególnie kiedy nie radzą sobie z negatywnymi doświadczeniami w sieci. 
Niestety, pojawiają się też nowe zagrożenia, których - paradoksalnie - źródłem są sami rodzice. Przykładem jest tu zjawisko sharentingu, czyli nieodpowiedzialnego publikowania w internecie informacji (komentarzy zdjęć, filmów) na temat własnych dzieci, bez uprzedniego zapytania o zgodę. Oprócz oczywistego naruszenia prawa młodego człowieka do prywatności, rodzice publikujący takie materiały, choć jest ich stosunkowo niewielu, narażają swoje dzieci m.in. na przykre komentarze ze strony innych użytkowników sieci. 


\section{6. Środowisko rówieśnicze a internet}

Łukasz Tomczyk (Uniwersytet Pedagogiczny im. Komisji Edukacji Narodowej w Krakowie)

Analiza sposobów użytkowania internetu przez młode osoby jest interesująca również ze względu na zjawisko pomocy w kwestiach technicznych i społecznych, jakie zachodzi w środowisku rówieśniczym. Tytułowe pomaganie traktowane jest w niniejszym rozdziale przez pryzmat edukacji rówieśniczej. Wspomniany model edukacyjny bywa rozwiązaniem skuteczniejszym niż tradycyjny model uczenia się i nauczania realizowany pomiędzy nauczycielem a uczniem. Wysoką efektywność działań związanych z transferem wiedzy i umiejętności, a także postaw między młodymi osobami, warunkują zbliżone kody językowe oraz brak obaw o ocenę ze strony interlokutora. Młode osoby chętniej zadają pytania i prowadzą dyskusję z rówieśnikami niż z osobami dorosłymi, których opinia jest zasadniczo różna lub może być uznana za niewiarygodną (Cybula, Wieczorek, 2006). Adolescenci mogą posiadać obawy, brak zaufania oraz poczucie niskiej wiarygodności w odniesieniu do wiedzy posiadanej przez nauczycieli i rodziców. Stan ten dotyczy przede wszystkim problematyki świata cyfrowego, w którym wiele umiejętności nabywanych jest przez dzieci i młodzież naturalnie poprzez samokształcenie i edukację rówieśniczą.

Edukacja rówieśnicza może być realizowana w sposób zaplanowany lub spontaniczny. Zaangażowanie $\mathrm{w}$ przekazywanie wiedzy dotyczącej internetu wykracza poza standardowe plany nauczania i jest w większości przypadków 
powiązane z realnymi potrzebami młodych osób, które nie zostały zaspokojone poprzez tradycyjne programy nauczania, np. w ramach zajęć komputerowych czy też technologii informacyjnej. Edukacja rówieśnicza daje szansę na kompensację niedoskonałości programów nauczania i profilaktycznych, wynikających między innymi z szybkiego rozwoju usług społeczeństwa informacyjnego. Ten sposób przekazywania wiedzy i kształtowania umiejętności jest naturalną formą uczenia się, sprawdzającą się w wielu obszarach wykraczających poza kompetencje cyfrowe (Karaca, Akkus, Sener, 2018).

Dla pokolenia, które nie zna rzeczywistości innej niż społeczeństwo informacyjne, osoby dorosłe mogą jawić się jako nierozumiejące w pełni zjawisk dotykających młodych osób w przestrzeni cyfrowej. Niemniej jednak, analizując wyniki z poprzednich edycji badań EU KIDS Online, należy podkreślić, że to dorośli najczęściej pokazywali młodym osobom, w jaki sposób użytkować nowoczesne technologie (Livingstone i in., 2011). W modelu EU KIDS edukacja rówieśnicza jest jednym z rozwiązań, służących wzmocnieniu kompetencji cyfrowych w obszarze bezpieczeństwa. Równie istotnymi i komplementarnymi są poradnictwo rodzicielskie oraz działania edukacyjne realizowane w przestrzeni szkolnej (Livingstone, Mascheroni, Staksrud, 2015). Aby edukacja rówieśnicza była skuteczna, konieczne jest posiadanie kompetencji cyfrowych dotyczących obsługi mediów cyfrowych oraz umiejętności reagowania na sytuacje problematyczne, a także naturalnej chęci dzielenia się zdobytą wiedzą. W tabeli 6.1 przedstawiono procentowy rozkład odpowiedzi na pytania związane z transferem wiedzy i umiejętności oraz wsparciem dotyczącym użytkowania internetu.

Tabela 6.1. Pomoc rówieśników w obszarze użytkowania internetu

\begin{tabular}{|c|c|c|c|c|c|c|c|}
\hline Rodzaj pomocy & $\begin{array}{c}\text { Nigdy } \\
\%\end{array}$ & $\begin{array}{c}\text { Prawie } \\
\text { nigdy } \\
\%\end{array}$ & $\begin{array}{c}\text { Czasem } \\
\%\end{array}$ & $\begin{array}{c}\text { Często } \\
\%\end{array}$ & $\begin{array}{c}\text { Bardzo } \\
\text { często } \\
\%\end{array}$ & $\begin{array}{c}\text { Nie wiem } \\
+ \text { Nie chcę } \\
\text { odpowiadać } \\
\%\end{array}$ & $\begin{array}{c}\text { Różnice } \\
\%\end{array}$ \\
\hline $\begin{array}{l}\text { a) Podpowiadali Ci, } \\
\text { jak bezpiecznie } \\
\text { korzystać } \\
\text { z internetu }\end{array}$ & 36,7 & 14,4 & 14,6 & 5,1 & 3,6 & 25,5 & $\begin{array}{c}\text { Dziewczęta } \\
\text { częściej**** }\end{array}$ \\
\hline $\begin{array}{l}\text { b) Zachęcali do ko- } \\
\text { rzystania i ucze- } \\
\text { nia się rzeczy } \\
\text { z internetu }\end{array}$ & 28,3 & 16,6 & 17,6 & 7,0 & 4,2 & 26,3 & $\begin{array}{c}\text { Dziewczęta } \\
\text { częściej**** }\end{array}$ \\
\hline
\end{tabular}


c) Pomagali Ci, kiedy w internecie coś było trudno zrobić albo zna21,3 13, leźć

d) Rozmawiali z Tobą o tym, co robisz $\mathrm{w}$ inter29,1 16,2 16,9 7,4 3,8 26,6 Brak różnic necie

e) Wyjaśniali, dlaczego niektóre treści internetow 38,0 13,5 12,2 4,8 3,8

27,7

Brak różnic są dobre, a inne złe
f) Podpowiadali, jak zachowywać się w stosunku do innych osób w internecie

g) Pomogli $\mathrm{Ci}$ kiedy coś w internecie Cię zaniepokoiło w przeszłości,

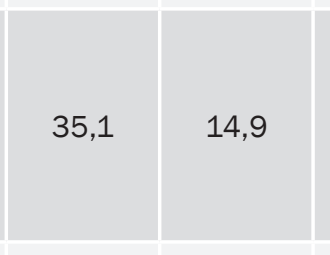

32,3

13,6

14,8

6,2

4,2

28,3

\section{Dziewczęta} częściej****

h) Ogólnie rozmawiali z Tobą o tym, co byś zrobił/a, gdyby kiedykolwiek coś w internecie Cię zaniepokoiło
33,5

13,1
6,4

4,5

29,0
Dziewczęta częściej***

$\mathrm{N}=1249$ - młodzi ludzie w wieku 9-17 lat, *p<0,05; **p<0,01; ***p<0,001, ****p<0,0001

Najczęściej młode osoby otrzymują wsparcie od kolegów i koleżanek w zakresie: trudnych do wykonania czynności lub ukrytych informacji w przestrzeni internetowej, zachęcania do korzystania i uczenia się przez internet oraz rozmów o aktywnościach podejmowanych w internecie. Prawie co czwarta ankietowana osoba nigdy nie rozmawiała z koleżankami i kolegami na temat 
dobrych i złych następstw związanych z treściami zaczerpniętymi z internetu. Równie rzadko ankietowani otrzymywali rady na temat, jak bezpiecznie korzystać z internetu, oraz podpowiadali strategie zachowywania wobec innych osób w przestrzeni sieciowej. Dziewczęta zdecydowanie częściej niż chłopcy deklarują otrzymywanie wsparcia w zakresie bezpiecznego i konstruktywnego użytkowania mediów cyfrowych (zależność ta nie jest jedynie prawdziwa dla etycznej oceny treści internetowych oraz rozmów o aktywności w sieci punkty d i e).

Wnioski z poprzednich edycji badań są spójne z obecnymi danymi. Ankietowani o wiele częściej są w stanie udzielić podpowiedzi związanej z techniczną obsługą niż e-zagrożeniami. Spójność jest również widoczna w różnicach wynikających z płci. Dziewczęta o wiele częściej udzielały pomocy rówieśniczej dotyczącej obsługi internetu. Tendencja jest spójna z poprzednimi wynikami badań EU KIDS Online (Livingstone i in., 2011).

\section{Ważny fakt}

Najczęściej młode osoby uzyskały od rówieśników pomoc w obszarze wyszukiwania treści lub wykonywania czynności powiązanych z internetem. Najrzadziej, spośród analizowanych zachowań, badani dzielili się wiedzą o etycznej ocenie treści internetowych, a także jak bezpiecznie korzystać z internetu oraz zachowywać się wobec innych. Dziewczęta zdecydowanie częściej niż chłopcy deklarują, że uczestniczą w rozmowach i otrzymują wsparcie na temat konstruktywnego i bezpiecznego użytkowania internetu.

Pomoc rówieśnicza w obszarze wzmacniania kompetencji cyfrowych może wynikać z relacji rówieśniczych oraz być powiązana z innowacyjnymi programami edukacji medialnej, które wspomagają powstanie i podtrzymywanie tego typu aktywności. Przykładem jest chociażby cykl działań Web Rangers, u podstaw którego leży założenie, że skuteczne kształtowanie kompetencji bezpiecznego użytkowania sieci może odbywać się poprzez wykorzystanie potencjału tkwiącego w młodych osobach. Podstawą dla takich działań jest wysoka pozycja socjometryczna wybranych młodych osób oraz ich kompetencje cyfrowe, a także umiejętności komunikacyjne. Web Rangers to osoby w wieku 13-15 lat zainteresowane szczególnie tematyką internetu, sieci spo- 
łecznościowych oraz przede wszystkim zmotywowane, by uczyć innych młodych użytkowników internetu, jak bezpiecznie korzystać z zasobów globalnej cyfrowej wioski. Projekt ma na celu motywowanie młodzieży do rozpowszechniania wiedzy i doświadczeń w zakresie bezpiecznego korzystania z internetu w środowisku szkolnym. Działania te realizowane są poprzez tworzenie projektów szkoleń, klipów oraz konkursów przez młode osoby dla rówieśników. Nauczyciele - koordynatorzy projektu zapewniają jedynie wsparcie organizacyjne oraz wspomagają proces działania Web Rangers w środowisku szkolnym. Przygotowanie metodyczne dla opiekunów i uczniów zapewnia w ramach zróżnicowanych form szkoleniowych zewnętrzna firma, w tym przypadku Google. Projekty edukacyjne, nad którymi pracują młode osoby, obejmują wszystkie tematy odnoszące się do bezpiecznego korzystania z sieci, natomiast sposób ich realizacji może być dowolny. Najlepsze działania są nagradzane po zakończeniu każdej z edycji. Tego typu cykliczne akcje edukacyjne skutecznie realizują na przykład eksperci z Centre for the Prevention of Risky Virtual Communication Faculty of Education of Palacký University in Olomouc - Republika Czeska (Tomczyk, Kopecky, 2016). W Polsce zbliżony projekt, bazujący na edukacji rówieśniczej, jest realizowany przez Fundację Rozwoju Społeczeństwa Informacyjnego. W ramach programu „Mądrzy Cyfrowi" młode osoby rozwijają nie tylko kompetencje cyfrowe, lecz również kształtują postawy odpowiedzialności społecznej w przestrzeniach online i offline. W przedsięwzięciu uczestniczą szkoły, biblioteki, gminne ośrodki kultury $i$ inne instytucje, których celem jest wspomaganie działalności edukacyjnej i wychowawczej młodzieży w wieku 12-13 lat. Zajęcia wprowadzające w projekt trwają 5 dni. W tym czasie młode osoby zapoznają się z aplikacjami służącymi konstruktywnemu wykorzystaniu mediów cyfrowych oraz jednocześnie pracują nad własnymi 6-tygodniowymi projektami rozwijającymi bezpieczeństwo cyfrowe w najbliższym otoczeniu. Całość działań podlega wparciu metodycznemu, które gwarantują przeszkoleni pedagodzy lub bibliotekarze, zapewniając bieżącą pomoc w realizacji projektów (FRSI, 2018).

Podsumowując, akcje edukacyjne bazujące na edukacji rówieśniczej generują pozytywne następstwa. Po pierwsze, wyniki badań zgromadzone w ramach eksperymentów związanych z transferem wiedzy i umiejętności cyfrowych sugerują, że edukacja rówieśnicza w zakresie użytkowania mediów cyfrowych podnosi nie tylko kompetencje cyfrowe odnoszące się do bezpieczeństwa, lecz również przyczynia się do wzmocnienia jakości komunikacji interpersonalnej, 
pogłębia wzajemne zrozumienie oraz poprawia relacje rówieśnicze (Korkmaz, Esen, 2013). Transfer wiedzy i umiejętności dotyczących mediów cyfrowych wśród rówieśników, włączony w jakikolwiek rodzaj edukacji (formalny, pozaformalny, nieformalny), przyczynia się do refleksji związanej ze stylem użytkowania mediów, minimalizuje złe nawyki, prowadząc do zmniejszenia zachowań ryzykownych (Korkmaz, Kiran-Esen, 2012). 


\section{Doświadczane ryzyko i poczucie bezpieczeństwa w internecie}

Katarzyna Abramczuk (Ośrodek Przetwarzania Informacji - Państwowy Instytut Badawczy)

Internet stanowi bardzo cenne źródło różnego rodzaju zasobów - od informacji, poprzez kontakty, a na rozrywce kończąc. Jednak w labiryncie tych zasobów nie brakuje ciemnych zaułków, które mogą stanowić zagrożenie nawet dla dorosłych, nie wspominając o dzieciach i młodzieży. Oczywiście jest to fakt, który przykuwa uwagę wielu badaczy, polityków i mediów. Tworzone są nowe rozwiązania mające na celu filtrowanie treści niewiarygodnych (Kąkol i in., 2013), niebezpiecznych (Wisniewski i in., 2017) albo krzywdzących (Mishna i in., 2009), a także rozwiązania chroniące sprzęt przed złośliwym oprogramowaniem (Jiang i Zhou, 2012). Badanie EU Kids Online w systematyczny sposób eksploruje, jak w świecie tych zagrożeń czują się i poruszają dzieci i młodzież. W ramach pierwszej edycji tego badania posługiwano się klasyfikacją zagrożeń online, która w nieco zmodyfikowanej postaci ${ }^{1}$ została przedstawiona w tabeli 7.1 (Livingstone i in., 2011, s. 13).

1 Livingstone i in., 2011, przyjmują, że kontakt odnosi się do uczestnictwa w aktywnościach zainicjowanych przez dorosłych, a zachowanie w aktywnościach zainicjowanych przez rówieśników (zarówno w charakterze ofiary jak i sprawcy). 
Tabela 7.1. Klasyfikacja zagrożeń w internecie

\begin{tabular}{|c|c|c|c|}
\hline Typ zagrożenia & $\begin{array}{l}\text { Treść (zawartość) - } \\
\text { bycie odbiorcą ogólnie } \\
\text { dostępnych treści }\end{array}$ & $\begin{array}{l}\text { Kontakt - uczestniczenie } \\
\text { w aktywności } \\
\text { zainicjowanej przez kogoś } \\
\text { innego }\end{array}$ & $\begin{array}{c}\text { Zachowanie - inicjowanie } \\
\text { aktywności }\end{array}$ \\
\hline Agresja & $\begin{array}{l}\text { Przemoc/okrucieństwo/ } \\
\text { sceny drastyczne }\end{array}$ & $\begin{array}{l}\text { Doznawanie dręczenia/ } \\
\text { znęcania się/agresyw- } \\
\text { ności/napastliwości ze } \\
\text { strony innych }\end{array}$ & $\begin{array}{l}\text { Dręczenie/złośliwe za- } \\
\text { chowanie/napastliwość } \\
\text { (cyberagresja) }\end{array}$ \\
\hline Seks & Pornografia & $\begin{array}{l}\text { Doświadczenie bycia } \\
\text { napasowanym seksualnie/ } \\
\text { „grooming” }\end{array}$ & $\begin{array}{l}\text { Seksting, napastowanie } \\
\text { seksualne }\end{array}$ \\
\hline Wartości & $\begin{array}{l}\text { Rasizm/nienawiść } \\
\text { (tzw. „hejt”) }\end{array}$ & Perswazja ideologiczna & $\begin{array}{l}\text { Tworzenie szkodliwych } \\
\text { treści }\end{array}$ \\
\hline Komercyjne & Marketing/perswazja & $\begin{array}{l}\text { Nadużycia prywatności/ } \\
\text { wykorzystanie danych } \\
\text { ososbistych }\end{array}$ & $\begin{array}{l}\text { Naruszanie praw autor- } \\
\text { skich/hazard online }\end{array}$ \\
\hline
\end{tabular}

Autorzy klasyfikacji chcieli zwrócić uwagę na to, że w kontekście zagrożeń szczególnie istotne są dwa aspekty: poruszana tematyka (por. kolejne wiersze tabeli) oraz rola, jaką przyjmuje młody człowiek - użytkownik nowych mediów. Użytkownik może występować w biernej roli odbiorcy tego, co się w sieci znajduje. Może uczestniczyć mimowolnie w trudnych sytuacjach, często w charakterze ofiary. Może w końcu sam być stroną aktywną, produkującą określone treści, prowokującą określone sytuacje, czy też naruszającą zasady. W tym rozdziale analizowane są doświadczenia i relacje młodych ludzi, dotyczące sytuacji, w których badany mógł być odbiorcą, świadkiem lub ofiarą zagrożenia płynącego z sieci.

\section{Narażenie na ryzykowne i szkodliwe treści i oprogramowanie}

Szkodliwe treści w internecie są tematem bardzo medialnym. Przez debatę publiczną przetoczyło się kilka fal ostrzeżeń przed tym, jak łatwo znaleźć w sieci niebezpieczne informacje i obrazy mające związek z przemocą i autodestrukcją. Przykładowo w 2017 roku głośno było o grze Niebieski Wieloryb (ang. Blue Whale), która miała prowadzić do samobójstw nastolatków. Problem był na tyle 
szeroko dyskutowany, że Ministerstwo Edukacji Narodowej zdecydowało się wystosować list ostrzegawczy do placówek oświaty. W 2018 roku efekt swoistej paniki wywołały doniesienia o lalce MOMO.

W badaniu EU Kids pytano młodych ludzi powyżej 10. roku życia, jak często w ciągu minionego roku mieli styczność z różnego rodzaju szkodliwymi treściami. Chodziło o treści, które mogą prowadzić do samouszkodzenia lub wyrządzenia krzywdy innym ludziom bądź zwierzętom. Lista treści, o jakie pytano, jest widoczna na wykresie 7.1.

Wykres 7.1. Ekspozycja na szkodliwe treści w internecie: Czy w ciągu ostatniego roku widziałeś/aś w internecie takie treści?

Krwawe albo brutalne obrazy, np. ludzi robiących krzywdę innym ludziom albo zwierzętom

Doświadczenia z braniem narkotyków

Tzw. hejt, treści zawierające nienawiść wobec pewnych osób lub grup

To, jak stać się bardzo szczupłym (takie jak prowokowanie anoreksji, bulimii albo innych niezdrowych zachowań)

To, jak popełnić samobójstwo

To, jak się zranić lub zrobić sobie samemu krzywdę fizyczną

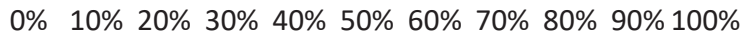
Nie miałem(am) Miałem(am)

Nie wiem/trudno powiedzieć/ wolę nie odpowiadać

$\mathrm{N}=928$ (11-17 lat)

Po pierwsze należy zauważyć, że wszystkie rodzaje szkodliwych treści są dość powszechnie dostępne. We wszystkich przypadkach mniej więcej jeden na pięciu nastolatków udzielił wymijającej odpowiedzi (nie wiem/trudno powiedzieć lub wolę nie odpowiadać). Pośród tych, którzy udzielili zdecydowanych odpowiedzi w przypadku każdego rodzaju treści, około połowa deklarowała, że 
miała styczność z danym typem przekazu. Najwięcej młodych ludzi wskazało, że spotkało się z mową nienawiści (48\% wszystkich, którym zadano to pytanie), a najmniej, że widziało treści dotyczące sposobów na popełnienie samobójstwa. Wciąż jednak było to aż 37\% pytanych.

Tylko 28\% nastolatków zadeklarowało jednoznacznie, że nie zetknęło się z żadnym z wymienionych rodzajów szkodliwych treści. Udział ten wyraźnie spada z wiekiem: dla nastolatków w wieku 11-12 lat wyniósł 42\%, w wieku 13-14 lat - 24\%, a dla najstarszych, w wieku 15-17 lat, jedynie 20\%. Z drugiej strony $28 \%$ badanych zadeklarowało jednoznacznie, że miało styczność ze wszystkimi wymienionymi rodzajami szkodliwych treści. Udział ten rośnie z wiekiem. Wśród najmłodszych wynosi 14\%, wśród 13- i 14-latków 30\%, a wśród najstarszych aż 38\%.

\section{Ważny fakt}

Zdecydowana większość badanych nastolatków (w wieku 11-17 lat) ma styczność z różnego rodzaju szkodliwymi treściami w internecie. Dotyczy to zwłaszcza starszej młodzieży. Tylko 28\% nastolatków zadeklarowało jednoznacznie, że nie miało styczności z żadnym z wymienionych rodzajów szkodliwych treści.

Jednymi z często dyskutowanych zagrożeń związanych z użytkowaniem internetu są zagrożenia prywatności. Wychowani w dobie spersonalizowanego marketingu, wycieków danych, niebezpiecznego spamu zalewającego skrzynki pocztowe i debaty publicznej o granicach dopuszczalnego monitorowania internetu przez służby specjalne, młodzi ludzie mogą być o wiele bardziej niż starsze pokolenia świadomi tego, że poruszając się po sieci, narażają swoją prywatność i mogą zostać oszukani. Może z ich ostrożności wynika, że zdecydowana mniejszość badanych doświadczyła jakiegoś rodzaju zagrożeń w sferze prywatności i oszustw internetowych. Szczegółowe dane prezentuje wykres 7.2. Odnosi się on do zagrożeń, które miały miejsce w ciągu roku poprzedzającego badanie. 
Wykres 7.2. Ekspozycja na zagrożenia prywatności w internecie: Czy w ciągu ostatniego roku przydarzyły Ci się takie sytuacje?

Ktoś dowiedział się, gdzie jestem, bo śledził mój telefon komórkowy lub inne urządzenie

Wydałem zbyt dużo pieniędzy na zakup aplikacji lub w grach komputerowych

Ktoś zrobił stronę lub rozesłał nieprzyjemne zdjęcie/filmik przedstawiające mnie

Ktoś użył mojego hasła, żeby mieć dostęp do moich danych lub żeby udawać, że jest mną Straciłem pieniądze, bo ktoś oszukał mnie w internecie

Miałem wirusa lub inne złośliwe oprogramowanie na moim urządzeniu (laptopie, komputerze, telefonie)

Ktoś użył moich osobistych informacji w sposób, który mi się nie spodobał

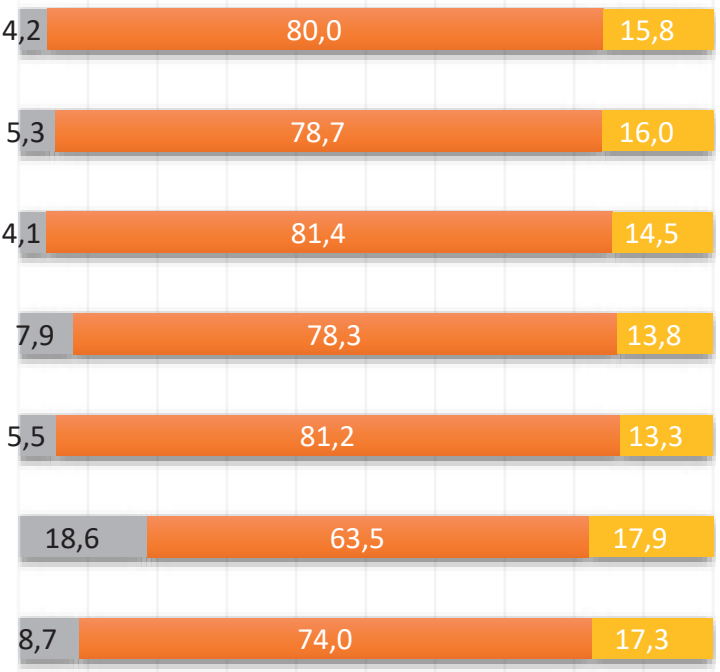

$\begin{array}{llllllllllll}0 \% & 10 \% & 20 \% & 30 \% & 40 \% & 50 \% & 60 \% & 70 \% & 80 \% & 90 \% & 100 \%\end{array}$

- Tak $\square$ Nie $\square$ Nie wiem/trudno powiedzieć/ wolę nie odpowiadać

$\mathrm{N}=1249$ (9-17 lat)

Najczęściej doświadczanym zagrożeniem z tej kategorii jest złośliwe oprogramowanie, z którym świadomy kontakt w ciągu roku przed badaniem miało prawie 20\% uczestników sondażu. Kolejnym zagrożeniem, jeśli chodzi o powszechność, jest użycie osobistych informacji w sposób niezgodny z wolą osoby, do której się odnosiły. Dotyczy ono 9\% wszystkich pytanych. Osiem procent w tej grupie przyznaje, że wie, iż ktoś użył ich hasła, aby uzyskać dostęp do ich danych lub się pod nich podszywać. Ogólnie jednak 70\% respondentów nie zadeklarowało jednoznacznie, że miało do czynienia z którymkolwiek z wymienionych zagrożeń. Jeśli wyłączymy ze spisu styczność z wirusami komputerowymi, jest to aż $80 \%$. 


\section{Ważny fakt}

Zdecydowanej większości młodych ludzi udaje się uniknąć poważnych naruszeń prywatności i oszustw internetowych. Najpowszechniejszymi zagrożeniami w tej dziedzinie, oprócz styczności ze złośliwym oprogramowaniem, są nadużycie osobistych informacji i uzyskanie dostępu do prywatnych haseł.

Udział osób, które doświadczyły zagrożeń prywatności i oszustw internetowych wzrasta z wiekiem. Z badań wynika, że około 20\% dzieci do 10. roku życia, 26\% nastolatków w wieku 11-12 lat, 35\% nastolatków w wieku 13-14 lat i prawie 39\% najstarszych respondentów doświadczyło któregoś z zagrożeń wymienionych na wykresie 7.2.

\section{Zagrożenia związane z nawiązywaniem nowych znajomości i autoprezentacją}

Kolejne zagrożenie związane z internetem, które jest stosunkowo szeroko dyskutowane, wynika z nawiązywania nowych znajomości przez sieć. Powstało kilka teorii dotyczących tego zjawiska (Barbovschi i in., 2012). Przykładowo teoria kompensacji społecznej (ang. social compensation hypothesis - Tsao, 1996; Livingstone i Helsper, 2007) głosi, że część bardziej introwertywnej młodzieży szuka znajomości online, aby „wynagrodzić” sobie słabe kontakty społeczne poza siecią. Z kolei teoria namnażania ${ }^{2}$ (ang. 'rich get richer' model - Kraut i in., 2002; McKenna, Green i Gleason, 2002) mówi, że dzieci i młodzież o intensywnej sieci kontaktów stosują podobne skrypty zachowań w internecie i poza nim, przez co osoby o szerokiej sieci społecznej częściej nawiązują znajomości online.

Nawiązywanie znajomości online rodzi wiele nowych zagrożeń. Jednak badanie EU Kids Online 2010 wykazało, że są one stosunkowo rzadkie (Barbovschi i in., 2012). Do podobnego wniosku skłania badanie z 2018 roku.

2 Terminologia własna. 
Wykres 7.3. Interakcje z nieznajomymi w internecie. Częstość zachowań w ciągu ostatniego roku.

Wysłałem/am swoje zdjęcie albo filmik ze mną komuś, z kim nigdy wcześniej nie spotkałem/am się twarzą w twarz

Udawałem/am w internecie, że jestem kimś innym niż w rzeczywistości

Dodałem/am do listy znajomych lub listy kontaktów kogoś, z kim nigdy wcześniej nie spotkałem/am się twarzą w twarz

Wysłałem/am informacje o sobie (np. imię i nazwisko, adres albo numer telefonu) komuś, z kim nigdy wcześniej nie spotkałem/am się twarzą w twarz

Szukałem/am nowych przyjaciół albo znajomych w internecie

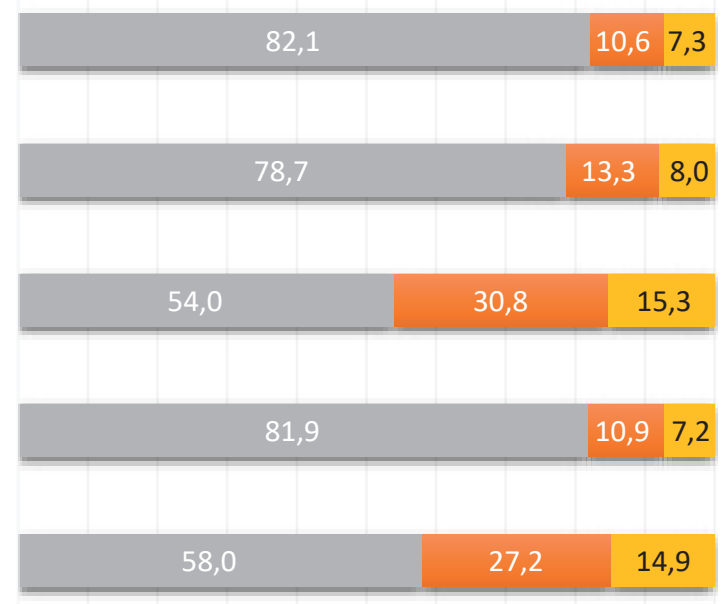

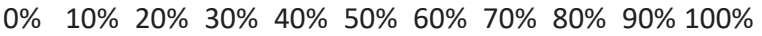

Nigdy $\quad$ Kilka razy $\square$ Raz w miesiącu lub częściej

N=1237 (11-17 lat), z wyłączeniem braków i odpowiedzi „nie wiem/trudno powiedzieć” lub „wolę nie odpowiadać”

Przede wszystkim najmłodsi są stosunkowo ostrożni, jeśli chodzi o udostępnianie informacji o sobie (patrz wykres 7.3). Spośród badanych, którzy udzielili informacji o częstości tego zachowania, 82\% stwierdziło, że nigdy nie wysyła obcym swoich zdjęć lub filmików. Także 82\% respondentów zadeklarowało, że nigdy nie wysyła obcym informacji o sobie, takich jak imię, nazwisko czy numer telefonu. Ryzykiem z tej kategorii, najczęściej podejmowanym przez młodzież, jest dodawanie do listy znajomych bądź kontaktów osób niespotkanych wcześniej poza siecią oraz poszukiwanie nowych znajomości w internecie.

\section{Ważny fakt}

Nieco mniej niż połowa badanych nastolatków (w wieku 11-17 lat) szuka nowych znajomości w internecie. Towarzyszy temu wyraźna ostrożność w kwestii dzielenia się swoimi danymi prywatnymi. 
Częstotliwość wszystkich wymienionych zachowań ryzykownych rośnie z wiekiem, co ilustruje tabela 7.2. Pokazuje ona udział respondentów, którzy zadeklarowali, że w ciągu ostatniego roku podejmowali daną czynność (bez uwzględnienia częstotliwości jej podejmowania). Udział badanych szukających nowych znajomości w sieci wzrasta o 15 punktów procentowych między 10. a 11. rokiem życia. Udział tych, którzy dodają nieznajomych do swoich kontaktów także wzrasta w tym okresie o 15 punktów procentowych, a między 12. a 13. rokiem życia obserwujemy wzrost o dalsze 22 punkty procentowe. Udział badanych, którym zdarzyło się wysłać komuś obcemu swoje zdjęcie lub filmik, wzrasta między 12. a 13. rokiem życia o 9 punktów procentowych, a między 14. a 15. rokiem życia o dalsze 10 punktów procentowych. Dziewczęta częściej niż chłopcy szukają nowych znajomych w sieci. Ta różnica między chłopcami a dziewczętami pojawia się wśród dzieci po 12. roku życia.

Tabela 7.2. Udział badanych w rozbiciu na grupy wiekowe i płeć, którzy zadeklarowali, że w ciągu ostatniego roku podejmowali dane działanie

\begin{tabular}{|c|c|c|c|c|c|c|}
\hline & $\begin{array}{c}9-10 \text { lat } \\
\%\end{array}$ & $\begin{array}{l}11-12 \\
\text { lat } \%\end{array}$ & $\begin{array}{c}\text { 13-14 lat } \\
\%\end{array}$ & $\begin{array}{c}15-17 \text { lat } \\
\%\end{array}$ & $\begin{array}{c}\text { chłopcy } \\
\%\end{array}$ & $\begin{array}{c}\text { dziewczęta } \\
\%\end{array}$ \\
\hline $\begin{array}{l}\text { Szukałem/am nowych przyjaciół } \\
\text { albo znajomych w internecie }\end{array}$ & 26,6 & 41,2 & 46,4 & 51,7 & 37,5 & 46,1 \\
\hline $\begin{array}{l}\text { Wysłałem/am informacje o sobie } \\
\text { (np. imię i nazwisko, adres albo } \\
\text { numer telefonu) komuś, z kim } \\
\text { nigdy wcześniej nie spotkałem/ } \\
\text { am się twarzą w twarz }\end{array}$ & 11,6 & 15,0 & 19,2 & 25,9 & 19,5 & 16,9 \\
\hline $\begin{array}{l}\text { Dodałem/am do listy znajomych } \\
\text { lub listy kontaktów kogoś, z kim } \\
\text { nigdy wcześniej nie spotkałem/ } \\
\text { am się twarzą w twarz }\end{array}$ & 21,7 & 37,2 & 59,0 & 62,8 & 44,8 & 47,2 \\
\hline $\begin{array}{l}\text { Udawałem/am w internecie, } \\
\text { że jestem kimś innym niż w } \\
\text { rzeczywistości }\end{array}$ & 18,3 & 17,4 & 24,5 & 24,8 & 23,4 & 19,4 \\
\hline $\begin{array}{l}\text { Wysłałem/am swoje zdjęcie } \\
\text { albo filmik ze mną komuś, z kim } \\
\text { nigdy wcześniej nie spotkałem/ } \\
\text { am się twarzą w twarz }\end{array}$ & 11,4 & 10,4 & 19,7 & 29,7 & 17,0 & 18,6 \\
\hline
\end{tabular}

N=1237 (9-17 lat) z wyłączeniem braków i odpowiedzi „nie wiem/trudno powiedzieć” lub „wolę nie odpowiadać” 
Podobna różnica między chłopcami i dziewczętami jest widoczna, gdy pytamy, czy badani mieli w internecie kontakt z nieznajomymi. Wśród tych, którzy zdecydowanie wypowiedzieli się w tej kwestii (bez kategorii „nie wiem/ trudno powiedzieć" oraz "wolę nie odpowiadać”), 44\% udzieliło odpowiedzi twierdzącej. Udział respondentów, którzy mieli kontakt z nieznajomymi przez sieć wyraźnie rośnie z wiekiem. Dla najmłodszych wynosi zaledwie 14\%, dla nastolatków w wieku 11-12 lat to 31\%, dla młodzieży w wieku 13-14 lat 57\%, a dla najstarszych aż $70 \%$. Wśród dzieci poniżej 13. roku życia zjawisko to częściej dotyczy chłopców, a wśród dzieci starszych - dziewcząt.

Aż 52\% osób, które zadeklarowały, że miały kontakt z nieznajomymi w sieci, potwierdziło, że spotkało się z nimi osobiście. Częściej zdarzało się to dziewczętom (55\% vs $48 \%$ ). Wśród badanych, którzy spotkali się osobiście z ludźmi poznanymi przez internet 55\% deklaruje, że cieszyło się z takiego ostatniego spotkania, a 30\% twierdzi, że było po nim zdenerwowane. Przewaga zadowolonych nad zdenerwowanymi jest największa wśród dzieci w wieku 11-12 lat (48 punktów procentowych) i wyraźnie najmniejsza w grupie najstarszej (jedynie 10 punktów procentowych). Wydaje się zatem, że spotkania z nieznajomymi stają się trudniejszym doświadczeniem po przekroczeniu 14. roku życia. Z drugiej strony, trwałość uczuć pozytywnych po osobistym spotkaniu z osobą poznaną przez internet jest wyraźnie większa niż trwałość uczuć negatywnych. Jedynie 17\% osób, które cieszyły się ze spotkania, stwierdziło, że uczucie to minęło właściwie od razu, podczas gdy analogiczny odsetek dla osób, które były spotkaniem zdenerwowane, wynosił prawie $80 \%$.

\section{Ważny fakt}

Połowa nastolatków (w wieku 11-17 lat), którzy nawiązują nowe znajomości przez internet, przenosi je potem poza sieć. Mniej więcej jedno na trzy takie spotkania kończy się przykrymi emocjami, które jednak mają charakter krótkotrwały. Połowa takich spotkań kończy się pozytywnie i ten pozytywny efekt utrzymuje się przez jakiś czas. 
Wykres 7.4. Interakcje z nieznajomymi w internecie. Spotkania osobiste i ich konsekwencje emocjonalne. Reakcja emocjonalna jest oznaczona jako nietrwała, jeżeli ustała od razu po spotkaniu.

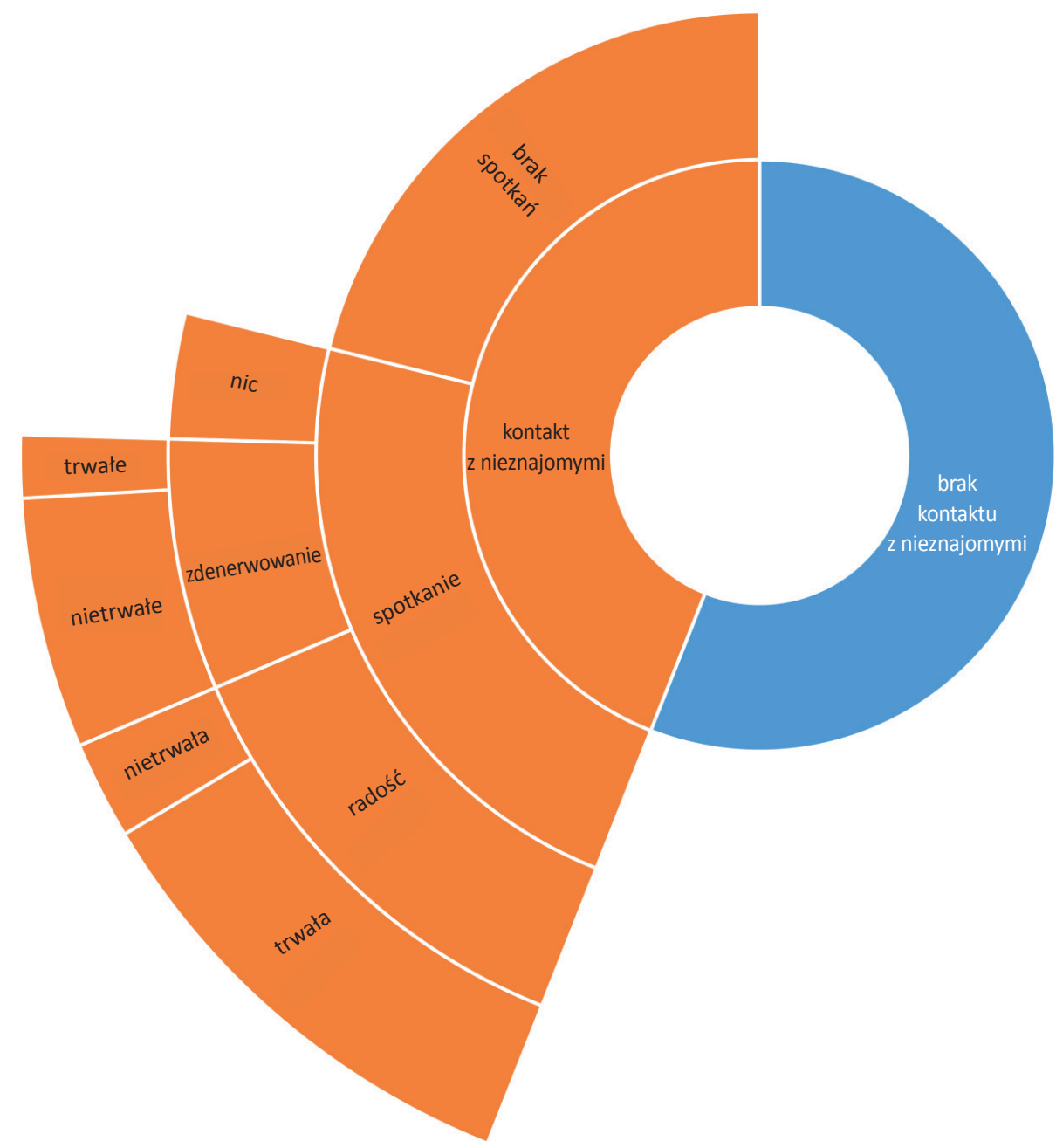

N=1084 (11-17 lat), z wyłączeniem braków i odpowiedzi „nie wiem/trudno powiedzieć” lub „wolę nie odpowiadać”. Reakcja emocjonalna jest oznaczona jako nietrwała, jeżeli ustała od razu po spotkaniu.

\section{Przykre doświadczenia i poczucie bezpieczeństwa w internecie}

Wziąwszy pod uwagę powszechność doświadczeń ze złymi treściami w internecie, świadomość zagrożeń prywatności i stosunkowo częste nawiązywanie nowych znajomości w sieci, należy się spodziewać, że młodzi ludzie mają za 
sobą jakieś przykre doświadczenia związane z użytkowaniem sieci. Dwadzieścia procent z nich potwierdziło tę tezę, gdy zostali o to zapytani wprost. Udział osób, które otwarcie przyznają, że w ciągu ostatniego roku przydarzyło się im online coś, co ich zaniepokoiło, rośnie wraz z wiekiem. Dla dzieci w wieku 9-10 lat wynosi on 13\%, w wieku 11-12 lat - 19\%, dla młodzieży w wieku 13-14 lat - 21\%, a w grupie najstarszej aż $28 \%$. Nie ma tu różnic ze względu na płeć. W większości wspomniane przykre wydarzenia stanowią jednorazowe przypadki. Wśród badanych 70\% respondentów, którzy przyznali, że przydarzyło im się coś takiego, na pytanie, jak często miało to miejsce, odpowiedzieli, że nie więcej niż kilka razy. Ciekawy wyjątek stanowią tu dzieci najmłodsze, które częściej wskazywały na powtarzające się problemy tego rodzaju. Jednak badana grupa była w tym wypadku za mała, aby wyciągać dalej idące wnioski.

Mimo przykrych doświadczeń większość młodych ludzi czuje się w internecie bezpiecznie: $65 \%$ z nich deklaruje, że jest tak często lub zawsze, $66 \%$ - że często lub zawsze wie, co zrobić, gdy ktoś zachowuje się w sieci w sposób, który im nie odpowiada. Jednocześnie jednak $70 \%$ rzadko lub nigdy nie uważa, że inni ludzie w sieci są mili i pomocni. Udział ten jest mniejszy wśród badanych, którzy deklarują, że czują się w sieci bezpiecznie i wśród tych, którzy twierdzą, że wiedzą, jak się zachować w trudnej sytuacji (gdy ktoś zachowuje się w sieci w nieodpowiadający im sposób).

\section{Ważny fakt}

Internet stanowi dla młodych ludzi przestrzeń bezpieczną, ale wyraźnie publiczną.

Warto jednak zauważyć, że postawy te są różne w różnych grupach wiekowych. Starsze dzieci częściej czują się w sieci pewnie i częściej otwierają się online. Wykres 7.5 pokazuje, że wraz z wiekiem wzrasta też przekonanie, że ludzie $w$ internecie są mili i pomocni oraz wiara we własne umiejętności radzenia sobie w sytuacji, gdy ktoś zachowuje się w sieci w nieodpowiadający danej osobie sposób. Wydaje się także, że młodzież w wieku 13-14 lat oraz chłopcy są szczególnie skłonni do dzielenia się w sieci swoimi prywatnymi historiami. 
Wykres 7.5. Udział badanych w podziale na grupy wiekowe, którzy zadeklarowali, że dane stwierdzenie dotyczy ich często lub zawsze

W internecie rozmawiam o sprawach osobistych, których nie ujawniam ludziom, kiedy rozmawiam z nimi twarzą w twarz

W internecie rozmawiam o innych rzeczach, niż wtedy, gdy spotykam się z ludźmi twarzą w twarz

Łatwiej mi być sobą w internecie niż wtedy, gdy spotykam się z ludźmi twarzą w twarz

Wiem, co zrobić, jeśli ktoś zachowuje się w internecie w sposób, który mi się nie podoba

Uważam, że ludzie których spotykam w internecie są mili i pomocni

Czuję się bezpiecznie w internecie
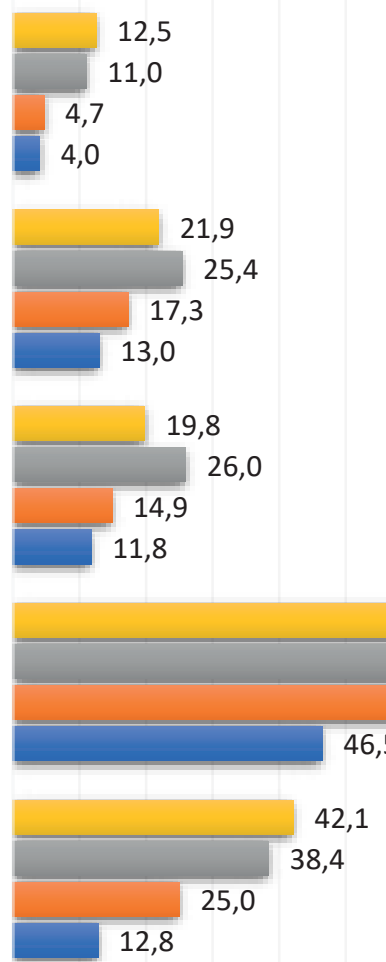

12,8

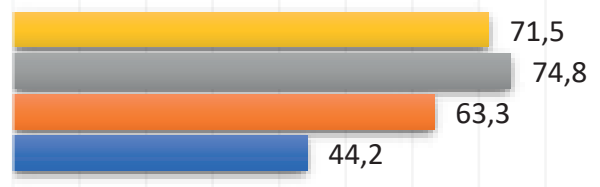

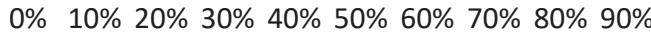

$\square 15-17 \quad 13-14 \quad \square 11-12 \quad \square 9-10$

N=1249 (11-17 lat), z wyłączeniem braków i odpowiedzi „nie wiem/trudno powiedzieć” lub „wolę nie odpowiadać”

\section{Sposoby radzenia sobie $z$ trudnymi sytuacjami w internecie}

Ostatnie pytanie, na jakie spróbuje odpowiedzieć ten rozdział, dotyczy zagadnienia, jak dzieci i młodzież radzą sobie ze spotykającymi ich w internecie trudnymi sytuacjami. W badaniu EU Kids Online sytuacje takie mają miejsce wówczas, 
gdy zdarza się coś niepokojącego, co sprawia, że badany poczuł się nieswojo, zrobiło mu się nieprzyjemnie albo miał poczucie, że nie powinien czegoś oglądać. Prawie 38\% respondentów nie wskazało żadnej swojej reakcji na taki problem, a wśród tych, którzy wskazali, około połowa wybrała przynajmniej trzy. Jednak często miały one charakter ucieczkowy (patrz tabela 7.3). Najczęściej wymieniano zamknięcie problematycznej aplikacji bądź okna w programie (62\% wskazań) i zignorowanie problemu (57\% wskazań). Wśród badanych 52\% zablokowało osobę sprawiającą im problemy. Połowa starała się sprawić, by taka osoba pozostawiła ich w spokoju. Część (16\%) odpowiadających dzieci zadeklarowało, że po przykrym incydencie przestało na jakiś czas używać internetu. Odpowiedź ta była wybierana najczęściej przez dzieci najmłodsze, poniżej 11. roku życia (40\% wskazań w tej grupie).

Tabela 7.3. Reakcja na niepokojące doświadczenie w internecie

\begin{tabular}{|l|l|}
\hline & Procent obserwacji \\
\hline Zignorowałem/am problem lub miałem/am nadzieję, że problem minie sam & 56,7 \\
\hline Zamknąłem/am okno w programie lub aplikację & 61,8 \\
\hline Czułem/am się trochę winny/winna tego, co się stało & 29,9 \\
\hline Starałem/am się sprawić, żeby ta osoba zostawiła mnie w spokoju & 50,3 \\
\hline Starałem/am się zemścić, odegrać na tej osobie & 14,6 \\
\hline Przez jakiś czas przestałem/am korzystać z internetu & 15,9 \\
\hline Skasowałem/am wszystkie wiadomości od tej osoby & 24,8 \\
\hline Zmieniłem/am swoje ustawienia prywatności/kontaktów & 29,9 \\
\hline Zablokowałem/am tę osobę & 52,2 \\
\hline Zgłosiłem/am problem (np. nacisnąłem przycisk “Zgłoś nadużycie”), \\
\hline skontaktowałem/am się z administratorem strony albo dostawcą internetu
\end{tabular}

Pytanie zadano tylko osobom, które zadeklarowały, że w ciągu ostatniego roku doświadczyły czegoś niepokojącego w internecie. Procenty nie sumują się do 100, gdyż jedna osoba mogła wskazać więcej niż jedną odpowiedź. 
Ważny fakt

W obliczu niepokojącej sytuacji w internecie dzieci i młodzież najczęściej wycofują się z niej, licząc na to, że problem rozwiąże się sam.

Ciekawe jest, czy młodzi ludzie, mierzący się z trudnymi sytuacjami w internecie, szukają jakiegoś wsparcia, a jeśli tak, to u kogo. Okazuje się, że ponad 38\% badanych, którzy doświadczyli czegoś nieprzyjemnego w sieci, nie wskazało żadnej osoby, z którą by o tym rozmawiali. Szczególnie mało skłonni do dzielenia się swoimi problemami okazali się chłopcy - 46\% z nich nie wskazało żadnego powiernika.

Wśród respondentów wskazujących jakieś osoby, z którymi rozmawiali o trudnej sytuacji, jaka spotkała ich w internecie, zdecydowanie najpopularniejszą grupą powierników okazali się rówieśnicy (72\% wskazań). Rodzice znaleźli się na drugim miejscu. Jednak zwracał się do nich wyraźnie mniejszy odsetek badanych (32\% wskazań). Nauczyciele i osoby zawodowo zajmujące się pomaganiem dzieciom i młodzieży znalazły się na końcu, po rodzeństwie, pozostałych dorosłych, a nawet „kimś innym” (patrz tabela 7.4).

Tabela 7.4. Rozmowa po niepokojącym doświadczeniu w internecie

\begin{tabular}{|l|c|}
\hline Mama lub tata (albo przybrana mama / przybrany tata) & $\%$ \\
\hline Brat lub siostra (albo przybrane rodzeństwo) & 31,6 \\
\hline Kolega lub koleżanka w moim wieku & 23,6 \\
\hline Nauczyciel lub nauczycielka & 72,4 \\
\hline $\begin{array}{l}\text { Osoba, która zawodowo pomaga dzieciom (np. policjant, pedagog, pracownik } \\
\text { socjalny) }\end{array}$ & 8,0 \\
\hline $\begin{array}{l}\text { Inna osoba dorosła, do której mam zaufanie } \\
\text { Ktoś inny }\end{array}$ & 5,7 \\
\hline $\begin{array}{l}\text { Pytanie zadano tylko osobom, które zadeklarowały, że w ciągu ostatniego roku doświadczyły czegoś niepokojącego } \\
\text { w internecie. Procenty nie sumują się do 100, gdyż jedna osoba mogła wskazać więcej niż jedną odpowiedź. }\end{array}$
\end{tabular}


Dzieci powyżej 12. roku życia trochę częściej niż młodsze zwracają się do rówieśników. Dzieci młodsze niż 13 lat wyraźnie częściej zwracają się do rodziców. Jednak we wszystkich grupach wiekowych rówieśnicy pozostają bezsprzecznie najczęściej wybieranymi powiernikami.

\section{Ważny fakt}

W obliczu niepokojącej sytuacji w internecie dzieci i młodzież najczęściej zwracają się do swoich rówieśników. 



\section{Problematyczne Użytkowanie Internetu (PUI)}

Łukasz Tomczyk (Uniwersytet Pedagogiczny im. Komisji Edukacji Narodowej w Krakowie)

Obecnie internet stał się jednym z podstawowych narzędzi pracy i rozrywki. Sytuacja ta generuje wiele pozytywnych szans oraz wyzwala negatywne zjawiska, chociażby takie jak Problematyczne Użytkowanie Internetu (PUI). PUI jest zaburzeniem zachowania związanym z nadużywaniem urządzeń elektronicznych w celu korzystania z aplikacji i stron internetowych. PUI upośledza także konstruktywne używanie nowych mediów, przyczyniając się do zmian psychospołecznego funkcjonowania. Zjawisko to może również wynikać z deficytów psychospołecznych. Do tej pory w ramach Międzynarodowej Klasyfikacji Chorób (ang. - International Statistical Classification of Diseases and Related Health Problems ICD) uzgodniono, że skrajny hazard internetowy oraz niekontrolowane zanurzenie w świecie gier jest traktowane jako zaburzenie. Uzależnienie od internetu, choć często używane, ze względu na nieostre kryteria nie zostało jednak wpisane na listę chorób. Niemniej od lat toczy się dyskusja nad nadmiernym, niekontrolowanym używaniem: portali społecznościowych, korzystaniem z serwisów strumieniowego przesyłania plików, zakupami internetowymi czy też kompulsywnymi zachowaniami seksualnymi zapośredniczonymi przez internet. W celu opracowania jednoznacznej definicji PUl, czy też uzależnienia od internetu, potrzebne są dalsze badania w zakresie uściślenia kryteriów zaburzeń, walidacji narzędzi klinicznych, uzgodnienia 
spójnych wartości diagnostycznych, biologicznych determinantów uzależnienia od sieci, skali zjawiska oraz następstw. Konieczne jest również empiryczne potwierdzenie skuteczności nurtów terapeutycznych, uwzględniających zróżnicowanie również ze względu na uwarunkowania kulturowe (Finebergi in., 2018). W tabeli nr 8.1 zaprezentowano siedem symptomów PUI, odnoszących się do czasu wolnego oraz obowiązków szkolnych. Przedstawione w tabeli faktory są spójne z pionierskimi badaniami prowadzonymi przez K. Young (2017).

Tabela 8.1. Jak często w OSTATNIM ROKU przydarzały Ci się sytuacje wymienione poniżej? ZAZNACZ WŁAŚCIWĄ ODPOWIEDŹ W KAŻDYM WIERSZU

\begin{tabular}{|c|c|c|c|c|c|c|c|}
\hline & Symptomy PUI & $\begin{array}{c}\text { Ani } \\
\text { razu } \\
\%\end{array}$ & $\begin{array}{l}\text { Kilka } \\
\text { razy } \\
\%\end{array}$ & $\begin{array}{c}\text { Raz } \\
\text { w miesiącu } \\
\%\end{array}$ & $\begin{array}{c}\text { Raz } \\
\text { w tygodniu } \\
\%\end{array}$ & $\begin{array}{l}\text { Codziennie } \\
\text { lub } \\
\text { prawie } \\
\text { codziennie } \\
\%\end{array}$ & $\begin{array}{c}\text { Nie wiem } \\
+ \text { trudno powie- } \\
\text { dzieć oraz } \\
\text { nie chcę udzielić } \\
\text { odpowiedzi } \\
\%\end{array}$ \\
\hline a) & $\begin{array}{l}\text { Zaniedbywałem/am jedze- } \\
\text { nie lub spanie z powodu } \\
\text { internetu }\end{array}$ & 64,1 & 14,3 & 1,7 & 2,2 & 1,8 & 15,8 \\
\hline b) & $\begin{array}{l}\text { Nudziłem/am się, kiedy nie } \\
\text { miałem/am dostępu do } \\
\text { internetu }\end{array}$ & 25,1 & 41,9 & 5,2 & 4,7 & 6,4 & 16,8 \\
\hline c) & $\begin{array}{l}\text { Używałem/am internetu, } \\
\text { mimo że nie byłem/am tym } \\
\text { tak naprawdę zainteresowa- } \\
\text { ny/a }\end{array}$ & 34,0 & 30,4 & 4,3 & 5,8 & 7,0 & 18,6 \\
\hline d) & $\begin{array}{l}\text { Z powodu internetu spę- } \\
\text { dzałem/am mniej czasu } \\
\text { ze znajomymi, rodziną lub } \\
\text { zaniedbywałem/am naukę }\end{array}$ & 43,6 & 26,5 & 4,0 & 4,0 & 4,4 & 17,7 \\
\hline e) & $\begin{array}{l}\text { Próbowałem/am bezsku- } \\
\text { tecznie spędzać mniej cza- } \\
\text { su w internecie }\end{array}$ & 47,7 & 23,4 & 3,6 & 3,1 & 3,1 & 19,1 \\
\hline f) & $\begin{array}{l}\text { Miałem konflikty z rodzina/ } \\
\text { przyjaciółmi z powodu cza- } \\
\text { su spędzanego w internecie }\end{array}$ & 56,3 & 19,4 & 2,7 & 2,4 & 1,4 & 17,7 \\
\hline g) & $\begin{array}{l}\text { Uważam, że to, ile czasu } \\
\text { spędzam w internecie po- } \\
\text { woduje problemy }\end{array}$ & 50,1 & 17,2 & 4,4 & 2,5 & 3,4 & 22,5 \\
\hline
\end{tabular}


Co piąty nastolatek, chociaż jeden raz w roku lub częściej zrezygnował ze spania lub posiłku na rzecz korzystania z internetu. Najczęstszym czynnikiem, który powoduje, że adolescenci są zalogowani zbyt długo w sieci jest nuda. Niespełna 13\% młodych osób objętych badaniem zaznaczyło, że minimum raz w tygodniu używa internetu, pomimo że nie ma konkretnej potrzeby bycia online. Ponad $8 \%$ minimum raz w tygodniu rezygnuje ze spotkań ze znajomymi, rodziną lub zaniedbuje naukę na rzecz korzystania z internetu. Niespełna 10\% w ciągu roku poprzedzającego badanie próbowało bezskutecznie ograniczyć korzystanie z internetu raz w miesiącu lub częściej. Codzienny konflikt związany z ograniczeniem użytkowania sieci dotyczy jedynie 1,4\% ankietowanych, natomiast 2,4\% miewa odmienne zdanie co do czasu spędzanego online, niż wynika to z oceny kolegów lub rodziny. Co czwarty nastolatek uważa, że czas spędzany w sieci może powodować problemy - w tej grupie niespełna 6\% młodych osób miewa tego typu myśli minimum raz w tygodniu. Najczęściej PUI powiązane jest z brakiem alternatyw spędzania wolnego czasu oraz samokontroli. Kwestie te powinny być szczególnie uwzględnione w konstruowaniu programów profilaktycznych ograniczających PUI.

Analizując występowanie PUI, przyjęto założenie, że ten rodzaj zachowania ryzykownego należy ukazać nie tylko poprzez obecność danego symptomu (siedem kategorii z tabeli 8.1), lecz należy uwzględnić również częstotliwość pojawienia się poszczególnych sytuacji. W ramach analizy wyników założono, że istotnym kryterium diagnostycznym będzie obecność danego zachowania minimum jeden raz dziennie. Dla każdego z adolescentów objętych badaniem zsumowano występowanie poszczególnych składowych PUI jedynie dla częstotliwości „codziennie lub prawie codziennie”. Ze zgromadzonych wyników można zauważyć, że zdecydowana większość $(82,4 \%)$ nie zadeklarowała nasilenia żadnego z symptomów PUI na najwyższym poziomie. Niespełna co dziesiąty nastolatek posiada jeden symptom PUI występujący w stopniu najwyższym. Dwa symptomy posiada 4,7\% ankietowanych. Skumulowane występowanie PUI zaprezentowano na wykresie 8.1.

Prowadzone dotychczas badania sugerują, że około 3\% nastolatków w Polsce posiada symptomy pełnego fonoholizmu (rodzaju PUI) - dane zebrano wśród 22 tysięcy uczniów przez Fundację Dbam o Mój Zasięg (Dębski, 2016). Zbliżone wyniki, mówiące o tym, że pełnoobjawowe PUI towarzyszyło 0,45\% nastolatków mieszkających na obszarach wiejskich oraz 2,9\% w przestrzeni miejskiej, zostały w 2015 roku zaprezentowane przez lubelski zespół badaczy zachowań ryzykownych w sieci (Pawłowska i in., 2015). Z kolei wyniki badaczy z Krakowa $(\mathrm{N}=680,2017)$ przeprowadzone przy użyciu skróconej wersji testu K. Young ukazują, że zagrożonymi PUI jest 9,8\% młodych 
ankietowanych. Pełne symptomy posiada o wiele mniejszy odsetek respondentów (Solecki, 2018; Mróz, Solecki, 2017). Zebrane dane w ramach badania EU KIDS są w wielu obszarach spójne ze wcześniejszymi analizami dotyczącymi PUI. Natomiast bezpośrednie porównanie wyników jest zagadnieniem niemożliwym do wykonania ze względu na rozbieżności metodologiczne.

Wykres 8.1. Skumulowane występowanie czynników PUI

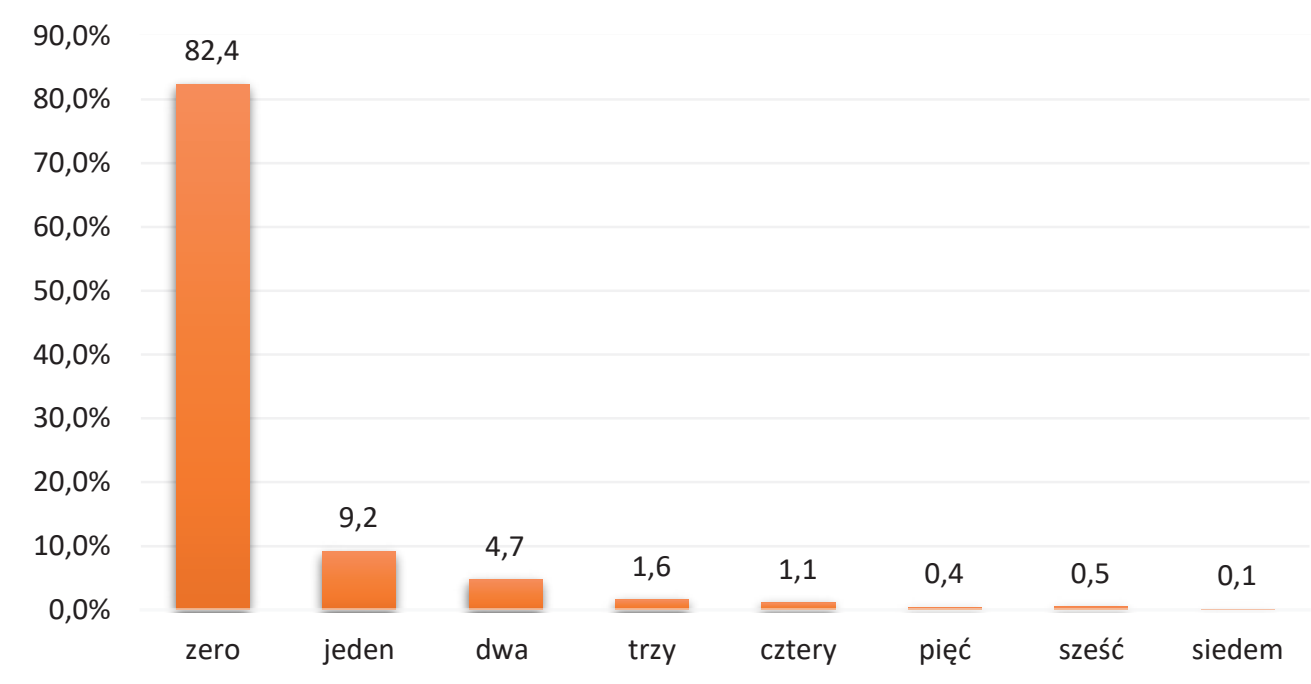

$\mathrm{N}=985-$ młodzież $\mathrm{w}$ wieku 11-17 lat

\section{Ważny fakt}

Wśród nastolatków PUI najczęściej dotyczy występowania jednego z siedmiu czynników. Płeć w większości wymienionych przypadków nie różnicuje PUI, jednakże o wiele częściej, pomimo braku zainteresowania treściami w internecie, tego medium używają dziewczęta $\left(\mathrm{Chi}^{2}=36,28, p<0,0001\right)$, z kolei chłopcy nieco częściej zaniedbują spotkania ze znajomy$\mathrm{mi}$, rodzinę i naukę na rzecz bycia online $\left(\mathrm{Chi}^{2}=21,88, \mathrm{p}<0,01\right)$. W starszych grupach wiekowych PUI jest bardziej dostrzegalne w kontekście braku samokontroli $\left(\right.$ Chi $^{2}=1377,17$, $p<0,0001$. Ponadto starsze grupy również trochę częściej deklarują, że z powodu bycia online spędzają mniej czasu z rodziną i znajomymi (Chi²=1397,88, p<0,0001). 
W zależności od przyjętej perspektywy oraz wykorzystanego narzędzia badawczego czy też grupy wiekowej zmienia się skala zjawiska PUI (Arslan i in., 2015; Tomczyk, Selmanagic-Lizde, 2018; Alt, Boniel-Nissim, 2018). Należy jednocześnie stanowczo zaznaczyć, że brak jednoznacznych i ostrych diagnostycznie wskaźników uniemożliwia miarodajne określenie skali zjawiska PUI (Rębisz i in., 2016). Obecnie coraz częściej w literaturze przedmiotu podkreślane jest znaczenie profilaktyki uprzedzającej, eliminującej wystąpienie PUI. Tego rodzaju podejście zakłada tworzenie alternatyw dla zachowań ryzykownych. Z kolei w sytuacji występowania PUI stosowane są zróżnicowane podejścia terapeutyczne, bazujące głównie na założeniach terapii kognitywno-behawioralnej (Malak, 2018; Penberthy, Wartella, Vaughan, 2010). 



\section{Elektroniczna przemoc rówieśnicza (cyberprzemoc)}

Jacek Pyżalski (Uniwersytet im. Adama Mickiewicza w Poznaniu)

\section{Od bullyingu do cyberbullyingu}

Zjawisko elektronicznej przemocy rówieśniczej (zwanej często cyberprzemocą), jest w naszych czasach nową odsłoną zjawiska tzw. tradycyjnej przemocy rówieśniczej, która była i jest realizowana w inny sposób. Przemoc rówieśnicza jest zjawiskiem dobrze zbadanym i występuje w środowiskach edukacyjnych oraz przejawia się określonymi wrogimi działaniami, które jedni młodzi ludzie stosują przeciwko innym. W światowych badaniach naukowych najczęściej korzysta się z koncepcji bullyingu, której podstawy w latach siedemdziesiątych XX wieku zarysował pionier tej problematyki Dan Olweus. Od tego czasu datuje się współczesne badania dotyczące tego poważnego problemu społecznego (Pyżalski, 2012).

Bullying (nękanie) jest to najbardziej destrukcyjny i dotkliwy dla ofiary rodzaj przemocy rówieśniczej, charakteryzujący się trzema podstawowymi właściwościami (Olweus, 2013):

- regularnością - ta sama ofiara doświadcza ich regularnie przez dłuższy czas,

- nierównowagą sił - sprawca lub sprawcy, dzięki określonym cechom, są znacznie silniejsi od ofiary, która czuje się bezradna, 
- intencjonalnością - sprawcy chcą zaszkodzić ofierze lub mają świadomość, że ich działania spowodują krzywdę.

Analizy empiryczne, prowadzone od czasu pionierskich badań Dana Olweusa, wskazują, iż doświadczanie bullyingu obniża jakość życia i indukuje poważne problemy w obszarze zdrowia psychicznego ofiar. Jako najczęstsze problemy wskazuje się depresję, objawy psychosomatyczne, odczuwanie lęku (Olweus, 2013; Reijntjes i in., 2010; Ttofi i in., 2011; Monks, 2012, Pyżalski, 2012; Raskauskas, 2010; Smith, 2012; Węgrzynowska, 2016; Zych, Ortega-Ruiz, Del-Rey, 2015). Co więcej ofiarami bullyingu są często dzieci słabsze, doświadczające wielu problemów, np. dzieci ze specjalnymi potrzebami edukacyjnymi (Plichta, 2017). Najpoważniejsze przypadki wiktymizacji, często połączone z innymi problemami życiowymi młodego człowieka, wiążą się z podejmowaniem prób samobójczych, czyli najbardziej drastyczną konsekwencją doświadczania przemocy rówieśniczej (Davies, Cunningham, 1999). Charakter i natężenie konsekwencji doświadczania przemocy rówieśniczej są bardzo zróżnicowane i zależne od kompetencji i strategii radzenia sobie stosowanych przez ofiary (Machackova i in., 2013; Raskauskas, Huynh, 2015). Natomiast zaangażowanie w bullying jest skorelowane z problemami zdrowia psychicznego oraz innymi zaburzeniami zachowania sprawców, a także zachowaniami ryzykownymi, które podejmują (Kochenderfer, Ladd, 1996). Warto zauważyć, że problemy dotyczą nie tylko ofiar i sprawców, lecz również świadków (Garandeau, Cillessen, 2006). Oznacza to, że młodzi ludzie, którzy nie są bezpośrednio sprawcami ani ofiarami bullyingu, także odczuwają jego konsekwencje.

Świadkowie mogą przyjmować różne role: być obojętni, wspierać agresorów, aktywnie im się przeciwstawiać lub stawać w obronie ofiary (Salmivalli, 1999; Salmivalli, Karhunen, Lagerspetz, 1996; Salmivalli i in., 1996; Salmivalli, Voeten, Poskiparta, 2011).

Działania podejmowane przez sprawców mogą przyjmować formę agresji fizycznej (wobec ofiary lub należących do niej przedmiotów), werbalnej (słownej) oraz relacyjnej (wykluczenie, nastawianie grupy przeciwko ofierze). Należy zwrócić uwagę, że ten ostatni typ agresji jest często pomijany w działaniach profilaktycznych i interwencyjnych (Jaskulska, Poleszak, 2015; Pyżalski, 2012).Podejmowanie opisanych działań bywa nazywane, jak już wcześniej wspomniano, tradycyjną przemocą rówieśniczą, bazującą na tym, że sprawca bądź sprawcy i ofiara spotykają się twarzą w twarz (Pyżalski, 2012). 
Rok 2003 uznaje się w literaturze dotyczącej bullyingu za przybliżony czas, od którego zaczęto mówić o elektronicznej przemocy rówieśniczej, zwanej powszechnie cyberprzemocą. Charakteryzuję się ona użyciem mediów cyfrowych jako narzędzia realizacji agresji wobec rówieśników (Pyżalski, 2012; Tokunaga, 2010). Większość badań dotyczących przemocy rówieśniczej w sieci bazuje na przywołanej tu koncepcji bullyingu, uznając przemoc za pomocą technologii informacyjno-komunikacyjnych jako jeden z jego elementów.

Istotne pytanie dotyczy tego, czy w przypadku nowego narzędzia realizacji przemocy mamy do czynienia z innym zjawiskiem niż tradycyjny bullying, niosącym odmienne konsekwencje i mechanizmy? Na ile adekwatna będzie też przywołana już wcześniej typologia obejmująca przemoc fizyczną, werbalną i relacyjną? (Olweus, Limber, 2018). W tym kontekście tradycyjne kryteria mogą wiązać się z innymi mechanizmami. Przykładowo przewaga sprawców może wynikać z lepszego opanowania wykorzystania technologii, a powtarzalność nie z tego, że sprawca działa wielokrotnie, lecz z tego, że kompromitujący materiał jest widoczny publicznie online i może być wielokrotnie oglądany przez inne osoby (Pyżalski, 2012).

Warto przyjrzeć się, czy poszczególne tradycyjne typy przemocy rówieśniczej mogą być realizowane elektronicznie. Z jasnych powodów przemoc fizyczna jest niemożliwa do przeprowadzenia za pomocą narzędzi internetowych. Wyjątkiem jest tutaj stosowanie „fizycznych” ataków hakerskich na dane, oprogramowanie lub urządzenia komputerowe ofiary, w wyniku których pojawiają się zniszczenia własności. Można w tym przypadku mówić o pewnej analogii do fizycznego niszczenia przedmiotów należących do ofiary.

Możliwa jest natomiast łatwa do realizacji agresja słowna przez internet. W sieci mamy do czynienia z wykorzystaniem tzw. komunikacji zapośredniczonej przez komputer (computer mediated communication). Daje to bardzo szerokie możliwości realizacji takiej agresji zarówno poprzez wykorzystanie wciąż dominującej w internecie komunikacji tekstowej, jak i przy zastosowaniu komunikacji audio i video. Dotyczy to zarówno komunikatów kierowanych do ofiary bezpośrednio, jak i takich, które są publikowane w różnych miejscach w intrenecie i dostępne szerszej publiczności. W tym kontekście mamy do czynienia ze „starym winem w nowej butelce”. Agresja ma bowiem charakter werbalny. Jednocześnie komunikacja jest zapośredniczona przez medium. To zapośredniczenie (głównie poprzez określone mechanizmy tego typu komunikacji) wnosi, przynajmniej w niektórych przypadkach, nowe aspekty jakościowe. Zostaną one omówione w części poświęconej właśnie tym mechanizmom. 
Ostatnia w tradycyjnej typologii - przemoc relacyjna - może także pojawiać się w środowisku online. Jak wskazują badania, młodzi ludzie w większości przypadków utrzymują kontakt w internecie z osobami znanymi z tradycyjnych grup (np. z zespołów klasowych). Wykluczenie może tu więc polegać na nienawiązywaniu relacji, braku ich podtrzymywania lub ich niskiej jakości, a także manipulowaniu tymi relacjami w taki sposób, by kogoś z nich wykluczyć (Jaskulska, Poleszak, 2015; Pyżalski, 2012).

Na obecnym etapie badań cyberbullying definiowany jest najczęściej jako ciąg aktów agresji celowo i w sposób powtarzalny kierowanych przeciwko innej osobie, która nie może się obronić (doświadcza bezradności w tym zakresie) (Dooley, Pyżalski, Cross, 2009; Pyżalski, 2012; Tokunaga, 2010). Jednocześnie sposób operacjonalizacji tego zjawiska w badaniach jest bardzo zróżnicowany, co nie pozwala zwykle na proste porównywanie wartości wskaźników uzyskanych przez poszczególnych badaczy (Garret, Lord, Young, 2016; Olweus, Limber, 2018).

Ofiary cyberbullyingu doświadczają takich samych konsekwencji w obszarze zdrowia psychicznego, jak ofiary bullyingu (Bauman, 2014; Olenik-Shemesh i in., 2012; Pyżalski, 2012). Co istotne, bardzo trudno jest w badaniach oddzielić efekty cyberbullyingu i tradycyjnego bullyingu, których ofiary często doświadczają równocześnie. Jest tak przede wszystkim dlatego, że właściwie wszystkie wyniki badań potwierdzają nakładanie się zjawiska tradycyjnego i elektronicznego bullyingu. Oznacza to, że ci, którzy są ofiarami twarzą w twarz, są też nimi najczęściej online. Bardzo rzadko ktoś doświadcza przemocy ze strony rówieśników jedynie w internecie. Podobnie prawie wcale nie ma sprawców działających jedynie online - najczęściej uzupełniają oni działaniami w internecie wrogie działania, które podejmują poza nim (Hinduja, Patchin, 2009; Kowalski, Morgan, Limber, 2012; Pyżalski, 2012; Olweus, Limber, 2018).

\section{Mechanizmy psychologiczne wzmacniające elektroniczną przemoc rówieśniczą}

Badacze zajmujący się przemocą rówieśniczą w sieci, a nawet szerzej, agresją za pomocą technologii informacyjno-komunikacyjnych, poszukują informacji na temat mechanizmów psychologicznych, które mogą takiej agresji sprzyjać. Ostatnich dwadzieścia lat badań pozwoliło szereg takich niespecyficznych 
i specyficznych mechanizmów zidentyfikować i potwierdzić ich występowanie empirycznie. Jednym z najczęściej wymienianych w tym kontekście zjawisk jest tzw. rozhamowanie, przejawiające się tym, iż sprawca może podejmować online działania, od których powstrzymałby się twarzą w twarz (Suler, 2004). Mechanizm ten należy wiązać z czterema potencjalnymi właściwościami komunikacji zapośredniczonej, tj. anonimowością, niewidocznością, asynchronicznością i tekstualnością (Joinson, 2009; Lapidot-Lefler, Barak, 2012). Analizując kolejno te właściwości, należy wskazać, iż sprawcy, którzy mają poczucie, że osoba zaatakowana nie może ich zidentyfikować (anonimowość), są niewidoczni dla ofiary oraz komunikują się asynchronicznie, czyli w taki sposób, iż reakcja rozmówcy jest opóźniona. Co więcej często do komunikacji używają wciąż dominującego kanału tekstowego. To wszystko wiąże się z tym, że brak jest, obecnych w procesie komunikacji zapośredniczonej, sygnałów niewerbalnych ze strony ofiary (lub są one bardzo zredukowane). Nie mogą one zatem posłużyć jako mechanizm hamujący działania sprawcy i pobudzić jego mechanizmy empatyczne (Barlińska, Szuster, Winiewski, 2013).

Warto również zwrócić uwagę, że elektroniczna przemoc rówieśnicza często nie jest realizowana anonimowo. Przeczy to obiegowym przekonaniom na temat tego zjawiska. Wyniki badań Juvonen i Gross (2008) na dużej próbie amerykańskich adolescentów wykazały, że około $65 \%$ ofiar cyberprzemocy wiedziało, kto jest agresorem, a połowa znała tych sprawców ze szkoły, do której chodziła. Podobnie wyniki uzyskali Hinduja i Patchin (2009). Tutaj zdecydowana większość ofiar potrafiła wskazać osoby, które ich atakowały (80\%) i właściwie zawsze były znajomymi osobami ze środowiska online. Wyniki dużych polskich badań wskazują, iż jedynie co czwarta ofiara agresji elektronicznej nie wiedziała, kto był wobec nich sprawcą agresji online (Pyżalski, 2012). Badania jakościowe przeprowadzone w naszym kraju pokazują ponadto, że uczniowie - sprawcy cyberbullyingu - często nie podejmują próby ukrycia swojej tożsamości, wysyłając nieprzyjemne informacje ze swojego telefonu lub profilu w portalu społecznościowym. W obydwu przypadkach ofiara nie musi podejmować żadnych specjalnych działań, by zidentyfikować sprawcę.

Kolejny mechanizm, który może czynić agresję online bardziej destrukcyjną niż tradycyjna, to ten związany z ciągłym dostępem sprawców do ofiary (Bauman, 2013; Pyżalski, 2012; Smith, 2010). Większość młodych ludzi funkcjonuje always on (zawsze podłączeni), co w dużym stopniu wiąże się obecnie z powszechnym wykorzystaniem portali społecznościowych (Ito i in., 2008; Maka- 
ruk, 2013). Oznacza to, że sprawca przemocy może w każdej chwili skierować komunikaty do ofiary. Treści te dotrą do niej bez względu na miejsce przebywania. Nie jest tu więc tak, jak było w sytuacji wyłącznie tradycyjnego bullyingu, że młody człowiek miał miejsce (np. własny dom), gdzie był niedostępny dla sprawców i nie doświadczał aktów przemocy. Z wielu powodów młodzi ludzie, którzy doświadczają przemocy w internecie, nie będą mogli zrezygnować z bycia online, gdyż jest ono kluczową potrzebą młodego człowieka w zakresie utrzymywania kontaktów rówieśniczych. Jednak nawet taka decyzja nie chroni przed doświadczaniem przemocy online - sprawcy mogą bowiem rozsyłać i publikować informacje na temat ofiary, a nie kierować komunikatów bezpośrednio do niej.

Chociaż cytowana wyżej definicja bullyingu uwzględnia intencjonalność, to wielu młodych sprawców podejmuje działania zapośredniczone, które przynoszą katastrofalne konsekwencje, mimo że nie planowały skrzywdzenia drugiej osoby. Dzieje się tak zwykle dzięki oddziaływaniu opisanych wyżej mechanizmów, które mocno uaktywniają się w warunkach komunikacji zapośredniczonej. W badaniach polskich nastolatków prawie 40\% respondentów przyznało się, że wysłało przez internet lub telefon komórkowy treść, która miała stanowić żart, a w efekcie wyrządziła krzywdę drugiej osobie (Pyżalski, 2012). Zatem mechanizm bezrefleksyjnego działania sprawców cyberprzemocy rówieśniczej należy uznać za powszechny.

Podsumowując to bardzo skrótowe omówienie mechanizmów cyberprzemocy, warto zwrócić uwagę, że choć mogą one powszechniej występować i silniej działać w przypadku cyberprzemocy, to działają one także w pewnym stopniu w przypadku tradycyjnego bullyingu. Przykładem może być działanie z ukrycia (anonimowe). Chociaż łatwiej można działać anonimowo, korzystając z komunikacji zapośredniczonej, to ukryte działania są także możliwe offline. Dzieje się tak wtedy, gdy jeden uczeń niszczy własność drugiego pod jego nieobecność lub wypisuje na ścianie obraźliwe słowa na jego temat. Możemy tutaj mówić raczej o efekcie skali, a nie kompletnie nowej jakości.

\section{Wyniki badań}

W badaniu Eu Kids Online założono, że respondenci powinni być pytani o przemoc rówieśniczą nie tylko w kontekście działania w sieci, ale w szerszym kontekście o wszystkie sytuacje, w jakich mogą takiej przemocy doświadczać. Zde- 
cydowano zatem, iż zastosowane zostaną pytania definicyjne, tj. takie, gdzie na początku respondenci zapoznają się z definicją zjawiska, którą muszą uwzględniać, odpowiadając na dalsze pytania. Definicja dotycząca agresji rówieśniczej została sformułowana w następujący sposób:

Czasami dzieci i nastolatki mówią lub robią innemu młodemu człowiekowi nieprzyjemne lub złośliwe rzeczy. Bywa, że zdarza się to na przykład wiele razy, w różne dni, przez dłuższy czas. Może to być na przykład:

- drażnienie się z kimś w sposób, który się tej osobie nie podoba

- bicie, kopanie, popychanie

- wykluczenie kogoś ze wspólnych spraw.

Kiedy ktoś robi komuś innemu coś nieprzyjemnego lub złośliwego w ten sposób, może się to zdarzyć:

- twarzą w twarz (osobiście)

- przez telefon komórkowy (rozmowy, SMS-y, MMS-y, filmiki wideo)

- przez internet (e-mail, komunikator, portal społecznościowy, czat).

Warto przeanalizować tę definicję, by dobrze zrozumieć uzyskane w naszych badaniach wyniki. Po pierwsze, badani pytani byli o przemoc rówieśniczą, czyli taką, w której zarówno sprawcami, jaki ofiarami są młodzi ludzie. Po drugie, uwaga respondenta była kierowana nie na incydenty (pojedyncze przypadki agresji), lecz przemoc, która realizowana jest wielokrotnie, przez dłuższy czas. Uwzględniając wyżej przedstawione informacje dotyczące (cyber)bullyingu, możemy uznać, że właśnie o taki rodzaj przemocy rówieśniczej tu chodzi (choć respondent nie ma obowiązku wyłączenia innych doświadczeń, np. pojedynczych incydentów). Badani mieli odnieść się zarówno do agresji tradycyjnej (realizowanej twarzą w twarz), jak i elektronicznej (realizowanej za pomocą telefonu komórkowego, internetu). Należy zwrócić uwagę, iż włączono tu także bardzo istotną i pomijaną w wielu badaniach przemoc relacyjną (wykluczenie ze wspólnych działań).

Wyniki odpowiedzi na pierwsze analizowane pytanie pokazują, jaki odsetek młodych ludzi w ogóle doświadczył przemocy rówieśniczej w ciągu roku poprzedzającego badanie (bez względu na jej typ) (rys. 9.1). 


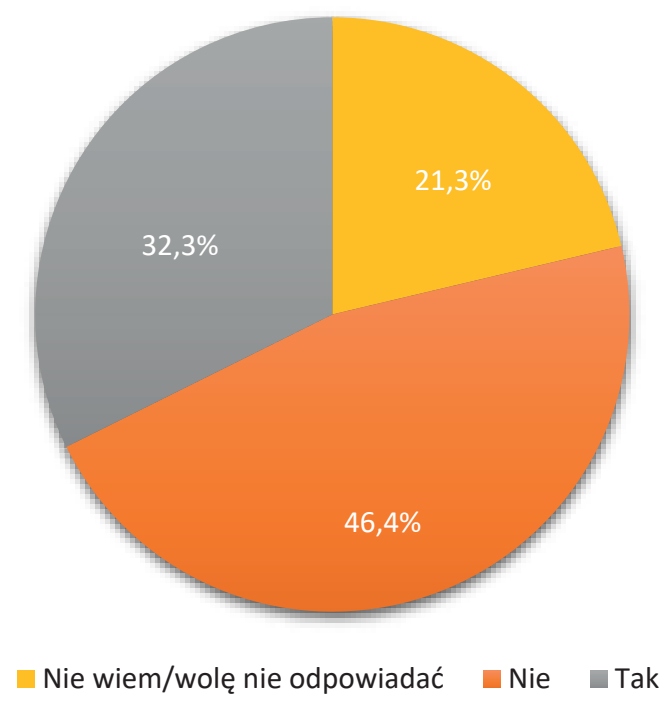

Cała próba $\mathrm{N}=1249$ - 9-17 lat

Okazuje się, że prawie jedna trzecia badanych (404 osoby) doświadczyła w ciągu roku poprzedzającego badanie agresji/przemocy rówieśniczej. Interpretując tę wartość wskaźnika wiktymizacji, musimy pamiętać, że obejmuje ona wszystkie doświadczenia agresji rówieśniczej (twarzą w twarz i online) z długiego czasu (rok poprzedzający badanie). Do tego, choć wprowadzająca definicja kieruje uwage respondenta na doświadczenia regularne i długotrwałe, to polecenie w wyraźny sposób nie wskazuje, by tylko do takich doświadczeń ograniczył się odpowiadając. Zatem respondenci mogli tu zaliczać także mniej poważne sytuacje, których doświadczyli. Warto podkreślić, że wskaźnik nie różni się radykalnie od tych uzyskanych w innych podobnych badaniach (por. Pyżalski, 2012). Co prawda musimy pamiętać, że rzadko badania tego typu prowadzone są za pomocą ujednoliconej metodologii, co często czyni porównania niemożliwymi. Jednocześnie spory odsetek badanych (częściej niż co piąty) wskazuje, iż nie chce odpowiadać na to pytanie lub nie potrafi udzielić odpowiedzi. Trudno przesądzać o przyczynach. Jedną z nich może być drażliwość kwestii poruszonych w tym pytaniu - dotyczy ono bowiem trudnych doświadczeń, które wiążą się z silnymi negatywnymi emocjami. Gdyby 
tak było, rzeczywisty wskaźnik doświadczania agresji rówieśniczej mógłby być wyższy.

Kolejna kwestia dotyczyła doświadczania tradycyjnej przemocy rówieśniczej, w której sprawca nie wykorzystuje technologii informacyjno-komunikacyjnych do jej realizacji.

Wykres 9.2. Częstotliwość doświadczania tradycyjnej przemocy rówieśniczej (offline)

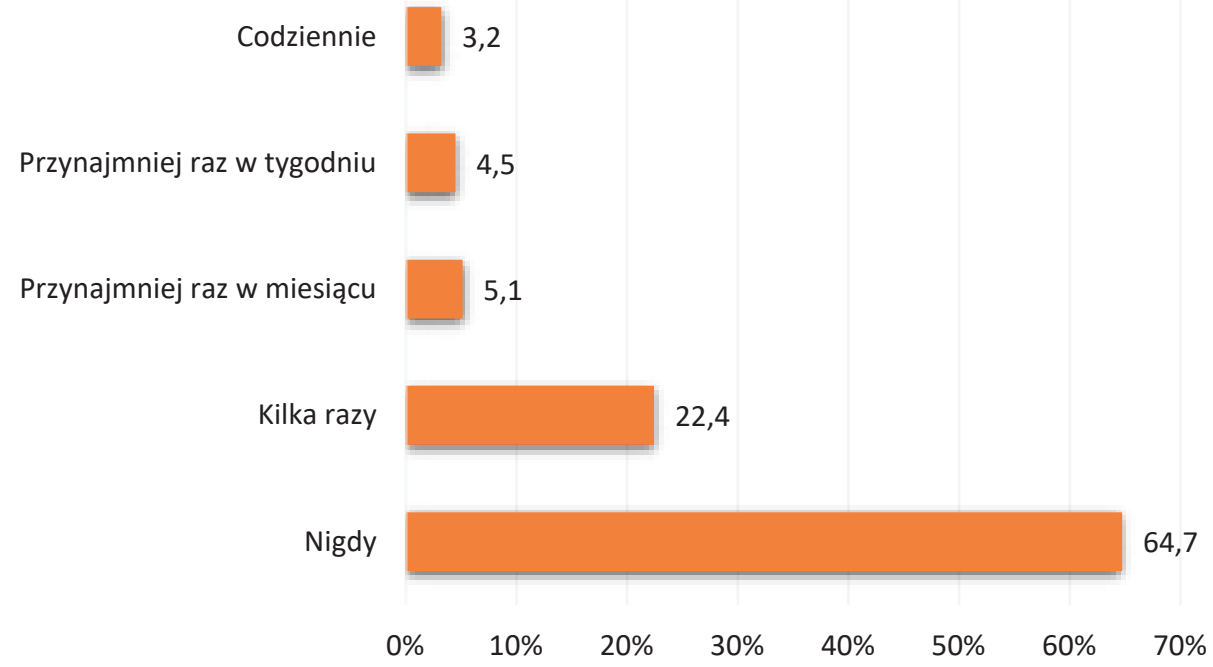

N=349 - młodzi ludzie w wieku 9-17 lat, którzy byli ofiarami agresji rówieśniczej (wyłączono odpowiadających „nie wiem" $\mathrm{i}$,trudno powiedzieć")

Należy zauważyć, że agresji tradycyjnej doświadczyła ponad 1/3 badanych, którzy wskazują, że byli ofiarami agresji rówieśniczej. W przypadku co piątej ofiary takiej agresji były to pojedyncze przypadki (kilka razy w ciągu roku). Bardzo nasilona wiktymizacja (przynajmniej raz w tygodniu lub częściej) dotyczy około $8 \%$ badanych. Ten wskaźnik należy, jednak z dużą ostrożnością, traktować jako wskaźnik rozpowszechnienia tradycyjnego bullyingu rówieśniczego (wykres 9.2). Ostrożność ta powinna wynikać z tego, że nie uwzględniono w obecnych badaniach dwóch pozostałych (obok regularności) charakterystyk bullyingu, tj. nierównowagi sił i intencjonalności.

Natomiast w kontekście całej populacji (wszyscy badani) odsetek ofiar to około $6,4 \%$. 
Wykres 9.3. Doświadczanie agresji rówieśniczej przez internet/telefon (online)

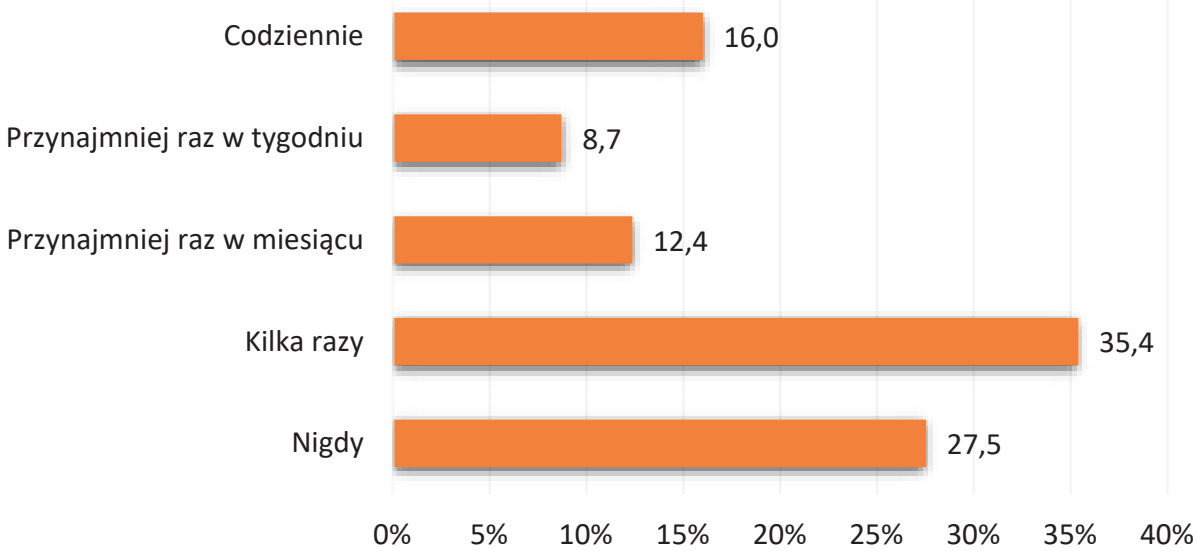

N=356 - młodzi ludzie w wieku 9-17 lat, którzy byli ofiarami agresji rówieśniczej (wyłączono odpowiadających „nie wiem" i „trudno powiedzieć”)

Uwagę zwraca dużo wyższa częstotliwość doświadczania agresji rówieśniczej online w porównaniu z wcześniej przedstawionymi wynikami dotyczącymi tradycyjnej agresji rówieśniczej (wykres 9.3). Jest ona dominującym typem agresji doświadczanej przez młodych ludzi. Wśród tych, którzy byli ofiarami jakiejkolwiek agresji rówieśniczej było jedynie 27,5\% takich, którzy nie doświadczyli tego typu agresji w ciągu 12 miesięcy przed badaniem (wykres 9.3). Natomiast prawie 1/4 respondentów z tej grupy była ofiarą agresji online raz w tygodniu lub częściej. Pamiętajmy jednak, że nie dysponujemy tutaj danymi dotyczącymi powagi tych aktów agresji. Podobnie jak w przypadku przemocy tradycyjnej, wskaźnik raz w tygodniu lub można już przyjąć za rozpowszechnienie cyberbullyingu. Trzeba jednak pamiętać, że omówione tu odsetki odnoszą się do populacji tych, którzy doświadczyli agresji rówieśniczej.W całej populacji częsta wiktymizacja w zakresie elektronicznej przemocy rówieśniczej dotyczyła 7,1\% młodych ludzi w wieku 9-17 lat.

\section{Współwystępowanie wiktymizacji agresji tradycyjnej i elektronicznej}

W badaniach sprawdziliśmy, czy doświadczanie tradycyjnej agresji rówieśniczej jest powiązane z doświadczaniem agresji elektronicznej (tabela 9.1). Okazuje się, że statystyczny związek istnieje $\mathrm{i}$ jest on silny $\left(\mathrm{Chi}^{2}=125,8, \mathrm{p}<0,00001\right.$, 
R Spearmana=0,55, p<0,00001). Im częściej młodzi ludzie doświadczali agresji tradycyjnej ze strony rówieśników, tym częściej byli także ofiarami rówieśniczej agresji elektronicznej.

Tabela 9.1. Wiktymizacja rówieśnicza tradycyjna a wiktymizacja online

\begin{tabular}{|l|c|c|c|c|}
\hline $\begin{array}{c}\text { Doświadczanie rówieśniczej } \\
\text { agresji twarzą w twarz } \\
\text { (tradycyjnej) }\end{array}$ & $\%$ & $\begin{array}{c}\text { nigdy lub } \\
\text { kilka razy }\end{array}$ & w miesiącu & raz w tygodniu \\
lub częściej
\end{tabular}

N=342 Respondenci w wieku 9-17 lat, którzy określili częstotliwość doświadczania agresji rówieśniczej offline i online; $\mathrm{Chi}^{2}=125,8, \mathrm{p}<0,00001, \mathrm{R}$ Spearmana $=0,55, \mathrm{p}<0,00001$

Ponad $80 \%$ badanych, którzy nigdy lub jedynie kilka razy byli ofiarami agresji tradycyjnej równie rzadko doświadczyło agresji elektronicznej. Jednak kiedy ktoś doświadczał sporo agresji twarzą w twarz, był także częściej ofiarą agresji online. Aż 62,5\% uczniów doświadczających agresji raz w tygodniu bądź częściej, była jej ofiarą tak samo często elektronicznie.

\section{Ważny fakt}

Bardzo rzadko jest tak, że młody człowiek jest jedynie ofiarą agresji w internecie. Bycie ofiarą online przeważnie dotyczy tych, którzy doświadczają przemocy rówieśniczej twarzą w twarz.

\section{Doświadczenie różnych technicznych przejawów rówieśniczej agresji elektronicznej}

Ze względu na to, że agresja rówieśnicza realizowana w różny sposób posiada różny potencjał wiktymizacyjny (krzywdzący) zdecydowano się zapytać osoby, które jej doświadczyły, o wybrane przykłady tego, co konkretnie zrobił sprawca (tabela 9.2). Badani najczęściej otrzymywali nieprzyjemne lub złośliwe materiały w komunikacji indywidualnej (8,7\%). Na drugim miejscu znalazła się agresja relacyjna 
- wykluczenie z grupy online - jej ofiarą był co dwudziesty respondent. Podobny odsetek badanych doświadczył agresji, kiedy sprawca lub sprawcy grozili im bądź umieszczali informacje na ich temat w publicznej przestrzeni internetu. Wiązało się to z dostępem do takich materiałów szerszego grona odbiorców. Dużo rzadsze (2\%) było zmuszanie do zrobienia online czegoś, czego sprawca nie chciał.

Tabela 9.2. Doświadczanie różnych przejawów agresji rówieśniczej w roku poprzedzającym badanie

\begin{tabular}{|c|c|c|}
\hline Przejawy agresji elektronicznej & $\%$ & $\begin{array}{l}\text { Różnice między grupami wiekowymi } \\
\qquad 9-10 \text { lat i } 12-17 \text { lat }\end{array}$ \\
\hline $\begin{array}{l}\text { Przesyłano mi nieprzyjemne albo złośliwe } \\
\text { wiadomości (np. słowa, obrazki, zdjęcia lub filmiki) }\end{array}$ & 8,7 & Starsi częściej * \\
\hline $\begin{array}{l}\text { Zostałem/am odsunięty/a albo wykluczony/a } \\
\text { z grupy lub z robienia czegoś w internecie }\end{array}$ & 5,5 & Brak istotnych różnic \\
\hline $\begin{array}{l}\text { Przydarzyły mi się inne nieprzyjemne rzeczy } \\
\text { w internecie }\end{array}$ & 5,0 & Starsi częściej* \\
\hline $\begin{array}{l}\text { Ktoś rozsyłał lub zamieszczał gdzieś nieprzyjemne } \\
\text { lub złośliwe wiadomości na mój temat (np. słowa, } \\
\text { obrazki, zdjęcia lub filmiki) w taki sposób, że inni } \\
\text { mogli je zobaczyć }\end{array}$ & 4,9 & Starsi częściej* \\
\hline Ktoś mi groził w internecie & 4,9 & Brak istotnych różnic \\
\hline $\begin{array}{l}\text { Zmuszono mnie do zrobienia czegoś, czego nie } \\
\text { chciałem/am }\end{array}$ & 2,0 & Brak istotnych różnic \\
\hline
\end{tabular}

N=1249 - cała próba 9-17 lat

\section{Ważny fakt}

Wśród tych, którzy doświadczyli agresji w internecie i wypowiedzieli się na temat konkretnych sposobów jej realizacji (było to zależenie od rodzaju agresji - od 221 do 233 osób) stwierdzono kilka zależności ze zmiennymi społeczno-demograficznymi. Starsi uczniowie częściej doświadczali agresji w kontakcie indywidualnym (przesyłanie nieprzyjemnych i złośliwych wiadomości) (Chi² $=3,61$, $p<0,05)$, jak również w publicznej przestrzeni, dostępnej dla szerszego grona odbiorców $\left(\mathrm{Chi}^{2}=3,92\right.$, $p<0,05)$. Przedstawiciele tej grupy wiekowej częściej doświadczali także innych niesprecyzowanych w narzędziu nieprzyjemnych zdarzeń związanych z agresją online $\left(\mathrm{Chi}^{2}=4,15, \mathrm{p}<0,05\right)$.

W żadnym z przejawów agresji nie stwierdzono istotnych różnic między chłopcami i dziewczętami. 


\section{Sprawstwo agresji rówieśniczej}

Analogicznie jak w przypadku pytania o wiktymizację respondenci odpowiadali, czy w końcu roku poprzedzającego badanie byli sprawcami agresji/przemocy rówieśniczej, bez względu na to, czy agresja ta była realizowana tradycyjnie, czy elektronicznie.

Wykres 9.4. Sprawstwo agresji rówieśniczej w ciągu roku poprzedzającego badanie

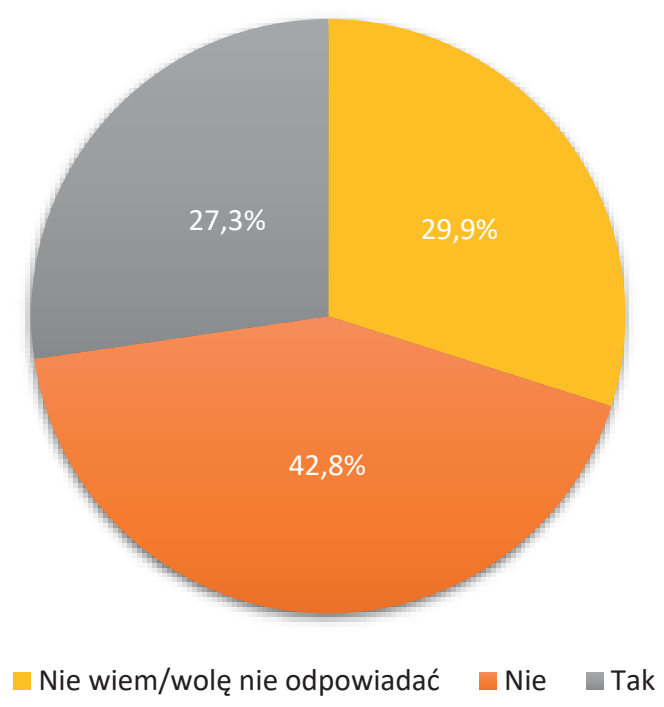

Cała próba $\mathrm{N}=1249$, 9-17 lat

Nieco ponad 27\% (341 osób) respondentów wskazało, że było sprawcami agresji/przemocy wobec rówieśników. Interpretując ten wskaźnik, należy uwzględnić te same zastrzeżenia, które przywołano w przypadku wiktymizacji. Przede wszystkim wśród sprawców byli zarówno ci, którzy dokonali poważnych aktów przemocy, jak i ci, którzy mogli wskazać pojedyncze incydenty. Ponadto wysoki wskaźnik odmów odpowiedzi i odpowiedzi nie wiem, może oznaczać zaniżenie rzeczywistej skali sprawstwa. Tych, którzy wskazali, że byli sprawcami, pytano, jak często dokonywali agresji tradycyjnej (offline). Okazuje się, że w ten typ agresji angażowało się około $75 \%$ badanych (wykres 9.5). Jednocześnie 
częste sprawstwo agresji rówieśniczej, które z ostrożnością traktujemy jako wskaźnik sprawstwa bullyingu, dotyczy około 18,5\% tych, którzy byli sprawcami agresji tradycyjnej.

Wykres 9.5. Częstotliwość zaangażowania w tradycyjne sprawstwo agresji rówieśniczej (offline)

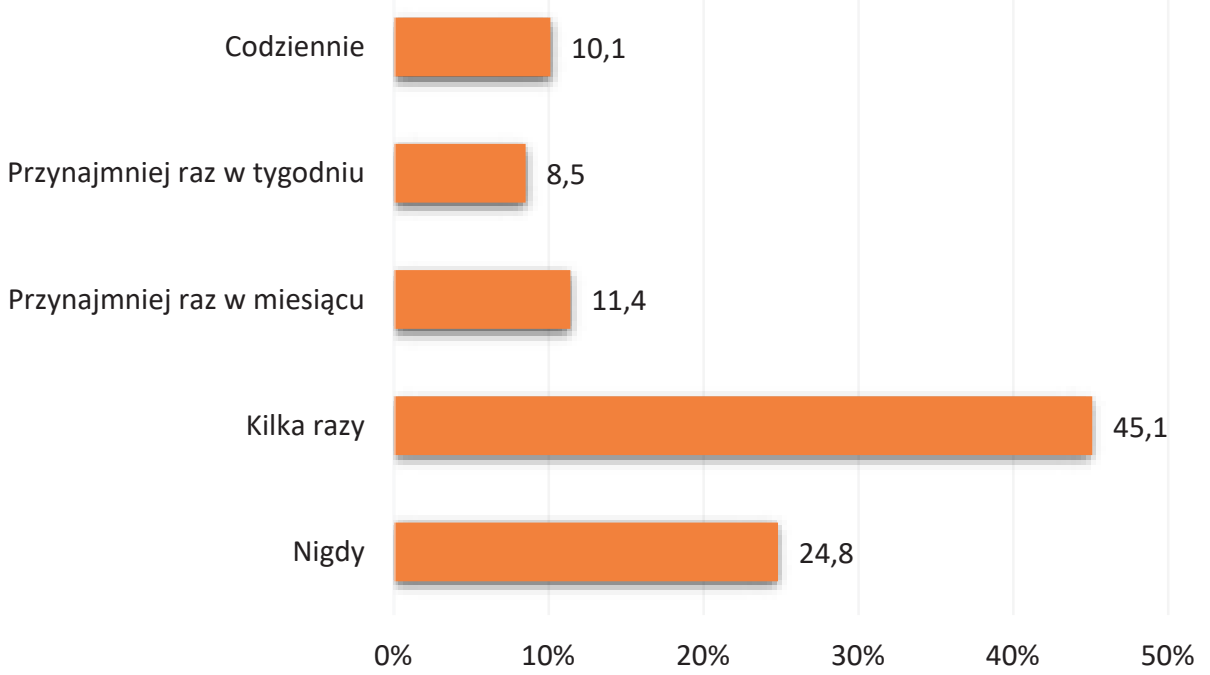

N=306 - młodzi ludzie w wieku 9-17 lat, którzy byli ofiarami agresji rówieśniczej

Z przeprowadzonych badań wynika, że w tradycyjną przemoc rówieśniczą, w odniesieniu do całej populacji, angażuje się 4,6\% respondentów.

Podobne analizy dotyczą przemocy online (wykres 9.6). Inaczej niż w przypadku wiktymizacji, widoczny jest tu brak istotnych różnic pomiędzy wskaźnikami sprawstwa elektronicznego i tradycyjnego. Odsetek badanych, którzy stosują przemoc tradycyjną i elektroniczną jest podobny. W częste sprawstwo (raz w tygodniu lub częściej) angażuje się co piąty młody człowiek spośród tych, którzy przyznali się do bycia agresorem. Taki jest właśnie wskaźnik sprawstwa cyberbullyingu w tej podgrupie. Jednocześnie należy wskazać, że w całej próbie takich sprawców było 5,1\%. 
Wykres 9.6. Częstotliwość zaangażowania w sprawstwo elektronicznej agresji rówieśniczej (online)

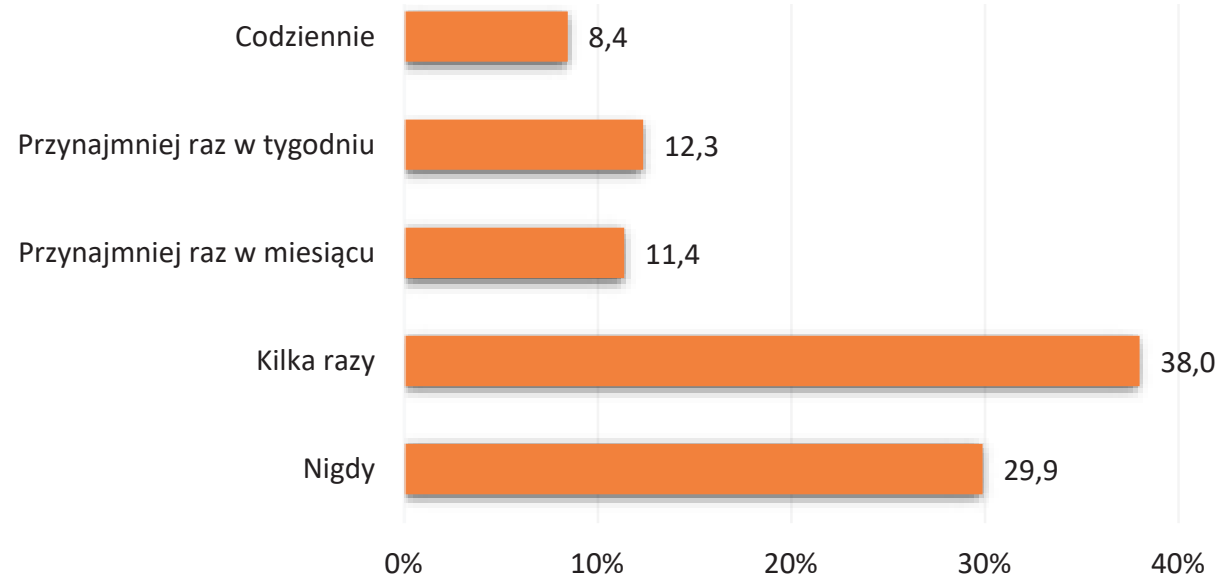

N=308 - młodzi ludzie w wieku 9-17 lat, którzy byli sprawcami agresji rówieśniczej

\section{Współwystępowanie sprawstwa tradycyjnego i elektronicznego}

W badaniu sprawstwa, podobnie jak w przypadku wiktymizacji, sprawdzono także, w jakim stopniu sprawstwo współwystępuje w kontekście offline i online. Uzyskane wyniki potwierdzają silny związek bycia sprawcą w obydwu kontekstach $\left(\mathrm{Chi}^{2}=153,6 ; p<0,00001\right.$, R Spearmana $\left.=0,56, p<0,00001\right)$.

Tabela 9.3. Sprawstwo tradycyjnej agresji rówieśniczej a sprawstwo agresji online

\begin{tabular}{|c|c|c|c|c|}
\hline \multirow{2}{*}{$\begin{array}{c}\text { Sprawstwo tradycyjnej agresji } \\
\text { rówieśniczej }\end{array}$} & \multirow[b]{2}{*}{$\%$} & \multicolumn{3}{|c|}{ Sprawstwo cyberagresji rówieśniczej } \\
\hline & & $\begin{array}{c}\text { nigdy } \\
\text { lub kilka razy }\end{array}$ & $\begin{array}{c}\text { raz } \\
\text { w miesiącu }\end{array}$ & $\begin{array}{l}\text { raz w tygodniu } \\
\text { lub częściej }\end{array}$ \\
\hline nigdy lub kilka razy & $\%$ & 87,2 & 7,3 & 5,5 \\
\hline raz w miesiącu & $\%$ & 45,0 & 30,0 & 25,0 \\
\hline raz w tygodniu lub częściej & $\%$ & 26,8 & 5,6 & 67,6 \\
\hline
\end{tabular}

$\mathrm{N}=306$, Respondenci w wieku 9-17 lat, którzy określili częstotliwość doświadczania agresji rówieśniczej offline i online; $\mathrm{Chi}^{2}=153,6 ; \mathrm{p}<0,00001, \mathrm{R}$ Spearmana $=0,56, \mathrm{p}<0,00001$ 
Prawie w dziewięciu na dziesięć przypadków młodzi ludzie, którzy nie byli lub byli bardzo rzadko sprawcami tradycyjnej agresji, nie podejmowali jej lub podejmowali ją bardzo rzadko online. Z kolei prawie 68\% częstych sprawców przemocy tradycyjnej równie często angażowało się w przemoc elektroniczną.

\section{Ważny fakt}

Bycie sprawcą agresji rówieśniczej w sieci jest bardzo silnie powiązane z byciem sprawcą w kontekście offline. Ci, którzy często atakują rówieśników twarzą w twarz, zwykle robią to też często w internecie.

\section{Omówienie wyników i wnioski}

Wartości wskaźników sprawstwa i wiktymizacji zarówno tradycyjnej, jak i elektronicznej agresji pokazują, że wbrew dosyć często słyszanym opiniom o ich znacznym rozpowszechnieniu, szczególnie w internecie, dotyczą one znaczącej mniejszości populacji młodych ludzi.

Wskaźniki te tylko nieco odbiegają od danych uzyskanych w poprzedniej edycji badań EU Kids Online (Lobe i in., 2011). Wyższy jest ogólny wskaźnik doświadczania agresji (łącznie online i offline), który w badaniach z 2010 roku wynosił w Polsce 19\% (taka sama była średnia europejska), a obecnie wynosi około $32 \%$. Kiedy jednak spojrzymy na wyniki dotyczące doświadczania bullyingu i cyberbullyingu (rozumianego jako doświadczenie wiktymizacji raz w tygodniu lub częściej) to różnice nie są istotne. Wskaźnik bycia ofiarą cyberbullyingu wynosił w 2010 roku ok. 6\%, a obecnie wynosi 7,1\%. Uwzględniając fakt, że w 2010 roku nie badano siedemnastolatków, a pytania dotyczące tej kwestii zadawane były w nieco inny sposób, należy uznać zaobserwowaną zmianę za nieznaczącą.

Bullying i cyberbullying okazały się być zjawiskami silnie powiązanymi. Rzadko agresywni są wobec rówieśników w internecie ci, którzy nie są agresywni poza siecią. Niewielu jest także młodych ludzi, którzy są ofiarami jedynie online. Wynik taki stanowi potwierdzenie wcześniejszych rezultatów badań realizowa- 
nych w Polsce i na świecie (por. Olweus, Limber, 2018; Pyżalski, 2012). Wskazuje też, że nie można w działaniach profilaktycznych traktować cyberprzemocy jako odrębnego zjawiska, które widoczne jest jedynie w kontekście internetu.

Z pewnością należy poszukiwać rozwiązań w zakresie profilaktyki cyberprzemocy rówieśniczej. Jak wskazują jednak wyniki obecnego badania oraz wcześniejszych analiz (por. Gaffney i in., 2018; Pyżalski, 2012; Zych, Ortega-Ruiz, del Rey, 2015) rozwiązania te powinny:

1. Być zintegrowane z holistycznymi programami, obejmującymi także przemoc tradycyjną. Zajmowanie się samą przemocą elektroniczną nie ma uzasadnienia, gdyż w większości przypadków młodzi ludzie, których ona dotyczy, są ofiarami i sprawcami tradycyjnej agresji/przemocy rówieśniczej. Wiele rozwiązań profilaktycznych ma charakter uniwersalny i przekładają się one na redukcję obu rodzajów agresji/przemocy rówieśniczej (por. Pyżalski, 2018).

2. Wykraczać poza proste zajęcia edukacyjne. Muszą one bardziej koncentrować się na uczeniu umiejętności z uwzględnieniem specyfiki komunikacji zapośredniczonej i relacji przejawiających się online.

3. Obejmować także elementy salutogenne - czyli nie tylko tematykę przemocy, ale także kwestie związane z pozytywnym (także prospołecznym) wykorzystaniem sieci.

Przykładem przygotowanego zgodnie z tymi założeniami programu przeciwdziałania cyberprzemocy o ustalonej skuteczności jest Interdyscyplinarny Model Przeciwdziałania Agresji i Cyberprzemocy Technologicznej (IMPACT) ${ }^{1}$.

1 Projekt finansowany w ramach Innowacji Społczenych (IS-2/31/NCBR/2015), w którym partnerami byli: Fundacja Praesterno, Fundacja Dajemy Dzieciom Siłę, Instytut Medycyny Pracy w Łodzi, Politechnika Warszawska i Uniwersytet Warszawski. 



\section{Mowa nienawiści w internecie}

Łukasz Tomczyk (Uniwersytet Pedagogiczny im. Komisji Edukacji Narodowej w Krakowie)

Wiele niekorzystnych zjawisk występujących online jest powiązanych z ich odpowiednikami offline. Przykładem może być relacja pomiędzy byciem sprawcą lub ofiarą agresji w bezpośrednim kontakcie oraz agresji elektronicznej czy też cyberprzemocy. O zależności między zjawiskami związanymi z przemocą wielokrotnie wspomina w swoich publikacjach J. Pyżalski, który podkreśla nakładanie się zjawisk ze świata online i offline. Internet może być środowiskiem sprzyjającym agresji i przemocy elektronicznej ze względu na kilka specyficznych dla mediów cyfrowych cech, takich jak: złudne poczucie anonimowości, niejawność komunikacji online, występowanie niewidzialnej publiczności, efekt kabiny pilota (brak widoczności bezpośrednich skutków agresji i przemocy zapośredniczonej elektronicznie, np. stanów emocjonalnych) (Pyżalski, 2012). Biorąc pod uwagę czynniki wymienione przez badaczy zjawisk związanych z cyberprzemocą i agresją elektroniczną, należy odnieść się do równie istotnego czynnika, jakim jest postrzeganie i ocena przemocy. W tabeli nr 10.1 zaprezentowano procentowy rozkład odpowiedzi odnoszących się do skali akceptacji sytuacji związanych z przemocą. Zakładając, że zachowania ryzykowne w świecie online współwystępują z sytuacjami w przestrzeni offline, należy mieć szczególnie na względzie skalę akceptacji przemocy. 
Tabela 10.1. Jak bardzo zgadzasz się albo nie zgadzasz z poniższymi stwierdzeniami? ZAZNACZ WŁAŚCI-

\section{WA ODPOWIEDŹ W KAŻDYM WIERSZU}

\section{Sytuacje związane} z przemoca

\begin{tabular}{c|c} 
Zdecydowa- & Raczej się \\
nie się nie & nie zgadzam \\
zgadzam & $\%$ \\
$\%$ & $\%$
\end{tabular}

\begin{tabular}{c|c}
\hline Ani się zga- & Raczej się \\
\hline dzam ani nie & zgadzam \\
zgadzam & $\%$ \\
$\%$ &
\end{tabular}

Zdecydowanie się zgadzam

$\%$
13,2 przemocy w stosunku do kogoś, kto pierwszy użył jej wobec Ciebie

\begin{tabular}{|l|l|l|l|l|l|}
\hline 38,0 & 13,2 & 7,9 & 7,1 & 4,7 & 29,1 \\
\hline
\end{tabular}

b) To w porządku użyć przemocy wobec kogoś, kto obraża Twoją rodzinę lub przyjaciół

\section{2,3}

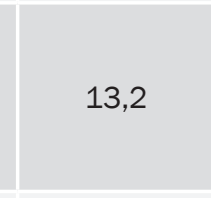

11,6

6,6

6,2

Nie wiem+ Trudno powiedzieć $\%$

c) To w porządku używać przemocy, gdyż to 53,5

8,4

3,5

2,5

3,5

28,5 sprawia przyjemność

d) To w porządku używać przemocy, gdyż wtedy ludzie będą Cię szano53,4 8,5

4,6
wać

e) To w porządku używać przemocy, gdy ktoś śmieje się bądź obraża Cię z powodu 42,3 11,7 8,1 4,4 religii, pochodzenia lub koloru skóry

f) To w porządku używać przemocy, żeby rozwiązywać problemy świata

g) To w porządku, żeby dokonywać aktów terroryzmu

56,6

6,4

2,5

2,1

3,3

29,0

h) To w porządku używać bomb, żeby walczyć z niesprawiedliwością

\section{4,4} 6,9 
Zdecydowane wyrażenie zgody na przemoc, bez względu na przyczynę, nie przekracza 6,2\%. Najczęściej akceptacja przemocy dotyczy sytuacji, w której działanie odnosi się bezpośrednio do danej osoby - np. obrazów najbliższych osób lub do sytuacji odwetowej. Ponad połowa z badanej grupy zdecydowanie potępia przemoc jako narzędzie terroru, rozwiązywania problemów czy też jako sposób na walkę z niesprawiedliwością. Interesujący jest fakt, że niemalże 1/3 ankietowanych nie ma zdania w tym temacie lub nie chce wyrazić opinii. Chłopcy deklarują o wiele częściej przyzwolenie na przemoc dotykającą osobiście samych respondentów lub najbliższych z ich otoczenia. Ponadto chłopcy gotowi są podejmować działania agresywne w sytuacji odwetowej, powiązane z: obroną bliskich osób, czy też poczuciem dyshonoru wynikającym z obrazy uczuć religijnych, pochodzenia lub koloru skóry. Z kolei dziewczęta o wiele częściej deklarują przyzwolenie na przemoc, która sprawia przyjemność. Zastanawiająca jest również kwestia wysokiego odsetka respondentów, którzy nie chcą jednoznacznie wyrazić zdania na temat przyzwolenia wobec sytuacji związanych z przemocą.

\section{Ważny fakt}

Istnieją istotne statystycznie różnice wynikające z płci. Chłopcy o wiele częściej akceptują przemoc jako reakcję na sytuacje dotykające ich samych lub bliskich osób oraz będące następstwem obrazy bliskich osób, religii, pochodzenia, koloru skóry. Z kolei dziewczęta częściej wyrażają przyzwolenie na przemoc, w której uzyskują gratyfikację w postaci przyjemności (odpowiedź - to w porządku używać przemocy, gdyż to sprawia przyjemność).

Wyniki badań Krajowego Biura Przeciwdziałania Narkomanii sugerują, że około $6 \%$ uczniów w polskich szkołach doświadczyło przemocy fizycznej poprzez uderzenie lub pobicie, 4\% spotkało się z sytuacją wymuszenia pieniędzy lub wymuszenia fundowania papierosów lub alkoholu, natomiast $2 \%$ spotkało się z sytuacją kradzieży pieniędzy, ewentualnie cennych rzeczy (Kalka, 2016). Z najnowszych wyników badań przeprowadzonych na zlecenie „Rzecznika Praw Dziecka w 2018 roku wynika, że „społeczna aprobata dla bicia/uderzania dziecka jest nadal niepokojąco wysoka. Aż 43\% badanych akceptuje tzw. klapsy, a blisko jedna czwarta badanych uważa, że lanie jeszcze nikomu nie zaszkodziło" (Jarosz, 2018). Wspomniane wyniki badań 
ukazują wysoki współczynnik przyzwolenia społecznego na przemoc warunkowaną okolicznościami. Akceptacja tego typu zachowań modelowana jest w pierwszej kolejności w środowisku rodzinnym, a następnie rówieśniczym. Zestawiając wyniki EU KIDS Online oraz dane dotyczące przemocy i agresji, których podmiotami stają się dzieci i nastolatki, stwierdzić należy, że obszar ten wymaga szczególnej troski, przede wszystkim poprzez działania profilaktyki selektywnej i uprzedzającej ukierunkowanej na młodzież.

\section{Ekspozycja na mowę nienawiści w internecie}

Mowa nienawiści jest obraźliwym rodzajem komunikacji, który wyraża ideologię nienawiści za pomocą stereotypów. Koncentruje się ona na różnych cechach specyficznych, takich jak: płeć, religia, wiek, przynależność polityczna, rasa lub niepełnosprawność (Chetty, Alathur, 2018). Mowa nienawiści może być w pewnych okolicznościach utożsamiana z pojęciem hejtingu. Szerzenie nienawiści poprzez strony i aplikacje internetowe podlega pod jurysydykcję prawną, w szczegolności gdy związane jest z naruszeniem godności lub namawianiem do popełnienia przestępstwa przeciwko danej osobie lub grupie. Analizując mowę nienawiści, należy wyraźnie podkreślić, że zjawisko to podlega sankcjom karnym. Kwestie zaklasyfikowania wypowiedzi jako podlegające obostrzeniom prawnym regulują art. 256 Kodeksu karnego: „Kto publicznie propaguje faszystowski lub inny totalitarny ustrój państwa lub nawołuje do nienawiści na tle różnic narodowościowych, etnicznych, rasowych, wyznaniowych albo ze względu na bezwyznaniowość, podlega grzywnie, karze ograniczenia wolności albo pozbawienia wolności do lat dwóch" oraz art. 257 Kodeksu karnego: „Kto publicznie znieważa grupę ludności albo poszczególną osobę z powodu jej przynależności narodowej, etnicznej, rasowej, wyznaniowej albo z powodu jej bezwyznaniowości lub z takich powodów narusza nietykalność cielesną innej osoby, podlega karze pozbawienia wolności do lat 3". Mowa nienawiści może być również powiązana ze zniesławieniem czy też znieważeniem definiowanym w artykułach 212 i 216 Kodeksu karnego. Uściślając, nie wszystkie wypowiedzi o negatywnym charakterze spełniają definicję zawartą w wymienionych artykułach Kodeksu karnego. Na wykresie 12.1 zaprezentowano rozkład odpowiedzi dotyczących ekspozycji na mowę nienawiści wśród młodych osób. 
Wykres 10.1. Czy w ciągu OSTATNIEGO ROKU widziałeś/aś w internecie CHOĆ RAZ nienawistne lub poniżające treści albo komentarze skierowane przeciwko określonym ludziom lub grupom ludzi (np. przeciw muzułmanom, imigrantom, Żydom, Romom)?

Nie wiem + nie chcę odpowiadać

$\mathrm{Nie}$

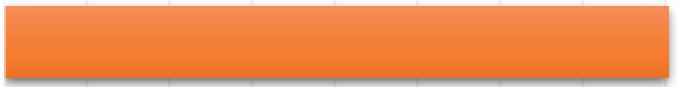

Tak

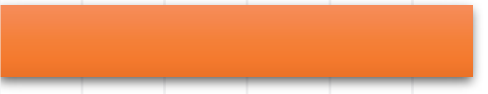

$28,6 \%$

$40,2 \%$

$\mathrm{N}=996-$ młodzież w przedziale 11-17 lat

W ciągu ostatniego roku niemalże co trzeci nastolatek spotkał się w internecie z treściami nienawistnymi lub poniżającymi, albo komentarzami skierowanymi przeciwko określonym ludziom lub grupom ludzi (np. przeciw muzułmanom, imigrantom, Żydom, Romom). Nie istnieje istotna różnica ze względu na wiek czy płeć w dostrzegalności mowy nienawiści.

\section{Ważny fakt}

Niemalże co trzeci nastolatek objęty badaniem spotkał się w ostatnim roku w internecie z mową nienawiści.

Z raportu Global Dignity ( $\mathrm{N}=600$ ) wynika, że niespełna 1/3 adolescentów minimum jeden raz dziennie sprawdzała opinie innych, pojawiające się pod wpisami internetowymi. Pod wpływem ich sugestii $14 \%$ było w stanie zmienić własne zdanie. Sytuacja ta dotyczy również zmiany zdania w ramach ekspozycji na mowę nienawiści. Dodatkowo warto podkreślić, że 2/3 ankietowanych adolescentów zmieniło opinie, sugerując się negatywnymi komentarzami w internecie. Co dziesiąty przyznaje, że bycie hejterem sprawiło mu przyjemność - było formą specyficznej rozrywki (Global Dignity, 2016). Akceptacja mowy nienawiści jest procesem społecznym. Wraz z brakiem reakcji na negatywne komentarze pojawiające się w mediach tradycyjnych lub cyfrowych rośnie przyzwolenie na taką formę wyrażania opinii (Bilewicz, i in., 2017). Dlatego też, uwzględniając wyni- 
ki przedstawione na wykresie 10.1 ukazujące powszechność zjawiska, konieczne jest włączenie w programy profilaktyki medialnej treści dotyczących klasyfikowania komunikatów medialnych będących mową nienawiści oraz umiejętności reagowania na treści destruktywne w konstruktywny sposób.

\section{Częstotliwość narażenia na mowę nienawiści}

Komunikaty o charakterze nienawistnym najczęściej spotykane są na popularnych stronach www, a więc: portalach społecznościowych, forach internetowych, blogach, dyskusjach prowadzonych pod artykułami w serwisach informacyjnych. Poniżej zaprezentowano wypowiedzi obrazujące częstotliwość narażenia na treści „hejterskie” w ostatnim roku. Dane dotyczą 311 młodych osób (31,2\%), które zadeklarowały, że spotkały się z tego typu treściami w przeciągu ostatniego roku.

Wykres 10.2. Jak często w ciągu OSTATNIEGO ROKU widziałeś/aś w internecie CHOĆ RAZ nienawistne lub poniżające treści albo komentarze skierowane przeciwko określonym ludziom lub grupom ludzi (np. przeciw muzułmanom, imigrantom, Żydom, Romom)?

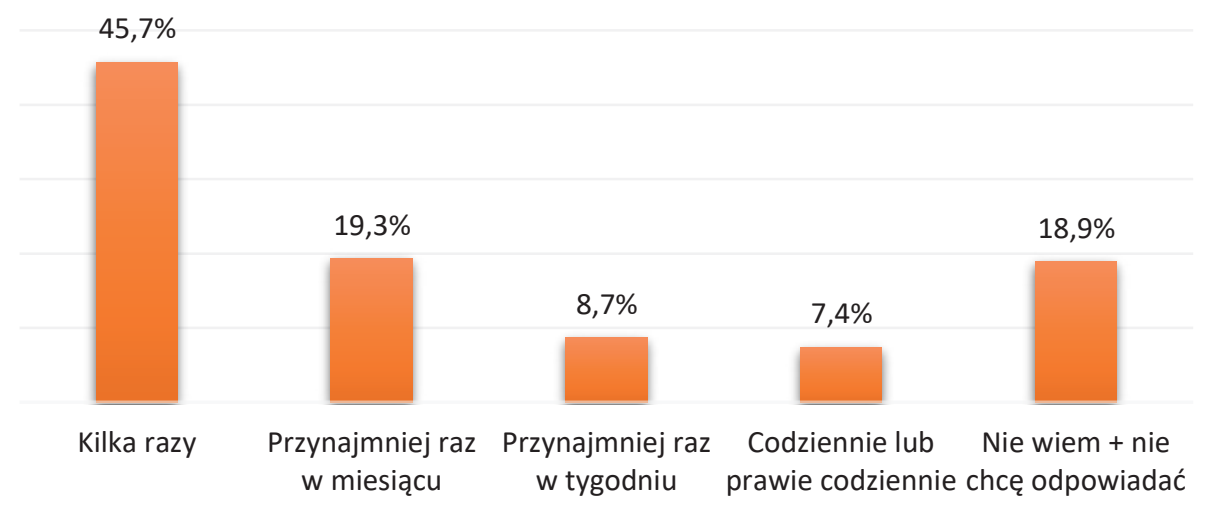

N=311 młodych osób w przedziale wiekowym 11-17 lat, które w ostatnim roku spotkały się z mową nienawiści w internecie

Niemalże co piąty nastolatek w ostatnim roku spotkał się z mową nienawiści przynajmniej raz w miesiącu. Najczęściej młode osoby napotkały w sieci treści szerzące nienawiść kilkukrotnie. Zjawisko mowy nienawiści nie jest dostrzegalne w dużym natężeniu lub bywa niedostrzegalne przez adolescentów. Nie ma istotnych różnic w częstotliwości dostrzegania zjawiska mowy nienawiści ze względu na płeć lub wiek. 


\section{Ważny fakt}

Zjawisko mowy nienawiści najczęściej dostrzegalne jest wśród osób deklarujących ekspozycję na analizowane zjawisko kilka razy na przestrzeni ostatnich dwunastu miesięcy.

Z badań przeprowadzonych w Niemczech, USA, Finlandii i Wielkiej Brytanii wśród młodych użytkowników internetu wynika, że narażenie na treści, które cechują się nienawistnym przekazem jest zróżnicowane ze względu na narodowość. Najczęściej, w ostatnich trzech miesiącach poprzedzających badanie, komunikaty tego typu dostrzegali młodzi użytkownicy w USA (53\%), kolejno w: Finlandii (48\%), Wielkiej Brytanii (38\%) oraz Niemczech (30.5\%). Czynnikiem, który najmocniej warunkował narażenie na hejt jest przeglądanie stron z „niebezpieczną zawartością” oraz intensywne użytkowanie portali społecznościowych (Hawdon, Oksanen, Räsänen, 2017). Biorąc pod uwagę polskie wyniki EU KIDS Online, należy podkreślić, że analizowane zjawisko jest zauważalne jedynie przez 1/3 ankietowanych, którzy najczęściej spotykają się z taką sytuacją sporadycznie.

\section{Poszukiwanie informacji klasyfikowanych jako mowa nienawiści}

Hejt i mowa nienawiści to określenia, które obejmują obrażanie innych osób, krytykowanie, wyśmiewanie, upokarzanie, artykułowanie destruktywnych treści pod czyimś adresem, pomówienia, oszustwa, atakowanie, agresywne wypowiedzi wobec osób lub grup. Działania takie mają na celu przede wszystkim wyrządzenie krzywdy (Global Dignity, 2016). Mowa nienawiści jest zjawiskiem, które obecnie narasta. Uwzględniając wyniki badań, np. EU NET ADB, wraz z wiekiem zmienia się dostrzegalność zjawiska hejtingu (Szymczak, 2015). Poniżej zaprezentowano rozkład odpowiedzi odnoszących się do intencjonalnego poszukiwania materiałów klasyfikowanych jako mowa nienawiści.

Celowe działania związane z poszukiwaniem treści zaliczanych do mowy nienawiści zadeklarowało na przestrzeni ostatniego roku 8,7\% badanych młodych osób w kategorii wiekowej 11-17 lat. Chłopcy nieco częściej szukają w sieci materiałów dotyczących mowy nienawiści niż dziewczęta. W starszych grupach wiekowych zaobserwowano trochę większe zainteresowanie tego typu działaniem niż w młodszych. 
Wykres 10.3. Czy w ciągu OSTATNIEGO ROKU zdarzyło się, że celowo szukałeś/aś nienawistnych lub poniżających treści albo komentarzy skierowanych przeciwko określonym ludziom lub grupom ludzi (np. przeciw muzułmanom, imigrantom, Żydom, Romom)?

Nie wiem + nie chcę odpowiadać

Nie

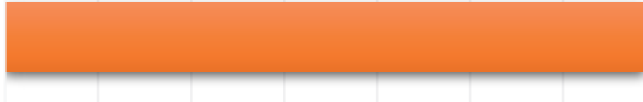

Tak

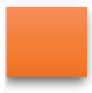

$8,7 \%$
$22,5 \%$

$68,8 \%$

$\mathrm{N}=996-$ młodzież w przedziale 11-17 lat

\section{Ważny fakt}

Czynnikami, które warunkują wyszukiwanie treści zaliczanych do mowy nienawiści, są wiek i płeć. Starsi chłopcy podejmują takie działania najczęściej.

Dane EU KIDS Online warto zestawić z wynikami słoweńskich badań (N=378), w ramach których wykazano, że respondenci poszukujący i czytający komentarze zaliczane do kategorii mowy nienawiści, najczęściej motywowani byli przez chęć pogłębienia wiedzy w danym obszarze, rozrywkowy wymiar zapoznawania się z wrogimi komentarzami lub chcieli pozyskaną negatywną wiedzę wykorzystać w kontaktach społecznych. Należy podkreślić, że wiek respondentów i poziom wykształcenia były negatywnie skorelowane ze wszystkimi wymienionymi powyżej rodzajami motywacji do zapoznawania się z mową nienawiści. Ci, którzy prowadzili większą liczbę aktywności online, czytali negatywne komentarze głównie w celach rozrywkowych. Interesujący jest fakt, że internetowe komentarze związane z mową nienawiści przyciągają w kategorii osób dorosłych większą liczbę aktywnych politycznie internautów (Erjavec, 2014). Analizując kwestie wyszukiwania tego typu komentarzy, należy wziąć pod uwagę również intencje, 
które kryją się za takimi działaniami. Uwzględnienie motywacji zapoznawania się z komentarzami oraz oddziaływania komentarzy lub treści na kształtowanie światopoglądu pozwala na zbudowanie pełniejszego obrazu analizowanego procesu.

\section{Otrzymywanie nienawistnych lub poniżające treści albo komentarzy}

Biorąc pod uwagę wyniki badań Global Dignity 2016, należy podkreślić, że w kategoriach wiekowych 12-14 lat 10\% ankietowanych zadeklarowało podejmowanie działań hejterskich, natomiast $28 \%$ było hejtowanych. Z kolei w obrębie grupy 15-16-latków co czwarty respondent podjął w swoim życiu działania mające na celu obrażanie innych, natomiast ponad połowa była ofiarą hejtera. Zjawisko to nasilało się wraz z wiekiem zarówno w wymiarze sprawstwa, jak i bycia ofiarą. Ponadto osób doświadczających hejtu było dwa razy więcej niż wyrządzających ten rodzaj krzywdy. Dla co siódmej młodej osoby hejt stał się zjawiskiem codziennym. Co trzecia osoba padła ofiarą mowy nienawiści, chociaż sama nigdy nie podejmowała takich działań. Zjawisko mowy nienawiści nasila się przede wszystkim w okresie szkoły średniej. Zjawisko hejtu nie jest marginalne i dotyczy wszystkich grup wiekowych. W tabeli nr 10.2 zaprezentowano procentowy rozkład otrzymywania nienawistnych lub poniżających komentarzy ukierunkowanych bezpośrednio na adolescentów lub ich społeczność.

Tabela 10.2. Czy w ciągu OSTATNIEGO ROKU Ty sam/a otrzymałeś/aś CHOĆ RAZ nienawistne lub poniżające treści albo komentarze skierowane przeciwko Tobie lub Twojej społeczności (np. przeciw muzułmanom, imigrantom, Żydom, Romom)?

\begin{tabular}{|c|c|c|}
\hline Tak \% & Nie $\%$ & Nie wiem + \\
\hline 8,7 & 69,3 & nie chcę odpowiadać $\%$ \\
\hline
\end{tabular}

$\mathrm{N}=996-$ młodzież w przedziale 11-17 lat

Niespełna $8,7 \%$ adolescentów na przestrzeni ostatniego roku otrzymało minimum jeden raz komunikat klasyfikowany jako mowa nienawiści. Wiek i płeć nie warunkuje narażenia na mowę nienawiści. Zebrane dane nie są spójne z danymi Global Dignity ze względu na interwał czasowy zaprezentowany w badaniu EU KIDS Online, w którym zawężono narażenie na nienawistne komunikaty do ostatnich dwunastu miesięcy. 


\section{Ważny fakt}

8,7\% młodych osób otrzymało w ostatnim roku komunikat klasyfikowany jako mowa nienawiści. Płeć i wiek nie różnicują otrzymywania tego typu informacji lub komentarzy.

Na wykresie 10.4 zaprezentowano procentowy rozkład częstotliwości doświadczania bezpośrednio mowy nienawiści. Dane dotyczą 8,7\% adolescentów, którzy spotkali się osobiście z mową nienawiści na przestrzeni ostatniego roku.

Wykres 10.4. Jak często w ciaggu OSTATNIEGO ROKU doświadczyłeś/aś osobiście mowy nienawiści?

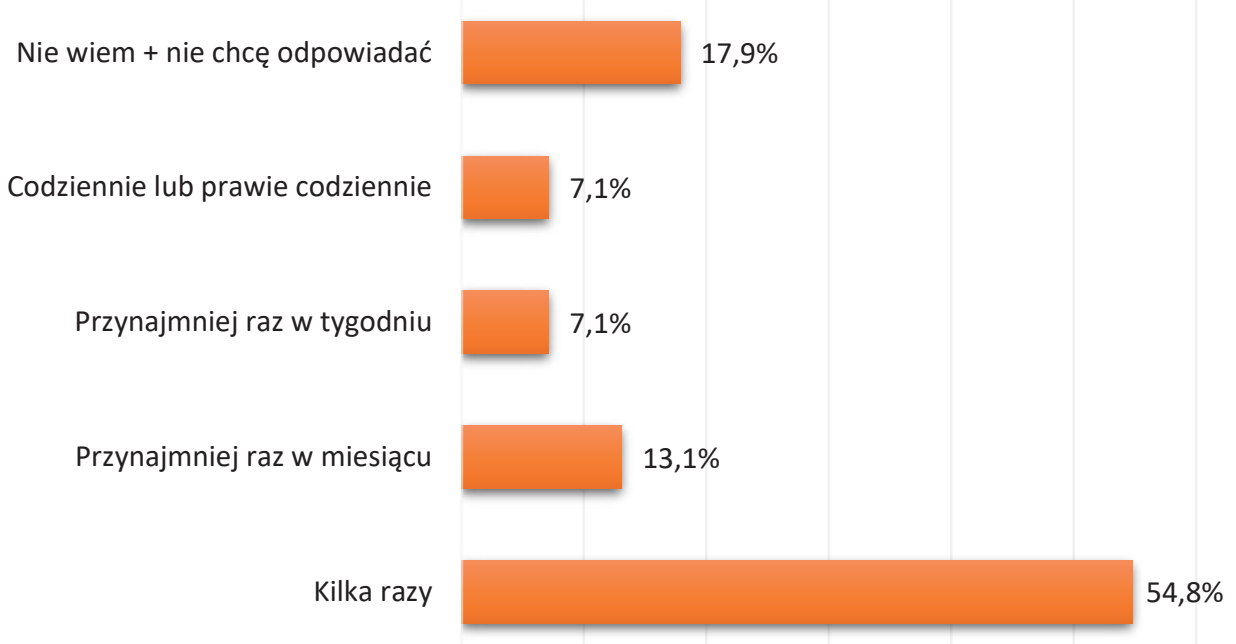

N=84 - młodzież w przedziale 11-17 lat, która doświadczyła bezpośrednio mowy nienawiści

Ponad połowa młodych osób objętych badaniem doświadczyła mowy nienawiści osobiście kilka razy w ciągu roku. Zjawisko to nie jest zatem powszechnie występujące, o czym świadczy deklaracja nieprzekraczająca 9\% z całej próby badawczej. Dodatkowo należy zaznaczyć, że wśród tej grupy ponad połowa określiła występowanie hejtu sporadycznie. 
Ważny fakt

Młode osoby doświadczyły mowy nienawiści sporadycznie kilka razy w roku.

Hejting jest specyficzną formą cyberprzemocy, bazującą w głównej mierze na krzywdzących wypowiedziach i komentarzach. Jest to zjawisko wpisujące się w definicję cyberprzemocy, które jest złożonym procesem wymagającym zróżnicowanych form oddziaływań profilaktycznych (Athanasiou i in., 2018). Ze względu na fakt, że zjawisko cyberprzemocy ujawnia się często w środowisku szkolnym, do roli instytucji edukacyjnych przypisywane jest rozwijanie umiejętności umożliwiających radzenie sobie z sytuacją agresji elektronicznej (Klement, Klementová, 2016). Zgromadzone w ramach EU KIDS dane warto zaprezentować na tle innych rezultatów badawczych. Z danych zebranych w lipcu 2015 r. przez Instytut Badań Edukacyjnych (raport „Bezpieczeństwo uczniów i klimat w polskich szkołach") wynika, że 25\% uczniów szkoły podstawowej i $29 \%$ z gimnazjum w ciągu czterech tygodni poprzedzających badanie IBE doświadczyło agresji elektronicznej. Łącznie ze zjawiskiem cyberprzemocy spotkał się co czwarty uczeń (NIK, 2017). Skala zjawiska nie zmienia się znacząco, lecz ewoluuje wraz z popularnością poszczególnych serwisów i aplikacji internetowych (Tomczyk, 2017).

\section{Postrzegane powody otrzymywania nienawistnych komentarzy lub treści}

Mowa nienawiści to działanie zazwyczaj ukierunkowane na jednostki i grupy charakteryzujące się wyróżniającymi je cechami. Hejting często wpisuje się w panujące trendy społeczne (Costello i in., 2017). Mowa nienawiści również łączona jest ze zjawiskiem manipulacji oraz ma podłoże w negatywnych zjawiskach występujących offline, takich jak: ksenofobia, skrajny nacjonalizm, seksizm (Mauersberger, 2017). Analizując zagadnienie mowy nienawiści w przestrzeni online, należy ściśle odwoływać się do mechanizmów towarzyszących analogicznym zjawiskom zachodzącym w środowisku offline. W ramach badan EU KIDS Online wyróżniono siedem „klasycznych” czynników, które współtowarzyszą atakom zapośredniczonym przez internet. Ich zestawienie procentowe w kontekście powodów otrzymywania nienawistnych komentarzy zaprezentowano na wykresie 10.5 . 
Wykres 10.5. Jak sądzisz, z jakiego powodu otrzymałeś/aś nienawistny komentarz? Czy było to z powodu...

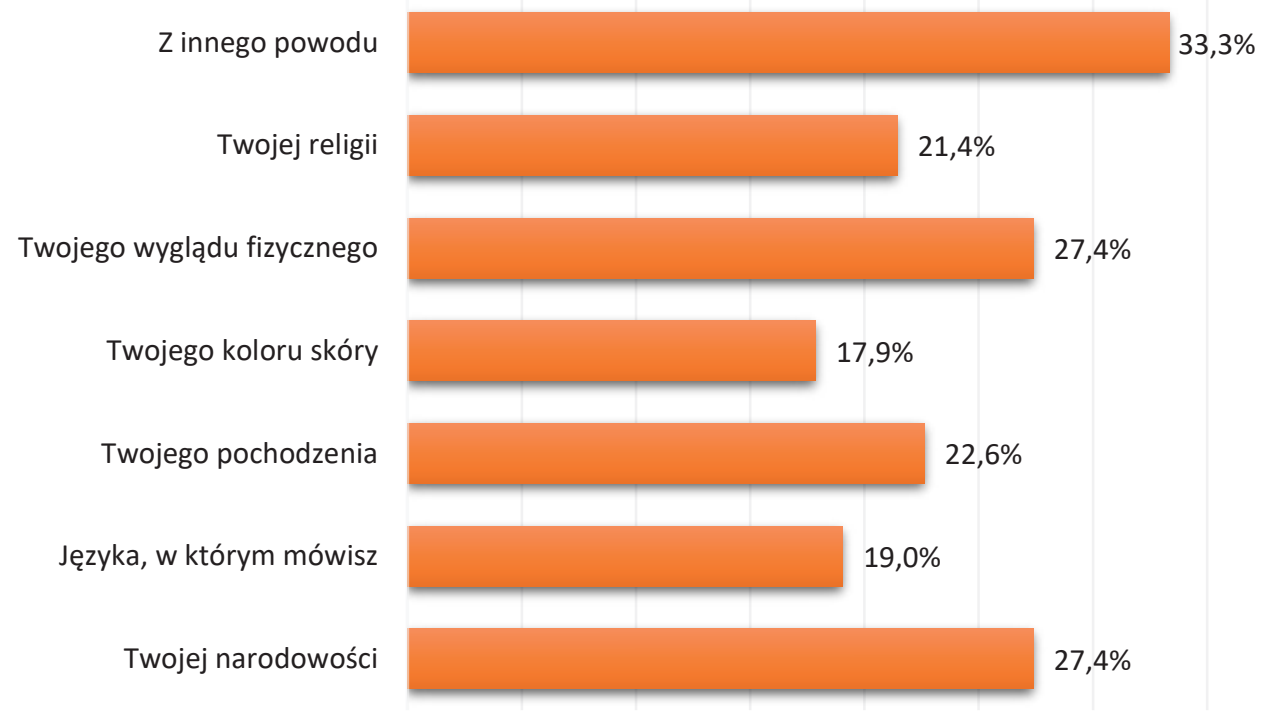

N=84 - młodzież w przedziale 11-17 lat, która doświadczyła bezpośrednio mowy nienawiści

Najczęstszym powodem, zdaniem badanych, związanym z otrzymywaniem nienawistnych komentarzy jest wygląd fizyczny, narodowość, pochodzenie. Co trzeci nastolatek, który otrzymał nienawistny komentarz zaznaczył, że nie było to działanie powiązane z żadną z kategorii wyodrębnionych na wykresie 10.5. Wygląd fizyczny jako przyczyna hejtu jest wskazaniem pojawiającym się dosyć często w innych polskich wynikach badań (Plichta, 2017; Plichta, Pyżalski, Barlińska, 2018).

\section{Ważny fakt}

Najczęstszym powodem otrzymywania nienawistnych komentarzy są - zdaniem adolescentów, którzy doświadczyli mowy nienawiści kwestie związane z wyglądem fizycznym i przynależnością narodową. 
Analizując rozległe wyniki badań na temat mowy nienawiści wśród Polaków (dorosłych i młodzieży), zdecydowana większość z ankietowanych posiada oczekiwania związane z egzekwowaniem zakazów związanych z atakami słownymi wobec Ukraińców i Afrykańczyków/osób czarnoskórych, ale jednocześnie jest w stanie zaakceptować mowę nienawiści ukierunkowaną na osoby LGBT, Romów, muzułmanów oraz Żydów. Jak podkreślają autorzy raportu wydanego przez Fundację im. Stefana Batorego: „młodzież w dużo większym stopniu niż dorośli Polacy styka się w swoim otoczeniu z mową nienawiści, jednak kontakt młodzieży z takimi wypowiedziami w małym stopniu wpływa na akceptację mowy nienawiści i na stosunek do obcych". Ponadto zgadzanie się na tego typu wypowiedzi nie jest powiązane z umiłowaniem wolności słowa, lecz łączy się raczej z wzrastającą agresją językową w społeczeństwie (Bilewicz i in., 2014b). Zaprezentowane wyniki stanowią podstawę do podkreślenia konieczności poszerzania kompetencji cyfrowych o składowe społeczne w ramach przedmiotów informatycznych, zajęć komputerowych, począwszy od młodszych klas. Wśród „miękkich” elementów kompetencji cyfrowych należy rozwijać umiejętność dotyczącą reagowania na mowę nienawiści oraz kształtowanie rozumienia mechanizmów kierujących sprawcami tego typu zachowań, wykraczając również poza przedmioty związane z ICT.

\section{Wysyłanie nienawistnych komentarzy lub poniżających treści}

Młodsi użytkownicy internetu są o wiele bardziej zaangażowani w umieszczanie różnorodnych postów niż starsze grupy wiekowe. Jednocześnie śledzenie komentarzy odnoszących się do własnego profilu nie jest istotnie zróżnicowane ze względu na wiek. Adolescenci w kategorii wiekowej 12-14 lat zamieszczają najwięcej pozytywnych wpisów w porównaniu z pozostałymi kategoriami wiekowymi (Global Dignity, 2016). Na tle powyższych wyznaczników stylu użytkowania mediów elektronicznych zaprezentowano procentowy rozkład odpowiedzi odnoszący się do hejtu.

Co piąty nastolatek nie chciał udzielić odpowiedzi na pytanie związane z wysyłaniem komunikatów będących mową nienawiści. Wysłanie w ciągu ostatniego roku chociaż jednej nienawistnej lub poniżającej treści albo komentarza skierowanego przeciwko określonym ludziom lub grupom ludzi (np. przeciw muzułmanom, imigrantom, Żydom, Romom) zadeklarowało 5,9\% ankietowanych. Chłopcy nieco częściej wysyłali nienawistne komentarze lub poniżające treści niż dziewczęta. W starszych grupach objętych badaniem (13-17 lat) można spotkać więcej osób, które wysłały obraźliwe komentarze. 
Wykres 10.6. Czy w ciągu OSTATNIEGO ROKU Ty sam/a CHOĆ RAZ wysłałeś/aś nienawistne lub poniżające treści albo komentarze skierowane przeciwko określonym ludziom lub grupom ludzi (np. przeciw muzułmanom, imigrantom, Żydom, Romom)?

Nie wiem + nie chcę odpowiadać

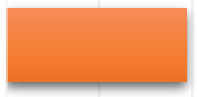

$19,4 \%$

Nie

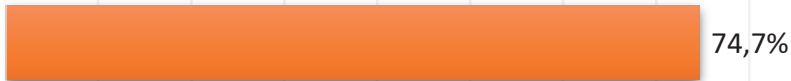

Tak $5,9 \%$

$\mathrm{N}=962-$ młodzież $\mathrm{w}$ przedziale 11-17 lat

\section{Ważny fakt}

Chłopcy oraz grupy 13-17-latków nieco częściej wysyłają wiadomości zaliczane do mowy nienawiści niż badani z młodszych grup (11-12 lat) oraz dziewczęta. W ciągu ostatniego roku 5,9\% adolescentów zadeklarowało wysłanie nienawistnego komunikatu.

Wśród sprawców agresji elektronicznej najczęściej przeważają chłopcy, jednakże w przypadku ataków mających charakter wynikający z relacji, proporcje pomiędzy płciami wyrównują się. Nie ma stuprocentowej zgodności co do zaprezentowanych współzależności. Owe zależności wymagają dalszych, pogłębionych analiz. Podobnie nie ma pewności co do wieku sprawców - szacuje się jednak, że intensywność korzystania z ICT powiązana jest z częściej występującym sprawstwem. Wraz z wiekiem rośnie częstotliwość działań zaliczanych do mowy nienawiści, ukierunkowanych na grupy i jednostki. Wśród cech, które potęgują działania związane z agresją czy też przemocą elektroniczną wymienia się także: pochodzenie z domów bez ustalonych zasad korzystania z mediów cyfrowych, pozytywne nastawienie do cyberprzemocy, osiąganie niższych wyników szkolnych, niskie wsparcie społeczne w placówkach szkolnych, słabe relacje w środowisku rodzinnym, występowanie innych zachowań ryzykownych (Pyżalski, 2011). 


\section{Częstotliwość działań związanych z mową nienawiści}

Na wykresie nr 10.7 zaprezentowano częstotliwość działań związanych z wysłaniem nienawistnych lub poniżających treści lub komentarzy skierowanych przeciwko określonym ludziom lub grupom ludzi. Zebrane dane dotyczą 5,9\% młodych osób, które zadeklarowały wysyłanie nienawistnych komunikatów w ostatnim roku.

Wykres 10.7. Jak często w ciągu OSTATNIEGO ROKU wysłałeś/aś nienawistny lub poniżający komentarz?

Trudno powiedzieć + wolę nie odpowiadać

Codziennie lub prawie codziennie

Przynajmniej raz w tygodniu

Przynajmniej raz w miesiącu

Kilka razy

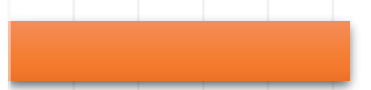

$26,3 \%$

$3,5 \%$

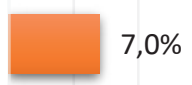

$7,0 \%$

$17,5 \%$

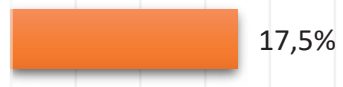

$45,6 \%$

N=57 - młodzież w przedziale 11-17 lat, która w przeciągu ostatniego roku wysłała komunikat klasyfikowany jako mowa nienawiści

Co czwarty nastolatek nie chciał udzielić odpowiedzi na temat częstotliwości wysyłania nienawistnych komentarzy. Warto jednak podkreślić, że niespełna połowa osób, które w ostatnim roku wysłały komunikat klasyfikowany jako mowa nienawiści, podjęła taką czynność kilkukrotnie. Analizując częstość stosowania mowy nienawiści, należy mieć również na względzie intencjonalność działania oraz kontekst występowania komunikatów. Wiek i płeć nie różnicują częstotliwości przesyłania nienawistnych komunikatów.

\section{Ważny fakt}

Badani adolescenci w wieku 11-17 lat mowę nienawiści realizują sporadycznie. 


\section{Powody występowania mowy nienawiści}

Do faktorów wyzwalających mowę nienawiści badacze zaliczyli przede wszystkim: uprzedzenia, ekspozycję na treści podobnego typu, działanie na przekór normom spotecznym, wysoki poziom racjonalizacji mowy nienawiści (Bilewicz i in., 2014b). Na wykresie $\mathrm{nr} 10.8$ zaprezentowano procentowy rozkład deklarowanych powodów łączonych z propagowaniem mowy nienawiści na przestrzeni ostatniego roku.

Wykres 10.8. Z jakiego powodu wysłałeś/aś nienawistny lub poniżający komentarz?

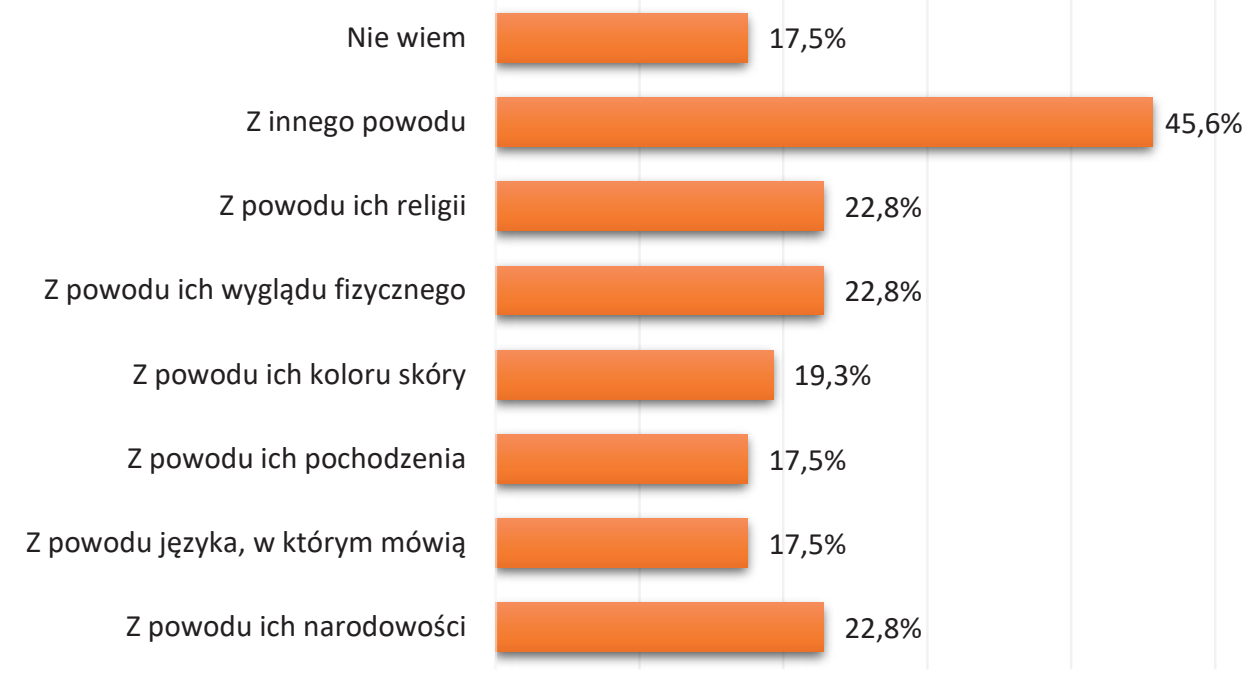

N=57 - młodzież w przedziale 11-17 lat, która w przeciągu ostatniego roku wysłała komunikat klasyfikowany jako mowa nienawiści

Wśród najczęstszych powodów powiązanych z występowaniem mowy nienawiści adolescenci wskazali kwestie: religii, wyglądu fizycznego oraz narodowości. Niespełna połowa osób wskazała inne czynniki niewymienione w ankiecie. Prawie co czwarty nastolatek nie wie, z jakiej przyczyny wysłał nienawistny komunikat. Każdy z wymienionych powodów jest wybierany o wiele częściej przez chłopców niż dziewczęta. 


\section{Ważny fakt}

Religia, wygląd fizyczny, narodowość są czynnikami wskazywanymi najczęściej jako powód mowy nienawiści. Chłopcy o wiele częściej wskazują każdą z wymienionych kategorii jako czynnik powiązany z występowaniem hejtingu.

Porównując powyższe wskazania z wynikami raportu z 2016 roku (Global Dignity, 2016), do powodów występowania hejtingu dodano również: chęć wyrażenia własnej opinii, brak zgody z treścią postu, poczucie zdenerwowania, reakcję na obrażanie bliskich osób lub interlokutora, irytację daną osobą, brak sympatii dla rozmówcy (Global Dignity, 2016). Zjawisko hejtingu można podzielić na działania celowe oraz przypadkowe. Druga kategoria motywacji związana jest również z osobami, które nie podejmują działań powiązanych z hejtingiem systematycznie, lecz działają pod wpływem impulsu. Ten rodzaj motywacji wynika najczęściej z niskiego poziomu samokontroli. 



\section{Materiały dotyczące seksu i zjawisko sekstingu}

Łukasz Tomczyk (Uniwersytet Pedagogiczny im. Komisji Edukacji Narodowej w Krakowie)

Użytkowanie mediów cyfrowych przez dzieci i młodzież najczęściej postrzegane jest w pedagogice mediów przez pryzmat paradygmatu ryzyka. Coraz częściej seksuolodzy oraz pedagodzy zwracają uwagę, że wybrane przekazy medialne charakteryzują się jawnymi lub aluzyjnymi odniesieniami do erotyki, czy też szerzej, seksualnej sfery życia ludzkiego. Jednocześnie eksperci podkreślają, że zbyt wczesna ekspozycja na treści o charakterze seksualnym, nieod powiednie konteksty powiązane z obrazem lub filmami mogą generować niekorzystne następstwa zdrowotne, psychologiczne i społeczne. Argumentem przemawiającym na niekorzyść wczesnego rozbudzania seksualności przez media jest jej powierzchowność oraz fałszywy obraz idący za przekazami medialnymi (Kubicka, 2007). Zasadniczym celem tworzenia i publikowania tego rodzaju treści jest pobudzenie seksualne użytkownika. Intensywne narażenie na treści medialne o charakterze seksualnym propaguje prymitywną wizję człowieka, którego zainteresowania koncentrują się na zaspokojeniu pożądliwości zmysłowej i przedmiotowym traktowaniu drugiego człowieka. Jednym z najbardziej kontrowersyjnych aspektów pornografii jest jej powszechna dostępność w internecie (Andrzejewska, Bednarek, 2014a).

Internet stanowi dla adolescentów jedno z głównych źródeł czerpania wiedzy na tematy związane ze sferą seksualną zaraz po rówieśnikach, telewizji i specjalistycznych publikacjach. W przestrzeni internetowej najczęstszym źródłem, z którego adolescen- 
ci czerpią wiedzę na temat zachowań seksualnych są strony pornograficzne, portale ogólnotematyczne lub fora internetowe. Najrzadziej młode osoby korzystają ze specjalistycznych serwisów dotyczących edukacji seksualnej czy też rozmów prowadzonych z innymi użytkownikami przez komunikatory (Jaszczak, 2008).

W Polsce dotychczas nie przeprowadzono zbyt wielu badań na temat recepcji pornografii i treści seksualizujących wśród dzieci i młodzieży. Warto jednak odwołać się w analizie wyników do rozległych badań zrealizowanych przez Fundację Dajemy Dzieciom Siłę (FDDS). Z zebranych danych wynika kilka istotnych faktów, m.in.: 43\% dzieci i nastolatków miało kontakt z treściami pornograficznymi; kategoria płci i wieku warunkuje dostęp do omawianego typu materiałów; starsza młodzież i chłopcy o wiele częściej oglądali materiały pornograficzne niż dziewczęta i dzieci; 20\% respondentów nie chciała udzielić odpowiedzi na ten temat; co piąty badany, który miał kontakt z pornografią, trafiał na takie materiały codziennie, a co czwarty - minimum raz lub dwa razy każdego dnia; do kontaktu z materiałami pornograficznymi zdecydowanie najczęściej dochodziło w przestrzeni internetowej - 92\% badanych wskazało ten obszar (Makaruk, Włodarczyk, Michalski, 2017). Polskie wyniki są zbieżne z zagranicznymi analizami. Przykładowo w ramach australijskiego badania kontakt z treściami pornograficznymi zgłosiło 87\% uczestników sondażu przeprowadzonego na próbie niespełna tysiąca młodych osób. Mediana wieku pierwszego kontaktu z pornografią internetową wynosiła 13 lat dla chłopców i 16 lat dla dziewcząt (Lim i in., 2017). Z kolei w młodszych grupach wiekowych, jak wynika z raportu Net Children Go Mobile, 28\% dzieci miało kontakt z treściami pornograficznymi (Mascheroni, Cuman, 2014). Dane te są spójne z polskim raportem Fundacji Dajemy Dzieciom Siłę.

Z wyników badań FDDS wyłania się obraz świadczący o tym, że ponad połowa dzieci (58\%), które miały kontakt z materiałami pornograficznymi lub seksualizującymi, twierdziła, że trafiła na tego typu treści przypadkowo. Co trzeci młody użytkownik mediów cyfrowych otrzymał materiały od najbliższych kolegów lub koleżanek. Celowo materiałów pornograficznych poszukiwał co trzeci adolescent. Powodami, dla których podejmowali takie czynności, były: chęć zaznania przyjemności, ciekawość, poszukiwanie informacji na temat seksu. W sposób przypadkowy z materiałami pornograficznymi częściej spotykały się młodsze dzieci i dziewczęta. Natomiast intencjonalnie treści tego typu poszukiwała zdecydowanie częściej starsza młodzież oraz chłopcy (Makaruk, Włodarczyk, Michalski, 2017).

Wśród czynników podnoszących ryzyko kontaktu z materiałami pornograficznymi badacze podkreślają znaczenie doświadczeń związanych z sekstingiem. Młode osoby wymieniające zdjęcia intymne o wiele częściej poszukiwały innych materiałów erotycz- 
nych i pornograficznych w sieci. Czynnikami równie istotnymi były: wczesna inicjacja seksualna, posiadanie stereotypów związanych z płcią, nadużywanie internetu, czy też niższe poczucie zadowolenia z życia (Makaruk, Włodarczyk, Michalski, 2017).

Specyficzną formą nadużyć związaną z udostępnianiem materiałów intymnych jest seksting. Zjawisko to dotyczy wysyłania własnych zdjęć lub filmów przez cyfrowe urządzenia. Dla młodych ludzi seksting jest dobrą zabawą, formą rozrywki. Jest to również technika pozwalająca na wyrażenie zainteresowania płcią przeciwną oraz sposób na przeżywanie pierwszych doświadczeń i fascynacji seksualnych. Rozwój własnej seksualności wraz ze współwystępowaniem analizowanego zjawiska rodzi jednak szereg obaw związanych z rozpowszechnieniem przekazywanych materiałów. Z pozoru niewinna zabawa może przynosić sporo negatywnych konsekwencji (Andrzejewska, Bednarek, 2014b). Należy jednak dodać, że w okresie dorastania (pomiędzy 12. a 17. rokiem życia) seksualność odgrywa ważne miejsce w życiu młodego człowieka. Etap ten łączy się z osiągnięciem dojrzałości płciowej i erotyzacją psychiki młodych osób. Dorastające osoby poszukują wiedzy na ten temat, próbują wypracować własne normy i postawy (Kubicka, 2007). Wśród powodów umieszczania lub przesyłania zdjęć intymnych zespół badawczy FDDS, oprócz kwestii wynikających ze specyfiki okresu rozwojowego, wymienił: chęć sprawienia przyjemności swojemu chłopakowi lub dziewczynie, realizację prośby bliskiej osoby, próbę zwrócenia na siebie uwagi, postępowanie dla żartu, próbę dokuczenia innej osobie (Makaruk, Włodarczyk, Michalski, 2017). Do czynników wzmacniających występowanie zjawiska sekstingu, naukowcy z czeskiego centrum PRVOK dodali: chęć wzbudzenia zainteresowania innych użytkowników sieci własną osobą, flirtowanie z osobami, które wzbudzają sympatię, chęć znalezienia chłopaka/ dziewczyny, chęć obdarowania bliskiej osoby własnym intymnym zdjęciem, odwzajemnienie się własnym zdjęciem za wcześniej otrzymaną fotografię, wysłanie fotografii lub filmu jako odpowiedzi na prośbę najbliższej osoby, chęć otrzymania nagrody od drugiej osoby, wymuszenie zdjęcia lub filmu przez chłopaka/dziewczynę, nuda (Tomczyk, Szotkowski, Kopecky, 2017).

W rozdziale 11. skoncentrowano się na ukazaniu skali zjawiska narażenia dzieci i młodzieży na materiały związane ze sferą seksualną oraz na następstwach wynikających z tej sytuacji, a także na kwestiach dotyczących sekstingu.

\section{Ekspozycja na treści pornograficzne}

Wykres nr 11.1 prezentuje procentowy rozkład narażenia młodzieży na jakiekolwiek obrazki/filmy związane z seksem w ostatnim roku. 
Wykres 11.1. Czy w ciągu OSTATNIEGO ROKU widziałeś/aś CHOĆ RAZ jakiekolwiek obrazki/filmy związane z seksem?

Nie wiem / nie chcę udzielić odpowiedzi

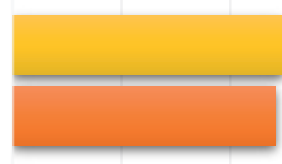

$24,9 \%$

$24,2 \%$

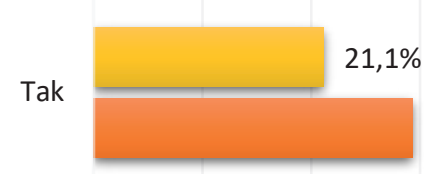

$29,3 \%$

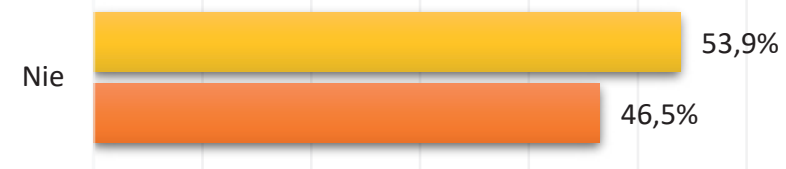

Dziewczęta Chłopcy

N=1249 - młodzi ludzie w wielu 9-17 lat, którzy widzieli materiały związane z seksem w ciągu ostatniego roku

Z treściami dotyczącymi seksu o wiele częściej spotykają się chłopcy niż dziewczęta. Niemalże co czwarty z nich na przestrzeni ostatniego roku widział jakikolwiek obraz związany z seksem. Skala zjawiska może być jednak o wiele większa, gdyż w każdej grupie niespełna 1/4 młodzieży nie udzieliła odpowiedzi na pytanie. Ze względu na istotne zróżnicowanie na płeć, dalsze analizy także będą uwzględniały rozbieżności i podobieństwa wynikające z takiego podziału. Równie ważnym elementem warunkującym narażenie na treści pornograficzne jest wiek ankietowanych.

\section{Ważny fakt}

Wraz z wiekiem wzrasta istotnie narażenie na odbiór materiałów dotyczących seksu. Im młodszy wiek tym mniejsze prawdopodobieństwo, że młoda osoba spotkała się w ostatnim roku z materiałami tego typu. 


\section{Formy przekazu i miejsca udostępniające materiały dotyczące seksu}

W tabeli $\mathrm{nr} 11.1$ zaprezentowano procentowy rozkład odpowiedzi odnoszących się do częstotliwości recepcji materiałów pornograficznych w wybranych formach przekazu. Wskazane w tabeli wartości odnoszą się do $24 \%$ badanej populacji, która zadeklarowała, że w ostatnim roku miała kontakt z materiałami dotyczącymi seksu.

Tabela 11.1. Jak często widziałeś/aś materiały dotyczące seksu w ciągu OSTATNIEGO ROKU w którymkolwiek z wymienionych miejsc?

\begin{tabular}{|c|c|c|c|c|c|c|c|}
\hline & Miejsce & $\begin{array}{l}\text { Nigdy } \\
\%\end{array}$ & $\begin{array}{c}\text { Kilka razy } \\
\%\end{array}$ & $\begin{array}{c}\text { Przynajmniej } \\
\text { raz } \\
\text { w miesiącu } \\
\%\end{array}$ & $\begin{array}{l}\text { Przynajmniej } \\
\text { raz w tygodniu } \\
\%\end{array}$ & $\begin{array}{c}\text { Codziennie } \\
\text { lub prawie } \\
\text { codziennie } \\
\%\end{array}$ & $\begin{array}{c}\text { Nie wiem } \\
\text { / Trudno } \\
\text { powiedzieć } \\
\%\end{array}$ \\
\hline a) & $\begin{array}{l}\text { W czasopiśmie albo } \\
\text { w książce }\end{array}$ & 49,4 & 33,3 & 5,8 & 2,9 & 1,0 & 7,7 \\
\hline b) & W telewizji, w filmie & 14,4 & 49,4 & 13,8 & 9,0 & 4,8 & 8,7 \\
\hline c) & $\begin{array}{l}\text { W telefonie komór- } \\
\text { kowym, komputerze, } \\
\text { tablecie albo innym } \\
\text { urządzeniu podłączo- } \\
\text { nym do internetu }\end{array}$ & 16,0 & 37,5 & 12,2 & 13,8 & 9,9 & 10,6 \\
\hline d) & $\begin{array}{l}\text { W serwisach udostęp- } \\
\text { niających pliki multime- } \\
\text { dialne (np. YouTube) }\end{array}$ & 39,7 & 26,6 & 7,7 & 5,1 & 4,8 & 16,0 \\
\hline e) & $\begin{array}{l}\text { W serwisach udo- } \\
\text { stępniających pliki } \\
\text { graficzne i zdjęcia } \\
\text { (np. Instagram, Flickr) }\end{array}$ & 43,6 & 22,8 & 7,1 & 5,4 & 5,1 & 16,0 \\
\hline f) & $\begin{array}{l}\text { W serwisach społecz- } \\
\text { nościowych (np. Face- } \\
\text { book, Twitter) }\end{array}$ & 37,5 & 27,9 & 5,4 & 6,4 & 5,8 & 17,0 \\
\hline g) & W grze online & 50,3 & 20,2 & 3,8 & 6,1 & 4,2 & 15,4 \\
\hline h) & $\begin{array}{l}\text { Na stronach z porno- } \\
\text { grafią (oznakowanych } \\
\text { jako strony tylko dla } \\
\text { dorosłych) }\end{array}$ & 46,8 & 13,5 & 8,0 & 5,8 & 6,1 & 19,9 \\
\hline i) & $\begin{array}{l}\text { W wyskakujących } \\
\text { okienkach (niechcia- } \\
\text { nych okienkach pop- } \\
\text {-up, które pojawiają } \\
\text { się w czasie ogląda- } \\
\text { nia stron WWW) }\end{array}$ & 31,3 & 26,9 & 8,7 & 11,2 & 5,1 & 17,0 \\
\hline
\end{tabular}




\begin{tabular}{|c|c|c|c|c|c|c|c|}
\hline j) & $\begin{array}{l}\text { W moim komputerze, } \\
\text { w wiadomości przesłanej } \\
\text { bezpośrednio do mnie }\end{array}$ & 63,5 & 10,9 & 5,8 & 3,5 & 1,6 & 14,7 \\
\hline k) & $\begin{array}{l}\text { W moim telefonie } \\
\text { komórkowym, w wia- } \\
\text { domości przesłanej } \\
\text { bezpośrednio do mnie }\end{array}$ & 57,1 & 17,6 & 4,5 & 3,8 & 2,6 & 14,4 \\
\hline I) & W wiadomości e-mail & 71,8 & 5,8 & 2,9 & 2,2 & 1,6 & 15,7 \\
\hline m) & $\begin{array}{l}\text { W reklamie interne- } \\
\text { towej }\end{array}$ & 31,3 & 31,7 & 9,3 & 8,0 & 3,5 & 16,3 \\
\hline n) & W jakimś innym miejscu & 51,6 & 17,9 & 3,8 & 3,5 & 1,9 & 21,2 \\
\hline
\end{tabular}

$\mathrm{N}=312$ - tylko młodzi ludzie w wielu 11-17 lat, którzy widzieli materiały związane z seksem w ciągu ostatniego roku

Osoby, które napotkały treści związane z seksem minimum kilka razy w ciągu roku, podkreślają, że sytuacja taka wystąpiła najczęściej w telewizji, reklamie internetowej, smartfonie. Minimum raz w tygodniu lub częściej materiały dotyczące seksu wyświetlane są poprzez smartfony, telewizję i niechciane okienka - reklamy pop-up. Zdecydowanie najrzadziej treści tego typu są propagowane przez wiadomości e-mail, komunikaty przesłane bezpośrednio przez telefon komórkowy. Interesujący jest również fakt, że z 24\% badanych, co piąty wskazuje, że istnieją również inne miejsca, gdzie spotyka się z materiałami związanymi z seksem, których jednak nie chce podać.

\section{Ważny fakt}

Wraz z wiekiem wzrasta prawdopodobieństwo narażenia na odbiór materiałów dotyczących seksu we wszystkich wymienionych formach przekazów medialnych. Najczęściej na treści związane z seksem młode osoby trafiają poprzez telewizję (13,8\% - minimum raz w tygodniu lub częściej), pojawiające się w sieci reklamy (16,3\% - minimum raz w tygodniu lub częściej) lub przy użyciu smartfona (23,7 \% - minimum raz w tygodniu lub częściej).

\section{Emocje a kontakt z materiałami związanymi z seksem}

Na wykresie nr 11.2 zaprezentowano procentowy rozkład uczuć towarzyszących zapoznawaniu się z pornografią. 
Wykres 11.2. Jak się czułeś/aś, kiedy ostatnio widziałeś materiały związane z seksem?

Nie wiem / Trudno powiedzieć

Byłem/am bardzo zdenerwowany/a

Byłem/am średnio zdenerwowany/a

Byłem/am trochę zdenerwowany/a

Ani się nie cieszyłem/am, ani nie byłem/am zdenerwowany/a

Cieszyłem/am się
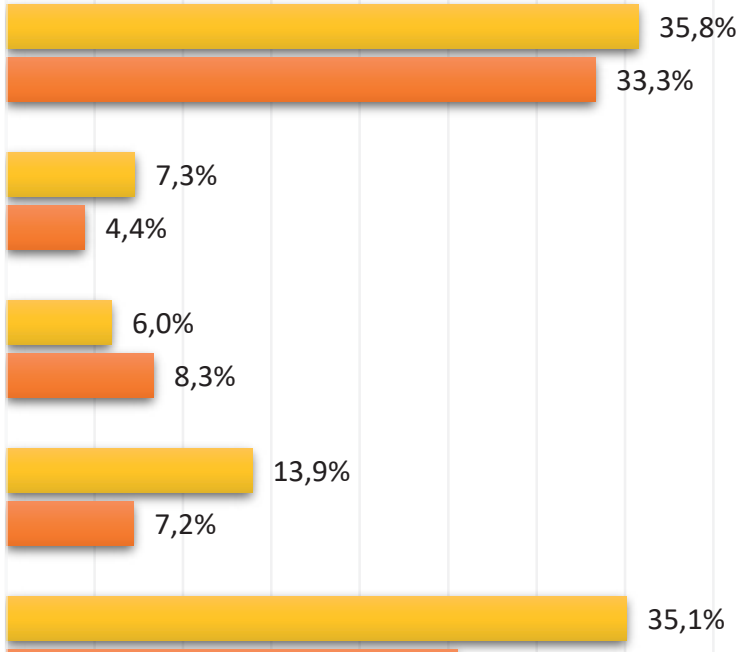

$35,1 \%$
$2,0 \%$

Dziewczęta Chłopcy

$\mathrm{N}=331$, młodzi ludzie w wieku 11-17 lat, którzy widzieli materiały związane z seksem w ciągu ostatniego roku

Wśród deklarujących kontakt z materiałami dotyczącymi seksu najczęściej ponad 1/3 respondentów nie jest w stanie określić uczuć towarzyszących im w tej sytuacji. Co czwarty chłopak oraz co trzecia dziewczyna nie odczuwali zdenerwowania czy też radości. Niemniej dwa aspekty zdecydowanie różnicującą badaną próbę ze względu na

\section{Ważny fakt}

Co czwarty chłopak, mający w przeciągu ostatniego roku doświadczenia w kontakcie z materiałami o charakterze seksualnym, odczuwał radość w trakcie wystąpienia takiej sytuacji. Dziewczęta nieco częściej denerwowały się w sytuacji zamierzonego lub przypadkowego kontaktu z materiałami dotyczącymi seksu niż chłopcy. Starsze grupy objęte badaniem odczuwały mniej negatywnych emocji w zetknięciu z materiałami związanymi z seksem. 
płeć. Po pierwsze, 21,1\% chłopców odczuwało radość w sytuacji wyświetlenia materiałów związanych z seksem, natomiast wśród dziewcząt jedynie 2\%. Ponadto dziewczęta nieco częściej denerwują się w sytuacji wyświetlenia tego typu treści.

\section{Otrzymywanie wiadomości związanych z seksem przez internet (seksting)}

Seksualizacja przestrzeni internetowej związana jest nie tylko z celowym lub przypadkowym napotkaniem treści dotyczących seksu, lecz również z otrzymywaniem przez różne kanały informacyjne zdjęć, obrazów lub filmów. Należy jednocześnie zaznaczyć, że wskazania w tabeli nr 11.2, odnoszące się do otrzymywania materiałów związanych z seksem, nie zawsze dotyczą zjawiska sekstingu, lecz opisywana sytuacja może wynikać z niechcianych komunikatów, np. spamu, nachalnych reklam, przekierowania na stronę internetową.

Tabela 11.2. Czy w ciągu ostatniego roku choć raz otrzymałeś/aś przez internet jakiekolwiek wiadomości związane z seksem? Chodzi o słowa, zdjęcia, obrazki lub filmy.

\begin{tabular}{|c|c|c|c|}
\hline Wiek & Odpowiedź & Chłopcy \% & Dziewczęta \% \\
\hline \multirow{3}{*}{ 11-12 lat } & Nie & 78,3 & 83,6 \\
\hline & Tak & 5,4 & 1,1 \\
\hline & Nie wiem / Trudno powiedzieć & 16,3 & 15,3 \\
\hline \multirow{3}{*}{ 13-14 lat } & $\mathrm{Nie}$ & 83,6 & 86,4 \\
\hline & Tak & 12,3 & 9,0 \\
\hline & Nie wiem / Trudno powiedzieć & 4,1 & 4,5 \\
\hline \multirow{3}{*}{ 15-17 lat } & $\mathrm{Nie}$ & 69,3 & 68,0 \\
\hline & Tak & 24,0 & 23,1 \\
\hline & Nie wiem / Trudno powiedzieć & 6,7 & 8,9 \\
\hline
\end{tabular}

$\mathrm{N}=985-$ młodzi ludzie w wielu 11-17 lat

W grupie starszej młodzieży znajduje się o wiele więcej osób, które otrzymały materiały związane z seksem. Co czwarty adolescent w kategorii wiekowej 15-17 lat ma tego typu doświadczenia. O połowę mniej deklaracji w tym zakresie można odnaleźć w kategorii wiekowej 13-14 lat. Jedynie 5\% chłopców i 1,1\% dziewcząt deklaruje otrzymywanie informacji o charakterze seksualnym w najmłodszej grupie wiekowej (11-12 lat). 


\section{Ważny fakt}

Wraz z wiekiem wzrasta prawdopodobieństwo otrzymania informacji przez internet związanej z seksem. W najstarszej grupie wiekowej objętej badaniem nie ma istotnych różnic ze względu na płeć w kontekście odbiorcy informacji o charakterze seksualnym.

\section{Częstotliwość otrzymywania wiadomości związanych z seksem przez internet}

Na wykresie nr 11.5 zobrazowano częstotliwość otrzymywania materiałów związanych z seksem. Ukazane odpowiedzi dotyczą jedynie próby 134 osób, a więc 16,6\% osób, które zadeklarowały otrzymanie wiadomości dotyczących seksu.

Wykres 11.3. Jeśli w ciągu OSTATNIEGO ROKU otrzymywałeś/aś przez internet wiadomości związane z seksem (np. słowa, zdjęcia, obrazki lub filmy), to jak często to się działo?

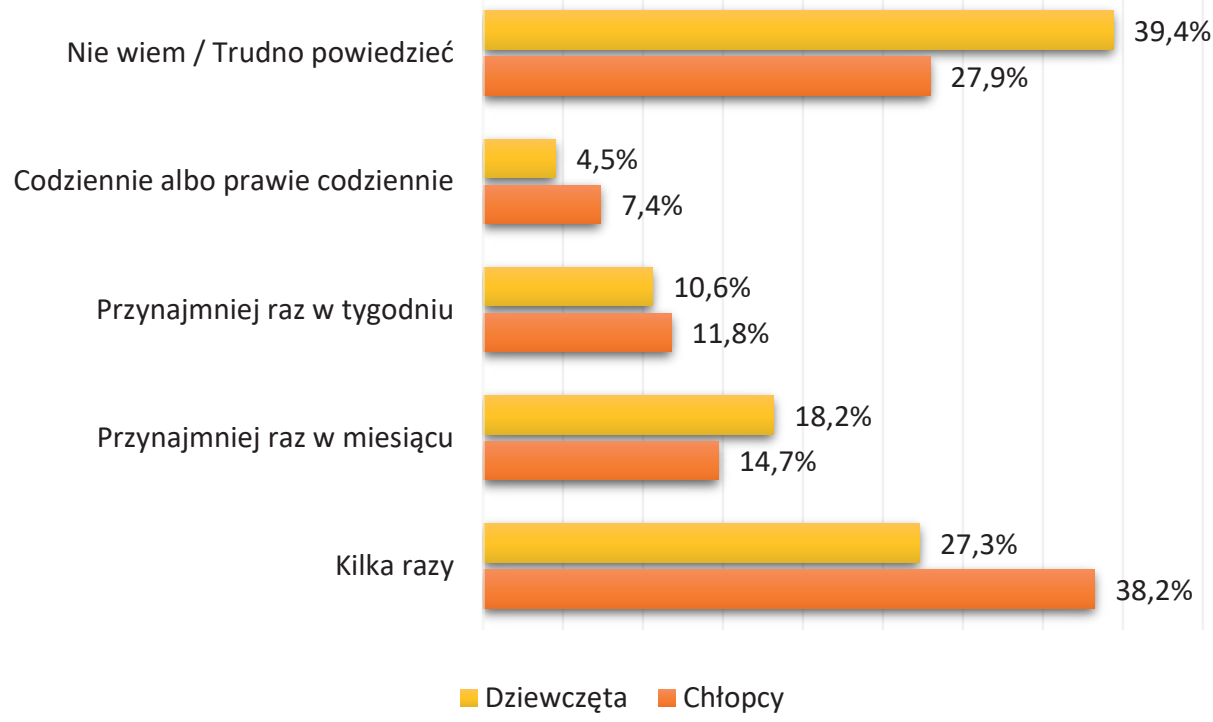

$\mathrm{N}=134$ - a więc $16,6 \%$ osób, które zadeklarowały otrzymanie wiadomości związanych z seksem

Chłopcy o wiele częściej deklarują otrzymywanie informacji związanych z seksem przez internet niż dziewczęta. Przynajmniej raz w tygodniu informację tego typu otrzymał co dziesiąty chłopak. Dziewczęta o wiele rzadziej chcą udzielać odpowiedzi na ten temat. 


\section{Ważny fakt}

Chłopcy częściej otrzymują materiały o charakterze seksualnym niż dziewczęta. Starsi chłopcy podkreślają, że otrzymują więcej wiadomości tego typu niż młodsi respondenci. Niespełna 40\% dziewcząt nie chce wskazać lub nie potrafi sklasyfikować otrzymywanych informacji.

\section{Emocje a kontakt z materiałami dotyczącymi seksu}

Na wykresie nr 11.6 zobrazowano uczucia występujące w sytuacji otrzymania materiałów - wiadomości zawierających treści seksualizujące. Zebrane dane dotyczą jedynie grupy, która wcześniej zadeklarowała otrzymanie tego typu wiadomości na przestrzeni ostatniego roku, a więc 16,6\% z badanej próby.

Wykres 11.4. Pomyśl o OSTATNIEJ SYTUACJI, kiedy otrzymałeś/aś wiadomość dotyczącą seksu/sekstingu. Jak się wtedy czułeś/aś?

Nie wiem / Trudno powiedzieć + wolę nie odpowiadać

Byłem/am bardzo zdenerwowany/a

Byłem/am średnio zdenerwowany/a

Byłem/am trochę zdenerwowany/a

Ani się nie cieszyłem/am, ani nie byłem/am zdenerwowany/a

Cieszyłem/am się

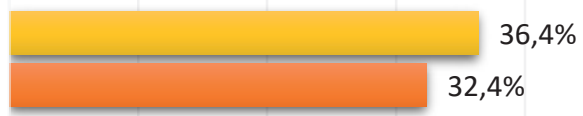

$9,1 \%$

$5,9 \%$

$10,6 \%$

$5,9 \%$

$9,1 \%$

$2,9 \%$

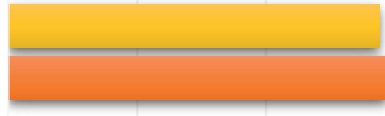

$28,8 \%$

$29,4 \%$

$6,1 \%$

$23,5 \%$

Dziewczęta Chłopcy

$\mathrm{N}=134$ - a więc $16,6 \%$ osób, które zadeklarowały otrzymanie wiadomości związanych z seksem 
Zdecydowana większość chłopców w przypadku otrzymania materiałów o charakterze seksualizującym wykazuje radość (niespełna 1/4 badanych). Wśród dziewcząt sytuacja ta dotyczy jedynie 6\% ankietowanych. Dziewczęta również o wiele częściej w sytuacji otrzymania tego typu materiałów denerwują się. Zbliżony odsetek chłopców jak i dziewcząt (ok. 1/3 ankietowanych) twierdzi, że otrzymanie takiej wiadomości nie wyzwala w nich żadnych emocji lub nie chce udzielić odpowiedzi na ten temat.

\section{Ważny fakt}

W sytuacji natrafienia na treści dotyczące seksu w tradycyjnych i nowych mediach występuje identyczna zależność jak w przypadku otrzymania materiałów - wiadomości o treści seksualizującej. Chłopcy wykazują o wiele większą radość niż dziewczęta w sytuacji kontaktu z tego typu treściami. Z kolei wśród dziewcząt można zauważyć większy liczbę deklaracji związanych z występowaniem uczucia zdenerwowania.

\section{Trwałość emocji w sytuacji kontaktu z treściami dotyczącymi seksu}

Uzupełniając powyższe dane należy dodać, że otrzymanie wiadomości zawierających treści erotyczne warunkuje występowanie emocji przez określony czas. Szczegółowy rozkład odpowiedzi na temat czasu trwania emocji zaprezentowano na wykresie nr 11.7. Należy podkreślić, że zebrane dane dotyczą 10,2\% ankietowanych, którzy zadeklarowali otrzymanie tego typu wiadomości.

Dziewczęta nieco częściej niż chłopcy nie chcą się dzielić informacją lub nie są w stanie określić długości trwania emocji w sytuacji kontaktu z treściami seksualnymi. Emocje częściej utrzymują się długotrwale wśród dziewcząt. Połowa ankietowanych deklaruje, że w trakcie kontaktu z materiałami seksualizującymi emocje mijają od razu.

\section{Ważny fakt}

Adolescenci w młodszych grupach wiekowych deklarują o wiele dłuższe występowanie negatywnych emocji niż starsi nastolatki objęci badaniem. Zauważalne jest również, że uczucie ambiwalencji mija bardzo szybko. 
Wykres 11.5. Jak długo odczuwałeś/aś emocje w sytuacji otrzymania wiadomości z treściami erotycznymi?

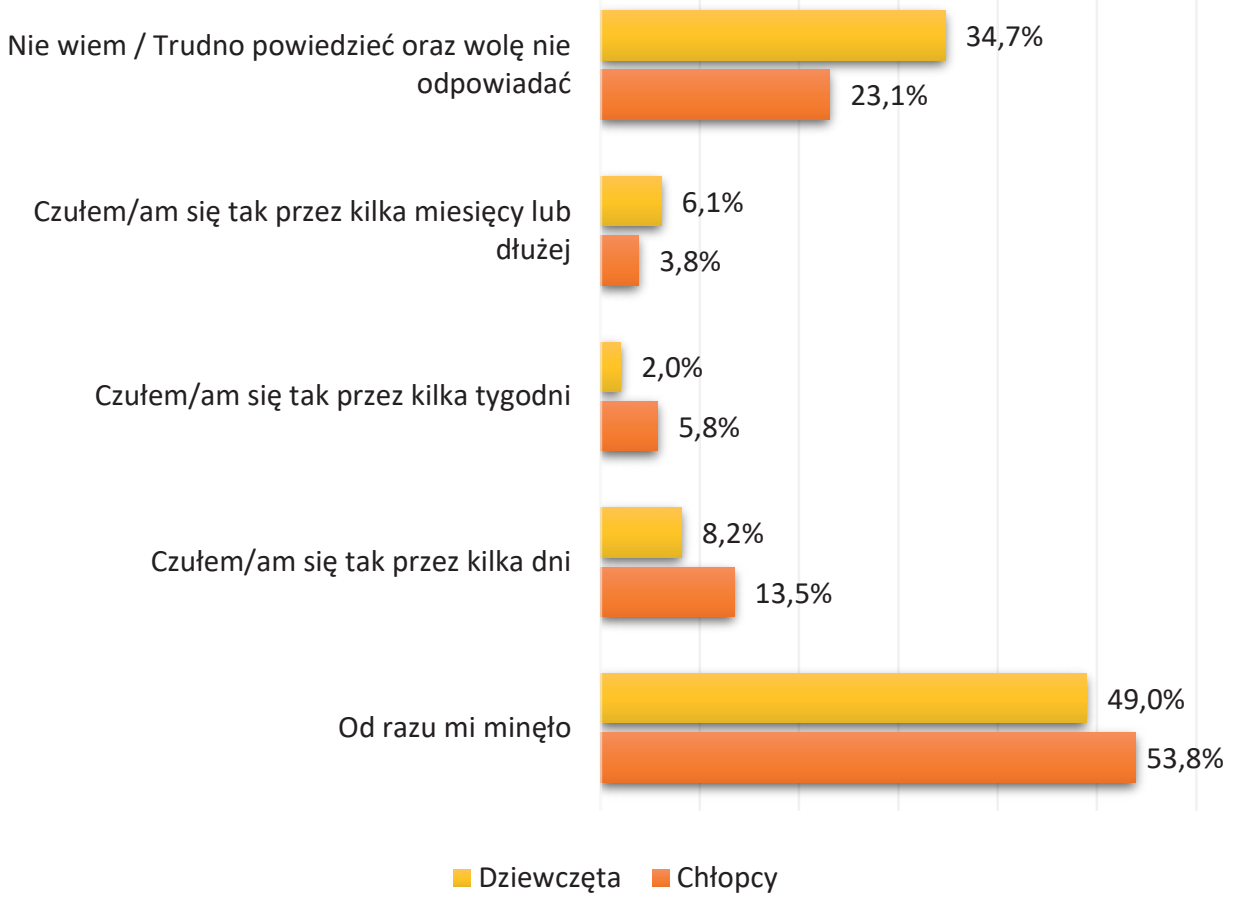

N=10 - zebrane dane dotyczą 10,2\% ankietowanych, którzy zadeklarowali otrzymanie wiadomości dotyczących treści erotycznych

\section{Umieszczanie lub wysyłanie wiadomości związanych z seksem}

Wykres nr 11.6 obrazuje rozpowszechnienie zjawiska sekstingu wśród badanych adolescentów. Na wykresie zaprezentowano częstotliwość wysłania lub umieszczania w internecie własnych zdjęć związanych tematycznie z seksem.

W badanej grupie adolescentów jedynie 3,8\% zadeklarowało, że w ostatnim roku wysłało lub umieściło zdjęcie, obrazek, film związany z zaprezentowaniem własnej osoby w kontekście seksualnym. Nie ma istotnej statystycznie różnicy pomiędzy płcią a deklaracją związaną z sekstingiem. W starszych grupach wiekowych zjawisko sekstingu występuje nieco częściej - sięgając wartości 5,33\% z całej badanej próby. 
Wykres 11.6. Czy w OSTATNIM ROKU kiedykolwiek WYSŁAŁEŚ/AŚ albo UMIEŚCIŁEŚ/AŚ w internecie wiadomości związane z seksem? To mogły być słowa, zdjęcia, obrazki lub filmy, na których widać Ciebie albo inną osobę.

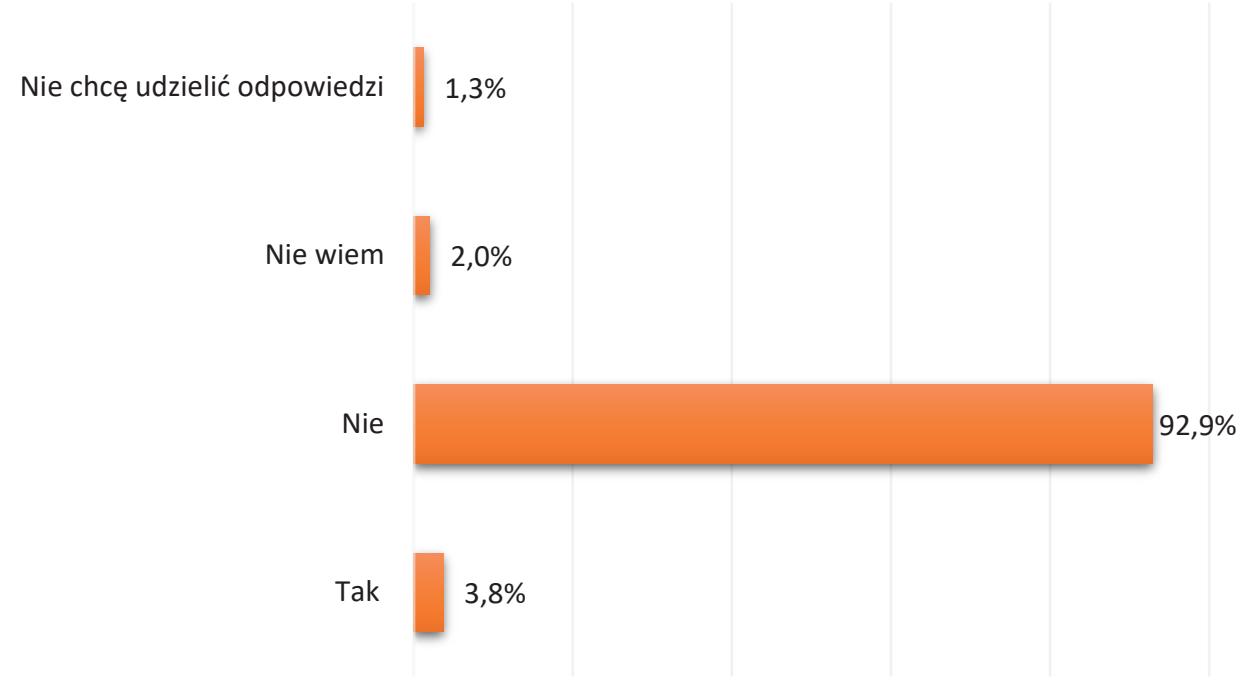

$\mathrm{N}=932$ - młodzi ludzie w wielu 11-17 lat objęci badaniem

\section{Ważny fakt}

Wraz z wiekiem wzrasta zjawisko sekstingu, sięgając do 5,33\% w najstarszej grupie wiekowej (15-17 lat), natomiast w najmłodszej analizowanej grupie (11-12 lat) wynosi 0,87\%.

\section{Skala sekstingu wśród młodzieży}

W tabeli nr 11.3 przedstawiono procentowy rozkład zachowań związanych z sekstingiem, dotyczących: przesyłania materiałów, umieszczania treści oraz nalegania na przesłanie zdjęć, obrazów, filmów o charakterze seksualnym. Zebrane dane dotyczą 3,8\% badanej próby, a więc wszystkich adolescentów, którzy zadeklarowali doświadczenia związane $z$ sekstingiem. 
Tabela 11.3. Jak często, w ciągu OSTATNIEGO ROKU, robiłeś/aś w internecie rzeczy wymienione poniżej?

\begin{tabular}{|c|c|c|c|c|c|c|c|}
\hline & Wykonywana czynność & $\begin{array}{l}\text { Nigdy } \\
\%\end{array}$ & $\begin{array}{c}\text { Kilka razy } \\
\%\end{array}$ & $\begin{array}{c}\text { Przynaj- } \\
\text { mniej raz } \\
\text { w miesiącu } \\
\%\end{array}$ & $\begin{array}{l}\text { Przynaj- } \\
\text { mniej raz } \\
\text { w tygodniu } \\
\%\end{array}$ & $\begin{array}{c}\text { Codziennie } \\
\text { lub prawie } \\
\text { codziennie } \\
\%\end{array}$ & $\begin{array}{c}\text { Nie wiem / Trud- } \\
\text { no powiedzieć + } \\
\text { nie chce } \\
\%\end{array}$ \\
\hline a) & $\begin{array}{l}\text { Wysłałem/am komuś } \\
\text { przez internet wiado- } \\
\text { mość związaną z sek- } \\
\text { sem (np. słowa, obrazki, } \\
\text { zdjęcia czy filmiki) }\end{array}$ & 8,6 & 25,7 & 25,7 & 20,0 & 8,6 & 11,4 \\
\hline b) & $\begin{array}{l}\text { Umieściłem/am } \\
\text { w internecie wiadomość } \\
\text { związaną z seksem (np. } \\
\text { słowa, obrazki, zdjęcia } \\
\text { czy filmy) w taki sposób, } \\
\text { że inni mogli to zobaczyć }\end{array}$ & 5,7 & 57,1 & 8,6 & 8,6 & 5,7 & 14,3 \\
\hline c) & $\begin{array}{l}\text { Prosiłem/am kogoś } \\
\text { w internecie o przysłanie } \\
\text { informacji o nim (o niej), } \\
\text { związanych z seksem, } \\
\text { np. jak wygląda jego(jej) } \\
\text { ciało bez ubrania albo } \\
\text { o rzeczach związanych } \\
\text { z seksem, które robił/a }\end{array}$ & 5,7 & 45,7 & 14,3 & 17,1 & 5,7 & 11,4 \\
\hline
\end{tabular}

N= 35 - młodzi ludzie w wielu 11-17 lat, którzy zadeklarowali zachowania klasyfikowane jako seksting

Co czwarty adolescent z grupy 3,8\% młodych osób mających doświadczenia z sekstingiem przynajmniej raz w miesiącu na przestrzeni ostatniego roku wysłał własne intymne zdjęcie. Około 80\% osób z tej grupy ma doświadczenia z umieszczeniem w sieci publicznej wiadomości związanej z seksem. Zbliżony odsetek młodych osób prosił kiedykolwiek inne osoby o intymne zdjęcia. W najstarszej starszej grupie wiekowej (15-17 lat) nieco częściej można dostrzec osoby, które mają doświadczenia w umieszczaniu własnych materiałów intymnych kilkakrotnie.

\section{Ważny fakt}

Zjawisko sekstingu dotyczy jedynie 3,8\% z badanej grupy. Wśród tej grupy czynności zaliczane do sekstingu najczęściej podejmowane były w ciągu ostatniego roku sporadycznie - kilka razy. 


\section{Wymuszenia intymnych zdjęć}

Zjawisko sekstingu może przyjąć formę dobrowolną lub wymuszoną, np. sextortion (zob. Patchin, Hinduja, 2018; Tomczyk, Szotkowski, Kopecky, 2017). Wymuszenie intymnych zdjęć nie jest zjawiskiem masowym, jednakże ze względu na następstwa jest szczególnie niebezpieczne. Na wykresie 11.7 zobrazowano skalę zjawiska wymuszania - próśb o zdjęcia intymne adresowanych do adolescentów.

Wykres 11.7. Jak często, jeśli w ogóle, w ciągu OSTATNIEGO ROKU, ktoś w internecie poprosił Cię o wysłanie informacji o Tobie związanych z seksem (słów, obrazków, zdjęć czy filmów), np. jak wygląda Twoje ciało bez ubrania, albo o rzeczach związanych z seksem, które robiłeś/aś, chociaż Ty nie chciałeś/aś na to odpowiadać?

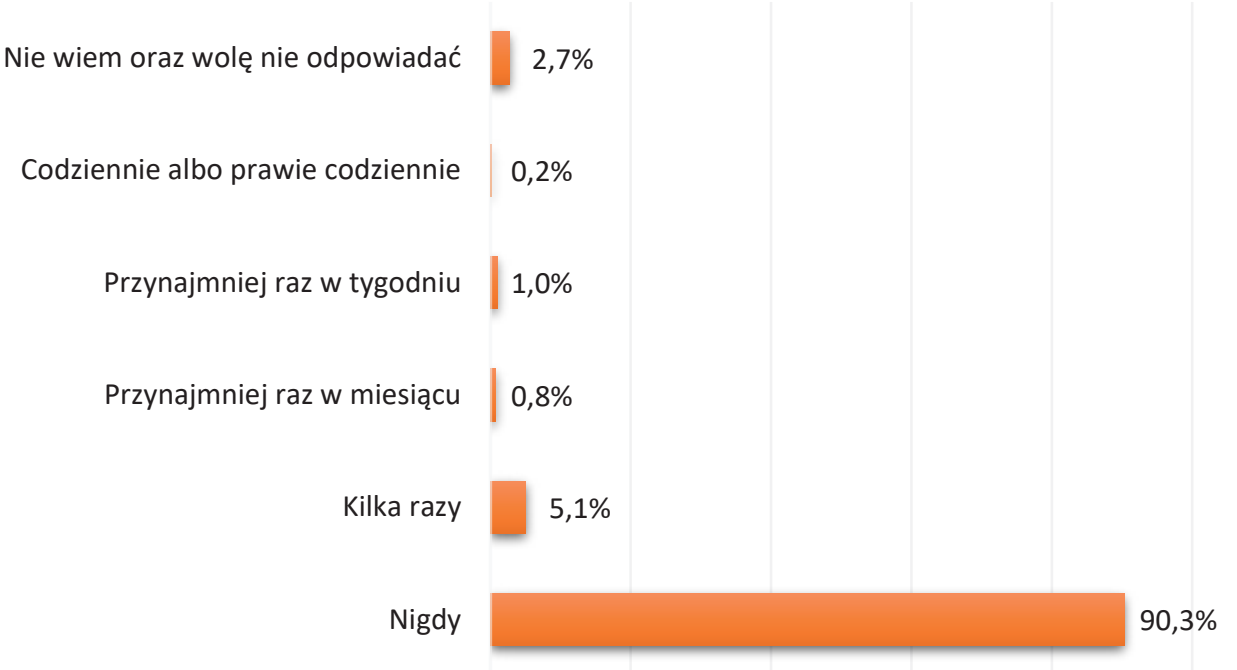

$\mathrm{N}=930-$ młodzi ludzie $\mathrm{w}$ wielu 11-17 lat

Na podstawie zebranych danych należy zauważyć, ze ponad 90\% adolescentów nie spotkało się z prośbą dotyczącą przesłania intymnych zdjęć czy też filmów. Jedynie 7\% miało do czynienia z taką sytuacją, z czego 5,1\% kilka razy w ciągu ostatniego roku. Niespełna 3\% nie chciało udzielić informacji na ten temat. Nie istnieje żadna widoczna zależność pomiędzy częstotliwością próśb o zdjęcie a wiekiem badanych. 
Ważny fakt

Zjawisko otrzymywania próśb o intymne zdjęcia w ciągu ostatniego roku dotyczy $7 \%$ badanej młodzieży. Najczęściej prośby te były wysłane sporadycznie (kilka razy w roku). Nieco częściej zapytania o zdjęcia intymne otrzymują dziewczęta.

\section{Dyskusja}

W młodszym wieku szkolnym zabezpieczenie przed treściami seksualizującymi może być realizowane przede wszystkim z wykorzystaniem programów filtrujących czy też dedykowanych przeglądarek, blokujących dostęp do nieadekwatnych do wieku treści. Nastolatki spędzają coraz więcej czasu w internecie. Jednocześnie w celu zapewnienia ochrony przed e-zagrożeniami część opiekunów korzysta z narzędzi do filtrowania treści internetowych. Należy podkreślić, że nie wszystkie rodzaje oprogramowania filtrującego spełniają swoje funkcje (Przybylski, Nash, 2018). Specjaliści w obszarze edukacji seksualnej zwracają szczególną uwagę na sytuację, w której rodzice są szczególnie odpowiedzialni za podjęcie dialogu z dorastającym nastolatkiem na temat uświadomienia, że pornografia internetowa nie jest metodą zdobywania rzetelnej informacji o seksualności człowieka. Ochrona dziecka we wskazanym obszarze to przede wszystkim zwracanie uwagi na negatywne konsekwencje łatwo dostępnych materiałów erotycznych, budujących skrzywiony obraz roli kobiety i mężczyzny. Postulat ten jest szczególnie ważny w świetle wyników badań EU KIDS Online, w ramach których stwierdzono, że co czwarty nastolatek miał kontakt z materiałami dotyczącymi seksu. Działania tego typu powinny być ukierunkowane o wiele bardziej w stronę chłopców, gdyż jak wynika ze zgromadzonych danych grupa ta charakteryzuje się odmienną formą przeżywania kontaktu z materiałami dotyczącymi seksu niż dziewczęta.

W dyskusji na temat oddziaływania tego typu materiałów na młodzież można spotkać się z opinią, że temat szkodliwości tej sfery internetowej stał się wyolbrzymiony (Spišák, 2016). Istnieją koncepcje, w ramach których zakłada się, że ze względu na łatwą dostępność materiałów pornograficznych oraz nakładającej się na ten fakt specyfiki wieku dojrzewania, związanej z odkrywaniem własnej seksualności, poszukiwanie filmów, zdjęć zawierających tło seksualne jest naturalnym elementem procesu rozwojowego (Naezer, 2018). Niemniej jednak badacze podkreślają, że narażenie na „konsumpcję” materiałów pornograficznych prowadzi do akceleracji zjawiska sekstingu, tworzy nega- 
tywne stereotypy, promuje odczłowieczone relacje (Stanley i in. 2018). Uwzględniając zebrane dane - w ramach których można zauważyć, że najczęściej materiały związane z seksem wyświetlane są poprzez smartfony, telewizję, reklamy - wyraźnie widać, że istnieje konieczność przekierowania uwagi na tradycyjne formy profilaktyczne, bazujące na wzmocnieniu kompetencji medialnych oraz podnoszeniu świadomości wśród adolescentów na temat wpływu komunikatów medialnych na zachowania ludzkie.

Z badań CBOS wynika, że jedynie 12\% osób dorosłych, zamieszkujących w gospodarstwie domowym z adolescentem, obawiała się, że przeglądając zasoby internetowe trafi na treści o charakterze pornograficznym (Feliksiak, 2015), natomiast w badaniu Fundacji Orange podkreślono, że treści tego typu stanowią poważne wyzwanie dla $36 \%$ rodziców. Kontakt z materiałami pornograficznymi i erotycznymi został ulokowany zaraz za zagrożeniami typu: uzależnienie od internetu oraz nawiązywanie kontaktów z osobami poznanymi przez sieć (Orange, 2016). Rola rodziców w kształtowaniu kompetencji cyfrowych dotyczących bezpieczeństwa w sieci związana jest przede wszystkim z budowaniem pozytywnych relacji rodzinnych, a także uświadamianiem zagrożeń wynikających z nieadekwatnych do wieku treści oraz mechanizmów związanych z rozpowszechnieniem zdjęć intymnych (Bayraktar, 2017; Bayraktar i in., 2016). Rolą osób znaczących jest wyjaśnienie sposobów ochrony przed sytuacjami niezamierzonymi, np. nieumyślnym przekierowaniem na strony pornograficzne, erotyczne czy też radzenia sobie z nachalnymi reklamami.

Z danych FDDS wynika, że wraz z wiekiem wzrasta częstotliwość wysyłania intymnych zdjęć przez adolescentów. Zjawisko to dotyczy 10\% chłopców w wieku 15-16 lat oraz 12\% dziewcząt w tej samej kategorii wiekowej. Z kolei do otrzymania erotycznych zdjęć przyznaje się ok. 40\% młodych respondentów niezależnie od wieku (Makaruk, Włodarczyk, Michalski, 2017). Z amerykańskich wyników badań można zauważyć, że 24\% nastolatków otrzymało materiały zaliczane do sekstingu. Z kolei 17\% wysłało własne intymne zdjęcia lub filmy (Rice i in., 2018). Hiszpańskie wyniki badań również ukazują kilkunastoprocentowe występowanie zjawiska, gdyż ok. 13,5\% nastolatków w kategorii wiekowej 12-17 lat podzieliło się własnymi zdjęciami intymnymi (Gámez-Guadix i in., 2017). Czeskie wyniki badań Centrum Ryzyka Wirtualnej Komunikacji PRVOK potwierdzają, że ok. 15\% nastolatków miało doświadczenia z przesłaniem własnego intymnego zdjęcia (Tomczyk, Szotkowski, Kopecky, 2017). Na tle wspomnianych badań zaskakujące są wyniki badań EU KIDS Online, z których wynika, że jedynie 3,8\% nastolatków wysłało własne intymne fotografie za pomocą mediów cyfrowych. Dodatkowo w tej niewielkiej grupie $80 \%$ ankietowanych uczestniczyło w sekstingu sporadycznie. Wyniki badań są zaskakujące, jednakże z jednej strony mogą świadczyć o wzmocnieniu 
kompetencji cyfrowych młodych osób, m.in. za sprawą realizowanych w Polsce programów edukacji medialnej lub wynikają z błędów przyporządkowanych do ilościowych technik zbierania danych w obszarze tematów intymnych.

Wyniki badań Net Children Go Mobile pokazują, że najczęściej o materiały seksualizujące proszone są dziewczęta. Chłopcy natomiast o wiele częściej upubliczniają zgromadzone materiały w sieci bez zgody osoby uwidocznionej na zdjęciu (Mascheroni, Cuman, 2014). Wykonane zdjęcia bardzo często wrzucane są do sieci lub rozsyłane znajomym w ramach zemsty przez byłych partnerów. Zmultiplikowane fotografie są trudne do usunięcia ze względu na zdecentralizowany charakter internetu (Andrzejewska, Bednarek, 2014b). Zidentyfikowana w raporcie Net Children Go Mobile tendencja jest zgodna z polskimi wynikami badań, gdyż nieco częściej o intymne zdjęcia proszone są dziewczęta niż chłopcy.

W skrajnym przypadku seksting może przyczynić się do upublicznienia zdjęć, cyberprzemocy, szantażu. Zjawisko sekstingu może stać się niebezpieczne w sytuacji nadużycia zarchiwizowanych zdjęć lub filmów. Wśród głośnych przypadków należy wymienić między innymi historię amerykańskiej nastolatki Jessicki Logan z Ohio, która wysłała swojemu chłopakowi intymne zdjęcia. Po tym jak ze sobą zerwali, mężczyzna rozesłał zdjęcia do kilkudziesięciu uczniów z okolicznych szkół. Na skutek drwin ze strony rówieśników nastolatka popełniła samobójstwo. Równie głośną sprawą była sytuacja dotycząca Amandy Todd, której intymne zdjęcia zostały upublicznione w SNS, natomiast szantażysta doprowadził do załamania nerwowego i depresji nastolatki. Jej list pożegnalny został opublikowany w serwisie YouTube. W Polsce najgłośniejszą sytuacją była sprawa 14- letniej Ani z 2006 roku, która była napastowana seksualnie przez kolegów w szkole. Cała sytuacja została zarejestrowana telefonem komórkowym. Pod wpływem wydarzenia nastolatka targnęła się skutecznie na własne życie, pomimo braku upublicznienia filmu w internecie. Sprawa ta wywołała duże oburzenie społeczne i stała się przyczyną do namysłu nad kwestią archiwizacji i rozpowszechniania materiałów o charakterze seksualnym (Wojtasik, 2015). Tendencja wymuszenia zdjęć intymnych sięga kilku procent (do 7\% w ciągu ostatniego roku). Zebrane dane w ramach EU KIDS są spójne z innymi wynikami badań, np. zrealizowanymi w ostatnim czasie w Stanach Zjednoczonych (Patchin, Hinduja, 2018). 


\section{Podsumowanie i wnioski}

Jacek Pyżalski (Uniwersytet im. Adama Mickiewicza w Poznaniu)

Aldona Zdrodowska (Ośrodek Przetwarzania Informacji - Państwowy Instytut Badawczy)

Łukasz Tomczyk (Uniwersytet Pedagogiczny im. Komisji Edukacji Narodowej w Krakowie)

Katarzyna Abramczuk (Ośrodek Przetwarzania Informacji - Państwowy Instytut Badawczy)

Na wstępie tego badania warto wskazać jego walory, ale także zaakcentować ograniczenia, które zawsze wpisane są w każdy projekt badawczy.

Atuty zrealizowanego projektu to:

1. Badanie EU Kids Online Polska obejmuje bardzo szeroki zakres zagadnień związanych z szansami i zagrożeniami użytkowania internetu przez młodych ludzi. Pozwala to skonstruować rodzaj aktualnej mapy opartej na tej problematyce.

2. Badanie bazuje na doświadczeniu naukowym silnego konsorcjum czołowych europejskich badaczy zajmujących się problematyką funkcjonowania młodych ludzi w kontekście internetu; jest kontynuacją przełomowych dla tej problematyki badań EU Kids Online zrealizowanych w latach 2009-2010.

3. Badanie uwzględnia rolę dwóch kluczowych środowisk mających wpływ na jakość wykorzystania internetu przez młodych ludzi: domu i szkoły. Pozwala to nie tylko rozpoznać ich znaczenie w modelowaniu wzorów korzystania z internetu, ale także budować w przyszłości szczegółowe, praktyczne rekomendacje związane z szeroko rozumianym wychowaniem i dydaktyką w erze cyfrowej. 
4. Badanie zostało zrealizowane na reprezentatywnej próbie młodych ludzi w wieku 9-17 lat; dotyczy zatem bardzo szerokiej grupy wiekowej, co umożliwia w znaczącej części uwzględnionej kwestii szereg porównań międzygrupowych dzieci i młodzieży.

5. Badanie wykonano przy zastosowaniu ujednoliconej metodologii w 15. krajach UE, co pozwoli - po jego zakończeniu - na dokonanie porównań międzykulturowych.

6. Badanie uwzględnia najnowsze ważne kwestie związane z funkcjonowaniem młodych ludzi online, np. problem mowy nienawiści czy zachowania świadków przemocy w internecie.

7. Badanie uwzględnia zaangażowanie online młodych ludzi w kontekście tego, co robią oni offline.

Słabsze strony naszego projektu są dosyć oczywiste. Po pierwsze, podejmując nawet tak wiele kwestii, jak w tym badaniu, zawsze zostaną inne, którymi warto się zająć. Jako badacze musieliśmy podjąć decyzję, choćby na etapie wyboru pytań nieobowiązkowych, czyli takich, które nie były obligatoryjne we wszystkich krajach. Staraliśmy się, by wybór był jak najlepszy, opierając go o własne doświadczenia badawcze i znajomość rezultatów innych projektów badawczych zrealizowanych w Polsce.

Po drugie, nawet te kwestie, które zostały wybrane mogły zostać empirycznie rozpoznane jedynie na określonym poziomie szczegółowości. To cena, jaką zawsze trzeba zapłacić, chcąc uzyskać szeroki obraz. Sama długość narzędzia badawczego i związany z nią czas wypełniania kwestionariusza nakładają tu ograniczenia. Jest zatem tak, że osoby interesujące się szczególnie określonymi zagadnieniami, np. wykorzystaniem internetu w szkole, zawsze będą odczuwać poznawczy niedosyt.

Wreszcie w odniesieniu do samej książki, chcemy zwrócić uwagę, że jest to wstępna publikacja prezentująca jedynie najważniejsze i wybrane przez nas wyniki oraz wnioski. Będziemy je oczywiście uzupełniać i pogłębiać w następnych planowanych publikacjach, podejmujących szczegółowo poszczególne badane kwestie.

Wśród najważniejszych tendencji, jakie ukazują nasze badania, należy zwrócić uwagę na rosnącą rolę urządzeń mobilnych. które w przypadku części młodych ludzi stają się kluczowymi urządzeniami do łączenia z internetem (nie korzystają oni nigdy lub prawie nigdy z internetu stacjonarnego). Badania pokazały także, że internet rzeczy (internet of things), np. zabawki podłączone do 
internetu, są używane niezmiernie rzadko, a ich użytkowanie stanowi dopiero rozwijający się trend.

Mobilne łączenie się z internetem przekłada się na to, że mamy obecnie do czynienia nie z jednym, lecz wieloma sposobami bycia online, przeplecionymi z innymi aktywnościami, które podejmujemy. Wyraźny kiedyś, choćby w roku 2010, gdy realizowano pierwsze badanie EU Kids Online, jednoznaczny podział na sytuacje, kiedy byliśmy online lub offline, uległ znaczącemu rozmyciu. Oznacza to w przyszłości konieczność dostosowania metodologii badań do zmieniającej się sytuacji w tym zakresie. Jednocześnie inaczej należy rozumieć pod kątem jakościowym czas spędzany przez młodych ludzi na wykorzystaniu internetu.

Samo używanie internetu jest powszechne. Widać tu jednak spore zróżnicowanie wśród młodych ludzi, których często uważa się za jednorodnych pod tym względem. Stosunkowo dużo, bo ponad 40\% badanych, korzysta z internetu do 2 godzin w dni powszechnie i do 3 godzin w weekendy. Jednocześnie blisko 19\% młodych ludzi w dzień weekendowy korzysta z internetu 6 godzin i więcej, ale tylko co dziesiąty tak długo korzysta w dzień wolny od nauki szkolnej,

Warto też zwrócić uwagę, że niewielu młodych ludzi nadaje korzystaniu z sieci szczególnego znaczenia w kontekście swojego funkcjonowania w szerszym zakresie. Jedynie 7\% uważa, że zawsze łatwiej jest im być sobą w internecie, niż wtedy gdy spotykają się z ludźmi twarzą w twarz. Ten i inne wyniki naszego badania wskazują, że myślenie „interneto-centryczne” o funkcjonowaniu dzieci i młodzieży jest dużym uproszczeniem. Tracimy przez nie wiele możliwości wglądu w to, co jest naprawdę istotne w kontekście życia i rozwoju współczesnego młodego pokolenia.

Adolescenci używają mediów cyfrowych najczęściej w celach informacyjno-rozrywkowych. Młodzież jest zazwyczaj biernym odbiorcą informacji, a prawdziwie twórcze wykorzystanie tych informacji jest już zjawiskiem marginalnym. Niedostatek konstruktywnego używania internetu stanowi jedno z wyzwań dla pedagogiki mediów. Grupa młodych użytkowników sieci jest niehomogeniczna, zatem analizując pozytywne i negatywne aspekty zachowań z wykorzystaniem mediów cyfrowych, należy mieć na względzie panujące zróżnicowanie w stylach użytkowania sieci (np. różny czas online w zależności od wieku). Zaprezentowane w ramach EU KIDS Online wyniki badań są spójne z innymi polskimi i zagranicznymi raportami badawczymi, obrazującymi sposoby korzystania z internetu przez młodych internautów.

W odniesieniu do środowiska szkolnego w codziennej praktyce przeważają proste rozwiązania w zakresie wykorzystania internetu, które nie wnoszą wiele 
nowej jakości do dydaktyki. Sposoby wykorzystania sieci wymagające kreowania treści, komunikacji z innymi (uczniami i nauczycielami), poszukiwania i oceny wiarygodności informacji są zbyt rzadko stosowane.

Jednocześnie zaskakująco wielu uczniów wskazało, że żaden nauczyciel nie podejmował z nimi różnych aktywności z zakresu edukacji medialnej. Brak ten dotyczył nawet bardzo prostych, podstawowych spraw, jak rozmowa z uczniami o tym, co robią w internecie. Oznacza to, że w wielu sytuacjach, w kontekście wychowawczym, szkoła zbyt rzadko nawiązuje w tym obszarze do życia młodych ludzi. Jeśli dodatkowo nie włącza się tutaj środowisko rodzinne, to pozostaje w tym zakresie edukacja rówieśnicza, która niestety tylko w części sytuacji działa pozytywnie. Częściowo lukę tę mogą wypełniać i wypełniają inicjatywy organizacji pozarządowych, działających np. w świetlicach szkolnych czy środowiskowych oraz instytucjach kultury.

Wyraźnie widać, że szkoła potrzebuje koncepcji i wsparcia w zakresie „oswajania” internetu zarówno w sferze dydaktyki, jak i wychowania. Niewątpliwie, ze względu na bogactwo problemów i rolę internetu w życiu młodych ludzi nie rozwiążą tych wszystkich kwestii zajęcia komputerowe/informatyczne. Cyfryzacja szkół, w tym podłączenie ich do szybkiego internetu bez sensownych rozwiązań pedagogicznych, nie daje szans na dobre efekty, co zresztą pokazały wyniki badań, które cytujemy w odpowiednim rozdziale.

W ramach projektu EU KIDS Online zebraliśmy także nowe dane na temat strategii wychowawczych stosowanych przez rodziców i opiekunów w celu zwiększania korzyści i minimalizowania ryzyka dla dzieci i nastolatków korzystających z technologii sieciowych. Jak wynika z wypowiedzi młodych respondentów, polscy rodzice najchętniej sięgają po aktywne metody wsparcia, takie jak rozmowy na temat bezpieczeństwa w sieci, a najmniej chętnie wykorzystują rozwiązania technologiczne (np. oprogramowanie) służące redukowaniu narażenia na zagrożenia online. W przypadku dzieci młodszych rodzice często posiłkują się dodatkowo metodami restrykcyjnymi, tj. formułowaniem reguł i ograniczeń w zakresie korzystania przez dziecko z internetu i innych technologii sieciowych (np. smartfonów). Same dzieci także proaktywnie poszukują wsparcia u rodziców i opiekunów, gdy doświadczają problematycznych sytuacji online lub gdy chcą po prostu porozmawiać o swoich aktywnościach w sieci. Postawy młodych internautów wobec rodzicielskich metod ochrony i wsparcia w internecie są, podobnie jak wykazano w pierwszym badaniu EU Kids Online, raczej pozytywne. 
Nowym zagrożeniem, z punktu widzenia młodych użytkowników sieci, jest umieszczanie w internecie przez rodziców różnego rodzaju danych (komentarzy, zdjęć, filmów itp.) na temat swoich dzieci - bez pytania ich o zgodę. Choć problem ten dotyka stosunkowo niewielkiej grupy dzieci, te które go doświadczają, odczuwają negatywne emocje w związku z nieszanowaniem przez rodziców ich prawa do prywatności oraz przykre konsekwencje w postaci nieprzyjemnych komentarzy innych osób w internecie.

W ramach projektu EU KIDS Online pozyskano również istotne dane na temat edukacji rówieśniczej w zakresie bezpieczeństwa cyfrowego. Młodzi użytkownicy, w świetle swoich deklaracji, posiadają zróżnicowany poziom kompetencji cyfrowych. Młode osoby najczęściej dzielą się wiedzą na temat technicznej obsługi internetu, najrzadziej zaś wymieniają się informacjami w obszarze etycznej oceny treści internetowych oraz budowania bezpiecznych kontaktów z innymi użytkownikami sieci. Obszar ten stanowi kolejne wyzwanie, nie tylko w dziedzinie edukacji medialnej, lecz szeroko rozumianego rozwoju edukacji rówieśniczej.

Zdecydowana większość badanych nastolatków (w wieku 11-17 lat) ma kontakt z różnego rodzaju szkodliwymi treściami w internecie, które mogą prowadzić do samouszkodzeń lub wyrządzenia krzywdy innym ludziom bądź zwierzętom. Dotyczy to zwłaszcza starszej młodzieży. Tylko 28\% nastolatków zadeklarowało jednoznacznie, że nie miało styczności z żadnym z wymienionych rodzajów szkodliwych treści. Jednocześnie jednak zdecydowanej większości młodych ludzi udaje się uniknąć bycia ofiarą poważnych naruszeń prywatności i oszustw internetowych. Najpowszechniejszymi zagrożeniami w tej dziedzinie, oprócz kontaktu ze złośliwym oprogramowaniem, są nadużycie osobistych informacji i uzyskanie dostępu do prywatnych haseł. Nieco mniej niż połowa badanych nastolatków szuka nowych znajomości w internecie. Połowa tych, którzy to robią, przenosi takie znajomości poza sieć. Spotkania zainicjowane w sieci częściej kończą się pozytywnymi niż negatywnymi emocjami. W obliczu niepokojącej sytuacji w internecie dzieci i młodzież najczęściej wycofują się z niej, licząc na to, że problem rozwiąże się sam. Jeśli decydują się o tym z kimś porozmawiać, najczęściej zwracają się do swoich rówieśników.

Problematyczne Użytkowanie Internetu (PUI) na przestrzeni ostatnich lat stało się jednym z najbardziej zauważalnych negatywnych zjawisk dotyczących przeobrażenia sposobów użytkowania mediów cyfrowych. Do tej pory nie ma zgodności co do jednoznacznych kryteriów diagnostycznych charakteryzujących PUI. Niepokój rodziców oraz obawy pedagogów związanych z mediami cyfrowymi coraz 
częściej sytuują PUI jako jedno z dominujących zagrożeń. W badaniu EU KIDS Online stwierdzono, że ponad 82\% nastolatków nie posiada żadnego z objawów PUI w najbardziej skrajnym natężeniu. Z kolei ponad 17\% posiada którykolwiek z nich, natomiast 9,2\% jeden z siedmiu czynników charakteryzujących analizowane zjawisko. Wyniki badań EU KIDS Online, obrazujące między innymi skalę PUI poprzez pryzmat siedmiu kluczowych czynników, wpisują się w dyskusję na temat powszechności zjawiska uzależnienia od internetu wśród młodych osób.

Cyberprzemoc rówieśnicza, gdy definiujemy ją jako zjawisko doświadczane przez ofiarę czy też dokonywane przez sprawcę regularnie, jest zjawiskiem relatywnie rzadkim - dotyczy ono co dwudziestego badanego jako sprawcy i nieco powyżej 7\% populacji tych, którzy są ofiarami. Nie należy jednak tego zjawiska bagatelizować ze względu na jego istotne negatywne skutki dla wszystkich zaangażowanych (w tym świadków). Za bardzo poważnym traktowaniem zjawiska cyberprzemocy przemawia także fakt jego wyraźnego powiązania z przemocą rówieśniczą twarzą w twarz. Problem dotyczy tu szczególnie ofiar, które są atakowane właściwie bez przerwy i we wszystkich kontekstach. Oznacza to także, że programy profilaktyczne nastawione wyłącznie na problem cyberprzemocy mogą być nieskuteczne, gdyż nie uwzględniają problemu zaburzenia relacji rówieśniczych we wszystkich kontekstach.

Mowa nienawiści jest zjawiskiem coraz lepiej poznanym naukowo. Obecnie w literaturze przedmiotu można odnaleźć szereg raportów charakteryzujących skalę zjawiska, mechanizmy towarzyszące temu rodzajowi komunikacji. Mowa nienawiści nie jest sytuacją specyficzną dla nowych mediów. Jej przejawy widoczne są również w analogowych odpowiednikach. Biorąc pod uwagę właściwości internetu 2.0, bycie sprawcą mowy nienawiści jest sytuacją niewymagającą wyspecjalizowanych narzędzi czy też umiejętności. W ramach przeprowadzonych analiz zauważono, że niespełna co trzeci nastolatek spotkał się w ostatnich dwunastu miesiącach w internecie z mową nienawiści. Sytuacja ta wystąpiła jednak sporadycznie. Najczęstszym powodem otrzymywania agresywnych komentarzy jest: wygląd fizyczny, narodowość, pochodzenie. Zjawisko mowy nienawiści jest specyficzną formą agresji elektronicznej lub cyberprzemocy, wymagającą dalszych pogłębionych badań i działań profilaktycznych w grupie młodych użytkowników mediów cyfrowych.

Internet umożliwia szybki dostęp do różnego rodzaju treści. Ta niewątpliwie pozytywna cecha mediów cyfrowych przynosi jednak szereg zagrożeń związanych z łatwym dostępem do zawartości nieadekwatnej do wieku. Wśród kwestii bu- 
dzących obawy osób dorosłych, dotyczących użytkowania internetu przez dzieci i młodzież, często wymieniane jest narażenie na materiały związane z seksem. Na podstawie wyników EU KIDS Online zauważono, że wraz z wiekiem znacząco wzrasta narażenie dzieci i młodzieży na materiały dotyczące seksu. Interesujący jest jednak fakt, że materiały tego typu widoczne są dla młodych osób zarówno w tradycyjnych, jak i nowych mediach. Internet nie jest jedynym kanałem dystrybucji treści o charakterze seksualnym. Na podstawie zgromadzonych danych zauważono również, że chłopcy i dziewczęta różnią się w zakresie emocji, jakie wywołuje u nich kontakt z materiałami związanymi z seksem. Zebrane dane pozwoliły także na określenie skali zjawiska sekstingu, który wyniósł 3,8\% na przestrzeni ostatniego roku, natomiast sytuacje otrzymywania próśb o intymne zdjęcia w ciągu ostatniego roku dotyczyły 7\% w badanej próbie starszej młodzieży. Oba odsetki stanowią podstawę do analiz długoterminowych zjawiska sekstingu i narażenia młodych osób na treści seksualizujące.

Generalny obraz młodych ludzi w kontekście wykorzystania internetu nie jest jednoznaczny. Z pewnością nie jest tak ciemny, jak myślą niektórzy przekonani o powszechności ryzyk i zachowań dysfunkcjonalnych online. Nie jest on też bardzo optymistyczny - młodzi ludzie nie jawią się powszechnie jako konstruktywni i twórczy użytkownicy. Wiele jest nierówności w tym obszarze - i wizja „typowego” dziecka czy nastolatka jako użytkownika internetu jest z pewnością nieuprawnionym uogólnieniem.

Zapraszamy Czytelników naszej publikacji do własnych analiz, dyskusji i polemik, i liczymy na to, że książka ta stanie się punktem wyjścia dla nowych projektów badawczych oraz źródłem inspiracji dla praktycznych pedagogicznych inicjatyw.

\section{Podziękowania}

Zespół badawczy EU Kids Online Polska 2018 dziękuje prezes Fundacji Orange Ewie Krupie i jej Zespołowi za współpracę i wsparcie procesu badawczego oraz upowszechniania wyników badania.

Dziękujemy także recenzentom: dr hab. Natalii Walter z Uniwersytetu im. Adama Mickiewicza w Poznaniu oraz dr. hab. Piotrowi Plichcie z Uniwersytetu Wrocławskiego, za szereg uwag i rad, które pozwoliły nam podnieść jakość niniejszej publikacji.

Podziękowania za owocną współprace przy przygotowaniu niniejszej publikacji kierujemy też do Dyrekcji i Zespołu Wydawnictwa Naukowego UAM. 



\section{Bibliografia}

Alt, D., Boniel-Nissim, M. (2018). Parent-Adolescent Communication and Problematic Internet Use: The Mediating Role of Fear of Missing Out (FoMO). „Journal of Family Issues”, 39 (13), 3391-3409, [online] <https://doi.org/10.1177/0192513X18783493>.

Andrzejewska, A., Bednarek, J. (2014a). Pornografia. [W:] J. Lizut (red.), Zagrożenia cyberprzestrzeni. Warszawa: Wyższa Szkoła Pedagogiczna im. J. Korczaka.

Andrzejewska, A., Bednarek, J. (2014b). Seksting. [W:] J. Lizut (red.), Zagrożenia cyberprzestrzeni. Warszawa: Wyższa Szkoła Pedagogiczna im. J. Korczaka.

Arslan, S., Kırık, A. M., Karaman, M., Çetinkaya, A. (2015). Digital Addiction in High School and University Students. „International Peer-Reviewed Journal of Communication and Humanities Researches", (8), 34-34. DOI:10.17361/uhive.2015813153.

Athanasiou, K., Melegkovits, E., Andrie, E. K., Magoulas, C., Tzavara, C. K., Richardson, C., Tsitsika, A. K. (2018). Cross-National Aspects of Cyberbullying Victimization among 14-17-yearold Adolescents across Seven European Countries. „BMC Public Health”, 18 (1), N.PAG, [online] <https://doi.org/10.1186/s12889-018-5682-4>.

Barbovschi, M., Marinescu, V., Velicu, A., Laszlo, E. (2012). Meeting New Contacts Online. [W:] S. Livingstone, L. Haddon, A. Görzig (red.), Children, Risk and Safety on the Internet. Bristol: The Policy Press, 177-189. 
Barlińska, J., Lalak, D., Szuster, A. (2018). Jak skutecznie ograniczyć cyberprzemoc rówieśniczą? - o efektywności metod aktywizujących kompetencje społeczne ze szczególnym uwzględnieniem empatii. „Dziecko Krzywdzone. Teoria, Badania, Praktyka”, 17 (1), 68-95.

Barlińska, J., Szuster, A., Winiewski, M. (2013). Cyberbullying Among Adolescent Bystanders: Role of the Communication Medium, Form of Violence and Empathy. „Journal of Community and Applied Social Psychology", 37-51.

Batorowska, H. (2013). Od alfabetyzacji informacyjnej do kultury informacyjnej. Rozważania o dojrzałości informacyjnej. Warszawa: Stowarzyszenie Bibliotekarzy Polskich.

Batorski, D. (2015). Technologie i media w domach i w życiu Polaków. Diagnoza Społeczna 2015. Warunki i jakość życia Polaków - Raport. „Contemporary Economics”, nr 9/4, 373395. DOI:10.5709/ce.1897-9254.1.

Bauman, S. (2013). Cyberbullying: What Does Research Tell Us?, „Theory Into Practice”, 4, 249-256.

Bayraktar, F. (2017). Online Risks and Parental Mediation Strategies Comparison of Turkish Children/Adolescents Who Live In Turkey and Europe. TED EĞiTiM VE BiLiM. DOI:10.15390/ eb.2017.6323.

Bayraktar, F., Barbovschi, M., Kontrikova, V. (2016). Risky Sociability and Personal Agency-Offline Meetings with Online Contacts Among European Children and Adolescents. "Children and Youth Services Review", 70, 78-83. D0I:10.1016/j.childyouth.2016.09.007.

Bigum, C., Bulfin, S., Johnson, N. F. (2015). Critical Is Something Others (Don't) Do: Mapping the Imaginative of Educational Technology. [W:] S. Bulfin, N. F. Johnson, C. Bigum (red.), Critical Perspectives on Technology and Education (1st ed., Vol. 43, 1-13). New York: Palgrave Macmillan.

Bilewicz, M., Marchlewska, M., Soral, W., Winiewski, M. (2014). Mowa nienawiści. Raport z badań sondażowych. Warszawa: Fundacja im. Stefana Batorego.

Bilewicz, M., Soral, W., Marchlewska, M., Winiewski, M. (2017). When Authoritarians Confront Prejudice. Differential Effects of SDO and RWA on Support for Hate-Speech Prohibition. „Political Psychology", 38 (1), 87-99, [online] <https://doi.org/10.1111/pops.12313>.

Blum-Ross, A., Livingstone, S. (2017). "Sharenting," Parent Blogging and the Boundaries of the Digital Self. „Popular Communication: The International Journal of Media and Culture”, 15 (2), 379-387.

Brosch, A. (2017). Sharenting - nowy wymiar rodzicielstwa? [W:] H. Krauze-Sikorska, M. Klichowski (red.), Świat małego dziecka. Przestrzeń instytucji, cyberprzestrzeń i inne przestrzenie dzieciństwa. Poznań: Wydawnictwo Naukowe UAM, 19-30.

Chetty, N., Alathur, S. (2018). Hate Speech Review in the Context of Online Social Networks. „Aggression \& Violent Behavior", 40, 108-118, [online] <https://doi.org/10.1016/j. avb.2018.05.003>.

Clark, L. (2011). Parental Mediation Theory for the Digital Age. "Communication Theory”, 21, 323-343. 
Costello, M., Hawdon, J., Ratliff, T. N. (2017). Confronting Online Extremism: The Effect of Self-Help, Collective Efficacy, and Guardianship on Being a Target for Hate Speech. „Social Science Computer Review", 3 (5), 587-605, [online] <https://doi.org/10.1177/0894439316666272>.

Cybula, G., Wieczorek, M. (2006). Co mogą zrobić rówieśnicy? - rola edukacji nieformalnej. Katowice: Metis, [online] <https://www.metis.pl/content/view/176/1>.

Davies, M., Cunningham, G. (1999). Adolescent Parasuicide in the Foyle Area. „Journal of Psychological Medicine", 16, 9-12.

Dębski, M. (2016). Nałogowe korzystanie z telefonów komórkowych. Gdańsk: Fundacja Dbam o Mój Zasięg.

Dooley, J. J., Pyżalski, J., Cross, D. (2009). Cyberbullying Versus Face-to-Face Bullying: A Theoretical and Conceptual Review. „Zeitschrift für Psychologie / Journal of Psychology”, 217 (4), 182-188.

Dylak, S. (2012). Szkoła w cyfrowym uścisku - z nadzieją nie tylko na igrzyska. „Studia Edukacyjne", 183-202.

Erjavec, K. (2014). Readers of Online News Comments: Why Do They Read Hate Speech Comments? „Annales: Series Historia et Sociologia”, 24 (3), 451-462.

European children. LSE, London: EU Kids Online.

Feliksiak, M. (2015). Dzieci i młodzież w internecie - korzystanie i zagrożenia z perspektywy opiekunów. Warszawa: CBOS.

Fineberg, N., Demetrovics, Z., Stein, D., loannidis, K., Potenza, M., Grünblatt, E., Chamberlain, S. (2018). Manifesto for a European Research Network into Problematic Usage of the Internet. „European Neuropsychopharmacology”. DOI:10.1016/j.euroneuro.2018.08.004.

FRSI (2018). Dołącz do mądrych cyfrowo. Warszawa: Fundacja Rozwoju Społeczeństwa Informacyjnego, [online] <http://frsi.org.pl/dolacz-do-madrych-cyfrowych/>.

Gaffney, H., Farrington, D., Espelage, D., Ttofi, M. (2018). Are Cyberbullying Intervention and Prevention Programs Effective? A Systematic and Metaanalytical Review. „Aggression and Violent Behavior", 1-20.

Gámez-Guadix, M., de Santisteban, P., Resett, S. (2017). Sexting among Spanish Adolescents: Prevalence and Personality Profiles. „Psicothema”, 29 (1), 29-34, [online] <https://doi. org/10.7334/psicothema2016.222>.

Garandeau, C., Cillessen, A. (2006). From Indirect Aggression to Invisible Aggression: A Conceptual View on Bullying and Peer Group Manipulation. „Aggression and Violent Behavior”, 11, 641-654.

Garett, R., Lord, L. R., Young, S. D. (2016). Associations between Social Media and Cyberbullying: A Review of the Literature. „Mental Health”, 2, 46. DOI:10.21037/mhealth.2016.12.01.

Global Dignity (2016). Wilki i owce w Internecie, czyli raport na temat hejtu wśród młodzieży. Warszawa: Global Dignity Poland.

Głomb, K. (red.) (2018). Smartfon w szkole jako narzędzie edukacyjne ucznia. Warszawa: Stowarzyszenie Miasta w Internecie. 
Hawdon, J., Oksanen, A., Räsänen, P. (2017). Exposure to Online Hate in Four Nations: A CrossNational Consideration. „Deviant Behavior”, 38 (3), 254-266, [online] <https://doi.org/10 .1080/01639625.2016.1196985>.

Hinduja, S., Patchin, J. W. (2009). Bullying Beyond the Schoolyard: Preventing and Responding to Cyberbullying. Sage Publications (Corwin Press).

Hojnacki, L., Kowalczuk, M., Kudlek, K., Polak, M., Szlagor, P. (2011). Mobilna edukacja M-Learning, czyli (r)ewolucja w nauczaniu. Warszawa: Wydawnictwo Think Global.

Ito, M., Horst, H. A., Bittanti, M., Boyd, D., Becky Stephenson, H., Lange, P. G., Pascoe, C. J., Robinson, L. (2008). Living and Learning with New Media: Summary of Findings from the Digital Youth Project In The John D. and Catherine T. MacArthur Foundation Reports on Digital Media and Learning. Cambridge: MIT Press.

Jarosz, E. (2018). Postawy wobec przemocy w wychowaniu - czy dobra zmiana? Warszawa: Biuro Rzecznika Praw Dziecka.

Jaskulska, S., Poleszak, W., (2015). Peer Exclusion. [W:] J. Pyżalski (red.), Educational and Socio-Cultural Competences of Contemporary Teachers. Selected Issues. Łódź: the Q studio, 130-148.

Jaszczak, A. (2008). Cyberedukacja seksualna i cyberseks młodzieży. [W:] B. Szmigielska (red.), Całe życie w sieci. Kraków: Wydawnictwo Uniwersytetu Jagiellońskiego.

Jiang, X., Zhou, Y. (2012). Dissecting Android Malware: Characterization and Evolution, [w:] 2012 IEEE Symposium on Security and Privacy. San Francisco: IEEE, 95-109.

Joinson, A. N. (2009). Przyczyny i skutki rozhamowanego zachowania w Internecie. [W:] W. J. Paluchowski (red.), Internet a psychologia. Możliwości i zagrożenia. Warszawa: PWN SA.

Kalka, J. (2016). Szkolne relacje. [W:] Młodzież 2016. Warszawa: Krajowe Biuro ds. Przeciwdziałania Narkomanii.

Karaca, A., Akkus, D., Sener, D. K. (2018). Peer Education from the Perspective of Peer Educators. „Journal of Child \& Adolescent Substance Abuse”, 27 (2), 76-85.

Kąkol, M., Jankowski-Lorek, M., Abramczuk, K., Wierzbicki, A., Catasta, M. (2013). On the Subjectivity and Bias of Web Content Credibility Evaluations. [W:] Proceedings of the 22nd International Conference on World Wide Web. New York: ACM, 1131-1136.

Kirwil, L. (2010). Polskie dzieci w Internecie. Zagrożenia i bezpieczeństwo na tle danych dla UE. Wstępny raport z badań EU Kids Online przeprowadzonych wśród dzieci w wieku 9-16 lat i ich rodziców. Warszawa: Szkoła Wyższa Psychologii Społecznej.

Kirwil, L. (2011). Polskie dzieci w Internecie. Zagrożenia i bezpieczeństwo - część 2. Częściowy raport z badań EU Kids Online II przeprowadzonych wśród dzieci w wieku 9-16 lat i ich rodziców. Warszawa: SWPS - EU Kids Online PL.

Kirwil, L., Garmendia, M., Garitaonandia, C., Martinez Fernandez, G. (2009). Parental Mediation. [W:] S. Livingstone, L. Haddon (red.), Kids Online: Opportunities and Risks for Children. Bristol: The Policy Press, 199-215. 
Klement, M., Klementová, S. (2016). The Current Degree of Implementation of Ict in the Life of Schools. ICERI2016 Proceedings. DOI:10.21125/iceri.2016.0370.

Klus-Stańska, D. (2013). Cyfrowi tubylcy w szkole cyfrowych imigrantów, czyli awatar w świecie Ptysia i Balbinki. „Problemy Wczesnej Edukacji”, 4 (23), 6-14.

Kochenderfer, B. J., Ladd, G. W. (1996). Peer Victimization: Cause or Consequence of School Maladjustment? „Child Developement”, 67 (4), 1305-1317.

Koehler, M. J., Mishra, P. (2009). What is Technological Pedagogical Content Knowledge? „Contemporary Issues in Technology and Teacher Education” (CITE Journal), 9 (1), 60-70.

Korkmaz, M., Esen, B. K. (2013). The Development and Evaluation of a Peer-Training Program for Elementary School Students Teaching Secure Internet Use. „Education”, 133 (3), 261.

Korkmaz, M., Kiran-Esen, B. (2012). The Effects of Peer-Training about Secure Internet Use on Adolescents. „Turkish Psychological Counseling \& Guidance Journal”, 4 (38), 180-187.

Kowalski, R. M., Morgan, C. A., Limber, S. E. (2012). Traditional Bullying as a Potential Warning Sign of Cyberbullying. „School Psychology International”, 33, 505-519.

Kraut, R., Kiesler, S., Boneva, B., Cummings, J., Helgeson, V., Crawford, A. (2002). Internet Paradox Revisited. „Journal of Social Issues”, 58, 49-74.

Kubicka, D. (2007). Seksualność w mediach i jej wpływ na intymne życie młodzieży. [W:] D. Kubicka, A. Kołodziejczyk (red.), Psychologia wpływu mediów. Kraków: Impuls.

Lange, R., Osiecki, J. (2014). Raport z badań. Nastolatki wobec Internetu. Warszawa: NASK.

Lapidot-Lefler, N., Barak, A. (2012). Effects of Anonymity, Invisibility, and lack of Eye-Contact on Toxic Online Disinhibition. „Computers in Human Behavior”, 28, 434-443.

Lim, M. S. C., Agius, P. A., Carrotte, E. R., Vella, A. M., Hellard, M. E. (2017). Young Australians' Use of Pornography and Associations with Sexual Risk Behaviours. „Australian \& New Zealand Journal of Public Health", 41 (4), 438-443, [online] <https://doi.org/10.1111/17536405.12678>.

Livingstone, S. (2003). Children's Use of the Internet: Reflections on the Emerging Research Agenda. „New Media \& Society”, 5 (2), 147-166.

Livingstone, S. (2012). Critical Reflections on the Benefits of ICT in Education. „Oxford Review of Education", 38 (1), 9-24.

Livingstone, S., Bober, M. (2004). UK Children Go Online: Surveying the Experiences for Young People and Their Parents. London: LSE.

Livingstone, S., Byrne, J. (2018). Parenting in the Digital Age. The Challenges of Parental Responsibility in Comparative Perspective. [W:] G. Mascheroni, C. Ponte, A. Jorge (red.), Digital Parenting. The Challenges for Families in the Digital Age. Göteborg: Nordicom, 19-30.

Livingstone, S., Davidson, J., Bryce, J. (2017). Children's Online Activities, Risks and Safety. London: London School of Economics and Political Science.

Livingstone, S., Haddon, L., Görzig, A., Ólafsson, K. (2011). EU Kids Online: Final Report. EU Kids Online. London: London School of Economics \& Political Science. 
Livingstone, S., Haddon, L., Görzig, A., Ólafsson, K. (2011). Risks and Safety on the Internet: The Perspective of European Children. Full FINDINGS. LSE, London: EU Kids Online.

Livingstone, S., Helsper, E. J. (2007). Taking Risks When Communicating on the internet: The Role of Offline Social-Psychological Factors in Young People's Vulnerability to Online Risks. „Information, Communication \& Society”, 10 (5), 619-643.

Livingstone, S., Helsper, E. J. (2008). Parental Mediation of Children's Internet Use. „Journal of Broadcasting \& Electronic Media", 52 (4), 581-599.

Livingstone, S., Mascheroni, G., Staksrud, E. (2015). Developing a Framework for Researching Children's Online Risks and Opportunities in Europe. London: London School of Economics \& Political Science.

Livingstone, S., Mascheroni, G., Staksrud, E. (2018). European Research on Children's Internet Use: Assessing the Past and Anticipating the Future. „New Media and Society”, 20 (3), 1103-1122.

Livingstone, S., Ólafsson, K., Helsper, E. J., Lupiáñez, V. F., Veltri, G. A., Folkvord, F. (2017). Maximizing Opportunities and Minimizing Risks for Children Online: The Role of Digital Skills in Emerging Strategies of Parental Mediation. „Journal of Communication”, 67 (1), 82-105.

Lobe, B., Livingstone, S., Ólafsson, K., Vodeb, H. (2011). Cross-National Comparison of Risks and Safety on the Internet: Initial Analysis from the EU Kids Online Survey of European Children.

Macháčková, H., Cerna, A., Sevcikova, A., Dedkova, L., Daneback, K. (2013). Effectiveness of Coping Strategies for Victims of Cyberbullying. „Cyberpsychology: Journal of Psychosocial Research on Cyberspace", 7 (3), article 5, [online] <http://dx.doi.org/10.5817/CP2013-3-5>.

Macháčková, H., Dedkova, L., Sevcikova, A., Cerna, A. (2013). Bystanders' Support of Cyberbullied Schoolmates. „Journal of Community \& Applied Social Psychology”, 23 (1), 25-36.

Makaruk, K. (2013). Korzystanie z portali społecznościowych przez młodzież. Wyniki badania EU NET ADB. „Dziecko Krzywdzone. Teoria, Badania, Praktyka”, 12 (1), 69-79.

Makaruk, K., Włodarczyk, J., Michalski, P. (2017). Kontakt dzieci i młodzieży z pornografią. Warszawa: Fundacja Dajemy Dzieciom Siłę.

Malak, M. Z. (2018). Internet Addiction and Cognitive Behavioral Therapy. Cognitive Behavioral Therapy and Clinical Applications. DOI:10.5772/intechopen.71277.

Mascheroni, G., Cuman, A. (2014). Net Children Go Mobile. Milano: Educatt.

Mascheroni, G., Ólafsson, K. (2014). Net Children Go Mobile: Risks and Opportunities. Milano: Educatt. [2 edycja].

Mauersberger, A. (2017). GemeinsamLärmmachen! BuB: Forum Bibliothek Und Information, $69(2 / 3), 122-127$.

McKenna, K. Y. A., Green, A. S., Gleason, M. E. J. (2002). Relationship Formation on the Internet: What's the Big Attraction? „Journal of Social Issues”, 58, 9-31.

Middaugh, E., Schofield Clark, L., Ballard, P. J. (2017). Digital Media, Participatory Politics and Positive Youth Development. „Pediatrics”, 140, 127-131, [online] <https://doi. org/10.1542/peds.2016-1758Q>.

\section{8}


Mishna, F., Cook, C., Saini, M., Wu, M. J., MacFadden, R. (2009). Interventions for Children, Youth, and Parents to Prevent and Reduce Cyber Abuse. "Campbell Systematic Reviews", 2.

Moawad, G. E. N. A., Ebrahem, G. G. S. (2016). The Relationship between Use of Technology and Parent-Adolescents Social Relationship. „Journal of Education and Practice”, 7 (14), 168-178.

Mróz, A., Solecki, R. (2017). Postawy rodziców wobec aktywności nastolatków w internecie w percepcji uczniów (Attitudes of Parents toward online Activity of Teenagers in Perception of Students). „E-mentor”, 4 (71).

Naezer, M. (2018). From Risky Behaviour to Sexy Adventures: Reconceptualising Young People's Online Sexual Activities. „Culture, Health \& Sexuality”, 20 (6), 715-729, [online] <https:// doi.org/10.1080/13691058.2017.1372632>.

NIK (2017). Zapobieganie i przeciwdziałanie cyberprzemocy wśród dzieci i młodzieży. Kielce: Najwyższa Izba Kontroli - Delegatura w Kielcach.

Nixon, C. L. (2014). Current Perspectives: The Impact of Cyberbullying on Adolescent Health. „Adolescent Health and Medical Therapy”, 5, 143-158.

OECD (2015). Students, Computers and Learning. Making the Connection, [online] <http:// www.oecd.org/education/students-computers-andlearning-9789264239555-en.htm>.

Olenik-Shemesh, D., Heiman, T., Eden, S. (2012). Cyberbullying Victimization in Adolescence: Relationships with Loneliness and Depressive Mood. „Emotional and Behavioural Difficulties", 3-4, 361-374.

Olweus, D. (2013). School Bullying: Development and Some Important Challenges. „Annual Review of Clinical Psychology", 9, 751-780.

Olweus, D., Limber, S. (2018). Some Problems with Cyberbullying Research. „Current Opinion in Psychology", 19, 139-143.

Orange (2016). Rodzice i dzieci wobec zagrożeń dzieci w Internecie. Warszawa: Fundacja Orange.

Patchin, J. W., Hinduja, S. (2018). Sextortion Among Adolescents: Results From a National Survey of U.S. Youth. Sexual Abuse, [online] <https://doi.org/10.1177/1079063218800469>.

Pawłowska, B., Zygo, M., Potembska, E., Kapka-Skrzypczak, L., Dreher, P., Kędzierski, Z. (2015). Prevalence of Internet Addiction and Risk of Developing Addiction as Exemplified by a Group of Polish Adolescents from Urban and Rural Areas. „Annals of Agricultural and Environmental Medicine", 22 (1), 129-136. DOI:10.5604/12321966.1141382.

Penberthy, J. K., Wartella, J. A., Vaughan, M. (2010). Cognitive Behavioral Therapy for Addiction. „Addiction Medicine”, 729-750. DOI:10.1007/978-1-4419-0338-9_36.

Pew Research Center (2018). Teens, Social Media \& Technology 2018, [online] <http://www. pewinternet.org/2018/05/31/teens-social-media-technology-2018/>.

Plebańska, M. (red.) (2017). Polska szkoła w dobie cyfryzacji. Diagnoza 2017, [online] <https:// www.librus.pl/2017/10/12/polecamy-raport-z-najwiekszego-badania-cyfryzacji-szkol/>. 
Plichta, P. (2017). Socjalizacja i wychowanie dzieci i młodzieży z niepełnosprawnością intelektualną w erze cyfrowej. Kraków: Wydawnictwo A. Marszałek.

Plichta, P., Pyżalski, J., Barlińska, J. (2018). Cyberprzemoc a kreowanie własnego wizerunku w Internecie - co w ich mechanizmach zmienia niepełnosprawność młodych dorosłych osób? „Interdyscyplinarne Konteksty Pedagogiki Specjalnej”, 20, 101-122.

Polskie Bractwo Kawalerów Gutenberga (2013). Nowe media w polskiej szkole. Wyniki badań. Warszawa: Polskie Bractwo Kawalerów Gutenberga.

Potyrała, K. (2017). iEdukacja. Synergia nowych mediów i dydaktyki. Ewolucja - antynomie konteksty. DOI:10.24917/9788380840522.

Przybylski, A. K., Nash, V. (2018). Internet Filtering and Adolescent Exposure to Online Sexual Material. „Cyberpsychology, Behavior, and Social Networking”, 21 (7), 405-410, [online] <https://doi.org/10.1089/cyber.2017.0466>.

Pyżalski, J. (2011). Agresja elektroniczna wśród dzieci i młodzieży. Sopot: GWP.

Pyżalski, J. (2012). Agresja elektroniczna i cyberbullying jako nowe ryzykowne zachowania młodzieży. Kraków: Oficyna Wydawnicza „Impuls”.

Pyżalski, J. (2013). Rodzina i szkoła a przeciwdziałanie zaangażowaniu młodych ludzi w ryzykowne zachowania online. „Dziecko Krzywdzone. Teoria, Badania, Praktyka”, 12 (1), 99-109.

Pyżalski, J. (2016). Od paradygmatu ryzyka do paradygmatu szans - prospołeczne i prorozwojowe używanie internetu przez dzieci i młodzież. [W:] M. Tanaś (red.), Nastolatki wobec internetu. Warszawa: NASK.

Pyżalski, J. (2017a). Jasna strona - partycypacja i zaangażowanie dzieci i młodzieży w korzystne rozwojowo i prospołeczne działania. „Dziecko Krzywdzone. Teoria, Badania, Praktyka”, 16 (1), 288-303.

Pyżalski, J. (red.) (2017b). Małe dzieci w świecie technologii informacyjno-komunikacyjnych: pomiędzy utopijnymi szansami a przesadzonymi zagrożeniami. Łódź, Wydawnictwo Eter.

Pyżalski, J. (2017c). Młodzi internauci a edukacja medialna - dlaczego musimy odejść od miejsca, w którym jesteśmy. [W:] W. Skrzydlewski (red.), Kultura, Edukacja, Technologia Kształcenia. Poznań: Wydawnictwo Naukowe UAM.

Pyżalski, J. (2018). Przeciwdziałanie przemocy rówieśniczej w szkole - krytyczny przegląd stosowanych rozwiązań. „Dziecko Krzywdzone. Teoria, Badania, Praktyka”, 17 (1), 30-45.

Raskauskas, J. (2010). Text-bullying: Associations with Traditional Bullying and Depression Among New Zealand Adolescents. „Journal of School Violence”, 9, 74-97.

Raskauskas, J., Huynh, A. (2015). The Process of Coping with Cyberbullying: A Systematic Review. „Aggression and Violent Behavior”, 23, 118-125.

Rębisz, S., Sikora, I., Smoleń-Rębisz, K. (2016). Poczucie samotności a poziom uzależnienia od internetu wśród adolescentów. „Edukacja - Technika - Informatyka”, 15 (1), 90-98. DOI:10.15584/eti.2016.1.13.

Rice, E., Craddock, J., Hemler, M., Rusow, J., Plant, A., Montoya, J., Kordic, T. (2018). Associations Between Sexting Behaviors and Sexual Behaviors Among Mobile Phone-Owning Teens 
in Los Angeles. „Child Development”, 89 (1), 110-117, [online] <https://doi.org/10.1111/ cdev.12837>.

Salmivalli, C. (1999). Participant Approach to School Bullying: Implication for Interventions. „Journal of Adolescence”, 22, 453-459.

Salmivalli, C., Karhunen, J., Lagerspetz, K. M. (1996). How Do the Victims Respond to Bullying? „Aggressive Behavior”, 22, 99-109.

Salmivalli, C., Lagerspetz, K., Bjorkqvist, K., Osterman, K., Kaukiainen, A. (1996). Bullying as a Group Process: Participant Roles and Their Relations to Social Status within the Group. „Aggressive Behavior”, 22, 1-15.

Salmivalli, C., Voeten, M., Poskiparta, E. (2011). Bystanders Matter: Associations Between Reinforcing, Defending, and the Frequency of Bullying Behavior in Classrooms. „Journal of Clinical Child \& Adolescent Psychology", 40 (5), 668-676.

Selwyn, N. (2010). Looking Beyond Learning: Notes Towards the Critical Study of Educational Technology. „Journal of Computer Assisted Learning”, 26 (1), 65-73.

Smith, P. K. (2010). Cyberbullying: the European Perspective. [W:] J. A. Mora-Merchán, T. Jäger (red.), Cyberbullying: A Cross-National Comparison. Landau: Verlag Empirische Pädagogik.

Solecki, R. (2017). Aktywność młodzieży w cyberprzestrzeni. Warszawa-Milanówek: Oficyna Wydawnicza Von Velke.

Spies Shapiro, L. A., Margolin, G. (2014). Growing up Wired: Social Networking Sites and Adolescent Psychosocial Development. „Clinical Child and Family Psychology Review”, 17 (1), $1-18$.

Spišák, S. (2016). „Everywhere They Say That It's Harmful but They Don't Say How, so l'm Asking Here”: Young People, Pornography and Negotiations with Notions of Risk and Harm. „Sex Education: Sexuality, Society and Learning", 16 (2), 130-142.

Staksrud, E., Livingstone, S. (2009). Children and Online Risk: Powerless Victims or Resourceful Participants? „Information, Communication \& Society”, 12 (3), 364-387.

Stanley, N., Barter, C., Wood, M., Aghtaie, N., Larkins, C., Lanau, A., Överlien, C. (2018). Pornography, Sexual Coercion and Abuse and Sexting in Young People's Intimate Relationships: A European Study. „Journal of Interpersonal Violence”, 33 (19), 2919-2944, [online] <https://doi.org/10.1177/0886260516633204>.

Statista (2018). Most Popular Social Networks Worldwide as of October 2018, [online] <https:// www.statista.com/statistics/272014/global-social-networks-ranked-by-number-of-users/>.

Stošić, L., Stošić, I. (2015). Perceptions of Teachers Regarding the Implementation of the Internet in Education. "Computers in Human Behavior”, 53, 462-468. DOI:10.1016/j. chb.2015.07.027.

Suler, J. (2004). The Online Disinhibition Effect. „Cyberpsychology \& Behavior”, 7, 321-326.

Szymczak, E. (2015). Hejting jako przykład współczesnego zagrożenia w przestrzeni społecznej. „Studia Edukacyjne”, 37, 91-107. DOI:10.14746/se.2015.37.7. 
Tanaś, M., Kamieniecki, W., Bochenek, M., Wrońska, A., Lange, R., Fila M., Loba, B. (2017). Nastolatki 3.0. Wyniki ogólnopolskiego badania nastolatków w szkołach. Warszawa: NASK.

Tokunaga, R. S. (2010). Following You Home from School: A Critical Review and Synthesis of Research on Cyberbullying Victimization. "Computers in Human Behavior”, 26, 277-287.

Tomczyk, Ł. (2015). Vzděláváníseniorů v oblastinovýchmédií. Praha: AIVD.

Tomczyk, Ł. (2017). Cyberbullying in 2010 and 2015 - A perspective on the Changes in the Phenomenon Among Adolescents in Poland in the Context of Preventive Action. "Children and Youth Services Review", 75, 50-60. DOI:10.1016/j.childyouth.2017.02.017.

Tomczyk, Ł., Kopecký, K. (2016). Children and Youth Safety on the Internet: Experiences from Czech Republic and Poland. „Telematics and Informatics”, 33 (3), 822-833. DOI:10.1016/j. tele.2015.12.003.

Tomczyk, Ł., Selmanagic-Lizde, E. (2018). Fear of Missing Out (FOMO) Among Youth in Bosnia and Herzegovina - Scale and Selected Mechanisms. "Children and Youth Services Review”, 88, 541-549. DOI:10.1016/j.childyouth.2018.03.048.

Tomczyk, Ł., Szotkowski, R., Kopecký, K. (2017). Zachowania ryzykowne dzieci i młodzieży związane z udostępnianiem i odbiorem materiałów o charakterze seksualnym - wybrane wyniki badań czeskiego Centrum Prewencji Ryzyka Wirtualnej Komunikacji z lat 2010-2017. „Dziecko Krzywdzone. Teoria, Badania, Praktyka”, 16 (3).

Tsao, J. (1996). Compensatory Media Use: An Exploration of Two Paradigms. „Communication Studies", 47, 89-199.

Tsitsika, A. K., Tzavela, E. C., Janikian, M., Ólafsson, K., Iordache, A., Schoenmakers, T. M., Richardson, C. (2014). Online Social Networking in Adolescence: Patterns of Use in Six European Countries and Links with Psychosocial Functioning. „The Journal Of Adolescent Health”: Official Publication Of The Society For Adolescent Medicine, 55 (1), 141-147, [online] < https:// doi.org/10.1016/j.jadohealth.2013.11.010>.

Ustawa Prawo oświatowe (2017). Ustawa z dnia 11 stycznia 2017 r. Prawo oświatowe (Dz. U. z 2017 poz. 59.).

Valkenburg, P. M., Peter, J., Schouten, A. P. (2006). Friend Networking Sites and Their Relationship to Adolescents' Well Being and Social Self-Esteem. „Cyberpsychology and Behavior”, 9, 584-590.

Valkenburg, P., Piotrowski, J., Hermanns, J., de Leeuw, R. (2013). Developing and Validating the Perceived Parental Media Mediation Scale: A Self-Determination Perspective. „Human Communication Research", 39 (4), 445-469.

Wespieser, K., \& National Foundation for Educational Research (NFER) (England). (2015). Young People and E-Safety: The Results of the 2015 London Grid for Learning E-Safety Survey. National Foundation for Educational Research.

Węgrzynowska, J. (2016). Dzieci doświadczające przemocy rówieśniczej. „Dziecko Krzywdzone. Teoria, Badania, Praktyka", 15 (1) 9-26. 
Wisniewski, P., Ghosh, A. K., Xu, H., Rosson, M. B., Carroll, J. M. (2017). Parental Control vs. Teen Self-Regulation: Is There a Middle Ground for Mobile Online Safety? [W:] Proceedings of the 2017 ACM Conference on Computer Supported Cooperative Work and Social Computing. New York: ACM, 51-69.

Wojtasik, Ł. (2015). Seksting. [W:] A. Wrzesień-Gandolfo (red.), Bezpieczeństwo dzieci online. Warszawa: NASK.

Young, K. S. (2017). The Evolution of Internet Addiction. „Addictive Behaviors”, 64, 229-230. DOI:10.1016/j.addbeh.2015.05.016.

Ziemba, E. (2013). The Holistic and Systems Approach to the Sustainable Information Society. „Journal of Computer Information Systems”, 54 (1), 106-116. DOI:10.1080/08874417.20 13.11645676.

Zilka, G. C. (2017). Awareness of eSafety and Potential Online Dangers among Children and Teenagers. „Journal of Information Technology Education: Research”, 16, 319-338.

Zych, I., Ortega-Ruiz, R., Del Rey, R. (2015). Systematic Review of Theoretical Studies on Bullying and Cyberbullying: Facts, Knowledge, Prevention and Intervention. „Aggression and Violent Behavior", 23, 1-21.6. 



\section{Noty 0 autorach}

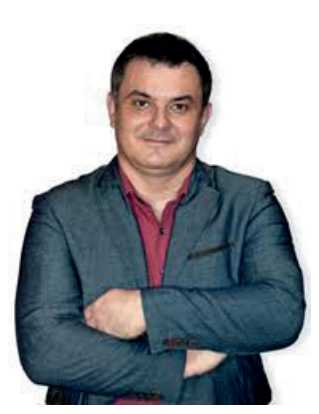

Jacek Pyżalski - kierownik badania EU Kids Online Polska 2018, pedagog, prof. nadzw. na Wydziale Studiów Edukacyjnych Uniwersytetu im. Adama Mickiewicza w Poznaniu (Zakład Specjalnych Potrzeb Edukacyjnych). Pomysłodawca, uczestnik i koordynator ok. 55 krajowych i międzynarodowych projektów badawczych (w tym wielu dotyczących agresji elektronicznej, edukacji medialnej i związków korzystania internetu z edukacją i wychowaniem). Autor licznych publikacji, w tym pierwszej monografii na rynku polskim dotyczącej agresji elektronicznej Agresja elektroniczna wśród dzieci i młodzieży (2010) oraz książki Agresja elektroniczna i cyberbullying jako nowe ryzykowne zachowania młodzieży. Koordynator oraz wykonawca 60 międzynarodowych i krajowych projektów badawczych dotyczących agresji elektronicznej. Członek międzynarodowych konsorcjów naukowych koordynowanych przez Europejską Fundację Nauki, skupionych wokół ważnych problemów edukacyjnych: cyberbullyingu (COST IS0801), satysfakcji z wizerunku (COST IS1210) oraz COST CA16207 dotyczącej problematycznego używania internetu i jego konsekwncji. 


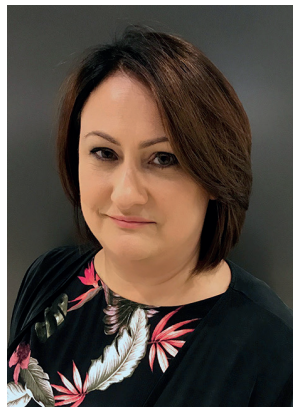

Aldona Zdrodowska - badaczka w Laboratorium Interaktywnych Technologii Ośrodka Przetwarzania Informacji - Państwowego Instytutu Badawczego. Zainteresowania naukowe ogniskuje przede wszystkim wokół społecznych i psychologicznych aspektów korzystania z nowych technologii i mediów. Brała udział w realizacji krajowych i międzynarodowych projektów badawczych, m.in. jako ekspert dla Komisji Europejskiej, stypendystka NCN. Od 2008 roku uczestniczy w pracach polskiego zespołu EU Kids Online. Ukończyła studia na kierunku Społeczna Psychologia Informatyki i Komunikacji (Uniwersytet SWPS), ze specjalizacjami w zakresie interakcji człowiek - komputer, psychologii mediów oraz psychologii twórczości. Doktorantka w Instytucie Psychologii Polskiej Akademii Nauk; prowadzi zajęcia akademickie na SWPS Uniwersytecie Humanistycznospołecznym, a także wykłady i warsztaty dla dzieci, rodziców i nauczycieli, dotyczące bezpiecznego korzystania z internetu.

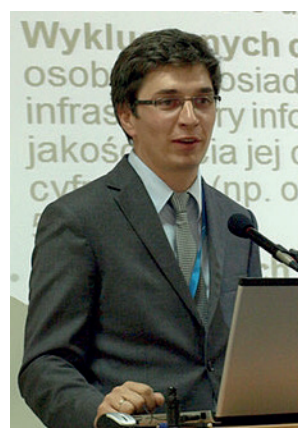

kukasz Tomczyk - adiunkt w Instytucie Nauk o Wychowaniu Uniwersytetu Pedagogicznego im. Komisji Edukacji Narodowej w Krakowie, inżynier informatyki, doktor filozofii PhDr. - specjalność edukacja dorosłych (Uniwersytet Karola w Pradze), doktor nauk społecznych w zakresie pedagogiki (Uniwersytet Pedagogiczny). Recenzent podręczników szkolnych w Ministerstwie Edukacji Narodowej w zakresie technologii informacyjnej. Autor i współautor 4 monografii, ponad 100 recenzowanych artykułów, współredaktor 13 monografii wydanych w Polsce i za granica. Prelegent na ponad 60 konferencjach naukowych. Ekspert w zakresie: pedagogiki mediów, andragogiki, geragogiki. Był odpowiedzialny za realizację 16 projektów badawczych. Stypendysta programu Mundus Penta oraz laureat prestiżowego stypendium Ministra Nauki i Szkolnictwa Wyższego dla wybitnych młodych naukowców w okresie 2018-2020. Członek międzynarodowej sieci COST Action CA16207 European Network for Problematic Usage of the Internet.

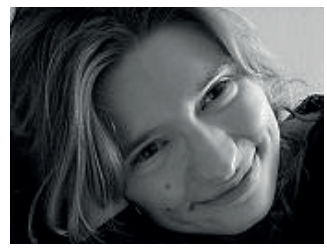

Katarzyna Abramczuk - analityczka danych i statystyczka w OPI Państwowym Instytucie Badawczym oraz adiunktka w Instytucie Socjologii Uniwersytetu Warszawskiego. Specjalizuje się w badaniach interdyscyplinarnych nad podejmowaniem decyzji. Interesuje się modelowaniem formalnym w naukach społecznych, psychologią poznawczą, ekonomią behawioralną, metodyką nauczania matematyki oraz społecznymi aspektami nowych technologii. Była stypendystką Freie Universität Berlin, Universidad del Pais Vasco i Max Planck Institut für Bildungsforschung. Obroniła doktorat z zakresu socjologii matematycznej na Uniwersytecie Warszawskim. Pracowała w Instytucie Nauk Politycznych PAN. Uczestniczyła w kilku projektach badawczych. Autorka szeregu publikacji. Obecnie kieruje merytoryczną częścią międzynarodowego projektu edukacyjnego ACTISS. 
